\section{Pacific Northwest}

National Laboratory

Operated by Battelle for the

U.S. Department of Energy

\title{
Treatability Test Plan for 300 Area Uranium Stabilization through Polyphosphate Injection
}

\author{
V.R. Vermeul \\ M.D. Williams \\ B.G. Fritz \\ R.D. Mackley \\ D.P. Mendoza \\ D.R. Newcomer \\ M.L. Rockhold \\ B.A. Williams \\ D.M. Wellman
}

May 2007

Prepared for the U.S. Department of Energy under Contract DE-AC05-76RL01830 


\title{
DISCLAIMER
}

This report was prepared as an account of work sponsored by an agency of the United States Government. Neither the United States Government nor any agency thereof, nor Battelle Memorial Institute, nor any of their employees, makes any warranty, express or implied, or assumes any legal liability or responsibility for the accuracy, completeness, or usefulness of any information, apparatus, product, or process disclosed, or represents that its use would not infringe privately owned rights. Reference herein to any specific commercial product, process, or service by trade name, trademark, manufacturer, or otherwise does not necessarily constitute or imply its endorsement, recommendation, or favoring by the United States Government or any agency thereof, or Battelle Memorial Institute. The views and opinions of authors expressed herein do not necessarily state or reflect those of the United States Government or any agency thereof.

\author{
PACIFIC NORTHWEST NATIONAL LABORATORY \\ operated by \\ BATTELLE \\ for the \\ UNITED STATES DEPARTMENT OF ENERGY \\ under Contract DE-AC05-76RL01830
}

Printed in the United States of America

Available to DOE and DOE contractors from the

Office of Scientific and Technical Information,

P.O. Box 62, Oak Ridge, TN 37831-0062;

ph: (865) 576-8401

fax: $(865) 576-5728$

email: reports@adonis.osti.gov

\author{
Available to the public from the National Technical Information Service, \\ U.S. Department of Commerce, 5285 Port Royal Rd., Springfield, VA 22161 \\ ph: (800) 553-6847 \\ fax: (703) 605-6900 \\ email: orders@ntis.fedworld.gov \\ online ordering: http://www.ntis.gov/ordering.htm
}

This document was printed on recycled paper.

$(9 / 2003)$ 


\title{
Treatability Test Plan for 300 Area Uranium Stabilization through Polyphosphate Injection
}

\author{
V.R. Vermeul (Task Lead) \\ M.D. Williams \\ B.G. Fritz \\ R.D. Mackley \\ D.P. Mendoza \\ D.R. Newcomer \\ M.L. Rockhold \\ B.A. Williams \\ D.M. Wellman (Principal Investigator)
}

May 2007

Prepared for

the U.S. Department of Energy

under Contract DE-AC05-76RL01830

Pacific Northwest National Laboratory

Richland, Washington 99352 


\section{Summary}

For fiscal year 2006, the United States Congress authorized \$10 million dollars to Hanford for "... analyzing contaminant migration to the Columbia River, and for the introduction of new technology approaches to solving contamination migration issues." These funds are administered through the U.S. Department of Energy Office of Environmental Management (specifically, EM-22). After a peer review and selection process, nine projects were selected to meet the objectives of the appropriation. As part of this effort, Pacific Northwest National Laboratory (PNNL) will perform bench- and field-scale treatability testing designed to evaluate the efficacy of using polyphosphate injections to reduced uranium concentrations in the groundwater to meet drinking water standards $(30 \mu \mathrm{g} / \mathrm{L})$ in situ. This technology works by forming phosphate minerals (autunite and apatite) in the aquifer that directly sequester the existing aqueous uranium in autunite minerals and precipitates apatite minerals for sorption and long-term treatment of uranium migrating into the treatment zone, thus reducing current and future aqueous uranium concentrations. Polyphosphate injection was selected for testing based on technology screening as part of the 300-FF-5 Phase III Feasibility Study for treatment of uranium in the 300 Area.

The overall objectives of the treatability test include the following:

- Conduct a polyphosphate injection to evaluate reduction of aqueous uranium concentrations and to determine the longevity of the treatment zone.

- Demonstrate field-scale application of polyphosphate injections to identify implementation challenges and evaluate whether a full-scale deployment is feasible.

- Determine the number of wells, reagent concentrations, volumes, injection rates, operational strategy, and longevity for polyphosphate injections to remediate uranium such that costs for larger-scale application can be effectively estimated.

Key design parameters associated with these objectives include the radius of influence of the polyphosphate amendment injections, injection concentrations, types and amount of phosphate minerals formed, reduction of aqueous uranium concentrations, and long-term treatment capacity of the amended zone.

This treatability test plan reports results from bench-scale treatability studies and site-specific characterization activities; it also outlines the approach adopted to evaluate the polyphosphate technology at field scale. The general treatability testing approach consists of initial site characterization and setup, a polyphosphate injection test, and post-treatment performance assessment. In addition to these activities, bench-scale studies with site sediment were conducted to develop an effective chemical formulation for the polyphosphate amendments and evaluate the transport properties of these amendments under site conditions. The polyphosphate injection will be conducted in three separate phases: (1) polyphosphate amendment injection, (2) calcium chloride injection, and (3) another polyphosphate amendment injection. Following this series of injections, post-treatment performance will be evaluated from analysis of aqueous samples collected from site wells and column experiments conducted on sediment samples collected from the treatment zone to determine the distribution of autunite and apatite mineral phase content created during the treatment. In addition to remediating a portion of the plume, the data from this test will provide valuable information for designing a full-scale remediation of uranium in the aquifer at the 300 Area of the Hanford Site. 


\section{Acronyms and Abbreviations}

ARAR

BTC

BWTF

CERCLA

COD

DO

DOE

DOE-RL

Ecology

EPA

ERDF

FAP

IC

ICP

IDW

ISE

LED

LFI

MCL

MS

NEPA

OCP

OES

ORP

PNNL

PV

PVC

QA

QAPP

RCRA

SBMS

SEM-EDS

TDS

UV

XRD

$\mathrm{XRF}$ applicable or relevant and appropriate requirement(s)

breakthrough curves

Buried Waste Test Facility

Comprehensive Environmental Response, Compensation, and Liability Act

chemical oxygen demand

dissolved oxygen

U.S. Department of Energy

U.S. Department of Energy, Richland Operations Office

Washington State Department of Ecology

U.S. Environmental Protection Agency

Environmental Restoration Disposal Facility

fluorapatite

ion chromatography

inductively coupled plasma

investigation-derived waste

ion selective electrode

light-emitting diode

limited field investigation

maximum contaminant level

mass spectrometer

National Environmental Policy Act of 1969

octacalcium phosphate

optical emission spectrometry

oxidation-reduction potential

Pacific Northwest National Laboratory

pore volume

polyvinyl chloride

quality assurance

Quality Assurance Project Plan

Resource Conservation and Recovery Act

Standards-Based Management System

scanning electron microscopy-energy dispersive spectroscopy

total dissolved solids

ultraviolet

$\mathrm{x}$-ray diffraction

$\mathrm{x}$-ray fluorescence 


\section{Contents}

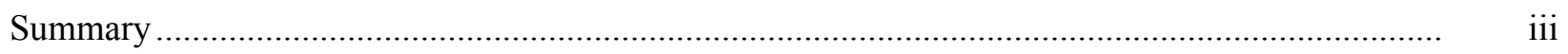

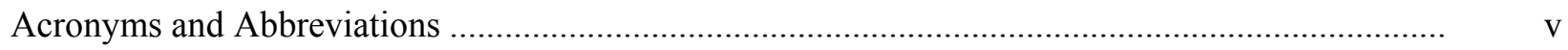

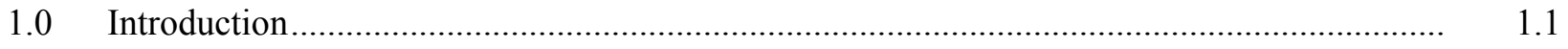

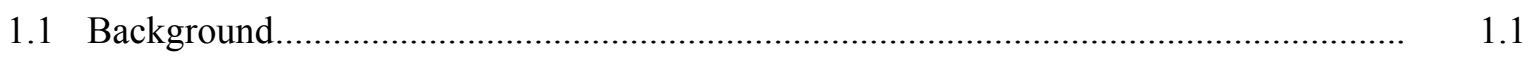

1.1.1 300 Area Uranium Plume ….................................................................... 1.1

1.1.2 300-FF-5 Limited Field Investigation........................................................... 1.7

1.1.3 Public Involvement in 300 Area Groundwater Decisions ................................ 1.7

1.1.4 Polyphosphate Technology Description ...................................................... 1.8

1.1.5 Selection of the Treatability Test Site........................................................ 1.10

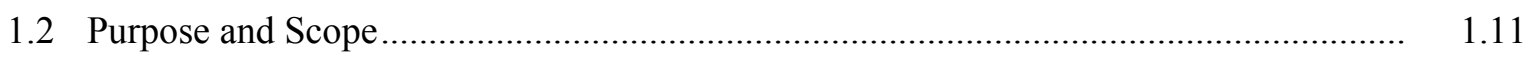

2.0 Bench-Scale Studies and Treatment Technology Description............................................ 2.1

2.1 Polyphosphate Remediation Technology ................................................................ 2.1

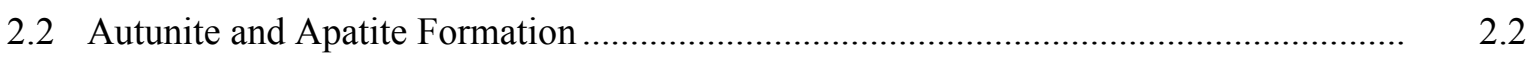

2.2.1 Column Experiments ............................................................................ 2.9

2.3 Polyphosphate Amendment ............................................................................... 2.19

3.0 Performance and Data Quality Objectives ................................................................. 3.1

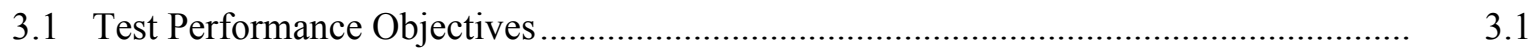

3.2 Data Quality Objectives................................................................................... 3.1

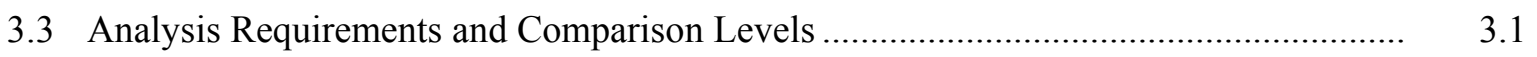

4.0 Compliance with Applicable or Relevant and Appropriate Requirements ........................... 4.1

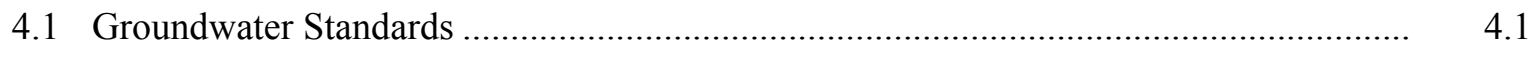

4.2 Columbia River Protection Standards .................................................................... 4.2

4.3 Cultural and Ecological Resource Protection Standards ............................................ 4.2

4.4 Waste and Wastewater Management Standards .......................................................... 4.3

$5.0 \quad$ Conceptual Design and Site Setup ............................................................................. 5.1

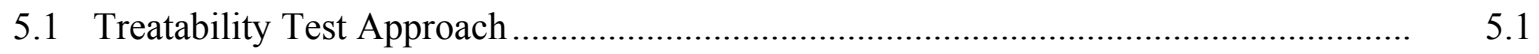

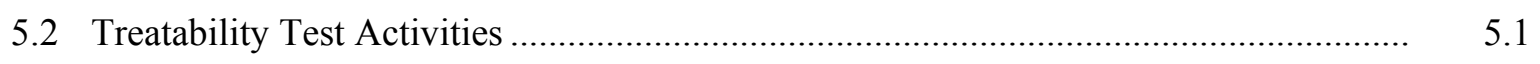

5.3 Setup and Instrumentation of Field Test Site ...................................................... 5.4

5.3.1 Site Location and Utilities ........................................................................ 5.4

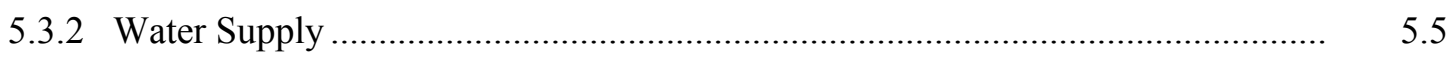

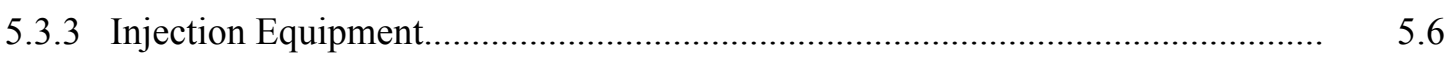

5.3.4 Monitoring Equipment............................................................................ 5.6

5.3.5 Analytical Measurements ....................................................................... 5.9

5.3.6 Water-Level/Pressure Response Measurement .............................................. $\quad 5.9$ 


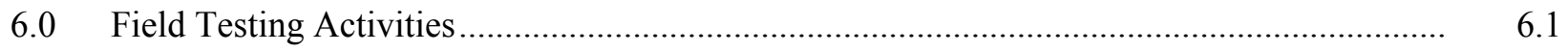

6.1 Well Installation and Geohydrologic Characterization ............................................. 6.1

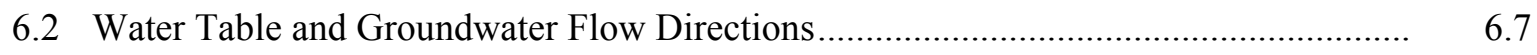

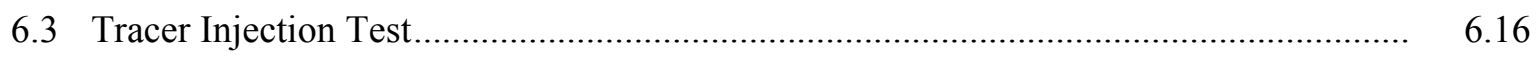

6.3.1 Tracer Test Description ........................................................................ 6.16

6.3.2 Tracer Test Results and Discussion .......................................................... 6.18

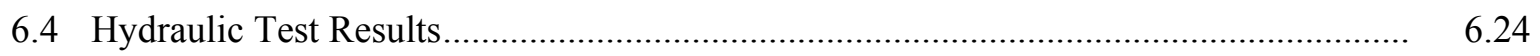

6.4.1 River Response Correction ..................................................................... $\quad 6.24$

6.4.2 Hydraulic Test Analysis .......................................................................... 6.27

6.4.3 Hydraulic Gradient Analysis ................................................................... 6.31

6.4.4 Additional Site Characterization Activities ................................................. 6.32

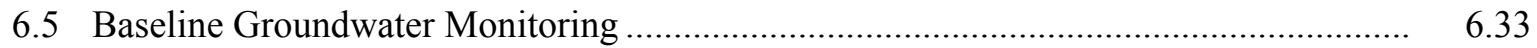

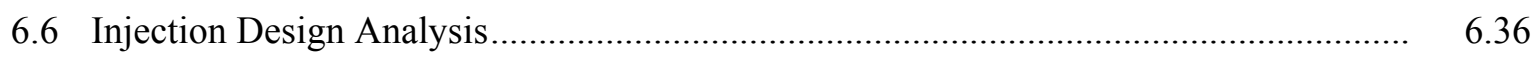

6.6.1 Injection Volume and Rates................................................................. 6.36

6.6.2 Treatability Test Numerical Model Description ............................................. $\quad 6.40$

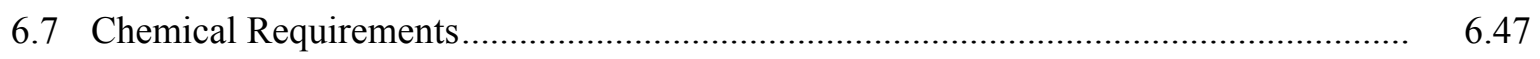

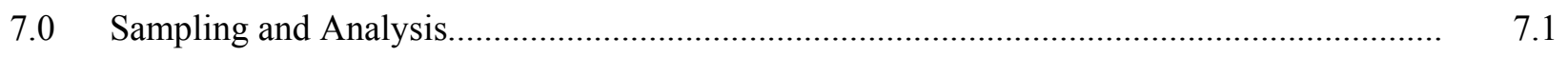

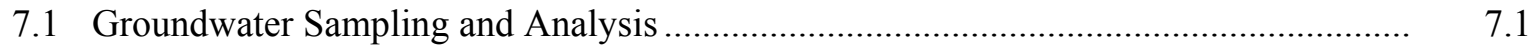

7.2 Sediment Core Sample Collection ........................................................................

7.3 Post Treatment Sediment Analysis ........................................................................... 7.5

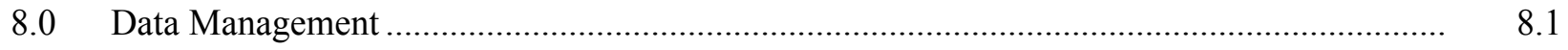

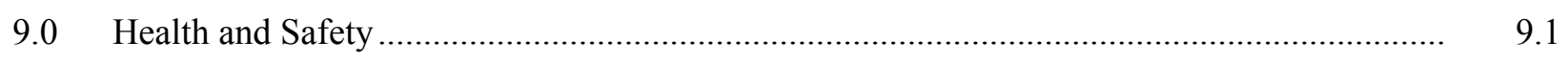

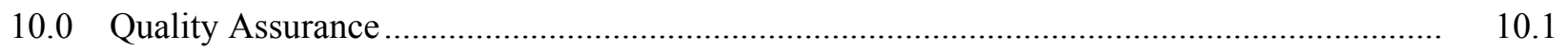

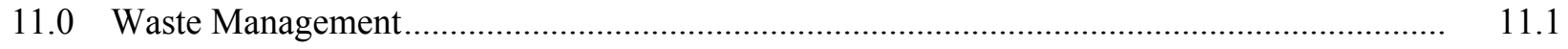

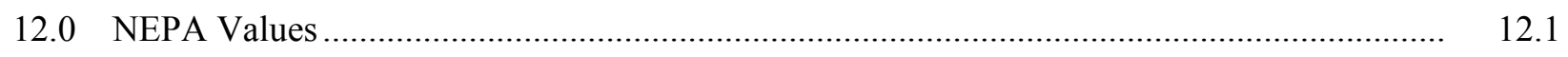

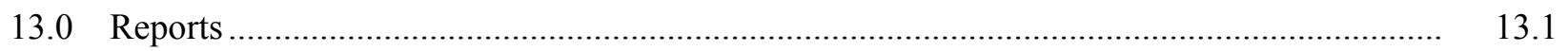

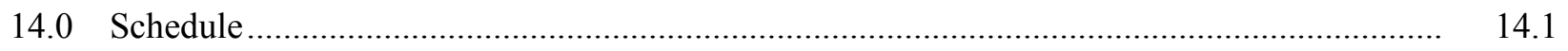

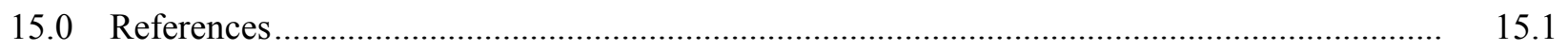

\section{Figures}

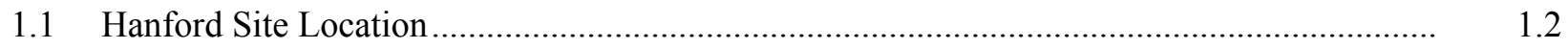

1.2300 Area Detail Map Showing Uranium Plume in December 2005 and Test Site

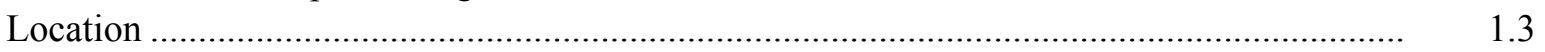

1.3 Detailed Location of Polyphosphate Treatability Test Site .................................................. 1.4

1.4300 Area Detail Map Showing Uranium Plume in June 2006 ............................................ 1.5

1.5 Hydrogeologic Column Depicting the Hydrogeology of the 300 Area .................................. 1.8

1.6 Composite Borehole Log for Well 399-1-23 .................................................................... 1.9 
2.1 Schematic Depicting the Step-Wise Hydrolysis of Sodium Tripolyphosphate ..................... 2.1

2.2 Hydrolysis Rate of Polyphosphate Molecules as a Function of $\mathrm{pH}$...................................... 2.1

2.3 Percent Removal of Calcium and Phosphorus as a Function of Calcium to Phosphorus Ratio.

2.4 Representative Photo of Sediment Sectioned from the Effluent End of Column 1 Illustrating the Visual Identification of Uranium-Phosphate Under Shortwave UV Radiation

2.5 Photo Showing Disperse Precipitation of Calcium-Phosphate Throughout Column 1; Discrete Precipitation of Calcium-Phosphate within Column 4

2.6 Graphs Depicting Aqueous Uranium Concentrations from Columns Saturated with $1,000 \mu \mathrm{g} / \mathrm{L}$ Uranium as a Function of the Number of Pore Volumes of Polyphosphate Remedy Displaced through Columns 11, 12, 13, and 14

2.7 Photos of Columns Sections Taken Under Shortwave UV Radiation

2.8 Representative Plot Depicting the Removal of Phosphorus via Sorption and Precipitations Reactions

2.9 Graphs Depicting Aqueous Uranium Concentrations from Columns Saturated with $1,000 \mu \mathrm{g} / \mathrm{L}$ Uranium as a Function of the Number of Pore Volumes of Polyphosphate Remedy Displaced Through Columns 15, 16, 17, and 18.

2.10 Breakthrough Curves for Sodium Ortho-, Pyro-, Tripolyphosphate, Calcium, the Phosphorus Amendment Formulation as Mixed, and the Phosphorus Amendment Formulation $\mathrm{pH}$ Adjusted to $\sim 7$

5.1 Site Layout Centered Around the Injection and Monitoring Wells

5.2 Schematic of the Injection Manifold with the Make-Up Water and all Other Necessary Components

5.3 Schematic Drawing of the Groundwater Sample Acquisition System .....

5.4 Schematic Layout of Pressure Sensor Network

6.1 Initial Well Layout for Polyphosphate Treatability Test Site Showing Well Construction.....

6.2 Well Layout of Additional Downgradient Monitoring Wells at Polyphosphate Treatability Test Site

6.3 Map Showing Transect Location for Figure 6.4 (A-A') .

6.4 Hydrogeologic Cross Section A-A'

6.5 Elevation Contour Map of the Hanford/Ringold Contact Boundary, 300-FF-5 Operable Unit

6.6 Columbia River Stage from the 300-Area Gauging Station for 2006

6.7 Water Table and Uranium Concentrations in Upper Part of Unconfined Aquifer Beneath 300 Area, December 2005

6.8 Water Table and Uranium Concentrations in Upper Part of Unconfined Aquifer Beneath 300 Area, June 2006

6.9 Original 300 Area Water-Level Monitoring Network - High River Stage Example .............. 
6.11 Hydraulic Gradient Directions for the First Half of 2006 Calculated from 300 Area Automated Water-Level Network for Well Cluster 399-1-2, 399-1-7, and 399-1-12

6.12 Hydraulic Gradient Directions for the Second Half of 2006 Calculated from 300 Area Automated Water-Level Network for Well Cluster 399-1-2, 399-1-7, and 399-1-12

6.13 Expanded 300 Area Water-Level Monitoring Network - Low River Stage Example ............

6.14 Flow Rate, Duration, and Total Injection Volume for Bromide Tracer Test at Polyphosphate Treatability Test Site on December 13, 2006

6.15 Bromide Concentrations for the Tracer Injection Stream During the Injection Period of the Test and for Several Days Following the Test, as Measured in the Injection Well.......

6.16 Breakthrough Curves Showing Bromide Concentrations through Time for FullyScreened Wells Within the Targeted Injection Volume: 399-1-26, 399-1-29, 399-1-30, and 399-1-31

6.17 Breakthrough Curves Showing Bromide Concentrations through Time for Wells Within the Targeted Injection Volume that are Screened in Only the Upper or Lower Zones of the Aquifer: 399-1-24, 399-1-25, 399-1-27, and 399-1-28

6.18 Breakthrough Curves (BTC) Showing Bromide Concentrations through Time for Downgradient Wells a) 399-1-32 and b) 399-1-7.

6.19 Relation Between Changing River Stage and Time-Lagged and Attenuated Response in Well 399-1-23 for Several Weeks Prior to and Following Tracer Injection Test.....

6.20 Plot Showing an Example of Water Elevations Before and After Correction for RiverStage Fluctuations for Well 399-1-23 During Background Water Levels Several Days Prior to the Injection Test..

6.21 Plot Showing Changing River Conditions During the Period of Pressure Buildup During the Injection Test for the Monitoring Well 399-1-24

6.22 Corrected and Uncorrected Pressure Buildup Data for the Monitoring Well 399-1-26

6.23 Neuman Type-Curve Analysis of Pressure Buildup Data at Well 399-1-26.....

6.24 Neuman Type-Curve Analysis of Pressure Buildup Data at Well 399-1-24 ..........................

6.25 Neuman Type-Curve Analysis of Pressure Buildup Data at Well 399-1-25 .........................

6.26 Neuman Type-Curve Analysis of Pressure Buildup Data at Well 399-1-31 .....

6.27 Example Slug Test Responses at Three Wells Completed Over the Entire Hanford Formation Thickness.

6.28 Post-Tracer Test Background Water-Level Gradients for Well-Well Combinations Stepping Progressively Down Gradient

6.29 Tracer Breakthrough Curves during Injection Period of the December 13, 2006, Bromide Tracer Test

6.30 Tracer Breakthrough Curves during Injection Period of the December 13, 2006, Bromide Tracer Test

6.31 Analytic Solution for Tracer Arrivals at Different Radial Distances Using Estimated June Conditions 
6.32 Plan View of Polyphosphate Treatability Test STOMP Model Domain and Finite

Difference Grid .

6.33 Hydrostratigraphic Zonations in Polyphosphate Site Model at $105 \mathrm{~m}$ Elevation.

6.34 Hydrostratigraphic Zonations in Polyphosphate Site Model at 102.5 m Elevation

6.35 Preliminary Results of Polyphosphate Site Model of Bromide Tracer Test

6.36 Preliminary Results of Polyphosphate Site Model of Bromide Tracer Test

6.46

14.1 Schedule of Field Test Activities

\section{Tables}

2.1 Possible Sources and Associated Solubility for Polyphosphate Amendment .......................... 2.3

2.2 Experimental Batch Conditions for Polyphosphate Amendment Optimization ...................... 2.4

2.3 Down-Selected Experimental Batch Conditions for Polyphosphate Amendment

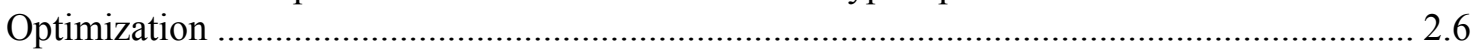

2.4 Experimental Parameters for Polyphosphate Amendment Optimization Column Tests .......... $\quad 2.10$

2.5 Transport Parameters Determined by Direct Measurement or from Laboratory Derived Breakthrough Curves on the $<2 \mathrm{~mm}$ Sediment Fraction.

2.6 Field Transport Parameters Calculated from Laboratory Derived Transport Parameters......... $\quad 2.19$

2.7 Pilot-Scale Field Test Amendment Formulation................................................................... 2.20

3.1 Uranium Stabilization through Polyphosphate Injection Key Decisions ................................ 3.2

$5.1 \quad$ Field Parameter Monitoring Electrode Specifications ..................................................... 5.9

6.1 Polyphosphate Treatability Well Identification and Borehole Information............................. 6.2

6.2 Physical Property Data for Bulk Sediment Samples from Well 399-1-23 ............................ 6.8

6.3 Summary of Polyphosphate Treatability Test Site Tracer Injection Test ............................... $\quad 6.16$

6.4 Bromide Tracer Injection Arrival Times and Porosity Results for Targeted Injection Volume Monitoring Wells

6.5 Summary of Parameters Used to Estimate Hydraulic Conductivity Between Injection Well 399-1-23 and Downgradient Well 399-1-32 for Main Body of Tracer.

6.6 Pressure Buildup Summary for Monitoring Wells during the 2006 Bromide Tracer Injection Test

6.7 Anion Concentration Results from the First Baseline Sampling Event ................................ 6.34

6.8 Trace Metals Concentration Results by from the first Baseline Sampling Event ................... 6.34

6.9 Cation Concentration Results from the first Baseline Sampling Event ................................ 6.35

6.10 Field Parameters Measured in Samples Collected During the First Baseline Sampling Event

6.11 Estimated Volumes for Tracer Arrivals for Bromide Tracer Test conducted in December 2006 .

6.12 Scaled Tracer Arrivals for Wells at the Treatability Test Site to a 7.6-m Radius.....

6.39 
7.1 Groundwater Chemistry Sampling Requirements .........................................................

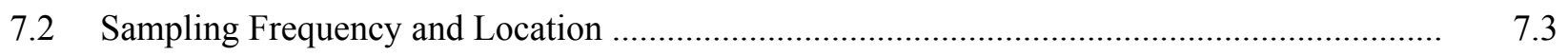

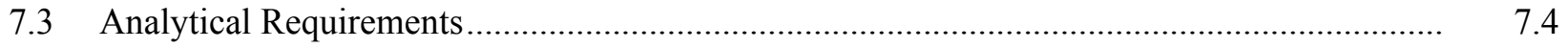

7.4 Semi-Selective Chemical Extraction Procedure ................................................................

11.1 Spill Kits and Spill Control Equipment …...................................................................... 11.1 


\subsection{Introduction}

This treatability test plan describes the proposed field testing for uranium stabilization through polyphosphate injection for treatment of the 300 Area uranium groundwater plume at the Hanford Site (see Figures 1.1 and 1.2). The objective of the polyphosphate treatability test is to evaluate the efficacy of using polyphosphate injections to reduce uranium concentrations in the groundwater to meet drinking water standards $(30 \mu \mathrm{g} / \mathrm{L})$ in situ. This technology works by forming phosphate minerals (autunite and apatite) in the aquifer that directly sequester the existing aqueous uranium in autunite minerals and precipitates apatite minerals for sorption and long-term treatment of uranium migrating into the treatment zone, thus reducing current and future aqueous uranium concentrations (Wellman et al. 2005, 2006). Polyphosphate injection was selected for testing based on previous lab scale investigations. In situ treatment of uranium contamination is consistent with the results of technology screening to identify a viable remedial action alternative for uranium in 300 Area groundwater, as part of the 300-FF-5 Phase III Feasibility Study (DOE 2005).

The field site for the polyphosphate treatability test, which is located around well 399-1-23, was selected from four detailed characterization wells installed in FY06 as part of the 300-Area limited field investigation (Williams et al. 2007). The polyphosphate treatability test site is comprised of a single injection well (399-1-23) surrounded by a network of monitoring wells within the targeted injection volume and downgradient monitoring wells (see Figures 1.2 and 1.3). The monitoring wells were installed in November and December 2006 as part of the initial site characterization as described in Vermeul et al. (2006). Additional downgradient monitoring wells, which are being installed to facilitate monitoring of amendment/tracer plume drift under the groundwater flow regime expected during spring high river stage conditions, are scheduled for installation in May 2007.

\subsection{Background}

This section provides background information on the 300 Area uranium plume and the evolution of activities that will ultimately lead to a remedial action decision. In 1996, a record of decision (EPA 1996a) identified the following interim actions for remediation of the uranium contaminant plume beneath the site:

- Continued groundwater monitoring to determine how contaminant conditions may change with time.

- Institutional controls to limit the use of groundwater.

The interim action results have determined that uranium concentrations in the groundwater plume have been generally declining, but still persist at concentrations above the drinking water standard (remediation goal). Therefore, re-evaluation of the remedy for uranium contamination is necessary because the rate of decrease in uranium concentrations is significantly different than the rate of decrease expected and used as a basis for the remedy selection in the current record of decision.

\subsubsection{Area Uranium Plume}

A groundwater plume containing uranium from past-practice discharges of liquid waste associated with nuclear fuel fabrication activities has persisted beneath the Hanford Site 300 Area for many years (see Figures 1.2 and 1.4). As indicated through comparison of these two figures, during high river stage 


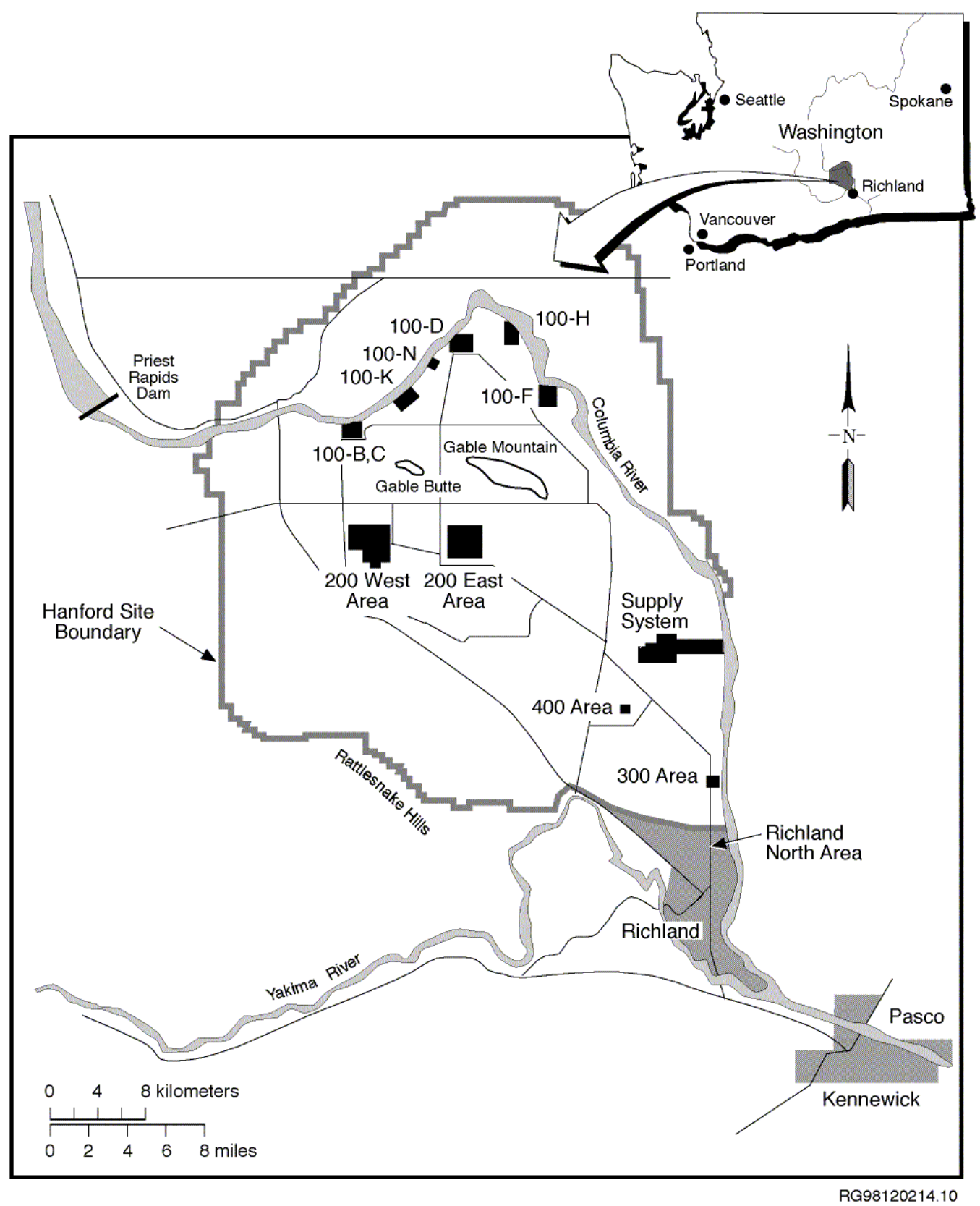

Figure 1.1. Hanford Site Location 


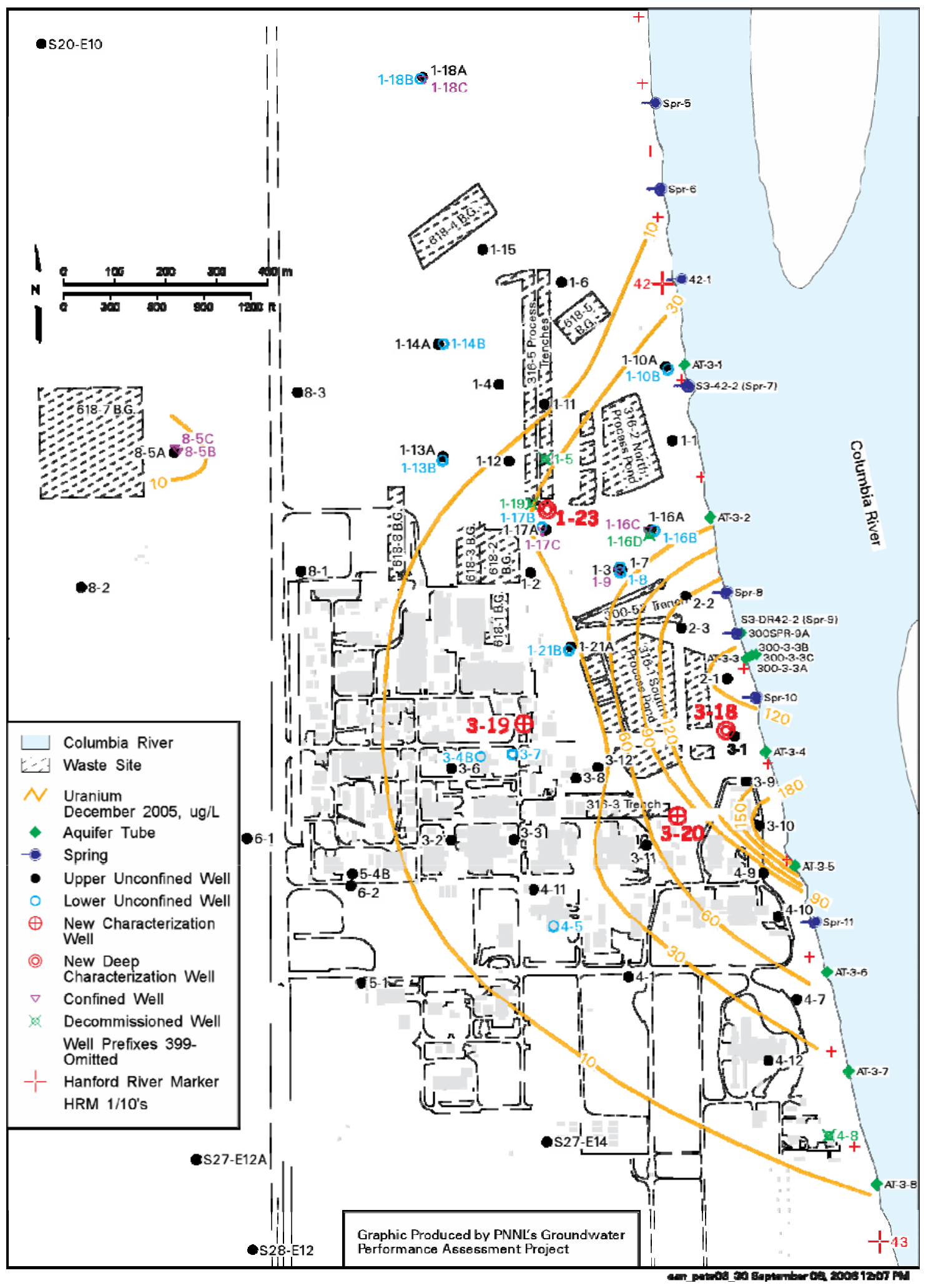

Figure 1.2. 300 Area Detail Map Showing Uranium Plume in December 2005 and Test Site Location (around well 399-1-23) 


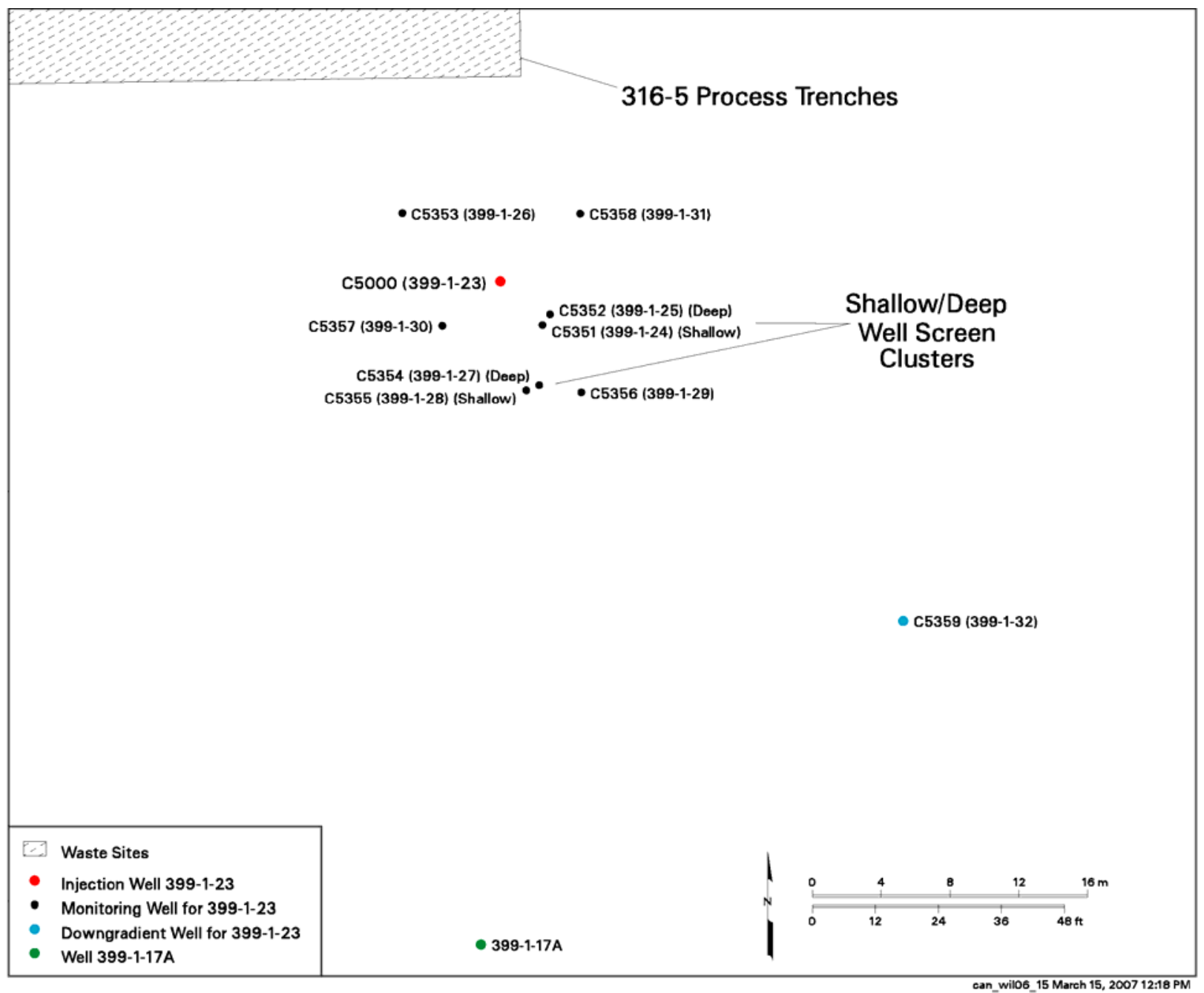

Figure 1.3. Detailed Location of Polyphosphate Treatability Test Site 


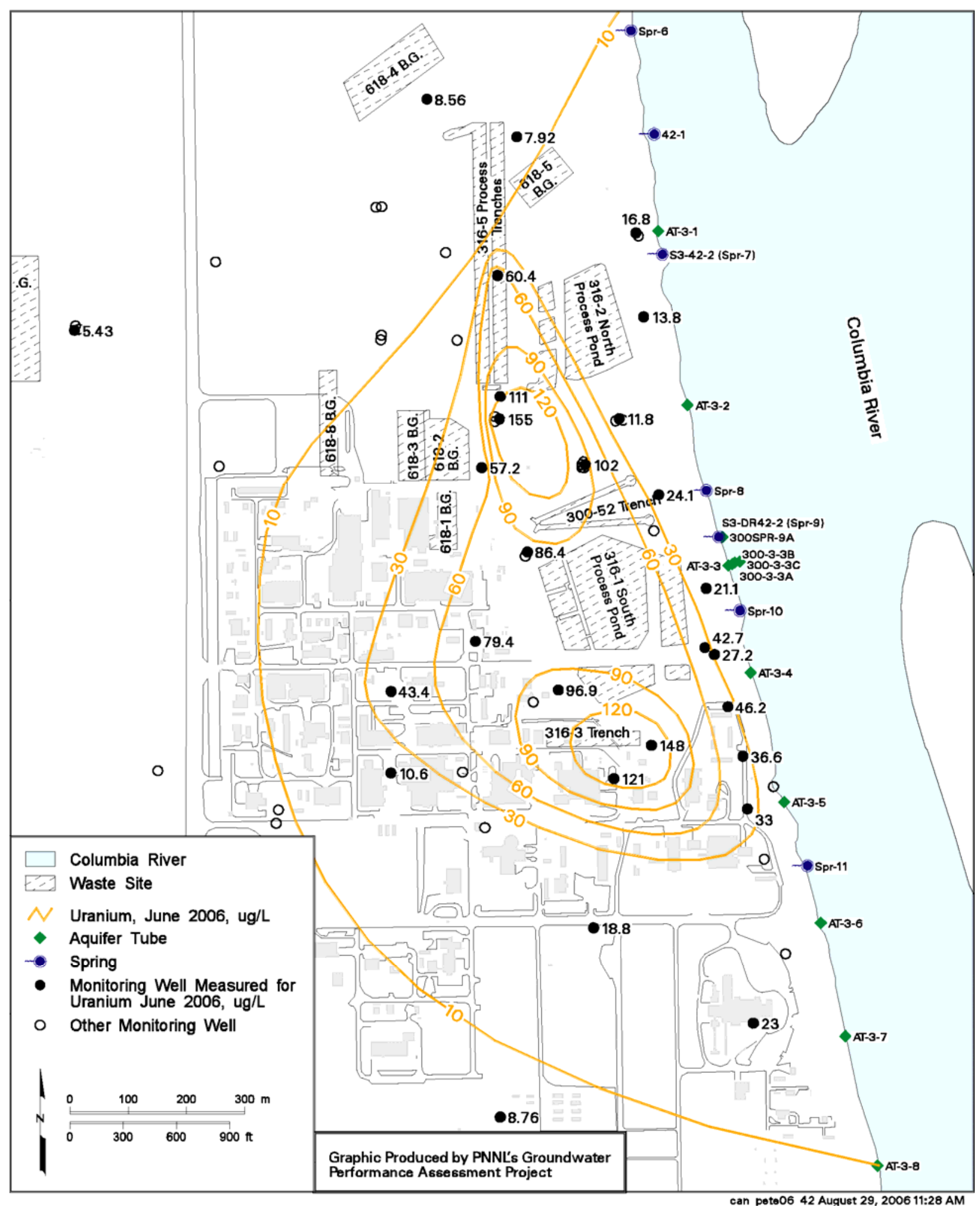

Figure 1.4. 300 Area Detail Map Showing Uranium Plume in June 2006 
conditions in June 2006, uranium concentrations were elevated in localized areas farther inland than indicated during December 2005. It is thought that these increases in uranium concentration are associated with contamination remaining in the deep vadose zone and "smear zone." The polyphosphate treatability test site is located near one of the two delineated deep vadose sources. The persistence of this plume is enigmatic for several reasons, including (1) discharges containing uranium-bearing effluent to ground disposal sites ended in the mid-1980s; (2) contaminated soil associated with these waste sites was removed during the 1990s, with backfilling complete by early 2004; and (3) the aquifer is comprised of highly transmissive fluvial sediment, suggesting rapid movement of groundwater. Also, a water supply well located within the plume has been in operation since 1980, with no observable effect on the plume. The current conceptual site model assumes that re-supply of the plume is occurring, with continuing release from the vadose zone beneath waste sites, the capillary fringe zone, and possibly from aquifer solids, as source candidates (Peterson et al. 2005).

A remedial investigation conducted in the early 1990s, along with an expedited response action to remove contaminated soil from the most recently used disposal site, led to a 1996 record of decision (EPA 1996a) for interim remedial action that involved continued groundwater monitoring and institution controls on the use of groundwater. Characterization of natural features and processes that would lead to attenuation of the contamination is part of the interim action, which continues. A computer simulation of the plume during the initial remedial investigation led to a prediction that concentrations would decrease to the proposed drinking water standard $(20 \mu \mathrm{g} / \mathrm{L}$ in 1993) in 3 to 10 years from 1993, assuming no re-supply of uranium to the plume (DOE 1995). This predicted response has not been observed in monitoring well trend data.

Maximum concentrations in the plume are currently less than $250 \mu \mathrm{g} / \mathrm{L}$, with mode values ranging from 30 to $90 \mu \mathrm{g} / \mathrm{L}$. The plume ( $>30 \mu \mathrm{g} / \mathrm{L})$ currently covers an area of $\sim 0.4 \mathrm{~km}^{2}\left(0.15 \mathrm{mi}^{2}\right)$. Assuming a representative thickness of the contaminated layer of $3.3 \mathrm{~m}(10.8 \mathrm{ft})$ and $27 \%$ porosity, the volume of contaminated groundwater is $\sim 350,000 \mathrm{~m}^{3}\left(460,000 \mathrm{yd}^{3}\right)$ and the mass of dissolved uranium is $\sim 20 \mathrm{~kg}$ (44 lb) (Peterson et al. 2005). The length of Columbia River shoreline impacted is $\sim 1,500 \mathrm{~m}(4,900 \mathrm{ft})$. Uranium removal via a water supply well for the 331 Life Sciences Building is $\sim 21 \mathrm{~kg}$ (46 lb) per yr, based on monitoring data.

Principal investigations leading to the current conceptual site model for this plume include early work to describe the hydrogeology and groundwater contamination of the 300 Area (Lindberg and Bond 1979); detailed investigations to support RCRA requirements at the 300 Area Process Trenches (Schalla et al. 1988); and the initial remedial investigation under CERCLA for the 300-FF-5 groundwater operable unit (DOE 1995). More recently, detailed geochemical research involving uranium in 300 Area sediment has been conducted to support decisions associated with cleanup of surface waste sites (Serne et al. 2002) and the renewed feasibility study of potential remedial action alternatives for the plume (Zachara et al. 2005). The latter investigations, which were conducted under the DOE's science and technology research programs, included sampling the vadose zone beneath two major liquid waste disposal sites located near the proposed treatability test site (well 399-1-23). Samples from vertical profiles that spanned the base of the disposal site excavations down to the water table were collected, and subjected to intensive laboratory investigations to determine the geochemical and mobility characteristics of residual uranium in the lower vadose zone. 


\subsubsection{0-FF-5 Limited Field Investigation}

A limited field investigation (LFI) was conducted as part of the Phase III Feasibility Study (Williams et al. 2007) to reduce uncertainties in two aspects of the conceptual model for the uranium plume: (1) the vertical distribution of uranium in the vadose zone and uppermost aquifer at representative sites, with special emphasis on the interface between unsaturated and saturated conditions (i.e., the capillary fringe zone) and geochemical characteristics that influence the mobility of uranium, and (2) the vertical and lateral distribution of uranium throughout the mapped plume area where drinking water standards are exceeded (DOE 2006).

The LFI characterization included collecting continuous core samples and depth-discrete groundwater samples, geophysical logging, and conducting aquifer tests at four sites that are representative of various combinations of proximity to waste sites and to the river, and in various hydrogeologic environments (Figure 1.2). The entire LFI area of interest is defined by the extent of the uranium plume, i.e., the area where concentrations are above natural background levels (i.e., above $\sim 10 \mu \mathrm{g} / \mathrm{L}$ ). The extent and general shape of this area has not changed appreciably for many years (Peterson et al. 2005). The distribution pattern of the higher concentrations within this area varies significantly with time and is thought to be a consequence of liquid effluent disposal activities, source excavation activities, fluctuations in water-table elevations, and plume migration. Results from drilling and characterization in the four new wells showed that the highest groundwater and vadose concentration of uranium is in the two wells 399-1-23 (C5000) and 399-3-18 (C4999). Results from these wells are contained in Williams et al. (2007). All the new wells have been completed with 15-cm- (6-in.-) diameter casing and screens to support treatability testing; first routine sampling of these wells occurred in July 2006.

Based on this characterization effort, the 300 Area hydrogeologic conceptual model was updated. This interpretation adds to existing published knowledge and information reported previously by others (e.g., Lindberg and Bond 1979; Schalla et al. 1988; Swanson et al. 1992). The hydrogeologic column for the 300 Area is illustrated in Figure 1.5. Figure 1.6 shows the composite borehole log for LFI well 399-1-23 which is the injection well for the polyphosphate treatability study.

\subsubsection{Public Involvement in 300 Area Groundwater Decisions}

Over the past 4 years, several public workshops have been held to discuss remedial action alternatives and future land use options for the Hanford 300 Area:

1. June 2002 and May 2003: U.S. Environmental Protection Agency (EPA)-sponsored stakeholder workshops to discuss remedial action alternatives for the 300 Area uranium plume.

2. May 2004: U.S. Department of Energy (DOE) Science and Technology Program open meeting with contractors and the public - Conceptual Model Development and Reactive Transport Modeling for the 300 Area Uranium Plume.

3. August 2004: DOE Headquarters review and discussion of 300 Area uranium plume - Monitoring Optimization Technical Assistance Workshop.

4. May 2005: DOE-sponsored stakeholder workshop to receive public input on remedial actions and future land use for the 300 Area - 300 Area End States Public Workshop.

5. October 2005: DOE-sponsored stakeholder involvement workshop - 300-FF-5 Workshop and Tour: Progress of the Limited Field Investigation Supporting the Phase III Feasibility Study. 
Hanford Site - 300 Area

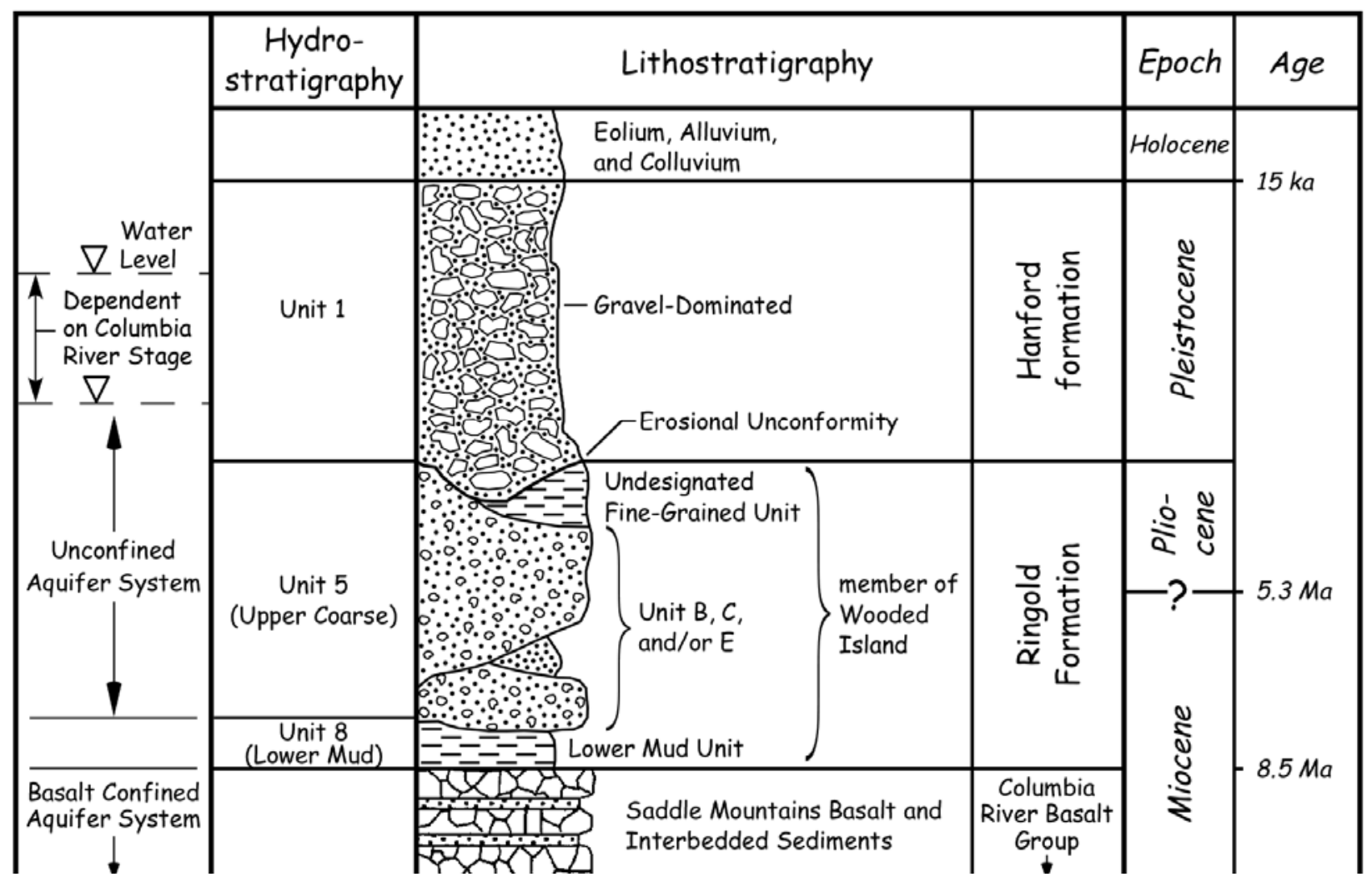

Figure 1.5. Hydrogeologic Column Depicting the Hydrogeology of the 300 Area (from Williams et al. 2007)

Input received from these workshops supports investigating remedial action technologies that are designed to reduce the concentrations of uranium in groundwater beneath the 300 Area such that the aquifer can be restored to its maximum beneficial use, i.e., as a resource for drinking water. Reducing concentrations in the aquifer will also reduce any potential risk to ecological receptors in the Columbia River.

\subsubsection{Polyphosphate Technology Description}

The use of soluble long-chain polyphosphate amendments has been demonstrated to delay the precipitation of phosphate phases (Wellman et al. 2006). Precipitation of phosphate minerals occurs when phosphate compounds degrade in water, due to hydrolysis, to yield the orthophosphate molecule $\left(\mathrm{PO}_{4}{ }^{3-}\right)$. The rate of the hydrolysis reaction that leads to production of orthophosphate is related to the length of the polyphosphate chain. Accordingly, use of a long-chain polyphosphate compound does not result in a drastic change in hydraulic conductivity of the target aquifer.

Injection of a sodium tripolyphosphate amendment into the uranium-bearing saturated porous media has been shown to immobilize uranium through the formation of an insoluble uranyl phosphate mineral, autunite $\left\{\mathrm{X}_{1-2}\left[\left(\mathrm{UO}_{2}\right)\left(\mathrm{PO}_{4}\right)\right]_{2-1} \bullet \mathrm{nH}_{2} \mathrm{O}\right\}$, where $\mathrm{X}$ is any monovalent or divalent cation. Because autunite sequesters uranium in the oxidized form, $\mathrm{U}^{6+}$, rather than forcing reduction to $\mathrm{U}^{4+}$, the possibility of re-oxidation and subsequent re-mobilization of uranium is negated. Release of uranium from the autunite 


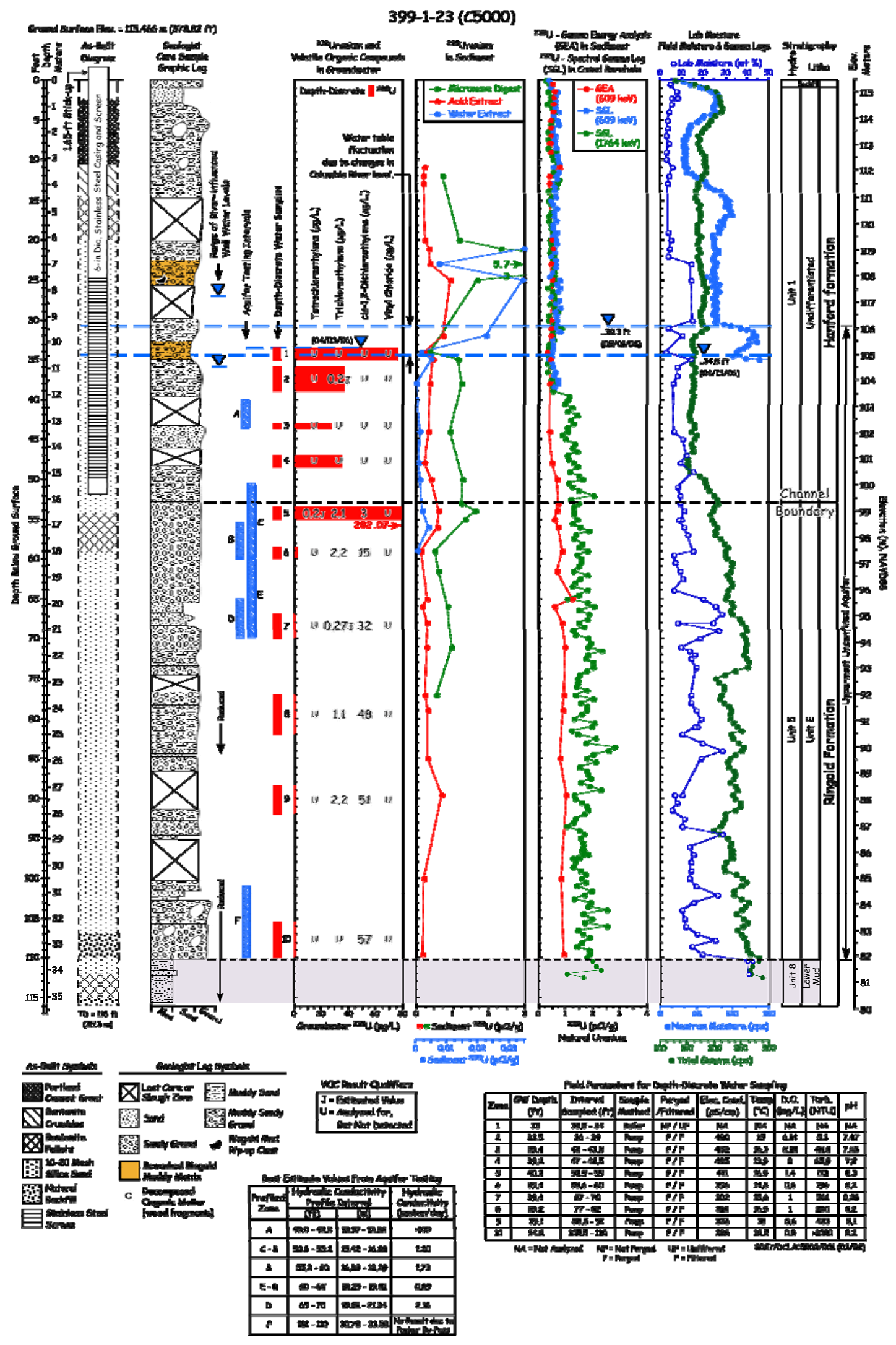

Figure 1.6. Composite Borehole Log for Well 399-1-23 (from Williams et al. 2007) 
structure may only occur through dissolution of the autunite structure. Extensive testing demonstrates the very low solubility and slow dissolution kinetics of autunite under conditions relevant to the Hanford subsurface (Wellman et al. 2006). In addition to autunite, excess phosphorous can result in apatite mineral formation, providing a long-term source of treatment capacity.

Research beginning in the mid-60s underscored the efficacy of utilizing calcium and/or lime to precipitate stable calcium-phosphate solid phases including apatite for direct removal of phosphate (Ferguson et al. 1970, 1973; Jenkins et al. 1971; Schmid and McKinney 1968). By complexing calcium and sorbing to mineral surfaces, polyphosphate compounds effectively enhancing the rate of calcium phosphate precipitation by reducing competing reactions, such as the formation of calcium carbonate, and "directing" calcium to participate in reactions resulting in calcium phosphate precipitation (Ferguson et al. 1973).

Fuller et al. (2003, 2002a) demonstrated the efficacy of hydroxyapatite for reducing the aqueous uranium concentration to $<0.05 \mu \mathrm{M}$ under the $\mathrm{pH}$ range of 6.3 to 6.9 in the presence of carbonate. Results suggested the binding of uranium, irrespective of dissolved carbonate concentration or aqueous uranium concentration, occurred via surface complexation; long-term retention occurs through the transformation of sorbed apatite to chernikovite. Similar evidence for the long-term retention of uranium via initial sorption and subsequent transformation to uranium mineral phases of low solubility has been observed down gradient of the uranium ore deposit at Koongarra, Australia (Murakami et al. 1996).

\subsubsection{Selection of the Treatability Test Site}

Well 399-1-23 was selected as the candidate well for performing the treatability test (Figures 1.2 and 1.3). This well is located at the southern end of a liquid waste disposal trench that is a known source for uranium. The well is sufficiently far inland from the river such that infiltration of river water during normal high discharge conditions does not reach the well, which if that occurred, would complicate interpretation of test results. This well was also selected because of its contaminant profile, i.e., it has a moderately thick ( $\sim 6.1 \mathrm{~m}[20 \mathrm{ft}])$ interval of contaminated permeable Hanford gravel below the water table which is less significantly impacted by river level fluctuations than locations closer to the river. Depth-discrete uranium concentrations in groundwater samples collected during drilling in this well ranged up to $202 \mu \mathrm{g} / \mathrm{L}$ in the uppermost portion of the aquifer and drop off to below detection deep in the aquifer below the Hanford/Ringold contact (Figure 1.6). The highest concentration observed in the profile is located just below the Hanford/Ringold contact, indicating that vertical gradients generated during liquid waste disposal activities at the 316-5 process trenches likely drove contamination into the uppermost portion of the Ringold Formation. Although the relatively low permeability of the Ringold Formation and cessation of liquid discharge to the trenches results in limited potential for additional transport of uranium within the Ringold Formation, these contaminated sediments will continue to act as a deep uranium source at this location.

This conceptual model is supported by hydraulic conductivity values that varied greatly above and below the contact as defined by depth discrete slug tests conducted as the borehole was advanced. Values of hydraulic conductivity in the saturated Hanford formation from previous aquifer tests in the 300 Area are greater that $1,000 \mathrm{~m}(3,280 \mathrm{ft})$ per day and values in the Ringold are in the range of tens of meters per day and less. These data suggest that most of the dissolved uranium moves through the permeable interval above the Hanford/Ringold contact. Hydrogeologic interpretations of the continuous sediment core reinforce this interpretation. 


\subsection{Purpose and Scope}

Uranium stabilization through polyphosphate injection was selected as a promising technology for evaluation of its ability to meet the cleanup goals for uranium in the 300-Area aquifer. This treatability test plan outlines the approach adopted to evaluate the polyphosphate technology at field scale and to collect data for the design of a full-scale implementation. The overall objectives of the treatability test include the following:

1. Conduct a polyphosphate injection to evaluate reduction of aqueous uranium concentrations and to determine the longevity of the treatment zone.

2. Demonstrate field scale application of polyphosphate injections to identify implementation challenges and evaluate whether a full-scale deployment is feasible.

3. Determine the number of wells, reagent concentrations, volumes, injection rates, operational strategy, and longevity for polyphosphate injections for remediating uranium such that costs for larger-scale application can be effectively estimated.

Key design parameters associated with these objectives include the radius of influence of the polyphosphate amendment injections, injection concentrations, types and amount of phosphate minerals formed, reduction of aqueous uranium concentrations, and long-term treatment capacity of the amended zone. It is also recognized that site-specific hydrogeological characteristics influence the design parameters and need to be determined to conduct the treatability test and for use in determining how the process will be designed for full-scale application.

This test plan provides background information and a brief description of the polyphosphate technology in Section 1 and describes the bench-scale studies that were conducted to support development of the field-scale injection design in Section 2. Section 3 describes the treatability test performance and data quality objectives with applicable or relevant and appropriate requirements (ARARs) described in Section 4. The conceptual design for the treatability test is described in Section 5. Section 6 contains a description of the field site along with the site setup and results of site characterization activities. The sampling and analyses requirements for the treatability test are detailed in Section 7, data management is described in Section 8, and data analysis and interpretation methods discussed in Section 9. Additional sections contain health and safety planning, quality assurance, waste management, reporting, and the project schedule. 


\subsection{Bench-Scale Studies and Treatment Technology Description}

\subsection{Polyphosphate Remediation Technology}

Numerous proposals have been made to sequester uranium, in situ, with solid phase hydroxyapatite (Arey et al. 1999; Conca 1996; Gauglitz and Holterdorf 1992; Moore et al. 2001; Seaman et al. 2001; Wright et al. 1995), and watersoluble phosphate compounds, such as tribasic sodium phosphate $\left[\mathrm{Na}_{3}\left(\mathrm{PO}_{4}\right) \cdot \mathrm{nH}_{2} \mathrm{O}\right]$ (Lee et al. (1995) or phytic acid (Jensen et al. 1996; Nash et al. 1998a; Nash et al. 1998b; Nash et al. 1999). These compounds can be injected into contaminant plumes from strategically placed wells, as a chemical stabilizer for uranium and other radionuclides and heavy metals. The advantages of soluble amendments is that they allow for treatment of plumes situated deep within the subsurface and act to sequester uranium by precipitating insoluble uranium minerals rather than by reversible sorption mechanisms.

However, Wellman et al. (2005) demonstrated that compounds including tribasic sodium phosphate and phytic acid result in the rapid formation of phosphate phases. Formation of these phases occludes $\sim 30 \%$ of the fluid-filled pore space within the sedimentary formation. Rapid reduction in the hydraulic conductivity will have a significant effect on subsequently injected amendment solutions, the targeted groundwater plume, or both, by deflecting flow from the

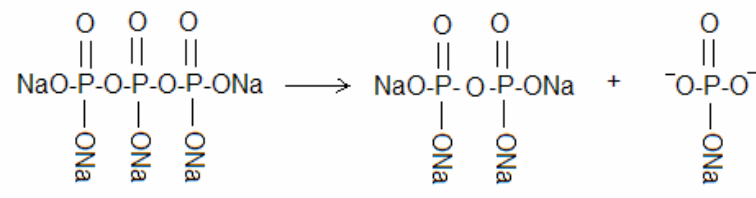

2.1. Schematic Depicting the Step-Wise Hydrolysis of Sodium Tripolyphosphate

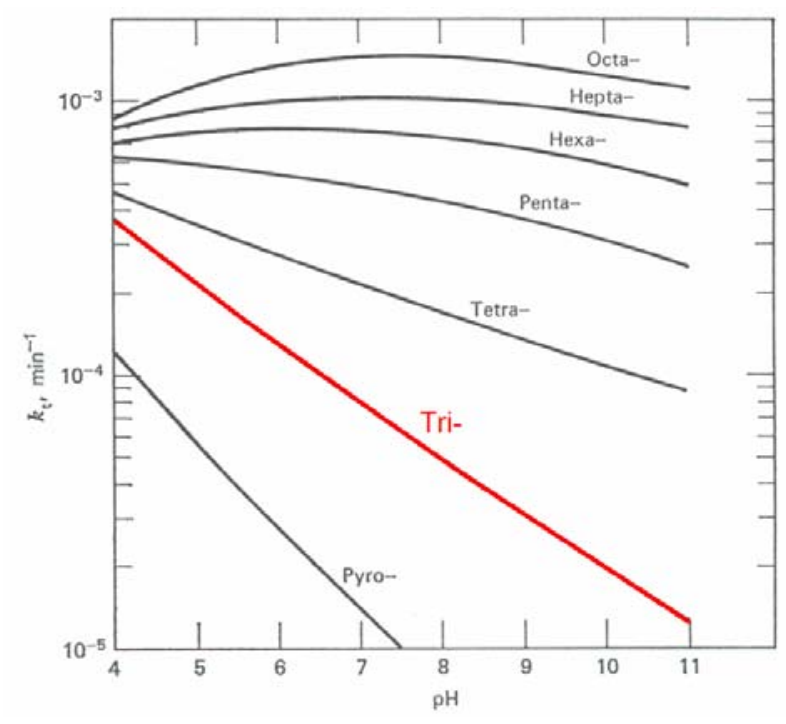

Figure 2.2. Hydrolysis Rate of Polyphosphate Molecules as a Function of $\mathrm{pH}$ (Shen and Morgan 1973) natural path.

Conversely, the use of soluble long-chain polyphosphate materials have been demonstrated to delay the precipitation of phosphate phases (Wellman et al. 2005) (Figure 2.1). Precipitation of phosphate minerals occurs when phosphate compounds degrade in water, due to hydrolysis, to yield orthophosphate molecules $\left(\mathrm{PO}_{4}{ }^{3-}\right)$. The longer the polyphosphate chain, the slower the hydrolysis reaction, which leads to orthophosphate production (Figure 2.2). Accordingly, use of a long-chain polyphosphate compound does not result in a drastic change in hydraulic conductivity of the target aquifer. 
Previous laboratory tests has demonstrated that when a soluble form of polyphosphate is injected into uranium-bearing saturated porous media, immobilization of uranium occurs due to formation of an insoluble uranyl phosphate, autunite $\left[\mathrm{Ca}\left(\mathrm{UO}_{2}\right)_{2}\left(\mathrm{PO}_{4}\right)_{2} \cdot \mathrm{nH}_{2} \mathrm{O}\right]$. These tests were conducted at conditions expected for the aquifer and used Hanford soils and groundwater containing very low concentrations of uranium $\left(10^{-6} \mathrm{M}\right)$. Because autunite sequesters uranium in the oxidized form, U(VI) rather than forcing reduction to $\mathrm{U}(\mathrm{IV})$, the possibility of re-oxidation and subsequent re-mobilization is negated. Extensive testing demonstrated the very low solubility and slow dissolution kinetics of autunite. In addition to autunite, excess phosphorous may result in apatite mineral formation, which provides a long-term source of treatment capacity. Uranium transport studies in columns packed with contaminated sediment from the Hanford 300 Area indicated that a polyphosphate solution reduces the concentration of uranium in groundwater to approximately $7 \mathrm{ppb}$, which is less than the drinking water standard (30 ppb).

Extensive laboratory tests were conducted to evaluate the following technical issues:

- Formation rate of autunite/apatite for various polyphosphate formulations.

- Polyphosphate treatment efficiency - amount of polyphosphate required to treat a pore volume of uranium contaminated groundwater.

- Polyphosphate treatment emplacement efficiency - evaluate mixing problem (i.e., effective contact or tendency for the reagent to push contaminated groundwater ahead of the treatment volume).

All experiments were conducted with sediments from the 300 Area to ensure testing conditions were representative of the remediation area.

\subsection{Autunite and Apatite Formation}

In homogeneous systems the precipitating phase first forms stable nuclei and then grows via crystallization to a macroscopic size. The nucleation rate can be expressed as:

$$
B=\beta \exp \left(\frac{-A}{\ln ^{2} s}\right)
$$

where $B=$ the rate

$\beta=$ the frequency factor

$A=$ a parameter that depends on interfacial energy

$s=$ the degree of supersaturation of the solution.

However, heterogeneous nucleation on foreign or heterogeneous surfaces lowers the interfacial energy, $A$. Equation (2.2) can be used to understand the increase in precipitation rates due to heterogeneous nucleation (Avrami 1939, 1940). The rate of heterogeneous nucleation can be expressed as:

$$
B(t)=k N(t)=k N \text { exp }(-k t)
$$

in which the nucleation rate as a function of time, $B(t)$, is equivalent to the product of a constant times the nucleation density as a function of time, $k N(t)$, and is equal to the product of a constant, $k$, the number of heterogeneous germ nuclei, $N_{o}$, and exponentially to the negative product of the constant, $k$, and time, $t$. Note the degree of supersaturation of the solution is still important, and is accounted for in the 
parameter $k$. The nucleation rate is directly proportional to the number of nucleation sites available, a number that should be large for a solution percolating through porous media. This equation also suggests that nucleation rates should be fastest at early times and will diminish exponentially.

These equations are relevant to the understanding of surface-mediated catalysis of autunite and apatite precipitation kinetics. Rapid initial rates are critical for the successful deployment of a soluble polyphosphate amendment. The above equations imply that catalysis of polyphosphate hydrolysis and solid phase precipitation should be immediate after orthophosphate contacts porous media. Furthermore, it highlights the importance of quantifying kinetic precipitation data for systems in more realistic column experiments containing actual 300 Area sediments coupled with knowledge regarding the degradation of proposed polyphosphates.

Preliminary field tracer investigations indicated a field flow rate of $\sim 15.2 \mathrm{~m}(50 \mathrm{ft}$ ) per day (see Section 6), suggesting rapid formation of autunite and apatite is required within the 300 Area subsurface for remediation. Therefore, nine potential phosphate compounds were selected for investigation as possible components to the polyphosphate amendment formulation (Table 2.1). Selection of the amendment sources was based on the solubility, hydrolysis rate, and amount of phosphorus and/or calcium provided by the respective compounds. Prior to conducting column tests, heterogeneous batch experiments were conducted in the presence of 300 Area sediment over a range of polyphosphate sources and concentrations to identify optimum source of phosphorus and calcium in order to obtain maximum precipitation of autunite and/or apatite. Batch experiments evaluated the potential composition of the polyphosphate amendment based on the extreme (i.e., 10 to 1,000 ppb) uranium concentration range measured within the 300 Area aquifer. The use of multi-length polyphosphate chain amendments was evaluated to afford rapid precipitation of autunite and/or apatite. All experiments were conducted in Hanford groundwater and in the presence of 300 Area sediments for one week at room temperature. Aqueous concentrations were monitored via inductively couple plasma-mass spectrometry (ICP-MS) and inductively couple plasma-optical emission spectrometry (ICP-OES). The exact details constituting the multiple nucleation and growth process, which may occur during the formation of calcium phosphate or the assignment of absolute limits of mineralization potential for any given set of reaction conditions, was beyond the scope of this investigation. Rather, the intent was to identify the optimum sources of calcium and phosphorous to precipitate autunite and apatite within a saturated sedimentary matrix through static batch tests.

Table 2.1. Possible Sources and Associated Solubility for Polyphosphate Amendment

\begin{tabular}{|c|c|}
\hline Amendment Source & Formula \\
\hline Sodium Orthophosphate & $\mathrm{Na}_{3} \mathrm{PO}_{4} \cdot 12 \mathrm{H}_{2} \mathrm{O}$ \\
\hline Sodium Pyrophosphate & $\mathrm{Na}_{4} \mathrm{P}_{2} \mathrm{O}_{7} \cdot 10 \mathrm{H}_{2} \mathrm{O}$ \\
\hline Sodium Tripolyphosphate & $\mathrm{Na}_{5} \mathrm{P}_{3} \mathrm{O}_{10}$ \\
\hline Sodium Trimetaphosphate & $\left(\mathrm{NaPO}_{3}\right)_{3} \cdot 6 \mathrm{H}_{2} \mathrm{O}$ \\
\hline Sodium Hexametaphosphate & $\left(\mathrm{NaPO}_{3}\right)_{6} \cdot n \mathrm{H}_{2} \mathrm{O}$ \\
\hline Calcium Dihydrogen Phosphate & $\mathrm{Ca}\left(\mathrm{H}_{2} \mathrm{PO}_{4}\right)_{2} \cdot \mathrm{H}_{2} \mathrm{O}$ \\
\hline Calcium Hydrogen Phosphate & $\mathrm{CaHPO}_{4} \cdot 2 \mathrm{H}_{2} \mathrm{O}$ \\
\hline Calcium Pyrophosphate & $\mathrm{Ca}_{2} \mathrm{P}_{2} \mathrm{O}_{7} \cdot 5 \mathrm{H}_{2} \mathrm{O}$ \\
\hline Calcium Hypophosphite & $\mathrm{Ca}\left(\mathrm{H}_{2} \mathrm{PO}_{2}\right)_{2}$ \\
\hline Calcium Chloride & $\mathrm{CaCl}_{2}$ \\
\hline
\end{tabular}


Initial batch tests were conducted based on the minimum amendment concentration as defined by previously conducted preliminary column tests, which indicated a 1,000 ppm sodium tripolyphosphate solution would reduce the aqueous concentration of uranium to near the maximum contaminant level (MCL) in $\sim 12$ pore volumes. The initial upper limit for the concentration of phosphorus was set to $1,000 \mathrm{ppm}$. Additionally, lower concentrations of 100, 250, and $500 \mathrm{ppm}$ were investigated in an effort to ensure the amendment did not contain excessive phosphorus, which may not be utilized in remediation efforts. Results further indicated the availability of calcium from 300 Area Hanford sediments and groundwater was insufficient to precipitate calcium-phosphate solid phases, since the use of a sodium phosphate compounds as the source of phosphorus requires the addition of a calcium source. The initial matrix of batch tests is given in Table 2.2.

Table 2.2. Experimental Batch Conditions for Polyphosphate Amendment Optimization

\begin{tabular}{|c|c|c|c|c|c|}
\hline & $\begin{array}{l}\text { Phosphorus } \\
\text { Conc. (ppm) }\end{array}$ & Calcium Source & $\begin{array}{l}\text { Calcium Conc. } \\
\text { (ppm) }\end{array}$ & Uraniul & c. $(\mu \mathrm{g} / \mathrm{L})$ \\
\hline \multirow{2}{*}{ Sodium Orthophosphate } & \multirow[t]{2}{*}{$1,1,000$} & & & 10 & 1,000 \\
\hline & & & & \multicolumn{2}{|c|}{0.00} \\
\hline \multirow[t]{2}{*}{ Sodium Pyrophosphate } & \multirow[t]{2}{*}{1,000} & & & 10 & 1,000 \\
\hline & & & & \multicolumn{2}{|c|}{0.00} \\
\hline \multirow[t]{2}{*}{ Sodium Tripolyphosphate } & \multirow[t]{2}{*}{1,000} & & & 10 & 1,000 \\
\hline & & & & \multicolumn{2}{|c|}{0.00} \\
\hline \multirow[t]{2}{*}{ Sodium Orthophosphate } & \multirow[t]{2}{*}{500} & & & 10 & 1,000 \\
\hline & & & & \multicolumn{2}{|c|}{0.00} \\
\hline \multirow[t]{2}{*}{ Sodium Pyrophosphate } & \multirow[t]{2}{*}{500} & & & 10 & 1,000 \\
\hline & & & & \multicolumn{2}{|c|}{0.00} \\
\hline \multirow[t]{2}{*}{ Sodium Tripolyphosphate } & \multirow[t]{2}{*}{500} & & & 10 & 1,000 \\
\hline & & & & \multicolumn{2}{|c|}{0.00} \\
\hline \multirow[t]{2}{*}{ Sodium Trimetaphosphate } & \multirow[t]{2}{*}{1,000} & & & 10 & 1,000 \\
\hline & & & & \multicolumn{2}{|c|}{0.00} \\
\hline \multirow[t]{2}{*}{ Sodium Trimetaphosphate } & \multirow[t]{2}{*}{500} & & & 10 & 1,000 \\
\hline & & & & \multicolumn{2}{|c|}{$\frac{1}{0.00}$} \\
\hline \multirow[t]{2}{*}{ Sodium Hexametaphosphate } & \multirow[t]{2}{*}{1,000} & & & 10 & 1,000 \\
\hline & & & & \multicolumn{2}{|c|}{0.00} \\
\hline \multirow[t]{2}{*}{ Sodium Hexametaphosphate } & 500 & & & 10 & 1,000 \\
\hline & & & & & \\
\hline Calcium Hypophosphite & 1,000 & & & 10 & 1,000 \\
\hline & & & & & \\
\hline Calcium Hypophosphite & 500 & & & 10 & 1,000 \\
\hline & & & & & \\
\hline Calcium Hypophosphite & 250 & & & 10 & 1,000 \\
\hline & & & & & \\
\hline Sodium Orthophosphate & 1,000 & Calcium Chloride & 500 & 10 & 1,000 \\
\hline & & & & & \\
\hline Sodium Orthophosphate & 500 & Calcium Chloride & 500 & 10 & 1,000 \\
\hline & & & & & \\
\hline Sodium Pyrophosphate & 1,000 & Calcium Chloride & 500 & 10 & 1,000 \\
\hline & & & & & \\
\hline Sodium Pyrophosphate & 500 & Calcium Chloride & 500 & 10 & 1,000 \\
\hline & & & & & \\
\hline Sodium Tripolyphosphate & 1,000 & Calcium Chloride & 500 & 10 & 1,000 \\
\hline & & & & & \\
\hline
\end{tabular}


Table 2.2. (contd)

\begin{tabular}{|c|c|c|c|c|c|}
\hline & $\begin{array}{l}\text { Phosphorus } \\
\text { Conc. (ppm) }\end{array}$ & Calcium Source & $\begin{array}{c}\text { Calcium Conc. } \\
\text { (ppm) }\end{array}$ & Uraniu & c. $(\mu \mathrm{g} / \mathrm{L})$ \\
\hline \multirow[t]{2}{*}{ "Sodium Tripolyphosphate } & \multirow[t]{2}{*}{ ב500 } & \multirow[t]{2}{*}{ "Calcium Chloride } & \multirow[t]{2}{*}{500} & 10 & 1,000 \\
\hline & & & & \multicolumn{2}{|c|}{0.00} \\
\hline \multirow[t]{2}{*}{ Sodium Trimetaphosphate } & \multirow[t]{2}{*}{1,000} & \multirow{2}{*}{$\begin{array}{c}\text { Calcium } \\
\text { Hypophosphite }\end{array}$} & \multirow[t]{2}{*}{500} & 10 & 1,000 \\
\hline & & & & \multicolumn{2}{|c|}{0.00} \\
\hline \multirow[t]{2}{*}{ Sodium Trimetaphosphate } & \multirow[t]{2}{*}{1,000} & \multirow[t]{2}{*}{ Calcium Chloride } & \multirow[t]{2}{*}{500} & 10 & 1,000 \\
\hline & & & & \multicolumn{2}{|c|}{0.00} \\
\hline \multirow[t]{2}{*}{ Sodium Trimetaphosphate } & \multirow[t]{2}{*}{500} & \multirow[t]{2}{*}{ Calcium Chloride } & \multirow[t]{2}{*}{500} & 10 & 1,000 \\
\hline & & & & \multicolumn{2}{|c|}{0.00} \\
\hline \multirow[t]{2}{*}{ Sodium Hexametaphosphate } & \multirow[t]{2}{*}{1,000} & \multirow{2}{*}{$\begin{array}{c}\text { Calcium } \\
\text { Hypophosphite }\end{array}$} & \multirow[t]{2}{*}{500} & 10 & 1,000 \\
\hline & & & & \multicolumn{2}{|c|}{0.00} \\
\hline \multirow[t]{2}{*}{ Sodium Hexametaphosphate } & \multirow[t]{2}{*}{1,000} & \multirow[t]{2}{*}{ Calcium Chloride } & \multirow[t]{2}{*}{500} & 10 & 1,000 \\
\hline & & & & \multicolumn{2}{|c|}{0.00} \\
\hline \multirow[t]{2}{*}{ Sodium Hexametaphosphate } & \multirow[t]{2}{*}{500} & \multirow[t]{2}{*}{ Calcium Chloride } & 500 & 10 & 1,000 \\
\hline & & & & & \\
\hline Calcium Hypophosphite & 1,000 & Calcium Chloride & 1,000 & 10 & 1,000 \\
\hline & & & & & \\
\hline Calcium Hypophosphite & 1,000 & Calcium Chloride & 500 & 10 & 1,000 \\
\hline & & & & & \\
\hline Calcium Hypophosphite & 500 & Calcium Chloride & 1,000 & 10 & 1,000 \\
\hline & & & & & \\
\hline Calcium Hypophosphite & 500 & Calcium Chloride & 500 & 10 & 1,000 \\
\hline & & & & & \\
\hline Calcium Hypophosphite & 250 & Calcium Chloride & 1,000 & 10 & 1,000 \\
\hline & & & & & \\
\hline Calcium Hypophosphite & 250 & Calcium Chloride & 500 & 10 & 1,000 \\
\hline & & & & & \\
\hline
\end{tabular}

All potential calcium phosphate sources were eliminated from further consideration during the initial round of batch testing. Results indicated the solubility limits of calcium dihydrogen phosphate, calcium hydrogen phosphate, and calcium pyrophosphate did not provide a sufficient source of phosphate or calcium to be included in the amendment formulation. Although calcium hypophosphite provides a sufficient source of calcium and phosphorus, rather than forming discrete precipitates this amendment formulation produces fine floccules. The formation of fine floccules as a result of phytic acid remediation has been previously shown to provide sorption sites for uranium (Nash 2000; Nash et al. 1997, 1998a, 1998b,1999). However, fine floccules may be highly mobile in the 300 Area subsurface under high flow conditions. Alternatively, it has also been previously shown that rapid flocculation due to heterogeneous nucleation in regions of moderate to low hydraulic conductivity may occlude pore space (Wellman et al. 2006). Either of these results is potentially detrimental and serves to eliminate calcium hypophosphite from further consideration as a component of the amendment formulation.

A second set of batch tests were conducted to further develop the amendment formulation using the remaining sodium phosphate compounds under consideration and calcium chloride as the soluble source for calcium (Table 2.3). As discussed above, results from initial batch tests established that phosphorus solutions $>1,000 \mathrm{ppm}$ were required to achieve $>50 \%$ removal of aqueous uranium. Results from the second set of batch tests indicated that concentrations greater than $1,000 \mathrm{ppm}$ of sodium trimetaphosphate 
Table 2.3. Down-Selected Experimental Batch Conditions for Polyphosphate Amendment Optimization

\begin{tabular}{|c|c|c|c|c|c|}
\hline Phosphate Source & $\begin{array}{l}\text { Phosphorus Conc. } \\
\text { (ppm) }\end{array}$ & Calcium Source & $\begin{array}{l}\text { Calcium Conc. } \\
\text { (ppm) }\end{array}$ & \multicolumn{2}{|c|}{$\begin{array}{c}\text { Uranium Conc., } \\
(\mu \mathrm{g} / \mathrm{L})\end{array}$} \\
\hline \multirow[t]{2}{*}{ "Sodium Orthophosphate } & \multirow[t]{2}{*}{$1,1,500$} & & & 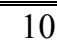 & $\begin{array}{ll}1,000 \\
\end{array}$ \\
\hline & & & & \multicolumn{2}{|c|}{0.00} \\
\hline \multirow[t]{2}{*}{ Sodium Orthophosphate } & \multirow[t]{2}{*}{2,000} & & & 10 & 1,000 \\
\hline & & & & \multicolumn{2}{|c|}{0.00} \\
\hline \multirow[t]{2}{*}{ Sodium Orthophosphate } & \multirow[t]{2}{*}{2,500} & & & 10 & 1,000 \\
\hline & & & & \multicolumn{2}{|c|}{0.00} \\
\hline \multirow[t]{2}{*}{ Sodium Pyrophosphate } & \multirow[t]{2}{*}{1,500} & & & 10 & 1,000 \\
\hline & & & & \multicolumn{2}{|c|}{0.00} \\
\hline \multirow[t]{2}{*}{ Sodium Pyrophosphate } & \multirow[t]{2}{*}{2,000} & & & 10 & 1,000 \\
\hline & & & & \multicolumn{2}{|c|}{0.00} \\
\hline \multirow[t]{2}{*}{ Sodium Pyrophosphate } & \multirow[t]{2}{*}{2,500} & & & 10 & 1,000 \\
\hline & & & & \multicolumn{2}{|c|}{0.00} \\
\hline \multirow[t]{2}{*}{ Sodium Tripolyphosphate } & \multirow[t]{2}{*}{1,500} & & & 10 & 1,000 \\
\hline & & & & & \\
\hline Sodium Tripolyphosphate & 2,000 & & & 10 & 1,000 \\
\hline & & & & & \\
\hline Sodium Tripolyphosphate & 2,500 & & & 10 & 1,000 \\
\hline & & & & & \\
\hline Sodium & 1,500 & & & 10 & 1,000 \\
\hline Trimetaphosphate & & & & & \\
\hline Sodium & 2,000 & & & 10 & 1,000 \\
\hline Trimetaphosphate & & & & & \\
\hline Sodium & 2,500 & & & 10 & 1,000 \\
\hline Trimetaphosphate & & & & & \\
\hline Sodium & 1,500 & & & 10 & 1,000 \\
\hline Hexametaphosphate & & & & & \\
\hline Sodium & 2,000 & & & 10 & 1,000 \\
\hline Hexametaphosphate & & & & & \\
\hline Sodium & 2,500 & & & 10 & 1,000 \\
\hline Hexametaphosphate & & & & & \\
\hline Sodium Orthophosphate & 1,500 & Calcium Chloride & 1,000 & 10 & 1,000 \\
\hline & & & & & \\
\hline Sodium Orthophosphate & 1,500 & Calcium Chloride & 1,500 & 10 & 1,000 \\
\hline Sodium Orthophosphate & 2,000 & Calcium Chloride & 1,000 & 10 & 1,000 \\
\hline & & & & & \\
\hline Sodium Orthophosphate & 2,000 & Calcium Chloride & 1,500 & 10 & 1,000 \\
\hline & & & & & \\
\hline Sodium Orthophosphate & 2,500 & Calcium Chloride & 1,000 & 10 & 1,000 \\
\hline & & & & & \\
\hline Sodium Orthophosphate & 2,500 & Calcium Chloride & 1,500 & 10 & 1,000 \\
\hline & & & & & \\
\hline Sodium Pyrophosphate & 1,500 & Calcium Chloride & 1,000 & 10 & 1,000 \\
\hline & & & & & \\
\hline Sodium Pyrophosphate & 1,500 & Calcium Chloride & 1,500 & 10 & 1,000 \\
\hline & & & & & \\
\hline Sodium Pyrophosphate & 2,000 & Calcium Chloride & 1,000 & 10 & 1,000 \\
\hline & & & & & \\
\hline Sodium Pyrophosphate & 2,000 & Calcium Chloride & 1,500 & 10 & 1,000 \\
\hline & & & & & \\
\hline
\end{tabular}


Table 2.3. (contd)

\begin{tabular}{|c|c|c|c|c|c|}
\hline Phosphate Source & $\begin{array}{c}\text { Phosphorus Conc. } \\
(\mathrm{ppm})\end{array}$ & Calcium Source & $\begin{array}{c}\text { Calcium Conc. } \\
(\mathrm{ppm})\end{array}$ & \multicolumn{2}{|c|}{$\begin{array}{c}\text { Uranium Conc., } \\
(\mu \mathrm{g} / \mathrm{L})\end{array}$} \\
\hline \multirow[t]{2}{*}{ Sodium Pyrophosphate } & \multirow[t]{2}{*}{2,500} & \multirow[t]{2}{*}{ Calcium Chloride } & \multirow[t]{2}{*}{1,000} & 10 & 1,000 \\
\hline & & & & \multicolumn{2}{|c|}{0.00} \\
\hline Sodium Pyrophosphate & 2,500 & Calcium Chloride & 1,500 & 10 & 1,000 \\
\hline \multirow[t]{2}{*}{ Sodium Tripolyphosphate } & \multirow[t]{2}{*}{1,500} & \multirow[t]{2}{*}{ Calcium Chloride } & \multirow[t]{2}{*}{1,000} & 10 & 1,000 \\
\hline & & & & \multicolumn{2}{|c|}{0.00} \\
\hline \multirow[t]{2}{*}{ Sodium Tripolyphosphate } & \multirow[t]{2}{*}{1,500} & \multirow[t]{2}{*}{ Calcium Chloride } & \multirow[t]{2}{*}{1,500} & 10 & 1,000 \\
\hline & & & & \multicolumn{2}{|c|}{0.00} \\
\hline \multirow[t]{2}{*}{ Sodium Tripolyphosphate } & \multirow[t]{2}{*}{2,000} & \multirow[t]{2}{*}{ Calcium Chloride } & \multirow[t]{2}{*}{1,000} & 10 & 1,000 \\
\hline & & & & \multicolumn{2}{|c|}{0.00} \\
\hline \multirow[t]{2}{*}{ Sodium Tripolyphosphate } & \multirow[t]{2}{*}{2,000} & Calcium Chloride & 1,500 & 10 & 1,000 \\
\hline & & & & & 00 \\
\hline Sodium Tripolyphosphate & 2,500 & Calcium Chloride & 1,000 & 10 & 1,000 \\
\hline & & & & & 00 \\
\hline Sodium Tripolyphosphate & 2,500 & Calcium Chloride & 1,500 & 10 & 1,000 \\
\hline Sodium & 1,500 & Calcium Chloride & 1,000 & 10 & 1,000 \\
\hline Trimetaphosphate & & & & & 00 \\
\hline Sodium & 1,500 & Calcium Chloride & 1,500 & 10 & 1,000 \\
\hline Trimetaphosphate & & & & & 00 \\
\hline Sodium & 2,000 & Calcium Chloride & 1,000 & 10 & 1,000 \\
\hline Trimetaphosphate & & & & & 00 \\
\hline Sodium & 2,000 & Calcium Chloride & 1,500 & 10 & 1,000 \\
\hline Trimetaphosphate & & & & & 00 \\
\hline Sodium & 2,500 & Calcium Chloride & 1,000 & 10 & 1,000 \\
\hline Trimetaphosphate & & & & & 00 \\
\hline Sodium & 2,500 & Calcium Chloride & 1,500 & 10 & 1,000 \\
\hline Trimetaphosphate & & & & & \\
\hline Sodium Hexametaphosphate & 1,500 & Calcium Chloride & 1,000 & 10 & 1,000 \\
\hline & & & & & 00 \\
\hline Sodium Hexametaphosphate & 1,500 & Calcium Chloride & 1,500 & 10 & 1,000 \\
\hline & & & & & 00 \\
\hline Sodium Hexametaphosphate & 2,000 & Calcium Chloride & 1,000 & 10 & 1,000 \\
\hline & & & & & 00 \\
\hline Sodium Hexametaphosphate & 2,000 & Calcium Chloride & 1,500 & 10 & 1,000 \\
\hline & & & & & 00 \\
\hline Sodium Hexametaphosphate & 2,500 & Calcium Chloride & 1,000 & 10 & 1,000 \\
\hline & & & & & 00 \\
\hline Sodium Hexametaphosphate & 2,500 & Calcium Chloride & 1,500 & 10 & 1,000 \\
\hline & & & & & 00 \\
\hline
\end{tabular}

produced fine floccules, which eliminated it from further consideration for reasons previously noted. Although sodium hexametaphosphate produced discrete precipitates, the extent of precipitation was significantly less than for sodium ortho-, pyro-, or tripolyphosphate under equivalent conditions (Figure 2.3). Additionally, sodium hexametaphosphate reduced the $\mathrm{pH}$ of the groundwater by one to two $\mathrm{pH}$ units. Therefore, sodium hexametaphosphate was eliminated from further consideration for the amendment formulation. 
Figure 2.3 displays the percent of calcium and phosphorus removed from solution as a function of the calcium to phosphorus ratio in the presence of 10 and 1,000 ppb uranium. The objective of these tests was to identify the calcium to phosphorus ratio for maximum removal from the aqueous phase. The mechanisms of removal may include sorption and precipitation; however, no attempt was made to discern the degree of removal based on these respective mechanisms. Greater than $90 \%$ removal of calcium and phosphorus from solution was achieved in the presence of sodium orthophosphate, sodium pyrophosphate, sodium tripolyphosphate, respectively, with calcium chloride (Figure 2.3). The optimum ratio of calcium to phosphorus for sodium orthophosphate and sodium pyrophosphate is 1.5 ; whereas, the optimum calcium to phosphorus ratio for sodium tripolyphosphate is $\sim 2.4$. Moreover, the uptake of uranium was rapid ( $<2 \mathrm{~min}$ ) and complete, $\sim 100 \%$, which is discussed in detail below.

Tripolyphosphate is a primary ingredient in detergents; however, as illustrated above tripolyphosphate degrades to pyro- and orthophosphate. As such, the removal of these phosphate compounds from wastewater has been the subject of several investigations conducted for over five decades. Research beginning in the mid-60s demonstrated the efficacy of utilizing calcium and/or lime to precipitate stable calcium-phosphate solid phases, including apatite for direct removal of phosphate (Ferguson et al. 1970, 1973; Jenkins et al. 1971; Schmid and McKinney 1968).
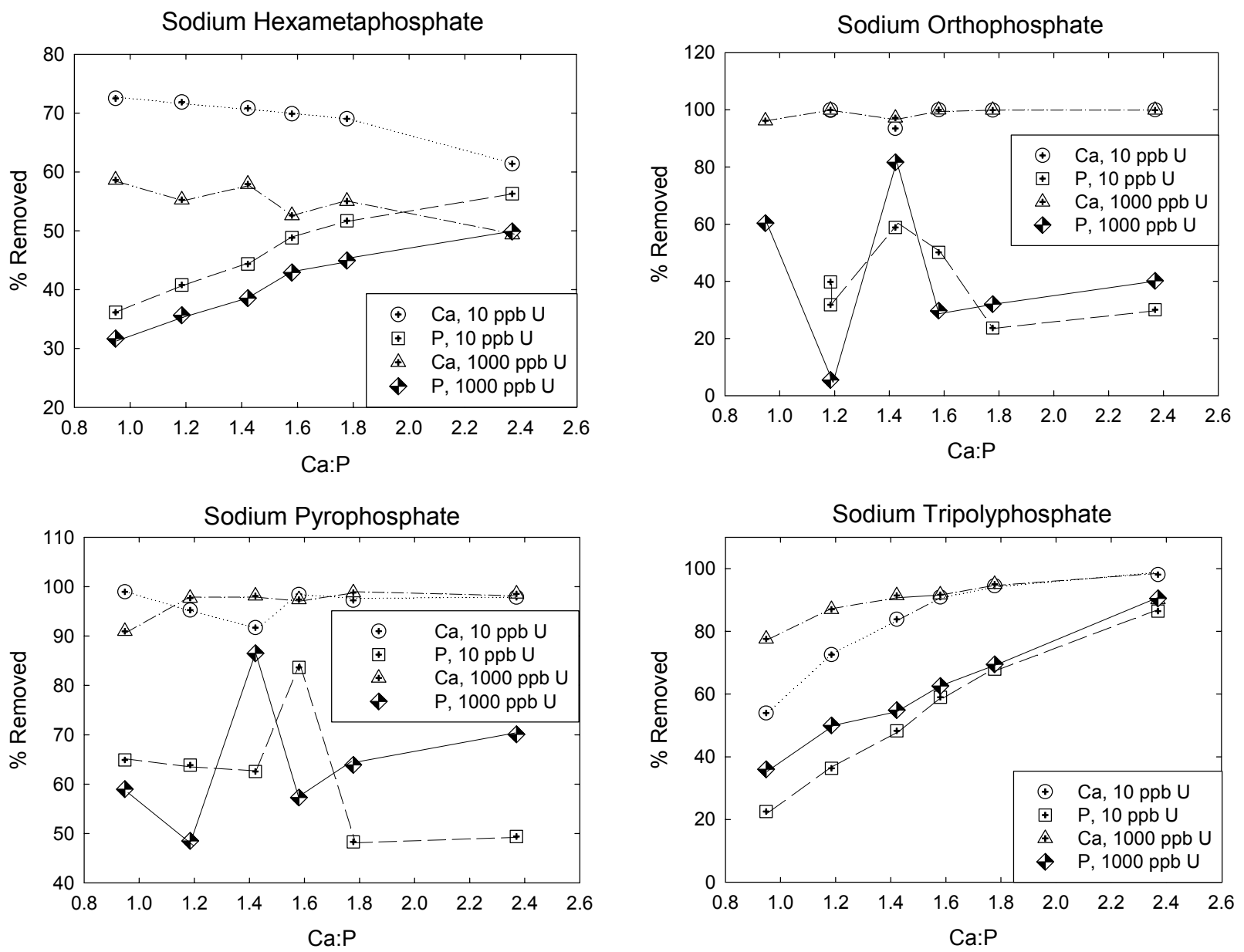

Figure 2.3. Percent Removal of Calcium and Phosphorus as a Function of Calcium to Phosphorus Ratio 
However, results of these early investigations underscore the importance of conducting site-specific tests to optimize the formation of apatite based on environmental parameters including $\mathrm{pH}$, carbonate concentration, etc.

\subsubsection{Column Experiments}

Column experiments were conducted to obtain the following information:

- Optimize amendment formulation based on results of batch tests for amendment emplacement and the formation of autunite and apatite.

- Quantify the mobility of ortho-, pyro-, and tripolyphosphate individually as well as a mixed formulation in order to evaluate the differences in retardation due to the interaction between the various phosphate compounds.

- Evaluate the mobility of calcium.

\subsubsection{Amendment Formulation, Efficacy and Emplacement}

Saturated column tests were conducted to evaluate the concentration of total phosphorus and calcium, the ratio of ortho-, pyro-, and tripolyphosphate, the ratio of calcium to phosphorus, $\mathrm{pH}$, the injection order to optimize emplacement of the amendment and the extent of treatment, reduction in aqueous uranium concentration, and the formation of autunite and apatite. Polyvinyl chloride (PVC) columns (length, $L=$ $30.48 \mathrm{~cm}$; radius, $r=2.54 \mathrm{~cm}$; and bulk volume, $V_{b}=194.04-202.20 \mathrm{~cm}^{3}$ ) were packed uniformly with sediment from 300 Area cores and were saturated with Hanford groundwater to ensure chemical equilibrium. Preliminary characterization results indicated the uranium concentration within the aqueous and solid matrix of the sediment cores is below the MCL for uranium. As such, in order to effectively evaluate polyphosphate amendments for uranium remediation, it was necessary to use a solution of Hanford groundwater spiked with aqueous uranium as the influent solution. The uranium concentration in the pore fluid was $1,000 \mathrm{ppb}$. This allowed the efficacy of the polyphosphate amendment to be evaluated under maximum uranium concentrations.

Several injection scheme variations were investigated and are discussed in further detail below; however, in general, following saturation and attainment of chemical equilibrium with uranium-spiked groundwater, the influent solution was changed to Hanford groundwater containing the polyphosphate amendment or calcium followed by the other respective solution. Aqueous concentrations were monitored via ICP-MS and ICP-OES; solid phase formation was evaluated via fluorescence spectroscopy using short wave ultraviolet (UV) radiation, $254 \mathrm{~nm}$.

Sodium orthophosphate $\left(\mathrm{Na}_{3} \mathrm{PO}_{4} \bullet 12 \mathrm{H}_{2} \mathrm{O}\right)$, sodium pyrophosphate $\left(\mathrm{Na}_{4} \mathrm{P}_{2} \mathrm{O}_{7} \bullet 10 \mathrm{H}_{2} \mathrm{O}\right)$, and sodium tripolyphosphate $\left(\mathrm{Na}_{5} \mathrm{P}_{3} \mathrm{O}_{10}\right)$ provided the source of each respective phosphate for all phosphorus amendment formulations and calcium chloride $\left(\mathrm{CaCl}_{2}\right)$ was used as the source of calcium. Calcium rapidly precipitates with orthophosphate; therefore, all injections were conducted in two phases by injecting either the calcium solution followed by the phosphorus solution or vice versa. Details regarding the amendment formulation, injection order, calcium to total phosphorus ratio, amendment $\mathrm{pH}$ and concentrations are summarized in Table 2.4. The $\mathrm{pH}$ of the amendment solutions was as mixed, unless specified $\mathrm{pH} 7$ which was attained by adjustment with nitric acid. 
Table 2.4. Experimental Parameters for Polyphosphate Amendment Optimization Column Tests

\begin{tabular}{|c|c|c|c|c|c|c|}
\hline $\begin{array}{l}\text { Column } \\
\text { No. }\end{array}$ & Amendment Source & $\begin{array}{c}\mathrm{Wt} \% \text { Phosphate } \\
\text { Source }\end{array}$ & $\begin{array}{c}\text { Injection } \\
\text { Order }\end{array}$ & $\mathrm{Ca}: \mathrm{P}_{\text {total }}$ & $\mathrm{pH}$ & Conc., $\mathrm{M}$ \\
\hline \multirow[t]{4}{*}{ 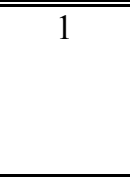 } & Ortho $[\mathrm{P}]_{\mathrm{aq}}$ & 0.25 & \multirow{3}{*}{1} & \multirow{4}{*}{2.2} & \multirow[t]{4}{*}{7} & $1.32 \times 10^{-3}$ \\
\hline & Pyro $[\mathrm{P}]_{\mathrm{aq}}$ & 0.25 & & & & $6.58 \times 10^{-4}$ \\
\hline & Tripoly $[\mathrm{P}]_{\mathrm{aq}}$ & 0.5 & & & & $8.77 \times 10^{-4}$ \\
\hline & Calcium & & 2 & & & $1.15 \times 10^{-2}$ \\
\hline \multirow[t]{4}{*}{2} & "Ortho $[\mathrm{P}]_{\mathrm{aq}}$ & 0.25 & \multirow[t]{3}{*}{$\overline{11}$} & \multirow[t]{4}{*}{2.2} & \multirow[t]{4}{*}{7} & $1.97 \times 10^{-3}$ \\
\hline & Pyro $[\mathrm{P}]_{\mathrm{aq}}$ & 0.25 & & & & $9.87 \times 10^{-4}$ \\
\hline & Tripoly $[\mathrm{P}]_{\mathrm{aq}}$ & 0.5 & & & & $1.32 \times 10^{-3}$ \\
\hline & Calcium & & 2 & & & $1.74 \times 10^{-2}$ \\
\hline \multirow[t]{4}{*}{3} & Ortho $[\mathrm{P}]_{\mathrm{aq}}$ & 0.25 & \multirow[t]{3}{*}{$\bar{~} 1$} & \multirow[t]{4}{*}{2.2} & \multirow[t]{4}{*}{ No adj. } & $1.97 \times 10^{-3}$ \\
\hline & Pyro $[\mathrm{P}]_{\mathrm{aq}}$ & 0.25 & & & & $9.87 \times 10^{-4}$ \\
\hline & Tripoly $[\mathrm{P}]_{\mathrm{aq}}$ & 0.5 & & & & $1.32 \times 10^{-3}$ \\
\hline & Calcium & & 2 & & & $1.74 \times 10^{-2}$ \\
\hline \multirow[t]{4}{*}{ 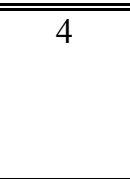 } & OFrtho $[\mathrm{P}]_{\mathrm{aq}}$ & 0.375 & \multirow[t]{3}{*}{ " 1} & \multirow[t]{4}{*}{2.2} & \multirow[t]{4}{*}{ No adj. } & $2.63 \times 10^{-3}$ \\
\hline & Pyro $[\mathrm{P}]_{\mathrm{aq}}$ & 0.25 & & & & $1.32 \times 10^{-3}$ \\
\hline & Tripoly $[\mathrm{P}]_{\mathrm{aq}}$ & 0.375 & & & & $1.75 \times 10^{-3}$ \\
\hline & Calcium & & 2 & & & $2.32 \times 10^{-2}$ \\
\hline \multirow[t]{4}{*}{$\overline{5}$} & Ortho $[\mathrm{P}]_{\mathrm{aq}}$ & 0.25 & \multirow[t]{3}{*}{$\overline{1} 1$} & \multirow[t]{4}{*}{1.67} & \multirow[t]{4}{*}{ No adj. } & $3.47 \times 10^{-3}$ \\
\hline & Pyro $[\mathrm{P}]_{\mathrm{aq}}$ & 0.25 & & & & $1.74 \times 10^{-3}$ \\
\hline & Tripoly $[\mathrm{P}]_{\mathrm{aq}}$ & 0.5 & & & & $2.32 \times 10^{-3}$ \\
\hline & Calcium & & 2 & & & $2.32 \times 10^{-2}$ \\
\hline \multirow[t]{4}{*}{ "6 } & $\begin{array}{l}\text { Ortho }[\mathrm{P}]_{\mathrm{aq}} \\
\end{array}$ & 0.25 & \multirow[t]{3}{*}{ "1 } & \multirow[t]{4}{*}{ "1.67 } & $\overline{77}$ & $3.47 \times 10^{-3}$ \\
\hline & Pyro $[\mathrm{P}]_{\mathrm{aq}}$ & 0.25 & & & & $1.74 \times 10^{-3}$ \\
\hline & Tripoly $[\mathrm{P}]_{\mathrm{aq}}$ & 0.5 & & & & $2.32 \times 10^{-3}$ \\
\hline & Calcium & & 2 & & & $2.32 \times 10^{-2}$ \\
\hline $7 / 111$ & Ortho $[\mathrm{P}]_{\mathrm{aq}}$ & 0.25 & 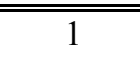 & 2.2 & "No adj./7 & $2.63 \times 10^{-3}$ \\
\hline & Pyro $[\mathrm{P}]_{\mathrm{aq}}$ & 0.25 & & & & $1.32 \times 10^{-3}$ \\
\hline & Tripoly $[\mathrm{P}]_{\mathrm{aq}}$ & 0.5 & & & & $1.75 \times 10^{-3}$ \\
\hline & Calcium & & 2 & & & $2.32 \times 10^{-2}$ \\
\hline $8 / 12$ & Ortho $[\mathrm{P}]_{\mathrm{aq}}$ & 0.25 & 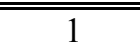 & 2.2 & "No adj./7 & $6.58 \times 10^{-3}$ \\
\hline & Pyro $[\mathrm{P}]_{\mathrm{aq}}$ & 0.25 & & & & $3.29 \times 10^{-3}$ \\
\hline & Tripoly $[\mathrm{P}]_{\mathrm{aq}}$ & 0.5 & & & & $4.39 \times 10^{-3}$ \\
\hline & Calcium & & 2 & & & $5.79 \times 10^{-2}$ \\
\hline 9/13 & Ortho $[\mathrm{P}]_{\mathrm{aq}}$ & 0.25 & 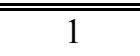 & 2.2 & No. Adj/7 & $9.21 \times 10^{-3}$ \\
\hline & Pyro $[\mathrm{P}]_{\mathrm{aq}}$ & 0.25 & & & & $4.61 \times 10^{-3}$ \\
\hline & Tripoly $[\mathrm{P}]_{\mathrm{aq}}$ & 0.5 & & & & $6.14 \times 10^{-3}$ \\
\hline & Calcium & & 2 & & & $8.10 \times 10^{-2}$ \\
\hline "10/14 & "Ortho $[\mathrm{P}]_{\mathrm{aq}}$ & 0.25 & 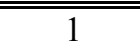 & 2.2 & "No Adj./7 & $1.32 \times 10^{-2}$ \\
\hline & Pyro $[\mathrm{P}]_{\mathrm{aq}}$ & 0.25 & & & & $6.58 \times 10^{-3}$ \\
\hline & Tripoly $[\mathrm{P}]_{\mathrm{aq}}$ & 0.5 & & & & $8.77 \times 10^{-3}$ \\
\hline & Calcium & & 2 & & & $1.16 \times 10^{-1}$ \\
\hline$\overline{15}$ & Ortho $[\mathrm{P}]_{\mathrm{aq}}$ & 0.25 & 2 & 1.9 & No Adj. & $1.32 \times 10^{-2}$ \\
\hline & Pyro $[\mathrm{P}]_{\mathrm{aq}}$ & 0.25 & & & & $6.58 \times 10^{-3}$ \\
\hline & Tripoly $[\mathrm{P}]_{\mathrm{aq}}$ & 0.5 & & & & $8.77 \times 10^{-3}$ \\
\hline & Calcium & & 1 & & & $9.98 \times 10^{-2}$ \\
\hline
\end{tabular}


Table 2.4. (contd)

\begin{tabular}{|c|c|c|c|c|c|c|}
\hline $\begin{array}{l}\text { Column } \\
\text { No. }\end{array}$ & Amendment Source & $\begin{array}{c}\mathrm{Wt} \% \text { Phosphate } \\
\text { Source }\end{array}$ & $\begin{array}{c}\text { Injection } \\
\text { Order }\end{array}$ & $\mathrm{Ca}: \mathrm{P}_{\text {total }}$ & $\mathrm{pH}$ & Conc., $\mathrm{M}$ \\
\hline \multirow[t]{4}{*}{ 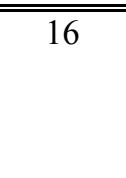 } & OOrtho $[\mathrm{P}]_{\mathrm{aq}}$ & 0.25 & \multirow[t]{3}{*}{2} & \multirow[t]{4}{*}{1.9} & \multirow[t]{4}{*}{7} & $1.32 \times 10^{-2}$ \\
\hline & Pyro $[\mathrm{P}]_{\mathrm{aq}}$ & 0.25 & & & & $6.58 \times 10^{-3}$ \\
\hline & Tripoly $[\mathrm{P}]_{\mathrm{aq}}$ & 0.5 & & & & $8.77 \times 10^{-3}$ \\
\hline & Calcium & & 1 & & & $9.98 \times 10^{-2}$ \\
\hline \multirow[t]{4}{*}{17} & Ortho $[\mathrm{P}]_{\mathrm{aq}}$ & 0.25 & \multirow[t]{3}{*}{ 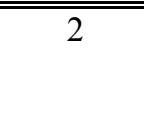 } & \multirow[t]{4}{*}{2.2} & \multirow[t]{4}{*}{ 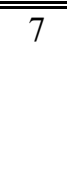 } & $9.21 \times 10^{-3}$ \\
\hline & Pyro $[\mathrm{P}]_{\mathrm{aq}}$ & 0.25 & & & & $4.61 \times 10^{-3}$ \\
\hline & Tripoly $[\mathrm{P}]_{\mathrm{aq}}$ & 0.5 & & & & $6.14 \times 10^{-3}$ \\
\hline & Calcium & & 1 & & & $8.10 \times 10^{-2}$ \\
\hline \multirow[t]{4}{*}{18} & Ortho $[\mathrm{P}]_{\mathrm{aq}}$ & 0.25 & \multirow[t]{3}{*}{ 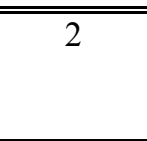 } & \multirow[t]{4}{*}{2.2} & \multirow[t]{4}{*}{$\overline{7} 7$} & $1.32 \times 10^{-2}$ \\
\hline & Pyro $[\mathrm{P}]_{\mathrm{ag}}$ & 0.25 & & & & $6.58 \times 10^{-3}$ \\
\hline & Tripoly $[\mathrm{P}]_{\mathrm{aq}}$ & 0.5 & & & & $8.77 \times 10^{-3}$ \\
\hline & Calcium & & 1 & & & $1.16 \times 10^{-1}$ \\
\hline
\end{tabular}

Visual inspection of sediment removed from columns 1-4 after application of the associated amendment formulations illustrated the formation of fluorescent green precipitates under shortwave UV radiation, $254 \mathrm{~nm}$, indicative of uranium-phosphate phases (Figure 2.4). Qualitatively, the precipitate appeared to be within or coating $\sim 50 \%$ of the sedimentary matrix. ICP-MS results from columns 1 through 4 demonstrated $\sim 50 \%$ reduction in the aqueous uranium concentration suggesting a higher concentration of phosphorus and calcium in the amendment formulation was necessary. Comparison of columns 2 and 3 suggested there was little effect of $\mathrm{pH}$ in reducing the aqueous uranium concentration; however, precipitation of calciumphosphate was more significant under $\mathrm{pH}$ conditions $\sim 7$.

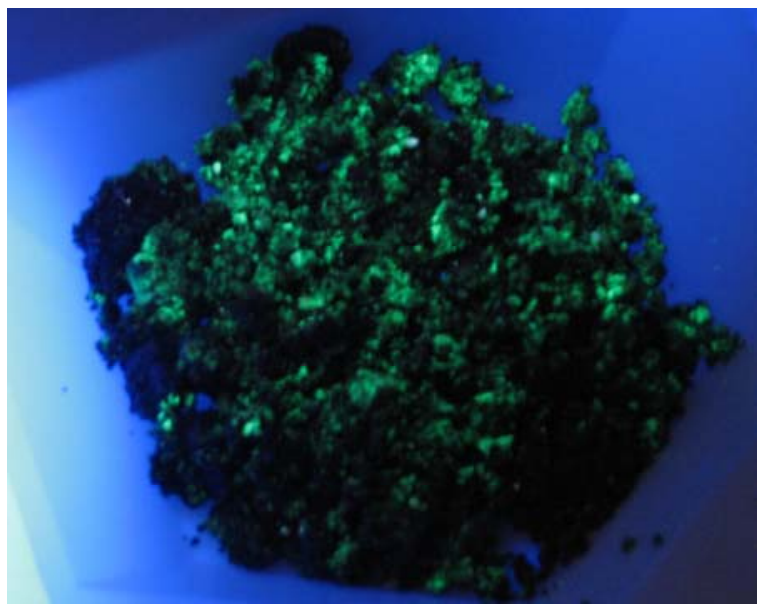

Figure 2.4. Representative Photo of Sediment Sectioned from the Effluent End of Column 1 Illustrating the Visual Identification of UraniumPhosphate Under Shortwave UV Radiation

Precipitation of apatite from homogeneous matrices has been suggested to proceed through initial precipitation of amorphous calcium phosphate, which serves as a template for the heterogeneous nucleation of octacalcium phosphate (OCP) (Feenstra and de Bruyn 1979). In turn, OCP serves as a template for epitaxial growth of hydroxyapatite (Brown et al. 1962; Eanes et al. 1965; Eanes and Meyer 1977; Eanes and Posner 1965; Feenstra and de Bruyn 1979). The conversion of amorphous to crystalline phases involving an epitaxial matching of the depositing phase onto the hydroxyapatite crystalline substrate is consistent with a hypothesized autocatalytic conversion mechanism (Boskey and Posner 1973; Boskey and Posner 1976; Eanes and Posner 1965). This explains the significance of apatite seed crystals for accelerated precipitation of hydroxyapatite from solution (Amjad et al. 1981; Boskey and Posner 1973; Brown 1980, 1981a, 1981b; Inskeep and Silvertooth 1988; Nancollas and Mohan 1970; Nancollas and Tomazic 1974). Once the reservoir of non-apatitic calcium-phosphate is depleted during the conversion process, the increase in size of apatite crystals proceeds by Ostwald ripening in which the overall number of apatite crystals in reduced by consolidation and recrystalization (Eanes and Posner 
1970). The Gibbs-Kelvin effect states the thermodynamic driving force for this mechanism is that the equilibrium solubility of small particles decreases with increasing size. Therefore, in a suspension of heterogeneous particles, the smaller particles have a higher solubility than larger particles. The smaller particles dissolve and the larger particles continue to grow (Eanes et al. 1965; Eanes and Posner 1970). However, the growth rate of apatite is controlled by surface nucleation and/or dislocation mechanisms (Eanes and Posner 1970). As such, hydroxyapatite growth is limited by a process occurring at the crystal interface (Nancollas and Mohan 1970) and therefore dependent on the surface area (Inskeep and Silvertooth 1988). (Christoffersen and Christoffersen 1982) proposed that protonation of phosphate groups at the crystal surface catalyzes the exchange of phosphate between the apatite surface and the bulk solution, thereby accelerating growth. At $\mathrm{pH} 7.4$, hydroxyapatite is the least soluble phase and most thermodynamically stable, in the absence of kinetic complications (Nancollas and Tomazic 1974). This is consistent with findings regarding the growth of fluorapatite (FAP) wherein a direct relationship exists between the growth rate of FAP and $\mathrm{pH}$ (van Cappellen and Berner 1991). For a given degree of supersaturation, the growth rate of FAP at $\mathrm{pH} 7$ was twice that when measured at $\mathrm{pH} 8$.

This underscores the complex series of elementary reactions in the precipitation of hydroxyapatite, which suggests either direct precipitation from solution on the surface of hydroxyapatite seed crystals, precipitation from surface or absorbed calcium and phosphate whose concentrations are dependent on solution of calcium and phosphate (Inskeep and Silvertooth 1988). The compactness of the heterogeneous nucleus is more conducive to formation of hydroxyapatite than the diffuse homogeneous ionic nucleus (Garten and Head 1966). However, macromolecules can influence both the initial formation of amorphous calcium phosphate and conversion to apatite (Termine et al. 1970; Termine and Posner 1970). Macromolecules contain sites within their internal or solvation-shell favoring both nucleation and growth (Termine et al. 1970; Termine and Posner 1970). Additionally, a decreased dielectric constant enhances initial mineral phase separation and amorphous-crystalline conversion. Thus, a partially non-polar region within a macromolecule, as well as more polar regions, may provide a local milieu favorable for amorphous calcium phosphate formation or crystal conversion (Termine et al. 1970). Sodium tripolyphosphate serves as a favorable nucleating surface toward initial mineral phase separation and formation of amorphous calcium-phosphate with orthophosphate. When mineralization nucleation is considered relative to initial mineral phase depositions, pyrophosphate is a strong nucleating agent (Termine and Posner 1970).

Schmid and McKinney (1968) identified key processes involved in the formation of apatite from mixtures of ortho-, pyro-, and tripolyphosphate. Results of sorption studies illustrated orthophosphate sorbs onto polyphosphate near $\mathrm{pH} \sim 7$ to 9 . Although, tripolyphosphate does not readily precipitate in the absence of orthophosphate, sorption of orthophosphate onto tripolyphosphate serves as a heterogeneous nucleating surface to promote precipitation. As orthophosphate begins to precipitate, the $\mathrm{pH}$ of the solution increases slightly, and as this occurs, the degradation of tripolyphosphate is accelerated to form ortho- and pyrophosphate. This further enhances precipitation by providing additional orthophosphate. Furthermore, pyrophosphate produces a heavy, fast settling precipitate with calcium which increases the settling rate of the finer precipitates formed from tripolyphosphate. In the absence of orthophosphate, precipitation from tripolyphosphate is only $\sim 50 \%$ of that under the same conditions in the presence of both ortho- and tripolyphosphate.

A key additional consideration regarding the use of a polyphosphate amendment in the precipitation of calcium phosphate under conditions present within the 300 Area is the effect of carbonate. Precipitation of calcium phosphate from monophosphate solutions is strongly influenced by competing 
reactions to produce calcium carbonates (Diaz et al. 1994; Lindsay and Moreno 1960). Jenkins et al. (1971) demonstrate that in Ca- $\mathrm{PO}_{4-}$ $\mathrm{CO}_{3}-\mathrm{H}^{+}-\mathrm{H}_{2} \mathrm{O}$ system precipitation of calcium carbonate competes with the precipitation of calcium phosphate under the $\mathrm{pH}$ range of 9 to 10.5 . Between $\mathrm{pH} 7.5$ to 8.5 and above $\mathrm{pH} 10.5$, calcium phosphate precipitation controls the phosphorus concentration. Increases in the bicarbonate concentration increased the initial induction period required for precipitation of calcium phosphate and also decreased the subsequent rate of removal as a function of bicarbonate concentration.

By complexing calcium and sorbing to mineral surfaces, polyphosphate compounds effectively reduce both the rate and extent of calcium carbonate precipitation, simultaneously enhancing the rate of calcium phosphate precipitation by reducing the competing reaction and essentially "directing" calcium to participate in reactions resulting in calcium phosphate precipitation (Ferguson et al. 1973).

Column 4 highlighted the significance of the complex relationship between ortho-, pyro-, and tripolyphosphate. Although the concentration of aqueous uranium was decreased $\sim 50 \%$, the formation of calcium-phosphate was restricted to a discrete region within the sediment matrix (Figure 2.5).

Columns 5 and 6, in comparison to columns 3 and 2, respectively, illustrated the significance of the calcium to phosphorus ratio. Qualitatively, the calcium to phosphorus ratio of 2.2 afforded more precipitation than a calcium to phosphorus ratio of 1.67 which gave no visual indication of calciumphosphate precipitation. Although batch testing indicated the optimal calcium to phosphorus ratio for removal of calcium and phosphorus in the presence of both ortho-, and pyrophosphate was $\sim 1.5$, columns 1 through 4 illustrate the significance of the calcium to phosphorus ratio of 2.4 indicated by tripolyphosphate batch testing. This supports batch test results, which indicated that a total calcium to phosphorus ratio of $\geq 1.9$ was optimal.

The calcium and phosphorus formulations were conducted in duplicate using columns 7 through 14 at $\mathrm{pH} 7$ and at the unadjusted $\mathrm{pH}$ of the solutions as measured, $\sim 10$ and 11. The calcium to phosphorus ratio for all columns was 2.2. The concentration of calcium varied from $2.32 \times 10^{-2} \mathrm{M}$ to $1.16 \times 10^{-1} \mathrm{M}$ and the phosphorus concentrations ranged from $1.05 \times 10^{-2} \mathrm{M}$ to $5.26 \times 10^{-2} \mathrm{M}$. Precipitation of calcium-phosphate in columns 7 through 10 was limited, eliminating consideration of non-adjusted amendment solutions. Alternatively, columns 11 through 14 demonstrated an increase in the degree of calcium-phosphate precipitation utilizing the same amendment formulation adjusted to $\mathrm{pH} \sim 7$. In columns 11 and 12 the concentration of aqueous uranium in the effluent solution increased over the first 0.5 to 1 pore volumes during remedy injection to concentrations 1.2 to 3 times the influent uranium concentration. However, increasing the concentration of phosphorus and calcium in the amendment formulation precluded this phenomena. Additionally, the concentration of aqueous uranium was reduced to below the MCL, $30 \mu \mathrm{g} / \mathrm{L}$, within 0.5 to 1 pore volumes of treatment and remained well below $30 \mu \mathrm{g} / \mathrm{L}$ thereafter (Figure 2.6). 

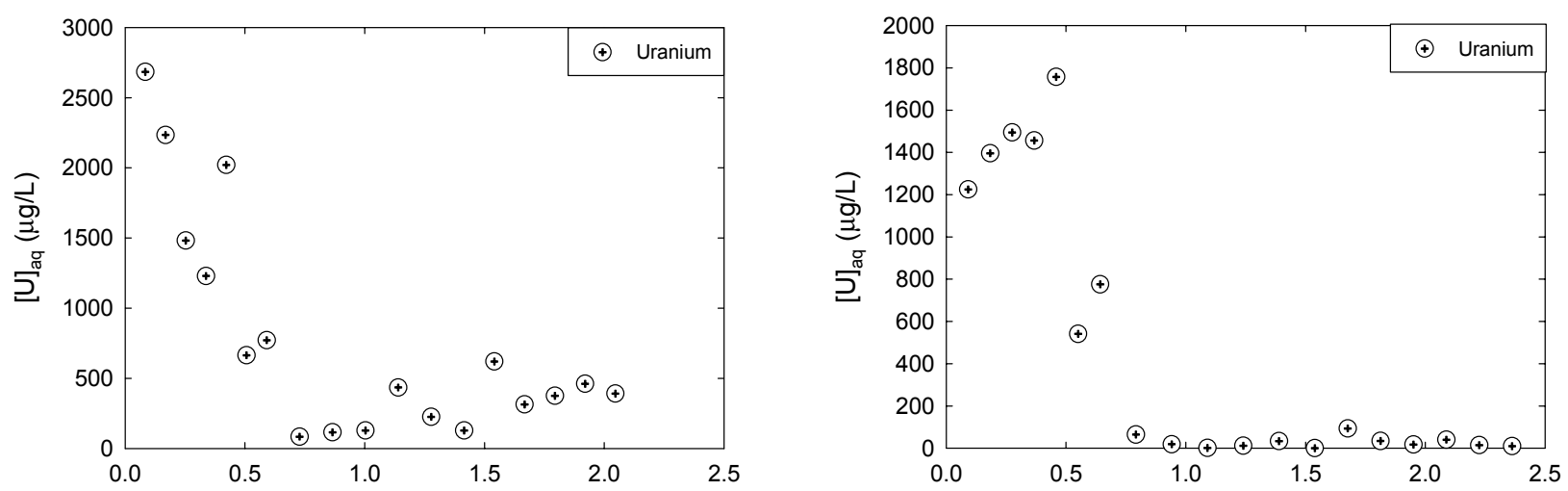

a.

b.
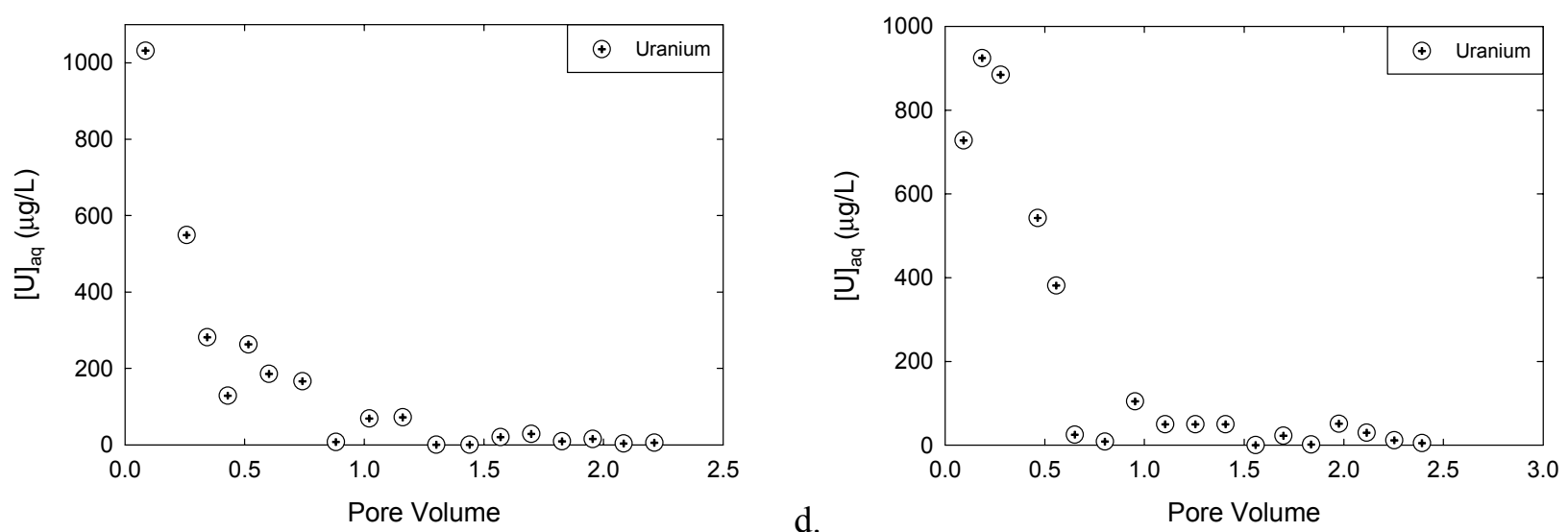

Figure 2.6. Graphs Depicting Aqueous Uranium Concentrations from Columns Saturated with $1,000 \mu \mathrm{g} / \mathrm{L}$ Uranium as a Function of the Number of Pore Volumes of Polyphosphate Remedy Displaced through Columns a) 11, b) 12, c) 13, and d) 14 (Table 2.4). Remedy injection order was phosphorus followed by calcium.

Columns 15 through 18 utilized the optimum formulations identified through previous tests (columns 13 and 14), as well as two additional formulations which contained equivalent total phosphorus concentrations, but maintained total calcium to phosphorus ratios of 1.9 (columns 17 and 18). The order of injection was altered for all columns (15 through 18), such that calcium was injected prior to phosphorus. Qualitative visual inspection of the columns following treatment suggests the most complete distribution within the column and removal of uranium occurred in column 16, which used a calcium to phosphorus ratio of 1.9 and $\mathrm{pH} 7$ (Figure 2.7). However, with the exception of column 17, quantitative analysis of effluent uranium concentrations did not decline as rapidly as those measured in the previous set of columns, 11 through 14, wherein phosphorus was injected first followed by calcium (Figure 2.9). Additionally, the efficacy and long-term performance of columns 15 through 18 is less than that of columns 11 through 14 where uranium concentrations remain well below $30 \mu \mathrm{g} / \mathrm{L}$. Aqueous uranium concentrations measured from columns 15 through 18 decline to below $30 \mu \mathrm{g} / \mathrm{L}$, but then exhibit a number of fluctuations above and below the MCL for uranium. It is hypothesized the instability of uranium in columns 15 through 18 is attributable to initial formation of calcium-uranate phases, which are highly soluble relative to uranium-phosphate phases. Upon injection of the phosphorus phase, the calcium-uranate phases likely undergo rapid dissolution to release soluble uranium that re-precipitates as uranium-phosphate. Although both injection schemes ultimately result in formation of uraniumphosphate, precipitation and dissolution of calcium-uranate phases may afford undesirable fluctuations in uranium concentration above $30 \mu \mathrm{g} / \mathrm{L}$. 


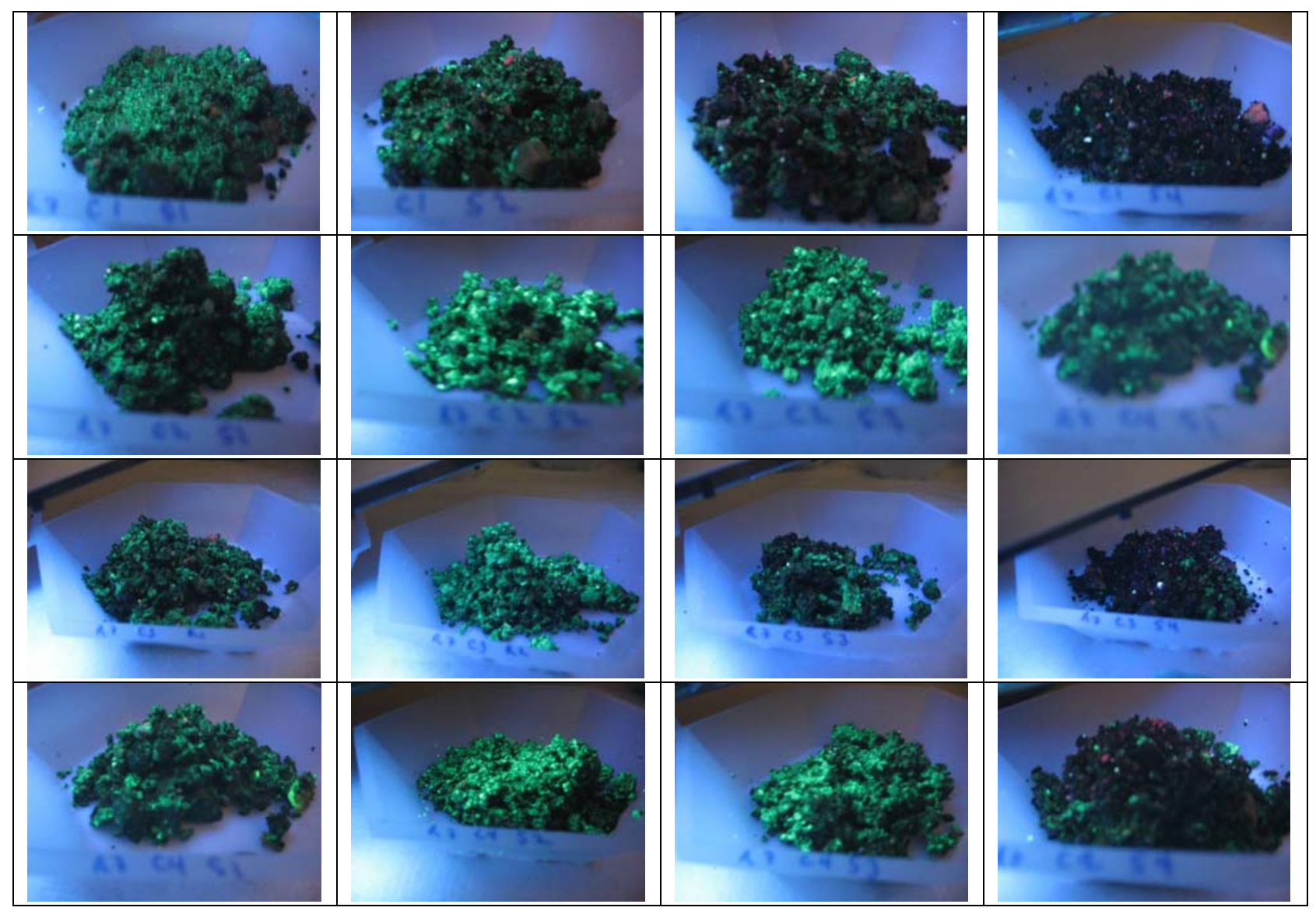

Figure 2.7. Photos of Columns Sections Taken Under Shortwave UV Radiation (orientation: top-down, columns 15 through 18; left to right, influent to effluent)

Irrespective of the injection order or concentration of phosphorus and calcium utilized in the amendment formulation, all phosphorus, including degradation products, was removed via sorption and precipitation reactions. Figure 2.8 illustrates a representative plot for the removal of phosphorus during treatment of uranium contaminant column testing, results are comparable for all column tests conducted.

Effluent concentrations of phosphorus are at or below background groundwater concentrations. Thus, the potential for down gradient transport and potential migration to the river is minimal. Additionally, phosphate readily precipitates cationic species as highly insoluble phases (Cotter-Howells and Caporn 1996;

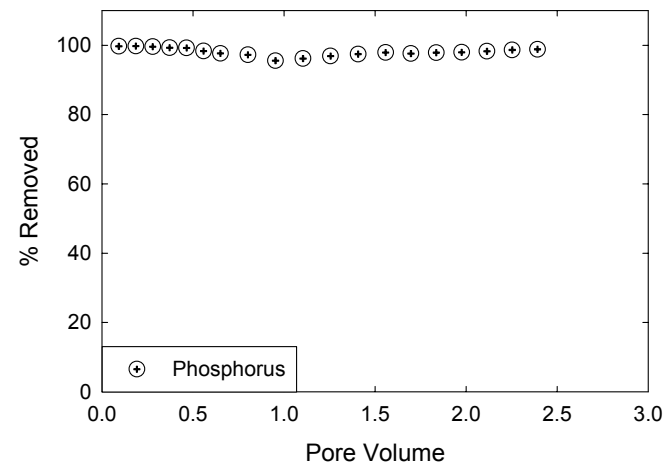

Figure 2.8. Representative Plot Depicting the Removal of Phosphorus via Sorption and Precipitations Reactions Griffith et al. 1973; Lindsay 1979; Lindsay and Moreno 1960; Nriagu and Moore 1984; Sparks and Hunger 2002). As such, there is minimal concern regarding mobilization of sedimentary components during treatment. Moreover, utilization of the polyphosphate amendment to control precipitation kinetics afforded no effect on the hydraulic conductivity of the sediment during column testing; therefore, no significant impact to the hydraulic conductivity of the aquifer is anticipated. 

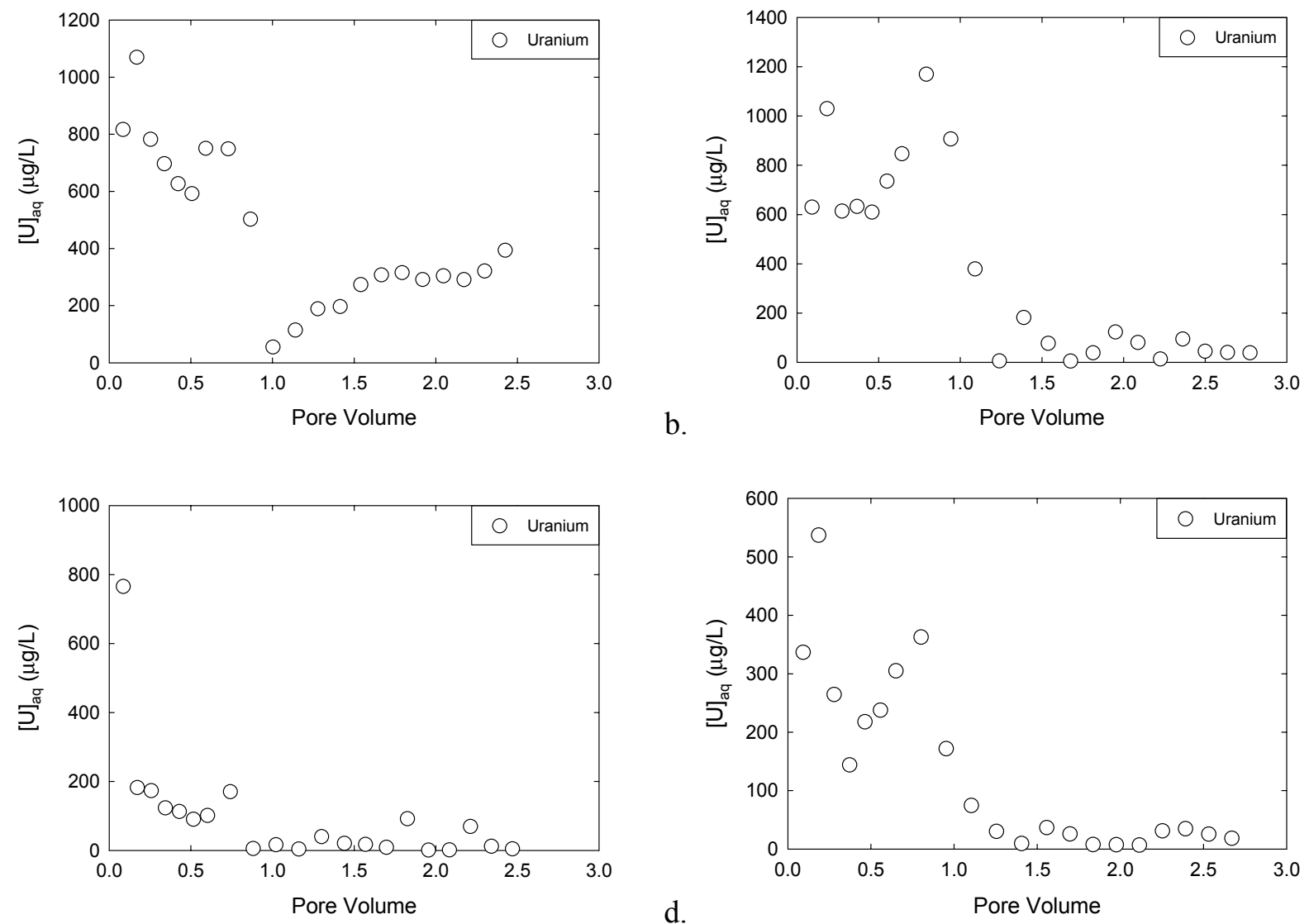

Figure 2.9. Graphs Depicting Aqueous Uranium Concentrations from Columns Saturated with $1,000 \mu \mathrm{g} / \mathrm{L}$ Uranium as a Function of the Number of Pore Volumes of Polyphosphate Remedy Displaced Through Columns a) 15, b) 16, c) 17, and d) 18 (Table 2.4). Remedy injection order was calcium followed by phosphorus.

\subsubsection{Transport}

Column experiments were conducted to quantify the mobility of ortho-, pyro-, and tripolyphosphate, individually and as a mixed formulation, to evaluate differences in retardation due to interaction between the various phosphate compounds and evaluate the mobility of calcium in order to determine the volume of amendment necessary to treat the desired zone. Saturated column tests were conducted with the $<2 \mathrm{~mm}$ sediment fraction from 300 Area cores. The conditions and measured parameters for all of the transport experiments are summarized in Table 2.5. Recovery (\%) reflects the percentage of solute recovered in the effluent. $R$ is the retardation factor analysis and $K_{\mathrm{d}}$ is the apparent distribution coefficient calculated from $R$. Transport experiments were conducted at a $v$ of $\sim 20 \mathrm{~cm} \mathrm{~h}^{-1}$.

The saturated column technique that was utilized here has been described elsewhere (Gamerdinger et al. 1994, 2001a, 2001b). Briefly, borosilicate glass column (length, $L=10.5 \mathrm{~cm}$, radius, $r=1.25 \mathrm{~cm}$; and bulk volume, $V_{b}=53.71 \mathrm{~cm}^{3}$ ) were packed uniformly with the $<2.00 \mathrm{~mm}$ fraction of sediment from cores collected from the 300 Area. The columns were saturated with Hanford groundwater until stable water content was attained; syringe pumps were used to control the flow rate. Sediment bulk density, 
Table 2.5. Transport Parameters Determined by Direct Measurement or from Laboratory Derived Breakthrough Curves on the $<2$ mm Sediment Fraction

\begin{tabular}{|c|c|c|c|c|c|c|c|c|}
\hline Expt. ${ }^{(a)}$ & $\begin{array}{c}F \\
\left(\mathrm{~cm}^{3} / \mathrm{hr}\right)\end{array}$ & $\begin{array}{c}\rho_{b} \\
\left(\mathrm{~g} / \mathrm{cm}^{3}\right)\end{array}$ & $\theta$ & $\begin{array}{c}V_{w} \\
(\mathrm{~mL})\end{array}$ & $\begin{array}{c}v \\
(\mathrm{~cm} / \mathrm{hr})\end{array}$ & $\begin{array}{c}t_{o} \\
\left(\mathrm{~V}_{\mathrm{w}}\right)\end{array}$ & $R$ & $\begin{array}{c}K_{\mathrm{d}} \\
(\mathrm{mL} / \mathrm{g})\end{array}$ \\
\hline Ortho & 30.37 & 1.478 & 0.386 & 20.89 & 16.01 & 11.22 & 5.54 & 1.19 \\
\hline Pyro & 41.93 & 1.444 & 0.385 & 20.33 & 22.18 & 15.90 & 7.61 & 1.76 \\
\hline Tripoly & 40.80 & 1.460 & 0.392 & 21.27 & 21.22 & 14.70 & 5.17 & 1.12 \\
\hline Calcium & 31.41 & 1.478 & 0.386 & 20.89 & 16.57 & 11.95 & 14.14 & 3.44 \\
\hline Amend 7 & 30.61 & 1.444 & 0.385 & 20.33 & 16.19 & 12.26 & 5.83 & 1.29 \\
\hline Amend & 30.88 & 1.460 & 0.392 & 21.27 & 16.05 & 11.82 & 5.23 & 1.13 \\
\hline
\end{tabular}

$\rho_{b}\left(\mathrm{~g} \mathrm{~cm}^{-3}\right)$, and volumetric water content, $\theta\left(\mathrm{cm}^{3} \mathrm{~cm}^{-3}\right)$, were determined from the mass of the sediment and/or water. The percent saturation was calculated from the ratio of $\theta$ (water-filled porosity), to the total porosity, $\phi$, which was calculated from the bulk density and particle density.

The results of transport in near-saturated columns for sodium ortho-, pyro-, tripolyphosphate, calcium, the phosphorus amendment formulation as mixed and the phosphorus amendment formulation $\mathrm{pH}$ adjusted to $\sim 7$ are shown in Figure 2.10. Note that columns were saturated until a stable water content was attained. Calculation of the percent saturation based on total porosity indicated that the conventional columns were approximately $90 \%$ saturated. A full breakthrough curve for sodium orthophosphate was attained and recovery of phosphorus in the effluent was $\sim 100 \%$ (Figure 2.10 ). Breakthrough curves (BTCs) for sodium pyro- and tripolyphosphate, conducted under the same conditions as sodium orthophosphate, only afforded $\sim 75 \%$ recovery of the influent pulse (Figure 2.10 ). Possible mechanisms that may have resulted in increased sorption are (i) sorption of degradation products onto sediment bound polymerized phosphate molecules, and/or (ii) degradation of polymerized phosphate compounds and subsequent sorption to the sediment matrix. This suggests the significance of reactions occurring between sodium ortho-, pyro-, and tripolyphosphate. In the absence of precipitation reactions (i.e., formation of calcium- and uranium-phosphate phases), the mobility of the phosphorus amendment is comparable to that of the individual phosphate compounds (Figure 2.10). The apparent retardation factor within the $<2 \mathrm{~mm}$ sediment fraction is 5.23 for the non-pH adjusted amendment and 5.83 for the $\mathrm{pH}$ adjusted amendment (Table 2.5). Correcting these values for field conditions assumed retardation was due to the $<2 \mathrm{~mm}$ fraction which comprised $\sim 10 \%$ of the total sediment matrix. Using a porosity value of 0.2 and bulk density of 2.19, the calculated field $K_{d}$ and retardation values are given in Table 2.6.

Figure 2.10 also displays the result of calcium transport under saturated conditions. Unlike the anionic phosphate species calcium is cationic and strongly retarded within the anionic sedimentary and aqueous conditions present within the Hanford 300 Area subsurface (Table 2.5). Injection of a calcium pulse required a greater number of pore volumes to be delivered in order to afford a $\mathrm{C} / \mathrm{C}_{\mathrm{o}}=1$. Moreover, the desorption, or later, half of the calcium BTC displayed prolonged tailing for more than 40 pore volumes without reaching zero. Correcting the retardation value for field conditions again assumed retardation was due to the $<2 \mathrm{~mm}$ fraction which comprised $\sim 10 \%$ of the total sediment matrix. Using a porosity value of 0.2 , the calculated field $K_{d}$ and retardation values are given in Table 2.6. 

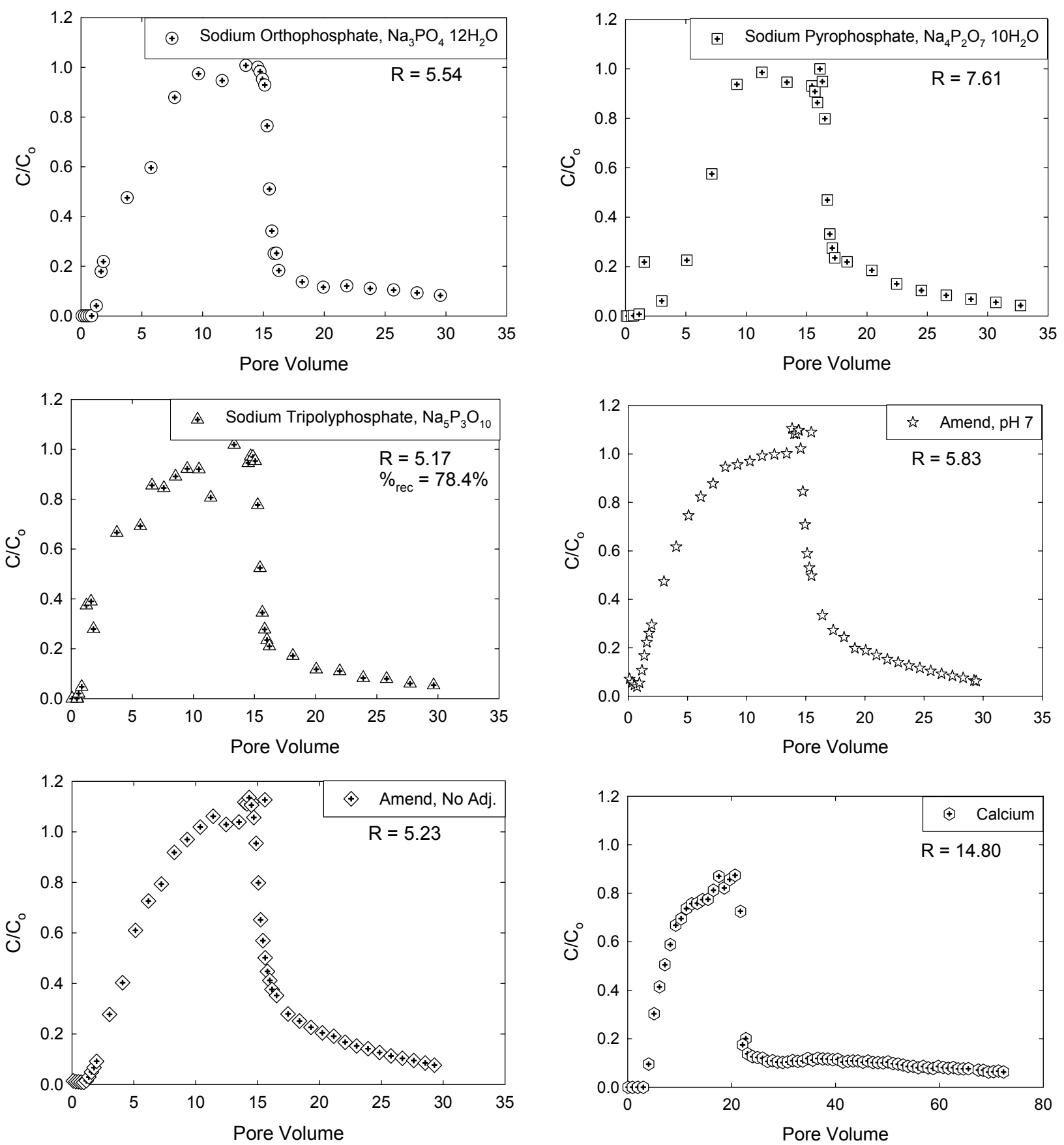

Figure 2.10. Breakthrough Curves for Sodium Ortho-, Pyro-, Tripolyphosphate, Calcium, the Phosphorus Amendment Formulation as Mixed, and the Phosphorus Amendment Formulation $\mathrm{pH}$ Adjusted to $\sim 7$

\subsubsection{Intermediate Scale Column Test}

An intermediate scale column test was conducted to demonstrate the efficacy of the final amendment formulation using the complete sedimentary size fraction from cores collected from the 300 Area. A PVC column (length, $\mathrm{L}=3.04 \mathrm{~m}$ [10 ft]; radius, $\mathrm{r}=10 \mathrm{~cm}$ [4 in.]) was packed uniformly with sediment from 
Table 2.6. Field Transport Parameters Calculated from Laboratory Derived Transport Parameters

\begin{tabular}{||c|c|c|c||}
\hline Compound & $\begin{array}{c}v \\
(\mathrm{ft} / \mathrm{d})\end{array}$ & $R$ & $\begin{array}{c}K_{\mathrm{d}} \\
(\mathrm{mL} / \mathrm{g})\end{array}$ \\
\hline \hline Sodium Orthophosphate & 53.18 & 2.30 & 0.12 \\
\hline Sodium Pyrophosphate & 74.88 & 2.93 & 0.18 \\
\hline Sodium Tripolyphosphate & 71.66 & 2.23 & 0.11 \\
\hline Calcium & 56.64 & 4.76 & 0.34 \\
\hline Amendment, pH 7 & 57.74 & 2.41 & 0.13 \\
\hline Amendment, no pH Adjustment & 57.61 & 2.24 & 0.11 \\
\hline
\end{tabular}

300 Area cores and saturated with Hanford groundwater to ensure chemical equilibrium. The column was saturated with Hanford groundwater until stable water content was attained; syringe pumps were used to control the flow rate. Sediment bulk density, $\rho_{b}\left(\mathrm{~g} \mathrm{~cm}^{-3}\right)$, and volumetric water content, $\theta\left(\mathrm{cm}^{3} \mathrm{~cm}^{-3}\right)$, were determined from the mass of the sediment and/or water. The percent saturation was calculated from the ratio of $\theta$ (water-filled porosity), to the total porosity, $\phi$, which were calculated from the bulk density and particle density. Preliminary characterization results indicated the uranium concentration within the aqueous and solid matrix of the sediment cores is below the MCL for uranium. As such, in order to effectively evaluate polyphosphate amendments for uranium remediation, it will be necessary to use a solution of Hanford groundwater spiked with aqueous uranium to saturate the column prior to amendment testing. The uranium concentration in the pore fluid will be 1,000 ppb. Aqueous effluent concentrations will be monitored via ICP-MS and ICP-OES. The formation of solid phases within the sedimentary matrix will be evaluated ex situ using fluorescence spectroscopy and XRD.

\subsubsection{Potential Adverse Impacts}

As describe in the preceding paragraphs, irrespective of the injection order or concentration of phosphorus and calcium used in the amendment formulation, all phosphorus, including degradation products, was removed via sorption and precipitation reactions (Figure 2.8); effluent concentrations of phosphorus are at or below background groundwater concentrations. Additionally, phosphate readily precipitates cationic species as highly insoluble phases (Cotter-Howells and Caporn 1996; Griffith et al. 1973; Lindsay 1979; Lindsay and Moreno 1960; Nriagu and Moore 1984; Sparks and Hunger 2002). Thus, the potential for downgradient transport and potential migration to the river is minimal; there is minimal concern regarding mobilization of sedimentary components during treatment. Moreover, utilization of the polyphosphate amendment to control precipitation kinetics afforded no effect on the hydraulic conductivity of the sediment during column testing; therefore, no significant impact to the hydraulic conductivity of the aquifer is anticipated.

\subsection{Polyphosphate Amendment}

Based on results from the column transport experiments discussed in Section 2.2, a three-phase injection strategy was identified as an effective approach to obtain both direct treatment of the uranium contamination in groundwater (i.e., autunite formation) and formation of the apatite mineral, which provides for long-term treatment capacity within the amended zone to address uranium solubilized and released from the smear zone during future high water table conditions. The three part injection strategy consists of the following:

- Initial polyphosphate amendment injection to precipitate aqueous uranium within the treatment zone as autunite. 
- The initial polyphosphate injection will be directly followed by injection of a calcium chloride $(\mathrm{CaCl})$ solution to provide a sufficient calcium source for apatite formation during a subsequent polyphosphate injection. Due to the higher $\mathrm{K}_{\mathrm{d}}$ of the $\mathrm{CaCl}$ solution as measured on site specific sediments, a larger injection volume will be required to reach the full radial extent of the targeted treatment zone for this component of the amendment formulation. However, this same increased retardation will help to facilitate mixing between the calcium and polyphosphate amendments during the third and final injection phase.

- The $\mathrm{CaCl}$ injections will be directly followed by a final polyphosphate injection.

Table 2.7 presents the final polyphosphate remediation amendment formulation. The solubility values listed in Table 2.7 were experimentally determined in tap water, filtered through a $0.45-\mu \mathrm{m}$ filter, at room temperature. Moreover, the values are not independent solubility values; rather, they are the maximum solubility within the total polyphosphate formulation. Results of batch and column tests demonstrated optimum performance is achieved using a formulation to which the contribution of phosphorus is $25 \%$ orthophosphate, $25 \%$ pyrophosphate, and $50 \%$ tripolyphosphate. The mixture of the various components of the polyphosphate solution will be used to achieve a solution $\mathrm{pH}$ of $\sim 7$. The amendment solution will be prepared by mixing, in order, the sodium orthophosphate, sodium pyrophosphate, and sodium tripolyphosphate to achieve a $\mathrm{pH}$ of 7 and prevent degradation of polymerized phosphate molecules during preparation of the remedy solution.

Table 2.7. Pilot-Scale Field Test Amendment Formulation

\begin{tabular}{|c|c|c|c|c|c|c|c|c|}
\hline Injection & Amendment & Formula & CAS \# & $\begin{array}{c}\text { Formula } \\
\mathrm{Wt} \\
(\mathrm{g} / \mathrm{mol}) \\
\end{array}$ & $\begin{array}{c}\text { Solubility, } \\
\text { g/L } 23^{\circ} \mathrm{C} \\
\mathrm{H}_{2} \mathrm{O} \\
\end{array}$ & $\begin{array}{c}\text { Density, } \\
\mathrm{g} / \mathrm{cm}^{3} \\
\left(25^{\circ} \mathrm{C}\right)\end{array}$ & $\begin{array}{l}\text { Conc. } \\
(\mathrm{g} / \mathrm{L})\end{array}$ & $\begin{array}{l}\text { Conc. } \\
(\mathrm{M})\end{array}$ \\
\hline \multirow[t]{4}{*}{1} & \begin{tabular}{|l} 
Sodium \\
Phosphate, \\
monobasic
\end{tabular} & $\mathrm{NaH}_{2} \mathrm{PO}_{4}$ & $7558-80-7$ & 119.98 & 29.63 & \multirow[t]{4}{*}{1.004} & 0.59 & $4.94 \times 10^{-3}$ \\
\hline & \begin{tabular}{|l|} 
Sodium \\
Pyrophosphate
\end{tabular} & $\mathrm{Na}_{4} \mathrm{P}_{2} \mathrm{O}_{7}$ & $7722-88-5$ & 265.9 & 32.81 & & 0.66 & $2.47 \times 10^{-3}$ \\
\hline & $\begin{array}{l}\text { Sodium } \\
\text { Tripolyphosphate }\end{array}$ & $\mathrm{Na}_{5} \mathrm{P}_{3} \mathrm{O}_{10}$ & $7758-29-4$ & 367.86 & 60.40 & & 1.21 & $3.29 \times 10^{-3}$ \\
\hline & Sodium Bromide & $\mathrm{NaBr}$ & & 102.90 & & & 0.103 & $1.00 \times 10^{-3}$ \\
\hline 2 & Calcium Chloride & $\mathrm{CaCl}_{2}$ & $10043-52-4$ & 110.98 & 800 & 1.005 & 3.41 & $3.07 \times 10^{-2}$ \\
\hline \multirow[t]{4}{*}{3} & $\begin{array}{l}\text { Sodium } \\
\text { Phosphate, } \\
\text { monobasic }\end{array}$ & $\mathrm{NaH}_{2} \mathrm{PO}_{4}$ & $7558-80-7$ & 119.98 & 29.63 & \multirow[t]{4}{*}{1.004} & 0.59 & $4.94 \times 10^{-3}$ \\
\hline & $\begin{array}{l}\text { Sodium } \\
\text { Pyrophosphate }\end{array}$ & $\mathrm{Na}_{4} \mathrm{P}_{2} \mathrm{O}_{7}$ & $7722-88-5$ & 265.9 & 32.81 & & 0.66 & $2.47 \times 10^{-3}$ \\
\hline & \begin{tabular}{|l|} 
Sodium \\
Tripolyphosphate
\end{tabular} & $\mathrm{Na}_{5} \mathrm{P}_{3} \mathrm{O}_{10}$ & $7758-29-4$ & 367.86 & 60.40 & & 1.21 & $3.29 \times 10^{-3}$ \\
\hline & Sodium Bromide & $\mathrm{NaBr}$ & & 102.90 & & & 0.103 & $1.00 \times 10^{-3}$ \\
\hline
\end{tabular}




\subsection{Performance and Data Quality Objectives}

This section identifies the treatability test performance objectives and the associated data quality objectives necessary to meet the performance objectives.

\subsection{Test Performance Objectives}

The overall objectives of the treatability test include the following:

- Conduct a polyphosphate injection to evaluate reduction of aqueous uranium concentrations and to determine the longevity of treatment of the process at field scale.

- Conduct field scale application of polyphosphate injection to evaluate whether a full-scale process can be implemented.

- Determine the number of wells, reagent concentrations, volumes, injection rates, operational strategy, and longevity for polyphosphate injections for remediating uranium such that costs for full-scale application can be effectively estimated.

\subsection{Data Quality Objectives}

This section summarizes the decisions that will be addressed by the uranium stabilization through polyphosphate injection treatability test. Table 3.1 shows the key decisions for evaluating the polyphosphate injection and the type of data that will be collected to address these items. These data items are incorporated into the field test operation herein and associated Sampling and Analysis Plan (Section 7) that guide how the test will be conducted.

\subsection{Analysis Requirements and Comparison Levels}

The 300 Area polyphosphate treatability test is being conducted at the south end of the 316-5 Process Trenches. This waste site received liquid waste containing uranium from 1975 to 1985 and is a known source for groundwater contamination. Liquid discharge to the trenches ceased in 1994. The remedial action objective for addressing uranium contamination in groundwater beneath the 300 Area is to reduce concentrations to meet the drinking water standard of $30 \mu \mathrm{g} / \mathrm{L}$ (DOE 2005). With the seasonal variability of aqueous uranium concentrations in the 300 Area (Peterson 2005), post-test uranium concentrations in the injection well (399-1-23) and the surrounding monitoring wells will be compared to the drinking water standard, baseline levels measured in these wells prior to the polyphosphate injections, and historical concentrations measured in this area from surrounding wells.

Three rounds of baseline samples will be collected from these wells during the site characterization (see Section 6). Following treatment, a minimum of three performance assessment sampling events will be conducted. The first sampling event will occur within one month of treatment and subsequent samples will be collected on a monthly basis for at least two months. Based on the distribution of amendments observed during the injection test, a subset of site monitoring wells will be selected for performance assessment monitoring. If these observational data indicate fewer wells can be used to meet this monitoring objective, additional performance assessment sampling events will be performed. In addition, longer-term monitoring of the injection well and nearby monitoring wells will be conducted by the Hanford Site Groundwater Monitoring Project as part of their routine 300-FF-5 monitoring. 
Table 3.1. Uranium Stabilization through Polyphosphate Injection Key Decisions

\begin{tabular}{|c|c|c|c|}
\hline $\begin{array}{l}\text { Primary } \\
\text { Objective }\end{array}$ & Decision & $\begin{array}{c}\text { Detailed } \\
\text { Sub-Objectives }\end{array}$ & Data for Analysis \\
\hline \multirow[t]{4}{*}{$\begin{array}{l}\text { Design } \\
\text { Barrier }\end{array}$} & \multirow{4}{*}{$\begin{array}{l}\text { Barrier } \\
\text { Dimensions } \\
\text { and well } \\
\text { spacing } \\
\text { requirements }\end{array}$} & $\begin{array}{l}\text { Radial influence of } \\
\text { treatment }\end{array}$ & $\begin{array}{l}\text { Tracer, conductance, phosphate, and calcium } \\
\text { breakthrough at monitoring wells assessed at different } \\
\text { radial distances; laboratory testing of phosphate minerals } \\
\text { on sediment samples from post-injection test boreholes. }\end{array}$ \\
\hline & & $\begin{array}{l}\text { Rate and extent of } \\
\text { uranium concentration } \\
\text { reduction }\end{array}$ & $\begin{array}{l}\text { Uranium concentrations at monitoring wells at } \\
\text { difference distances from injection well compared with } \\
\text { baseline and upgradient concentrations }\end{array}$ \\
\hline & & Treatment longevity & $\begin{array}{l}\text { Hydraulic gradient, aquifer hydraulic conductivity and } \\
\text { tracer transport response at monitoring wells to } \\
\text { determine groundwater flow direction and velocity; } \\
\text { column studies using sediment samples collected from } \\
\text { the treatment zone to access autunite/apatite formation. }\end{array}$ \\
\hline & & $\begin{array}{l}\text { Required overlap of } \\
\text { injections to form a } \\
\text { barrier }\end{array}$ & $\begin{array}{l}\text { Tracer, electrical conductance, phosphate, and calcium } \\
\text { breakthrough at monitoring wells at various radial } \\
\text { distances; analyzed with numerical model to estimate } \\
\text { total radial extent of treatment and evaluate well spacing } \\
\text { requirements. }\end{array}$ \\
\hline \multirow[t]{6}{*}{$\begin{array}{l}\text { Evaluate } \\
\text { Barrier } \\
\text { Performance }\end{array}$} & \multirow[t]{2}{*}{$\begin{array}{l}\text { Injection } \\
\text { Performance }\end{array}$} & $\begin{array}{l}\text { Spatial distribution of } \\
\text { phosphate mineral } \\
\text { formation }\end{array}$ & $\begin{array}{l}\text { Tracer, conductance, phosphate, and calcium } \\
\text { breakthrough at monitoring wells in different radial } \\
\text { locations assessed for uniformity and distance }\end{array}$ \\
\hline & & $\begin{array}{l}\text { Injection pressure and } \\
\text { flow rate }\end{array}$ & Process data monitored during injection \\
\hline & \multirow[t]{2}{*}{$\begin{array}{l}\text { Barrier } \\
\text { Performance }\end{array}$} & $\begin{array}{l}\text { Treatment effectiveness } \\
\text { and longevity }\end{array}$ & $\begin{array}{l}\text { Hydraulic gradient, aquifer hydraulic conductivity and } \\
\text { tracer transport response at monitoring wells to } \\
\text { determine groundwater flow direction and velocity; } \\
\text { column studies using sediment samples collected from } \\
\text { the treatment zone to access autunite/apatite formation. }\end{array}$ \\
\hline & & $\begin{array}{l}\text { Rate and extent of } \\
\text { uranium concentration } \\
\text { reduction }\end{array}$ & $\begin{array}{l}\text { Uranium concentrations at monitoring wells at } \\
\text { difference distances from injection well compared with } \\
\text { baseline and upgradient concentrations }\end{array}$ \\
\hline & \multirow{2}{*}{$\begin{array}{l}\text { Potential } \\
\text { Adverse } \\
\text { Impacts }\end{array}$} & $\begin{array}{l}\text { Aquifer plugging in } \\
\text { barrier }\end{array}$ & $\begin{array}{l}\text { Hydraulic property test before and after barrier } \\
\text { installation. }\end{array}$ \\
\hline & & Impact on water quality & $\begin{array}{l}\text { Water quality parameter monitoring before and after } \\
\text { barrier installation. }\end{array}$ \\
\hline $\begin{array}{l}\text { Economic } \\
\text { Feasibility }\end{array}$ & $\begin{array}{l}\text { Economic } \\
\text { Evaluation }\end{array}$ & $\begin{array}{l}\text { Design, installation, } \\
\text { operation/re-injection } \\
\text { costs }\end{array}$ & $\begin{array}{l}\text { Reagent quantities, equipment and material requirements, } \\
\text { and labor requirements for installation and maintenance } \\
\text { of the barrier. }\end{array}$ \\
\hline
\end{tabular}

In addition to aqueous sampling, treatment efficiency and treatment zone longevity will be assessed through laboratory analysis of post-treatment sediment core samples collected from the amended zone. A detailed discussion of both aqueous and sediment sampling and analysis is provided in Section 7. 


\subsection{Compliance with Applicable or Relevant and Appropriate Requirements}

In accordance with the EPA's Guide to Conducting Treatability Studies Under CERCLA (EPA 1992), onsite treatability tests may be conducted without any federal, state, or local permits (40 CFR 300.400 [e][1]); however, such studies must meet applicable or relevant and appropriate requirements (ARARs) under federal or state environmental laws or be exempted by a waiver under Comprehensive Environmental Response, Compensation, and Liability Act (CERCLA) Section 121(d)(4).

The treatability test will be conducted in the 300-FF-5 Groundwater Operable Unit with the EPA as the lead regulatory agency of this operable unit as described in the Hanford Federal Facility Agreement and Consent Order (Ecology et al. 1989). Should unforeseen conditions warrant, EPA (as the responsible regulatory agency in consultation with DOE Richland Operations Office [RL]) has the authority to terminate the treatability test.

The polyphosphate treatability test will occur $\sim 300 \mathrm{~m}(984 \mathrm{ft})$ inland from the Columbia River in an area that is not expected to be culturally and ecologically sensitive. The test requires the construction of groundwater wells. The test also has the potential to generate waste and wastewater. The major ARARs pertinent to this treatability test are groundwater standards, Columbia River protection standards, cultural and ecological resource protection requirements, and waste and wastewater management standards.

\subsection{Groundwater Standards}

Contaminated groundwater currently discharges to the Columbia River from the uranium contaminated aquifer. Uranium and other water quality measurements will be used to evaluate the effectiveness of the polyphosphate process and to evaluate potential side effects. This evaluation will be made by comparing these measured concentrations to water quality standards for groundwater (WAC 173-200) and to the Freshwater Toxics Criteria Concentration (40 CFR 131.36). Monitoring of water quality parameters ( $\mathrm{pH}$, Eh, electrical conductivity, and dissolved oxygen), major ions, and trace metals within and downgradient of the test site is planned as part of this study to evaluate potential side effects. A complete list of analytes, analyses methods, and detection limits is included in Section 7.

The polyphosphate treatability test will inject sodium, phosphate species (orthophosphate, pyrophosphate, and tripolyphosphate), calcium, bromide, and chloride as detailed in Table 2.7. The attenuation of the downgradient residual plume is expected to occur from a number of processes, including: precipitation reactions, adsorption, diffusion, and dispersion. Due to the relatively small scale of the test, no significant, long-term adverse effects on the water quality downgradient of the treatability test site in the 300 Area are anticipated.

Based on the injection concentrations shown in Table 2.7, the concentration of chloride for injection \#2 is 2,180 mg/L which will exceed the 250-mg/L EPA National Secondary Drinking Water Standards and Washington State Secondary Ground Water Quality Criteria (WAC 173-200) for a limited period of time in the aquifer at the polyphosphate treatability test site. Ambient water quality standards for non-priority pollutants for chloride are $860 \mathrm{mg} / \mathrm{L}$ (acute) and $230 \mathrm{mg} / \mathrm{L}$ (chronic) set by the EPA and adopted by Washington State (WAC 173-201A). It is expected that a least a 10 fold decrease in the injection concentration will occur by the time the chloride plume reaches the Columbia River due to 
dispersion and diffusion. A 10X decrease in the concentration would reduced the chloride concentrations below the ambient water quality standards. During the bromide tracer test conducted at the treatability test site in December, 2006 concentrations detected in the furthest downgradient monitoring well (well

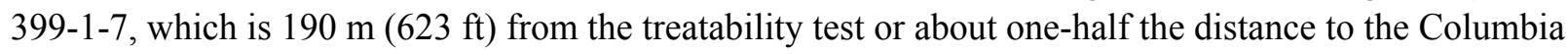
River) saw a maximum of $\sim 6 \%$ of the injected bromide tracer concentration. A complete description of the tracer test is contained in Section 6.3. Chloride concentrations will be monitored in wells downgradient from the test as part of the treatability study to assess the attenuation of this transient plume. Mean baseline chloride concentrations at the site monitoring wells from the first round of baseline samples was $19.7 \mathrm{mg} / \mathrm{L}$ (see Section 6.5).

Total dissolved solids (TDS) will also be elevated above National Secondary Drinking Water Standards level of $500 \mathrm{mg} / \mathrm{L}$ in the aquifer at the site following the injection. The TDS of injections \#1 and \#3 (Table 2.7) is approximately $2,560 \mathrm{mg} / \mathrm{L}$ and injection $\# 2$ is $3,410 \mathrm{mg} / \mathrm{L}$. Similar to the chloride discussed above, the TDS plume is expected to significantly attenuate downgradient of the site due to dispersion and diffusion along with additional attenuation of the TDS due to sorption and precipitation reactions. Other constituents in the injection concentrations (Table 2.7) are not listed in the drinking water or ambient water quality standards. Additionally, with the exception of chloride and the bromide tracer, these constituents will react with the groundwater contaminants and aquifer sediments and are not expected to travel significant distances from the treatability test site.

Although groundwater quality in the immediate vicinity of the injection well, and to a lesser extent downgradient of the treatment, will be impacted, this treatability test evaluating the potential for uranium stabilization through polyphosphate injection will meet the substantive requirements of WAC 173-218.

\subsection{Columbia River Protection Standards}

Technology-based limitations and standards, control of toxic pollutants, and monitoring for discharges to waters of the United States, including storm water, are addressed in 40 CFR 122. The Hanford Reach Study Act is applicable to planning, designing, and locating activities in a manner that minimizes direct and adverse effects on the values for which the river is under study. The treatability test will be conducted inside the 0.4-km (0.2-mi) limit of the Columbia River. However, because this site is located well south of the Hanford Reach National Monument boundary, this regulation will not apply and notification or approval from the U.S. Fish and Wildlife Service will not be required.

\subsection{Cultural and Ecological Resource Protection Standards}

Cultural resource protection requirements apply because of the potential presence of significant archeological sites or artifacts in the 100-D Area. An initial cultural resource survey was performed as part of previous similar activities in the area (e.g., the LFI) and a site specific survey was conducted at the polyphosphate field test site as part of the initial drilling and site characterization (Vermeul et al. 2006). The National Historic Preservation Act is applicable and requires federal agencies to take into account the effect of an activity on any significant cultural resource. The National Archeological and Historical Preservation Act is applicable and requires action to recover and preserve artifacts in areas where activity may cause irreparable harm, loss, or destruction of significant artifacts.

The Endangered Species Act prohibits activities that threaten the continued existence of listed species or destroy critical habitat. The Migratory Bird Treaty Act is applicable to protection of migratory 
birds in the areas. The State of Washington implements the Bald Eagle Protection Act under the WAC 232-12-292. These rules are applicable due to the known roosting of bald eagles along the Columbia River. The part of the 300 Area around the polyphosphate treatability test site has been an active construction site the past few years due to remediation and demolition activities by Washington Closure. A site-specific survey was conducted at the polyphosphate field test site as part of the drilling authorization requirements.

\subsection{Waste and Wastewater Management Standards}

All treatability test residuals will be evaluated and managed in compliance with appropriate waste regulations. WAC 173-303 requires the identification and appropriate management of dangerous wastes. WAC 173-304 requires the identification and appropriate management of solid wastes that are not dangerous wastes. Solid wastes generated during the test (i.e., drill cuttings) will be disposed of, as required, at the Environmental Restoration Disposal Facility (ERDF), which is designed to meet the substantive standards for disposal of solid and dangerous wastes. Purgewater generated during development, aquifer testing, and sampling of these wells will be managed per Hanford Site requirements. Pacific Northwest National Laboratory (PNNL) will work with Fluor Hanford, Inc. to arrange for the transport and appropriate disposal of all investigation derived waste. 


\subsection{Conceptual Design and Site Setup}

This section outlines the conceptual design of the polyphosphate treatability test for uranium stabilization in groundwater beneath the Hanford 300 Area. This design, related information, and testing procedures will be refined based on results from large-scale column experiments and ongoing injection design analyses.

\subsection{Treatability Test Approach}

The general treatability testing approach consists of initial site characterization and setup, a polyphosphate injection test, and post-treatment performance assessment. The initial field site preparation involves well drilling, site characterization (hydraulic testing, tracer tests, baseline monitoring), and site setup (mobile laboratory setup, installing pumps and pressure transducers in monitoring wells, injection and sampling equipment). These activities are described in Section 6. In addition to these activities, bench-scale studies with site sediment were conducted to develop an effective chemicals formulation for the polyphosphate amendments and evaluate the transport properties of the amendments under site conditions (see Section 2).

As described in Section 2, the polyphosphate injection will be conducted in three separate phases: (1) polyphosphate amendment injection, (2) calcium chloride injection, and (3) another polyphosphate amendment injection.

Following this series of injections, post-treatment performance will be evaluated from analysis of aqueous samples collected from site wells along with laboratory experiments of sediment collected from the treatment zone to determine the distribution autunite and apatite mineral phase content created during the treatment.

\subsection{Treatability Test Activities}

Field-scale treatability testing of uranium stabilization through polyphosphate injection at the 300 Area is divided into six tasks as follows: (1) Project Management, (2) Bench-Scale Testing, (3) Site Characterization and Setup, (4) Pilot-Scale Injection Test, (5) Performance Assessment Monitoring, and (6) Data Analysis and Reporting. Each task is described in the following sections. Project-controlled field test instructions will be prepared prior to field work to describe details of specific field activities as noted below.

\section{Task 1: Project Management}

Subtask 1a-Project Support. This element is to plan, organize, and provide top-level guidance and direction for overall project performance. This task also provides for management of subcontracts and work orders associated with conducting the field work (e.g., drilling support). Project-level cost and schedule control, tracking, and reporting, and coordination with the Columbia River Protection Supplemental Technologies Project work scope through DOE-RL, the Groundwater Remediation and Closure Assessment Project, and the DOE Office of River Protection are included in this element. 
Subtask $1 b$ - Planning and Test Plan Preparation. This work element consists of reviewing available site hydrogeologic and geochemical data, refining the site conceptual model, developing both a laboratory-scale experimental approach and a field-scale treatability testing approach, and preparing planning documents. An experimental plan was prepared at the beginning of the project to cover benchscale laboratory testing. An initial site characterization plan was developed for the installation of the initial set of test site wells and describes the planned site characterization (Vermeul et al. 2006). This polyphosphate treatability test plan documents results of bench-scale testing and site characterization activities and provides a description of the technical approach and functional requirements of the polyphosphate treatability test. The final operational details of the treatability test will be described in field instructions prior to the test. Each plan will provide a description of planned testing activities, sampling and analysis methods, and data quality requirements.

\section{Task 2: Bench-Scale Laboratory Testing}

Bench-scale tests were conducted using batch and small- to intermediate-scale column experiments. Technical issues that will be evaluated include the use of multi-length polyphosphate chains and their hydrolysis rates, physical properties and transport behavior of chemical species used in the amendment, kinetics of autunite and apatite formation, and long-term immobilization of uranium by apatite. All experiments were conducted with sediments from the 300 Area and groundwater to make certain testing conditions are representative of the remediation area. Preliminary results for these experiments are described in Section 2.

\section{Task 3: Site Setup and Baseline Characterization}

This work element includes installation of test site monitoring wells and associated site-specific characterization, test systems design and setup. Data collected during the 300 Area LFI (Williams et al. 2007) was used to refine the hydrogeologic and geochemical conceptual model and select the most appropriate site for a field-scale demonstration of polyphosphate treatment. Data collected during the LFI investigation included geologic logging, geophysical logging, and depth discrete characterization of sediment physical properties, hydraulic properties, aqueous uranium concentration, and uranium concentrations sorbed to the sediment. LFI well 399-1-23 was selected as the injection well for the polyphosphate treatability study. Operational monitoring wells were installed around the injection well in November and December 2006 (Williams 2007; see Figures 1.2 and 1.3). Additional downgradient monitoring wells will be installed to monitor downgradient transport of the polyphosphate amendment in May 2007, prior to the polyphosphate injection. The site setup and preliminary characterization results, including hydraulic testing and a tracer injection test, are provided in Section 6.

\section{Task 4: Pilot-Scale Treatability Test}

This work element includes development of an injection design for the field test and conducting the pilot-scale field test. The injection design analysis incorporates results from the laboratory experimentation and site specific characterization activities.

- Injection Design Analysis. A groundwater flow and transport model, which was initially developed to support the 300-FF-5 feasibility study, provided a basis for developing a refined model of flow and transport at the scale of the proposed treatability test. This design tool will incorporate both benchscale experimental results and site-specific characterization data and will be used to evaluate the various geohydrologic, geochemical, and polyphosphate reaction mechanisms that control 
emplacement of a polyphosphate amended treatment zone. The model will be used as a design tool during development of the polyphosphate injection strategy.

- Polyphosphate Injection. Based on bench-scale experimental results, site specific characterization, and subsequent treatment zone emplacement design analyses, a pilot-scale field test of the technology will be conducted at the test site during high water-table conditions in June 2007. Operational parameters (volumes, rates, and concentrations), constituents/field parameters monitored, and sampling frequency will be determined based on ongoing injection design analysis and will be documented in a project specific field test instruction prior to conducting the field test. Monitoring data collected during the polyphosphate injection test will be used to assess the areal extent of treatment and determine where performance assessment samples are collected.

As discussed in Section 2.3, a three-phase injection strategy was identified as an effective approach for obtaining both direct treatment of the uranium contamination in groundwater (i.e., autunite formation) and formation of the apatite mineral, which provides for long-term treatment capacity within the amended zone to address uranium solubilized and released from the smear zone during future high water table conditions. This three part injection strategy consists of an initial polyphosphate amendment injection, followed by a calcium chloride injection, and followed up with a second polyphosphate amendment injection.

The polyphosphate formulation is provided in Table 2.7. Based on this specified formulation and the injection design analysis presented in Section 6.6, the total amendment chemical requirements are presented in Section 6.7. As indicated in Table 2.7, $\mathrm{NaBr}$ will be added to the polyphosphate amendment. This component of the polyphosphate amendment formulation provides a conservative tracer that can be monitored to assess the degree of phosphate retardation during the injection. Likewise, during the $\mathrm{CaCl}$ injection phase, the chloride ion will be tracked to assess the degree of calcium retardation during this phase of the injection.

\section{Task 5: Performance Assessment Monitoring}

Groundwater samples will be collected and analyzed to evaluate treatment performance. Hydraulic tests will be conducted following emplacement of the treatment zone and compared with pre-treatments values to assess the impact of treatment on aquifer hydraulic properties. Following the polyphosphate injection, boreholes will be drilled in the treatment zone and sediment samples collected for laboratory analysis treatment effectiveness.

- Groundwater Analyses. Inductively couple plasma - mass spectrometry (ICP-MS), inductively couple plasma - optical emission spectrometry (ICP-OES), and ion chromatography (IC) will be used for quantifiable aqueous cation and anion analyses before, during, and following deployment of the polyphosphate amendment. This will allow changes in aqueous concentrations, and speciation, due to amendment implementation to be tracked and correlated with the formation of solid phases within the sediment.

- Post-Treatment Hydraulic Testing. Hydraulic tests will be conducted following emplacement of the treatment zone and compared with pre-treatments values to assess the impact of treatment on aquifer hydraulic properties. Specifically, pre- and post-treatment hydraulic responses will be compared to determine whether any degree of aquifer plugging occurred. 
- Post Treatment Column Studies. Column studies will be conducted on sediment cores extracted from the remediation area following treatment to quantify the efficacy of the polyphosphate amendment for the immobilization of uranium. ICP-MS, ICP-OES, IC will be used for quantifiable aqueous cation and anion analyses.

- Sediment Analyses. Sediments will be characterized to determine basic chemical characteristics of the sediments as well as the solid phases of uranium present. Major elements in the sediments, including total uranium will be measured by $x$-ray fluorescence (XRF), fluorescence spectroscopy will be utilized to identify uranium minerals which will be collected via mechanical separation, $\mathrm{x}$-ray diffraction (XRD) and scanning electron microscopy-energy dispersive spectroscopy (SEM-EDS) will be utilized to identify precipitated uranium phases. The semi-selective chemical extraction technique (Tessier et al. 1979, with modifications) will be used to determine the percentage of uranium present in the extractable phases of water soluble, cation-exchangeable, carbonate solid bearing compounds; amorphous oxides; organic matter; crystalline $\mathrm{Fe}[\mathrm{III}]$ oxides; and strong acid leachable compounds. The residual uranium content in the remaining bulk sediment will be measured by XRF.

\section{Task 6: Data Analysis and Reporting}

This work element consists of managing, compiling, and evaluating all of the data generated during the treatability studies and preparing a treatability test report. The final report will cover activities ranging from basic laboratory development work through a field scale demonstration of the technology. Findings presented in this report will form the basis of an evaluation of this technology for remedial design/remedial action $(\mathrm{RD} / \mathrm{RA})$ testing.

\subsection{Setup and Instrumentation of Field Test Site}

This section includes a description of the site location, site utilities, injection equipment, chemical delivery, monitoring equipment, analytical equipment, and the integration of these components into the operational system required to conduct the polyphosphate injection. PNNL will work with Flour Hanford Inc., to arrange for site access, removal and installation of necessary pumps in wells, and waste water removal. All site utilities and all the required operational and monitoring equipment for the testing are supplied by PNNL.

\subsubsection{Site Location and Utilities}

The polyphosphate treatability test site is located around well 399-1-23 (see Figure 1.2). Figure 5.1 shows a photograph of the site setup with the wells, purgewater tanks, and sampling and process trailers. A 30-amp electrical circuit was available at the injection test site on an existing panel. This is sufficient power to operate all the sampling and monitoring equipment, the laboratory trailer, and the process trailer. A diesel generator will be properly sized and used to operate the extraction pump, the pump used for the chemical injection, and flood lamps for night time use.

The injection monitoring site contains an exclusion zone where no unauthorized personal are allowed to enter this area. The area contains sampling lines, cabling for water level and measurement, sampling pump control lines, and the make-up water feed line. The laboratory trailer is located just outside this exclusion zone. The sampling manifold and other sampling equipment is located in the lab trailer. All water-level measurement cabling is routed into this trailer for real time observations of this data during testing. An additional trailer is located in the exclusion zone and contains a make up water injection 
manifold, polyphosphate injection system, and Campbell data logger readouts for flow rates through the manifold. Three 1,892 L (500 gal) tanks are located out of the exclusion zone for purge water storage.

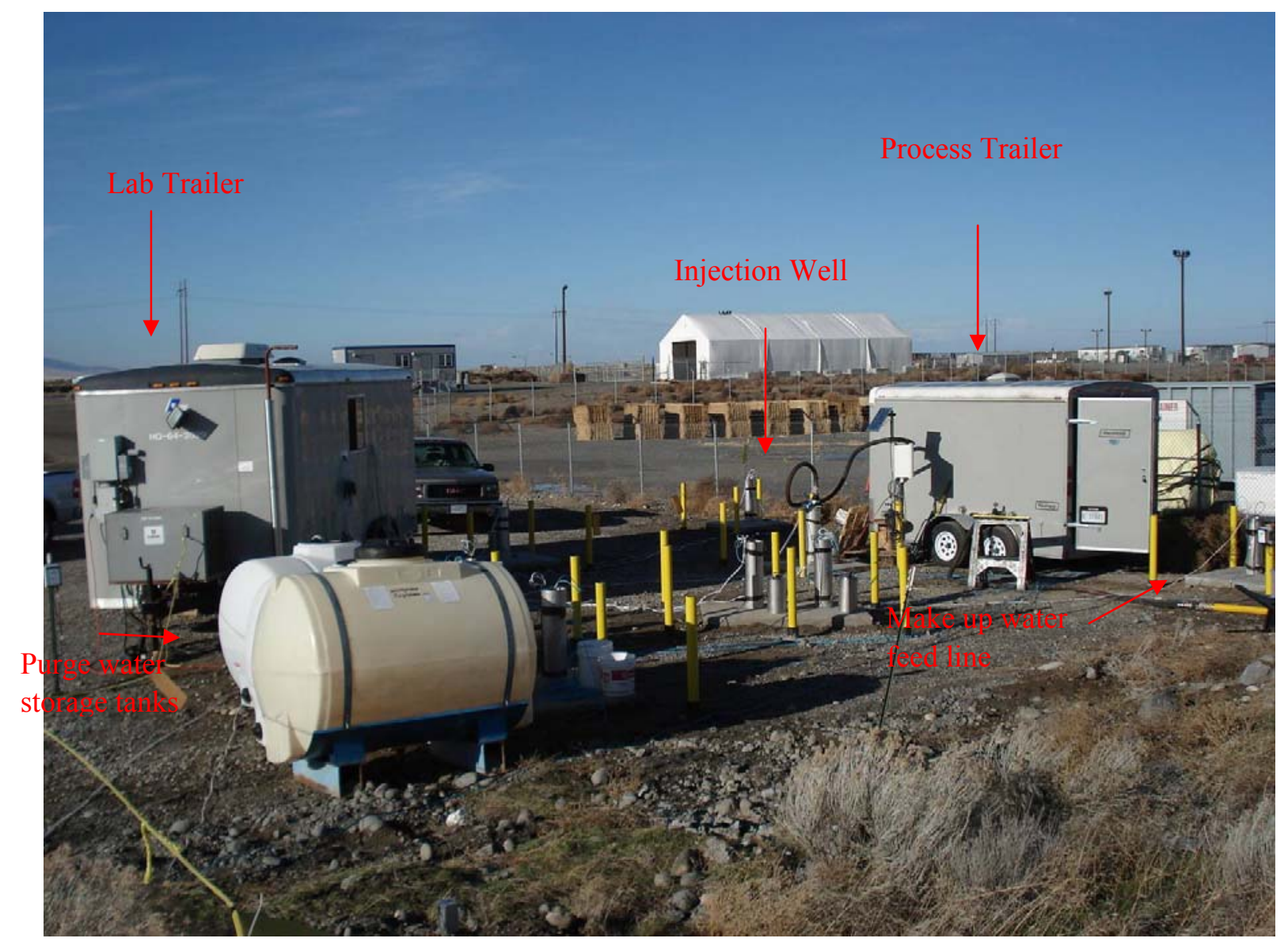

Figure 5.1. Site Layout Centered Around the Injection and Monitoring Wells

\subsubsection{Water Supply}

To accomplish a constant rate injection test, a substantial supply of water is needed. It is estimated that over 3,406,870 L $(900,000$ gal) of water will be required at a flow of $757 \mathrm{~L}$ (200 gal) per minute for three separate injection phases. Well 399-1-7 was chosen as the extraction well for the make up water to be used during injection testing. This well is located $188 \mathrm{~m}(617 \mathrm{ft})$ to the southeast of well 399-1-23 (Figure 1.2). A one time drawdown test was conducted in early November to determine if the well yield would be sufficient to achieve the desired flow rate. The test demonstrated that at $340 \mathrm{~L}$ (90 gal) per minute (largest pump available at the time) the well displayed minimal drawdown. It was believed that the well capacity would easily accommodate a flow rate of $757 \mathrm{~L}(200 \mathrm{gal})$ per minute. In late November, a submersible Grundfos Model 230S150-5B stainless steel pump was purchased and installed in the extraction well. A magnetic starter (Cerus, Industrial) is used to operate the pump (15 hp, three phase $460 \mathrm{~V}$ ) and is located in the process trailer.

A tracer injection test was performed in December 2006 at a flow rate 757 L (200 gal) per minute using this equipment. The extraction well was able to yield sufficient water for the desired flow rate and the pressure drop through the entire system was low enough to sustain this rate. During this test, pressure 
buildup in the injection well was approximately $0.06 \mathrm{~m}(0.2 \mathrm{ft})$; no drawdown was observed at the extraction well location. Although there is potential for hydraulic interference between these two aquifer stresses located $188 \mathrm{~m}(617 \mathrm{ft})$ apart, the impact would likely have little or no impact on amendment transport over the duration of injection operations. Analysis of the bromide tracer test results show localscale heterogeneities had a greater impact on the tracer distribution at the site (see Section 6.3). In addition, time-varying impacts to the flow field associated with variability in Columbia River stage would be expected to have a larger impact on amendment transport than any interference between injection/ extraction operations.

\subsubsection{Injection Equipment}

Make-up water is delivered to the injection well via a 7.6-cm (3-in.) lay flat hose. The hose is a Goodyear 4520 hose constructed out of rugged PVC with a pressure rating of $250 \mathrm{psi}$. Aluminum camlock fittings are utilized as connectors for $\sim 213 \mathrm{~m}$ (700 ft) of hose. The hose comes in 15 and $30 \mathrm{~m}$ (50 and $100 \mathrm{ft}$ ) sections. The end of the hose is reduced to $5 \mathrm{~cm}$ (2 in.) camlock fittings and connected to the injection manifold in the process trailer. The injection manifold (Figure 5.2) consists of 5-cm (2-in.) stainless steel piping, valving, a pump, and flow rate monitoring equipment. The manifold is used for diversion/shutoff and flow control of the make up water and for dilution of a concentrated feed stock solutions to the desired injection concentration. The tracer or polyphosphate amendment solutions are fed into the system at the manifold via a chemical metering pump or equivalent. The flow is measured with an inline Omega ${ }^{\circledR}$ turbine flow meter or rotometer. The total of the makeup water and feed solution is measured with a 757 L (200 gal) per minute rotometer (King Instrument Company model 7500) and an inline Omega ${ }^{\circledR}$ turbine flow meter. Both inline flow meters are logged using a Campbell CR10X data logger.

Two pressure gauges are located in the system; at the inlet and outlet of the injection manifold (Figure 6.15). The injection well is outfitted with $15 \mathrm{~m}$ (50 ft) of 7.6- $\mathrm{cm}$ (3-in.) schedule 40 PVC pipe with the bottom section capped. A total of fifteen rows of $0.6-\mathrm{cm}(0.25$-in.) holes (four holes per row) were drilled into the PVC which corresponds to approximately one half the open area of the 7.6- $\mathrm{cm}$

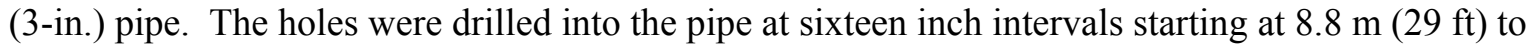
$14.9 \mathrm{~m}(49 \mathrm{ft})$ below ground surface.

\subsubsection{Monitoring Equipment}

Dedicated "Mega Typhoon" sampling pumps (Proactive Pumps, Trenton NJ), capable of delivering flows up to $7.57 \mathrm{~L}$ ( 2 gal) per minute, were installed in all site monitoring wells. The sample tubing ( $0.95 \mathrm{~cm}$ [0.375 in.] polyethylene) from each of these sampling pumps is routed inside a mobile laboratory and connected to a sampling manifold. A single DC power supply (model 1688A) from $\mathrm{B}+\mathrm{K}$ Precision Corp. (Yorba Linda, CA) provides power for the sampling pumps. The power to the sampling pumps is regulated by a manufacturer recommended pump controller which increases the operating voltage of the pumps to 19 volts (and subsequently a lower current demand). A project-developed multichannel interface (pump switch box) is used to allow a single power supply/controller arrangement to provide power to all 10 sampling pumps. A multi-position rotary switch on the switch box eliminates the possibility of powering more than one pump at a time. 


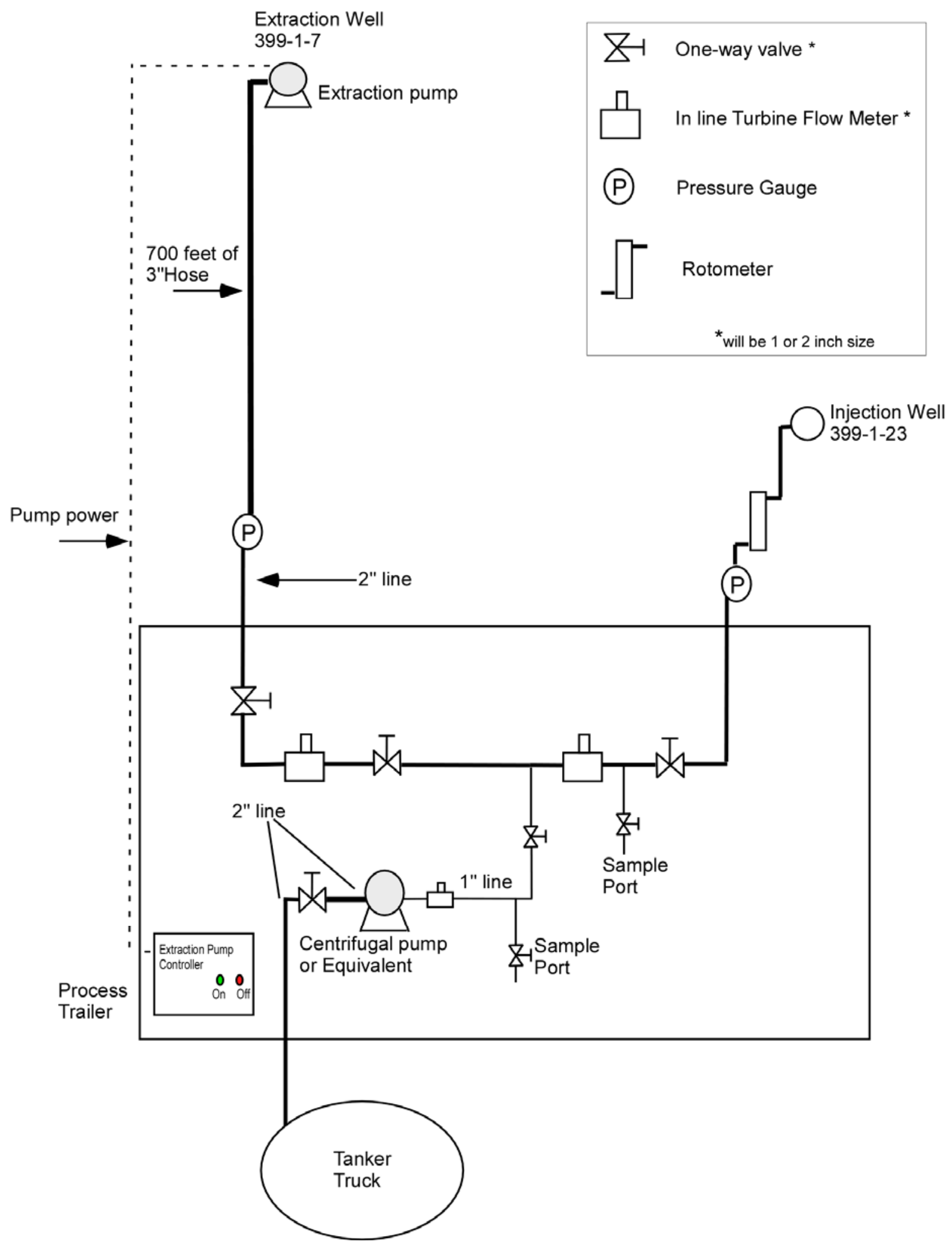

Figure 5.2. Schematic of the Injection Manifold with the Make-Up Water and all Other Necessary Components 
A project-developed sampling manifold is used to collect samples from the various monitoring wells. This approach routes all sample streams into a central manifold for monitoring field parameters (in a flow-through monitoring assembly) and collecting groundwater samples (Figure 5.3). The advantage of this type of system is that all field parameter measurements are made using a single set of electrodes, which improves data quality and comparability of spatially distributed measurements. Consistent labeling between the sampling manifold and pump switch box simplifies selection of the well to be sampled and reduces the chance of operator error during the frequent sampling associated with the injection tests. To further help reduce the potential for collecting sample from the wrong well, the pump switch box is wired to a series of light-emitting diode (LED) lights on the sample manifold. When a pump is turned on, a light comes on to indicate which pump is operating, and which valve on the manifold should be opened.

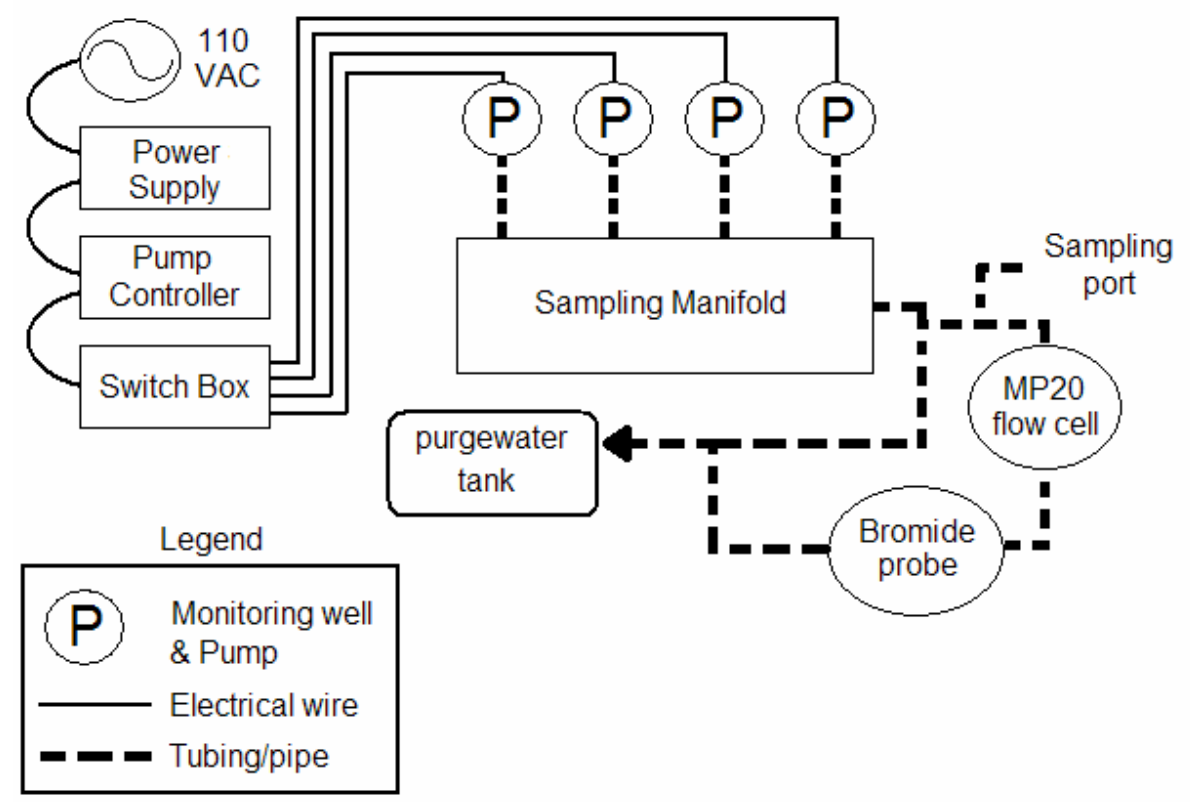

Figure 5.3. Schematic Drawing of the Groundwater Sample Acquisition System

Field parameters (specific conductance, temperature, dissolved oxygen, $\mathrm{pH}$ and oxidation reduction potential) are monitored using an MP20 flow cell (QED Environmental Systems, Ann Arbor MI). The flow-through nature of the flow cell assembly minimizes the amount of dead space within the monitoring chamber.

To track the injection, ion selective probes may be installed in the injection and monitoring wells. It must be determined if bromide or chloride can be used in the polyphosphate solution without affecting the solution chemistry. An infrastructure is already in place for bromide monitoring. During the tracer test in December, a bromide ion selective electrode (ISE) probe (TempHion, Instrumentation Northwest Inc.) was plumbed in series with the MP20 flow cell, providing real-time estimates of bromide concentration in the field. This bromide probe was housed in a separate flow-through chamber. Prior to sampling, it was determined that the housing for the bromide probe required a 3.78-L (1-gal) purge volume for readings to stabilize. This bromide set up will remain in place and may be used during the next injection if it is determined that bromide can be mixed with the polyphosphate solution and used as a conservative tracer and that the polyphosphate amendments do not interfere with the ISE readings. In addition to bromide, chloride associated with the second phase of the polyphosphate treatment $(\mathrm{CaCl}$ injection, see discussion 
in Section 2) may also be monitored using a TempHion probe. The probes will be attached to a Campbell Scientific (Logan, UT) CR10X data logger programmed to record data at a frequency ranging from 5 to 30 minutes.

Pump rates from the wells are maintained at $3.78 \mathrm{~L}(1 \mathrm{gal})$ per minute to minimize drawdown in the monitoring wells and, based on volumetric calculations, it was determined that a 2-minute purge time would be prescribed to assure adequate purging of the sample lines, manifold, flow cell and bromide probe housing. During the tracer injection test, flow cell readings generally stabilized in less than a minute, indicating that the 2-minute purge time was adequate. The sensors used to measure field parameters during this test meet the specifications shown in Table 5.1.

Table 5.1. Field Parameter Monitoring Electrode Specifications

\begin{tabular}{||l|c|c|c||}
\hline \multicolumn{1}{|c|}{ Parameter } & Manufacturer/Model \# & Range & Accuracy \\
\hline \hline $\mathrm{pH}$ & QED/MP20 & 2 to $12 \mathrm{pH}$ units & $\pm 0.2 \mathrm{pH}$ \\
\hline $\begin{array}{l}\text { Oxidation Reduction } \\
\text { Potential }\end{array}$ & QED/MP20 & -999 to $999 \mathrm{mV}$ & $\pm 25 \mathrm{mV}$ \\
\hline Temperature & QED/MP20 & 5 to $50^{\circ} \mathrm{C}$ & $\pm 0.2^{\circ} \mathrm{C}$ \\
\hline Specific Conductance & QED/MP20 & 0 to $100 \mathrm{mS} / \mathrm{cm}$ & $\pm 1 \%$ \\
\hline Dissolved Oxygen & QED/MP20 & 0 to $50 \mathrm{mg} / \mathrm{L}$ & $\pm 0.2 \mathrm{mg} / \mathrm{L}$ \\
\hline Bromide or Chloride & Instrumentation NW TempHion & Calibrate to specified range & $\pm 5 \%$ of range \\
\hline
\end{tabular}

\subsubsection{Analytical Measurements}

Prior to the polyphosphate injection test, three rounds of baseline samples will be collected and analyzed for a variety of metals, cations and anions. The analytes and sample handling specifics are outlined in Section 7. Samples will be collected in 20-mL plastic bottles. Similar to the baseline sampling, samples collected during the injection/withdrawal activities, will be collected in 20 -mL plastic bottles. For all samples collected, field parameters will be measured in the flow through cells. Samples will be selected for analysis based on the results of the field parameter measurements. All analyses were conducted by a PNNL operated analytical laboratory according to PNNL developed procedures (PNL-MA-567; PNNL 1994).

\subsubsection{Water-Level/Pressure Response Measurement}

A network of submersible pressure sensors have been in place since December 2006 to monitor pretest background water levels, pressure responses during the test, and post-test background water levels. Sensors were installed in the source well (399-1-7), the injection well (399-1-23) and each of the nine monitoring wells (Figure 5.4). The pressure sensors are digitally networked using cables for the 10 proximal wells and radio transceivers for the distant water-source well (Figure 6.17). The radios consist of a pair of Instrumentation Northwest (INW, Kirkland, WA) WaveData short-haul radio frequency modems. The sensor network terminates in a single-drop access point to the field computer located inside the sample trailer.

Integrated datalogger pressure sensors (INW model PT2X) with a $0-15$ psig range and $0.1 \%$ full-scale accuracy will be used. The sensors are vented at the ground surface with vented cables to allow for compensation with barometric pressure changes. Pressure response measurements will be continuously recorded to an internal memory logger on each sensor and periodically downloaded to a field computer 
through the single-point connection in the sensor network. In addition to the continuous internal data logging, pressure measurements will also be recorded to a separate data file located on a field computer during the injection phase of the test in order to ensure data redundancy and backup. This is made possible by having all 11 sensors serially networked to a field computer running INW's Aqua4Push software. The software automatically polls each sensor in the digital network at a user-defined interval and appends these values to a single data file. This is similar to traditional analog systems (e.g., Campbell Scientific, Inc. data logger) except for the ability to simultaneously log data to two separate recording systems rather than a single one.

Water levels will be measured using a high-accuracy, National Institute of Standards and Technology traceable, non-stretch, metal-taped, water-level-meter marked in 0.003-m (0.01-ft) gradations. The northside of the top of casing will be used as the vertical reference point for all water levels.

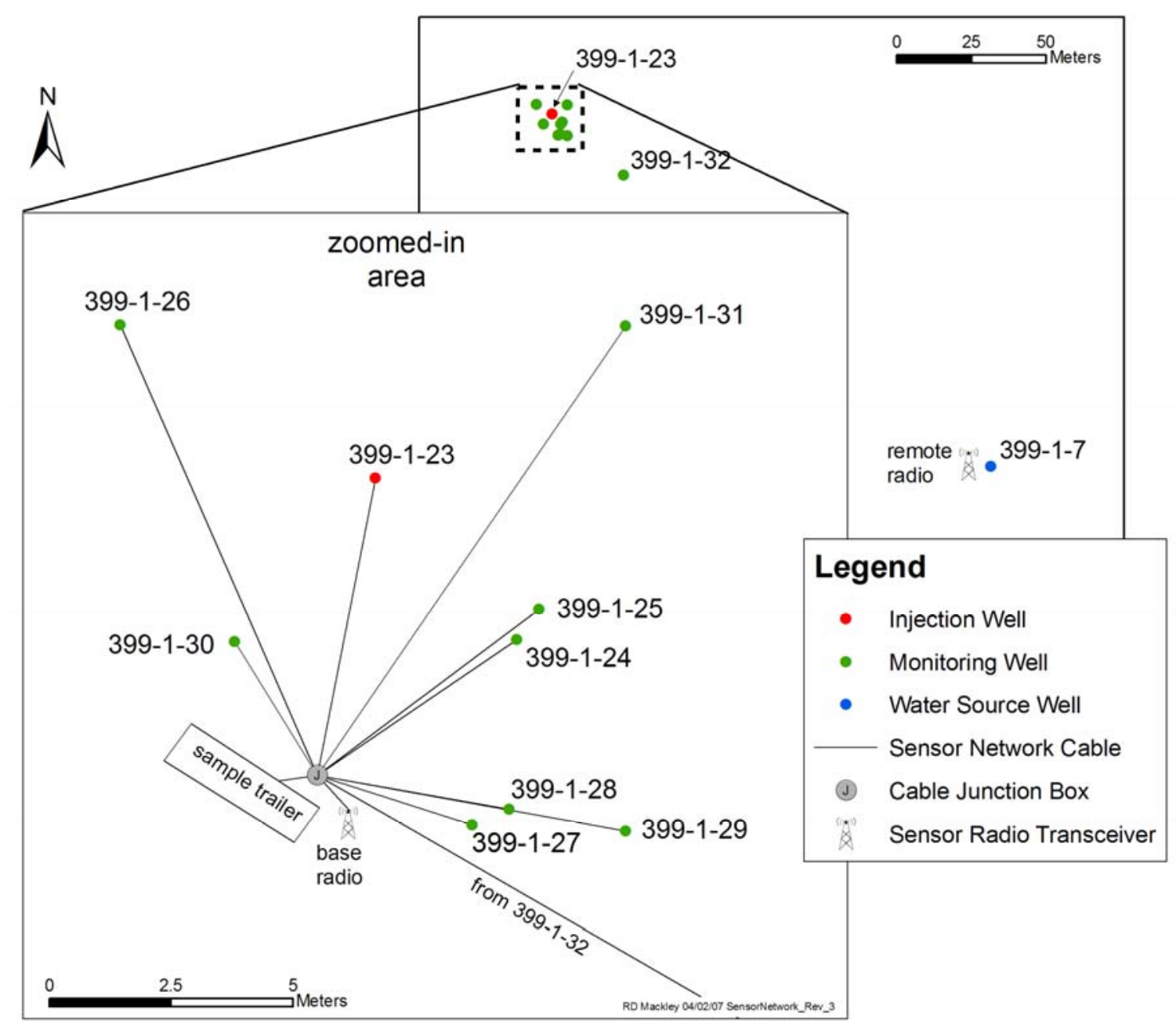

Figure 5.4. Schematic Layout of Pressure Sensor Network 


\subsection{Field Testing Activities}

As discussed in Section 1, the polyphosphate treatability test site was selected from one of the four locations characterized during the 300 Area LFI drilling (Williams et al. 2007) around well 399-1-23 (see Figures 1.2 and 1.3). Well 399-1-23 will be used as the injection well for the treatability test. Monitoring wells were installed around the injection well in November and December 2006 (see Figure 6.1) and are described in Williams (2007) and summarized below. Additional monitoring wells will be installed at the site in the spring of 2007. The following sections describe results of site characterization activities conducted to date and provide a detailed discussion of the polyphosphate treatability test injection design and associated chemical requirements for field-scale treatment.

\subsection{Well Installation and Geohydrologic Characterization}

Nine new groundwater monitoring wells (Table 6.1) were installed between November and December 2006. The relative location of these wells is shown on the location map in Figure 6.1 (downgradient well 399-1-32 shown on Figure 1.3). In addition to these nine well locations, six more downgradient monitoring wells will be installed at the treatability test site in April/May 2007 (Figure 6.2) to support monitoring of the polyphosphate injection test during high river stage conditions. The rational behind orientation of these new downgradient well locations is discussed in Section 6.2.

The new wells were constructed to the specifications and requirements described in Washington Administrative Code (WAC) 173-160, the Site Characterization Plan: Uranium Stabilization through Polyphosphate Injection (Vermeul et al. 2006), and specifications provided by Fluor Hanford, Inc., Richland, Washington. During drilling and construction of the wells, sampling and analysis activities were conducted to support field screening for radiological and chemical contaminants and to collect near continuous sediment samples for geologic description. The borehole logs for these nine new wells were evaluated to determine the stratigraphic contacts and key lithologic changes where possible, as reported in Williams (2007). These results were compared to borehole investigation results from well 399-1-23 contained in Williams et al. (2007).

The uppermost unconfined aquifer beneath the polyphosphate treatability test site consists of unconsolidated gravel-dominated sediments of the Hanford fm. unit 1. The Hanford - Ringold contact boundary ranged in depth between approximately 13.1 and $15.2 \mathrm{~m} \mathrm{(43} \mathrm{and} 50 \mathrm{ft}$ ) bgs in the new boreholes

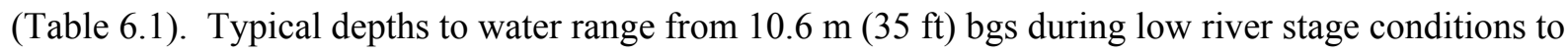

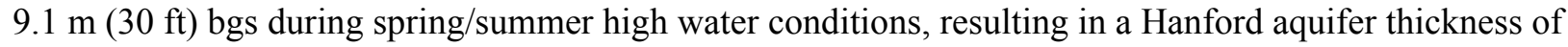

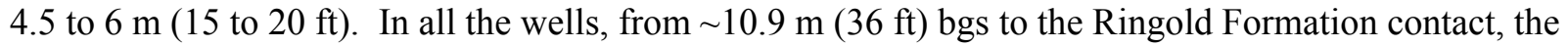
Hanford formation consists predominantly of coarse sandy gravel to gravel. A more open framework, i.e., clast supported structure; composed of predominantly gravel to slightly sandy gravel is reported in wells 399-1-24, 399-1-26, 399-1-30, and 399-1-31 in the lower Hanford fm. from approximately $10.9 \mathrm{~m}$ (36 ft) bgs down to the Hanford - Ringold contact; where present, the matrix sand is composed of medium to coarse sand.

The Ringold Formation unit 5 that lies beneath the Hanford formation is composed of mostly gravelly silty sand to sand. With the exception of two shallow well pairs and the earlier LFI well 399-1-23 (which was drilled down to the lower mud unit), the wells were drilled a few feet into the Ringold Formation to a total depth of $\sim 15.5 \mathrm{~m}(51 \mathrm{ft}) \mathrm{bgs}$ (Table 6.1$)$; therefore, only the upper few feet of Ringold Formation 


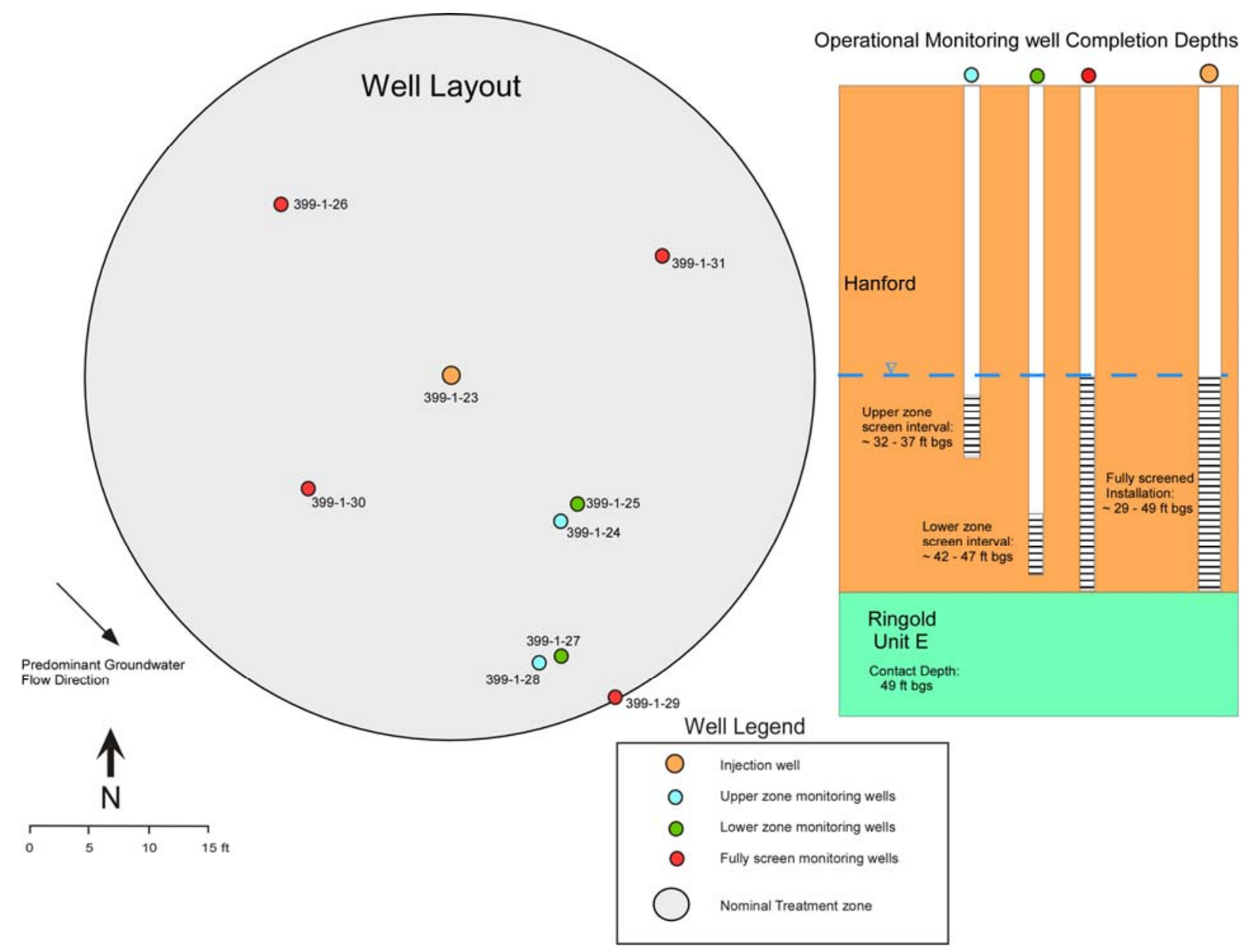

Figure 6.1. Initial Well Layout for Polyphosphate Treatability Test Site Showing Well Construction

Table 6.1. Polyphosphate Treatability Well Identification and Borehole Information

\begin{tabular}{|c|c|c|c|c|c|c|c|c|}
\hline Well Name & Well ID & $\begin{array}{l}\text { Surface } \\
\text { Elevation } \\
\text { (ft) }\end{array}$ & $\begin{array}{l}\text { Total Drill } \\
\text { Depth } \\
\text { (ft bgs) }\end{array}$ & $\begin{array}{c}\text { DTW } \\
(\mathrm{ft} \text { bgs) }\end{array}$ & $\begin{array}{c}\mathrm{H} / \mathrm{R} \\
\text { Contact } \\
\text { (ft bgs) }\end{array}$ & $\begin{array}{l}\text { Saturated } \\
\text { Hanford } \\
\text { fm. }(\mathrm{ft})\end{array}$ & $\begin{array}{c}\text { Elevation } \\
\mathrm{H} / \mathrm{R}(\mathrm{ft})\end{array}$ & $\begin{array}{c}\text { Screen } \\
\text { Interval/Length } \\
\text { (ft bgs [and } \mathrm{ft}] \text { ) }\end{array}$ \\
\hline $399-1-23^{(\mathrm{a})}$ & C5000 & 378.84 & 116 & 34.5 & 251 & 16.5 & 327.84 & $25-50(25 \mathrm{ft})$ \\
\hline $399-1-24$ & C5351 & 379.35 & 42 & 33.8 & NDE & NDE & NDE & $32-37(5 \mathrm{ft})$ \\
\hline $399-1-25$ & C5352 & 379.27 & 50 & 34.3 & 48.2 & 13.9 & 331.07 & $42-47(5 \mathrm{ft})$ \\
\hline $399-1-26$ & C5353 & 378.82 & 50.5 & 33.8 & 48.5 & 14.7 & 330.32 & $29-49(20 \mathrm{ft})$ \\
\hline $399-1-27$ & C5354 & 379.59 & 50 & 34.9 & 48 & 13.1 & 331.60 & $42-47(5 \mathrm{ft})$ \\
\hline $399-1-28$ & $\mathrm{C} 5355$ & 379.64 & 40.5 & 34 & NDE & NDE & NDE & $32-37(5 \mathrm{ft})$ \\
\hline $399-1-29$ & C5356 & 379.60 & 51 & 35 & 49 & 14 & 330.60 & $29-49(20 \mathrm{ft})$ \\
\hline $399-1-30$ & $\mathrm{C} 5357$ & 379.38 & 50.5 & 33.6 & 49.75 & 14.75 & 329.63 & $29-49(20 \mathrm{ft})$ \\
\hline $399-1-31$ & C5358 & 379.03 & 51 & 33.7 & 48.5 & 14.8 & 330.53 & $29-49(20 \mathrm{ft})$ \\
\hline $399-1-32$ & C5359 & 378.21 & 50.5 & 32.5 & 43 & 10.5 & 335.21 & $29-44(15 \mathrm{ft})$ \\
\hline \multicolumn{9}{|c|}{$\begin{array}{l}\text { (a) Pre-existing 6-inch-diameter injection well, all other wells are new and } 4 \text { inches in diameter. All screens completed with } \\
20 \text { slot wire-wrap stainless steel and 10-20 mesh silica sand pack. } \\
\text { bgs }=\text { Below ground surface } \\
\text { DTW }=\text { Depth to water. } \\
\text { H/R }=\text { Hanford - Ringold contact boundary. } \\
\text { NDE }=\text { Not deep enough. }\end{array}$} \\
\hline
\end{tabular}




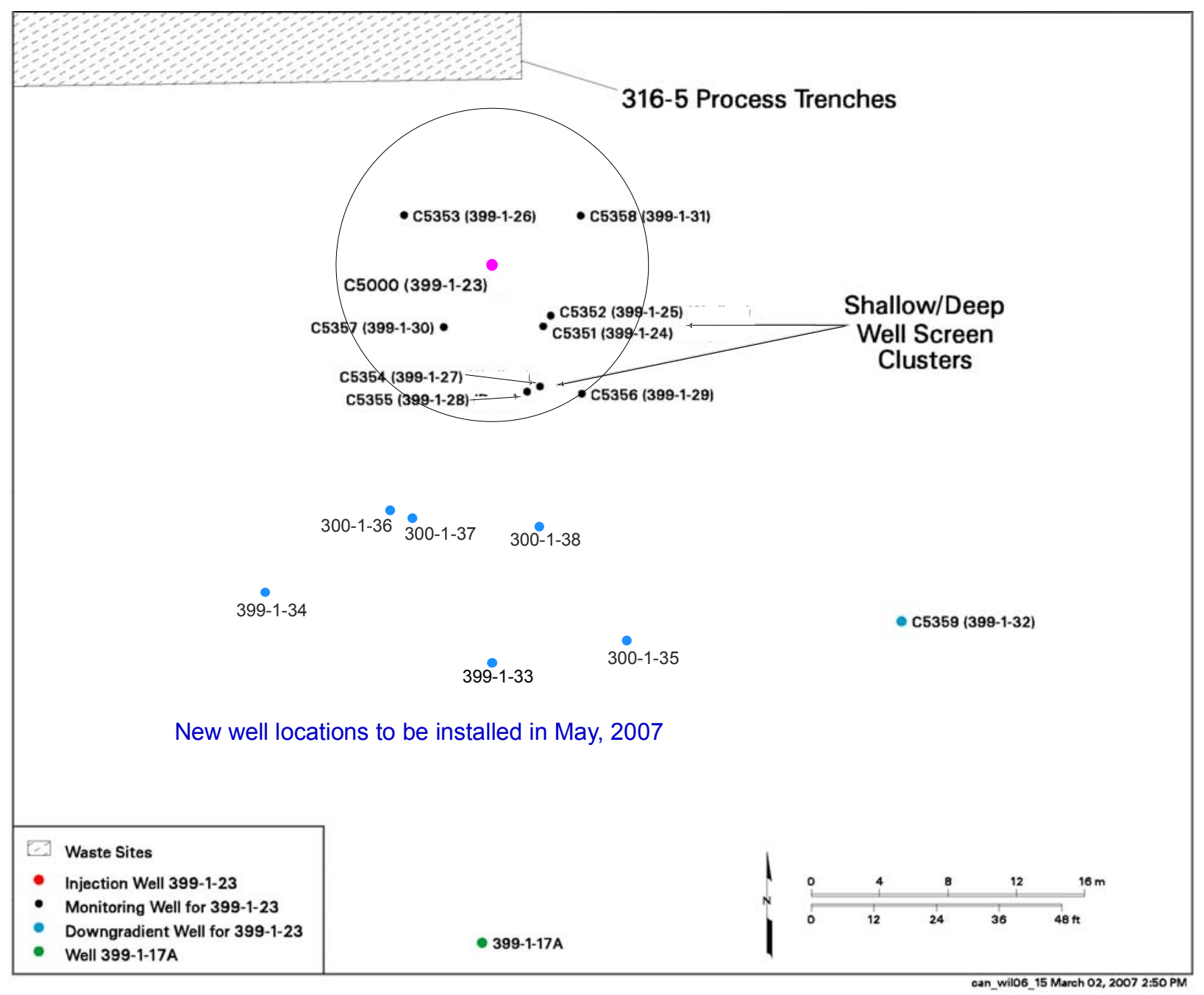

Figure 6.2. Well Layout of Additional Downgradient Monitoring Wells at Polyphosphate Treatability Test Site

sediments were encountered. At all locations, the Hanford - Ringold contact was distinguished by a distinct color change, decrease in gravel size and content, and a significant increase in fine sand. The eastern most well, 399-1-32, encountered the Hanford - Ringold contact 1.2 to $1.5 \mathrm{~m}$ ( 4 to $5 \mathrm{ft}$ ) higher in elevation than in the other new wells (Table 6.1). Approximately $2.3 \mathrm{~m}(7.5 \mathrm{ft})$ of fairly uniform, Ringold Formation sand with only minor amounts of gravel was recovered from the core barrel below the contact. The contact appears fairly well defined in this well and strongly suggests that the Ringold Formation sand encountered in the other wells reflect the same unit.

A cross section showing the hydrogeology through the treatability test site toward the southeast (see Figure 6.3 for transect location) is shown in Figure 6.4. A structural contour map, which was developed during 2006 based on the LFI wells and re-analysis of existing well logs and geophysical logs around the 300 Area, is shown in Figure 6.5. These figures show that the Hanford formation becomes thinner from the test site toward the east at a structural high in the Ringold Formation around well 399-1-7. The Hanford formation becomes thicker again on the eastern side of this feature towards the Columbia River. 


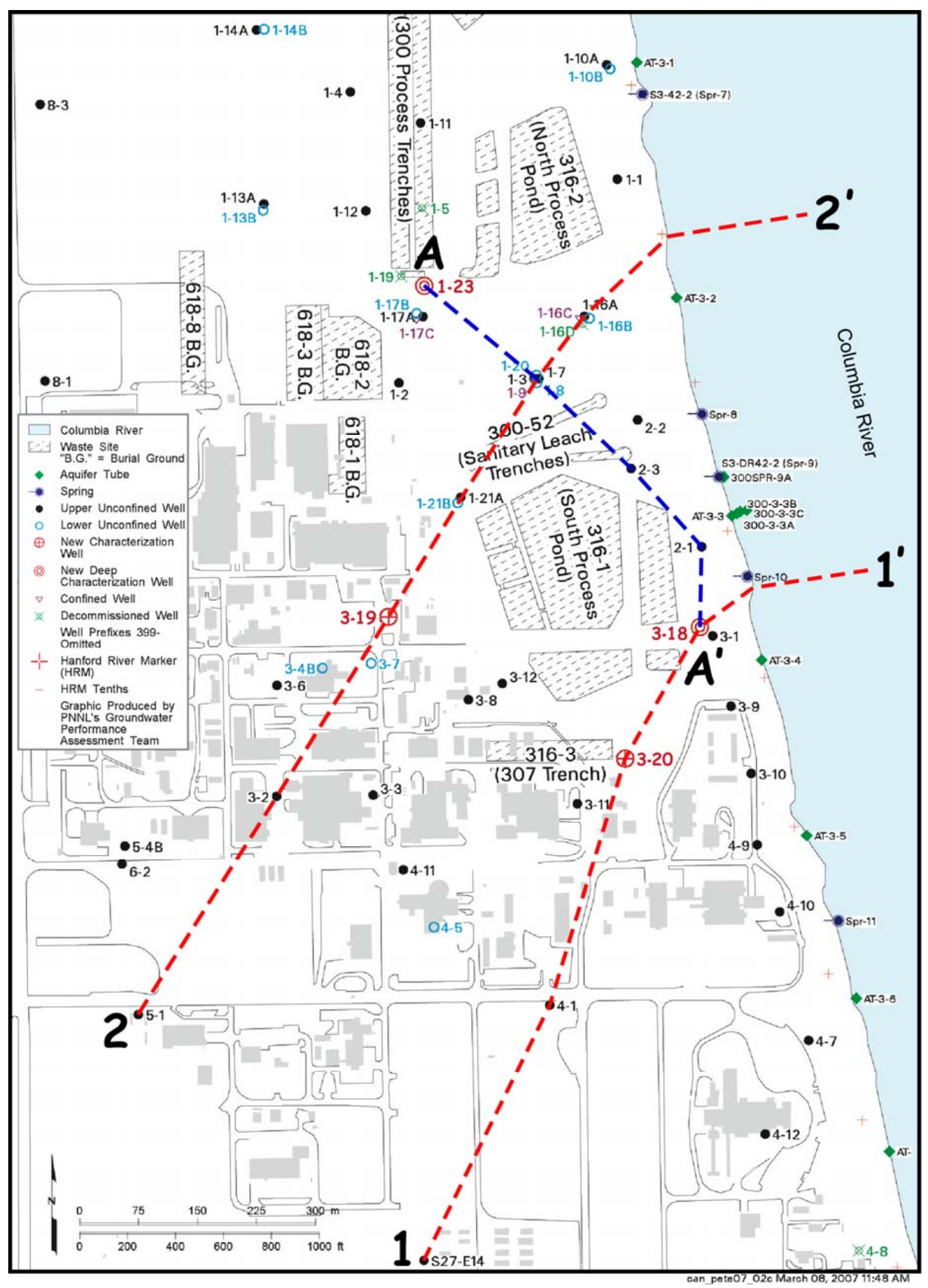

Figure 6.3. Map Showing Transect Location for Figure 6.4 (A-A') 


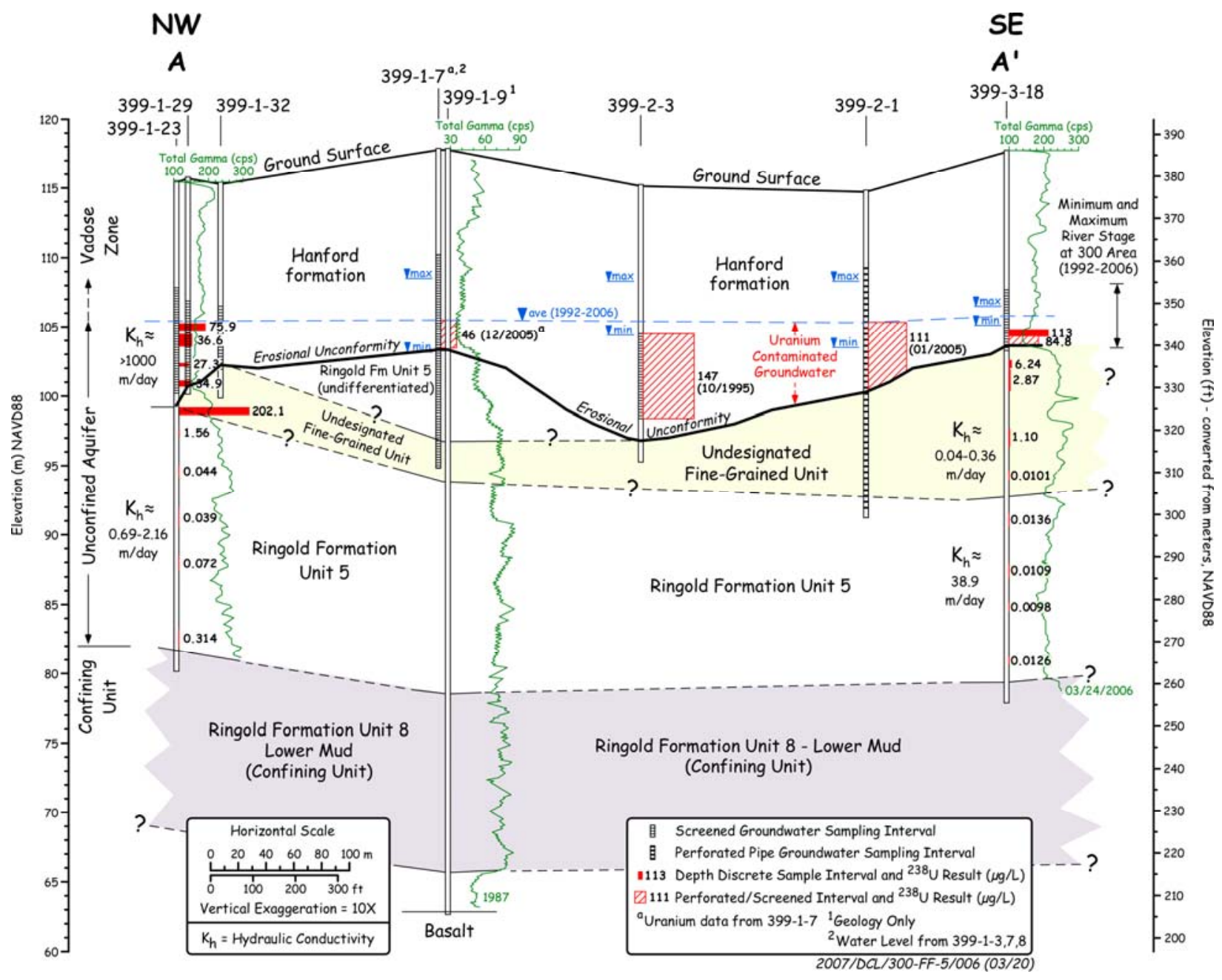

Figure 6.4. Hydrogeologic Cross Section A-A’ (see Figure 6.3 for Transect Location) 


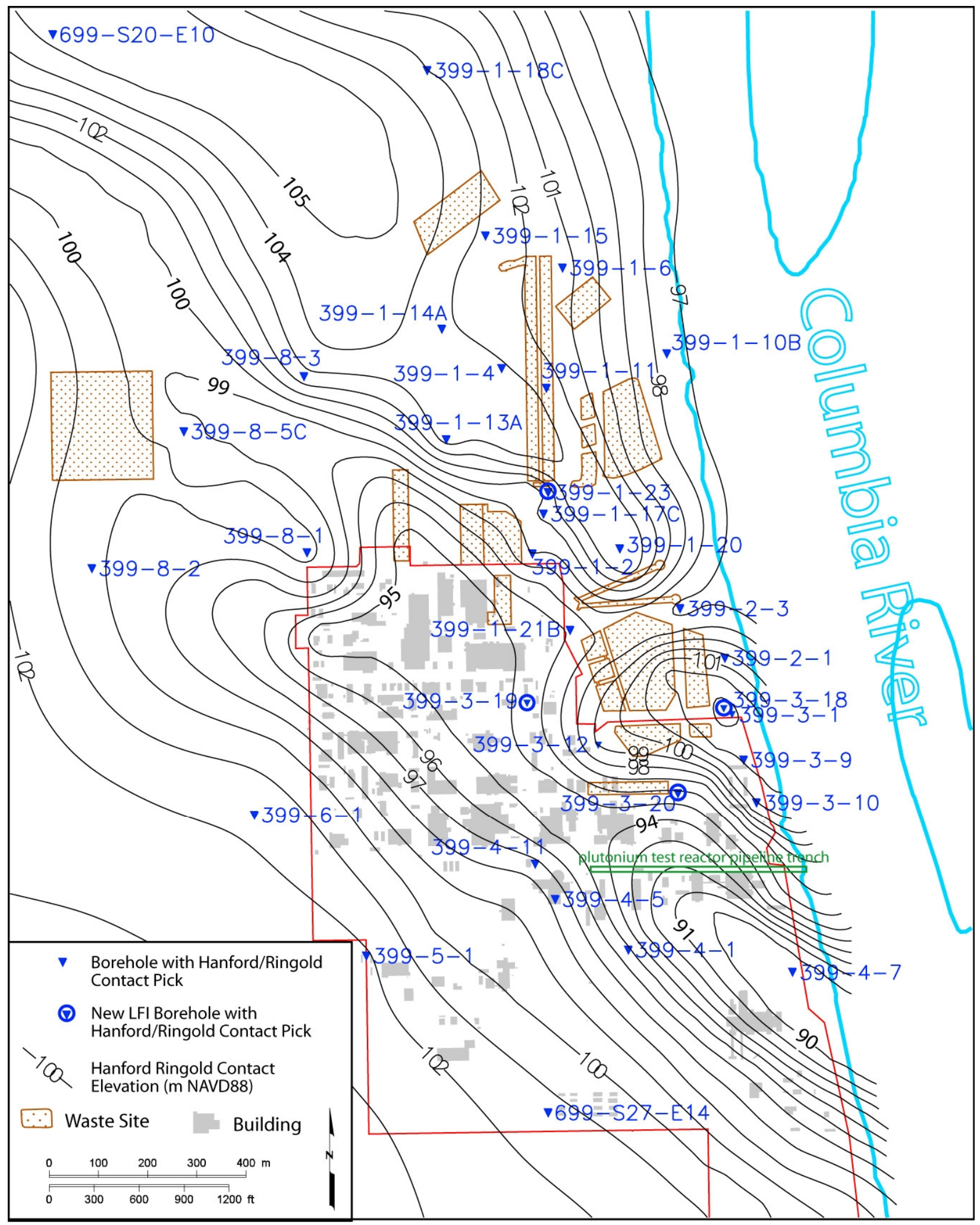

Figure 6.5. Elevation Contour (relief) Map of the Hanford/Ringold Contact Boundary, 300-FF-5 Operable Unit 
As part of the LFI effort, particle size analysis was performed on depth discrete sediment core samples using (1) bulk sediments including gravels and (2) for size fractions less than $2 \mathrm{~mm}$ were conducted using a combination of sieve and hydrometer methods (Gee and Or 2002) for well 399-1-23. A summary of physical and hydraulic property data for the selected samples for which particle-size distributions were measured on the whole (bulk) sample for this well is presented in Table 6.2. Over 90\% of the sediments from the borehole were dominated by gravel and sand sized particles. Higher silt/clay contents (29.7-31.6\%) were found at a depth between 6.4 and $7.6 \mathrm{~m} \mathrm{(21} \mathrm{and} 25 \mathrm{ft})$ bgs, which is consistent with the high moisture contents measured over this depth zone.

Depth-discrete hydraulic tests were also conducted as part of the LFI effort to provide an assessment of the variation and vertical distribution of hydraulic conductivity with depth within the unconfined aquifer at these specific locations (Williams et al. 2007). Aquifer hydraulic testing was generally planned to coincide with selective depth-discrete water sampling, which could then utilize a common, temporary well-screen installation during the sampling/characterization process. Following collection of the water sample, the temporary casing was pulled back to expose $\sim 1.5 \mathrm{~m}(5 \mathrm{ft})$ of screen, and the packer that was attached to the top of the well-screen assembly was then inflated to isolate the test interval. The aquifer hydraulic tests were initiated mechanically by rapidly removing a slugging rod of known volume from the well-screen section. A detailed discussion of these tests, along with the analysis methods and results, are included in Williams et al. (2007).

As indicated in Figure 6.4, hydraulic conductivity estimates for the Ringold Formation ranged from 0.69 to $2.16 \mathrm{~m}$ ( 2.26 to $7 \mathrm{ft}$ ) per day, while estimates for the Hanford formation were reported as being

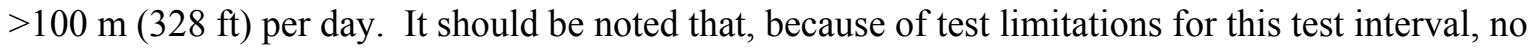
quantitative test analysis was possible; however, the observed test response indicates a high permeability condition. The actual hydraulic conductivity value for this test interval, therefore, is likely to be significantly higher than this assigned minimum value, as confirmed by the hydraulic testing conducted to support this treatability study (see discussion in Sections 6.3 and 6.4). These hydraulic testing results, which are representative of baseline (i.e., pre-polyphosphate injection) conditions, will be compared to post-injection values to assess whether any aquifer plugging occurred during treatment.

\subsection{Water Table and Groundwater Flow Directions}

The water table at the 300 Area is very dynamic due to fluctuations in the Columbia River stage (see Figure 6.6) and the very high permeability of the Hanford formation sediments comprising the uppermost part of the unconfined aquifer. Large daily, weekly, and seasonal fluctuations in the Columbia River stage are caused by the operation of hydroelectric dams on the river and seasonal trends (i.e., spring freshet). The dynamics of river stage fluctuations and the water table elevation cause a mixing zone of river and groundwater within the aquifer. During relatively high river stage periods river water enters the aquifer. Measurements of specific conductance and temperature in wells in the 300 Area, where the groundwater and river water have a large contrast in values, show that river water can encroach more than $190 \mathrm{~m}$ inland in the aquifer during a high river stage period. During relatively low river stage periods, groundwater discharges to the river, as indicated by specific conductance measurements (and other analytes) in aquifer tubes installed below the river bed and in springs along the shoreline (Patton et al. 2003).

The water table for a high river stage period (June) and low river period (December) are shown in Figures 6.7 and 6.8 , respectively. The water table, along with the uranium concentrations, is distinctly 
different during these periods as shown in the figures. Additionally, the water table is relatively flat in the 300 Area (i.e., very small hydraulic gradients) due to the extremely high permeability of the Hanford formation comprising the uppermost portion of the unconfined aquifer.

Table 6.2. Physical Property Data for Bulk Sediment Samples from Well 399-1-23 (from Williams et al. 2007)

\begin{tabular}{|c|c|c|c|c|c|c|c|c|c|}
\hline \multirow[b]{2}{*}{ Well ID } & \multirow[b]{2}{*}{ Sample } & Elevation & \multirow[b]{2}{*}{ Unit } & \multirow{2}{*}{$\begin{array}{c}\text { Bulk } \\
\text { Density } \\
\left(\mathrm{g} / \mathrm{cm}^{3}\right) \\
\end{array}$} & \multirow{2}{*}{$\begin{array}{c}\text { Total } \\
\text { Porosity }\end{array}$} & \multirow[b]{2}{*}{$\%$ Grav } & \multirow{2}{*}{$\begin{array}{c}\% \\
\text { Sand }\end{array}$} & \multirow{2}{*}{$\begin{array}{c}\% \\
\text { Silt }\end{array}$} & \multirow[b]{2}{*}{$\%$ Clay } \\
\hline & & Mid-pt (m) & & & & & & & \\
\hline $399-1-23$ & C5000-39D & 107.83 & $\mathrm{H}$ & 1.95 & 0.293 & 71.78 & 21.15 & 4.16 & 2.92 \\
\hline $399-1-23$ & C5000-40C & 105.69 & $\mathrm{H}$ & 2.34 & 0.152 & 76.18 & 19.43 & 3.02 & 1.37 \\
\hline $399-1-23$ & C5000-40E & 105.08 & $\mathrm{H}$ & 2.31 & 0.165 & 70.59 & 22.12 & 5.34 & 1.95 \\
\hline $399-1-23$ & C5000-41C & 104.47 & $\mathrm{H}$ & 2.34 & 0.153 & 76.45 & 19.73 & 2.55 & 1.26 \\
\hline $399-1-23$ & C5000-45C & 98.99 & $\mathrm{R}$ & 2.26 & 0.182 & 82.77 & 13.18 & 3.03 & 1.02 \\
\hline
\end{tabular}

(a) Particle density was not measured so an average particle density $=2.76 \mathrm{~g} / \mathrm{cm}^{3}$ (see Williams et al. 2006, Table 3) was used to calculate porosities

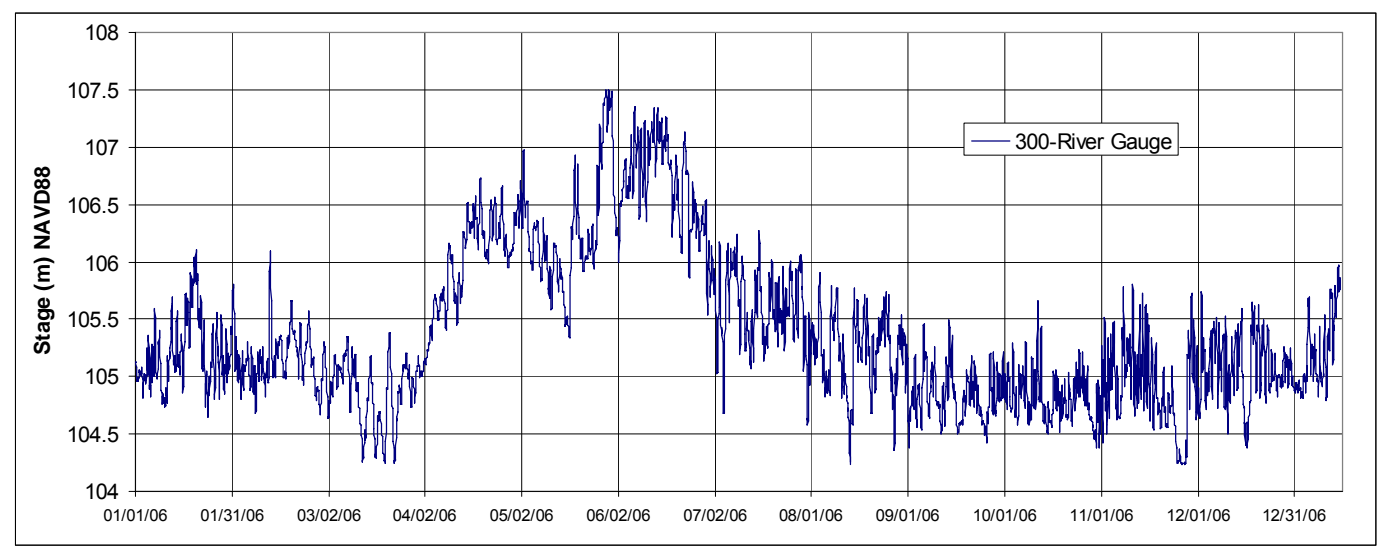

Figure 6.6. Columbia River Stage from the 300-Area Gauging Station for 2006

An automated water-level monitoring network was installed by the Remediation and Closure Science project in the 300 Area in 2004. There were nine wells included initially in this network that collected water levels on hourly and sub-hourly intervals in the area between the North and South Process Ponds and extending westward past the southern portion of the North Process Trenches (see Figure 6.9). Six of these wells also monitored groundwater temperature and electrical conductivity. Contoured hydraulic head data and calculated hydraulic gradients for two selected time periods, high and low river stage for 2006, are shown in Figures 6.9 and 6.10, respectively. As shown by these figures, groundwater flow directions are inland during the June high river period and toward the river during the December low river stage period. Monthly rose diagrams showing the groundwater flow direction from this network using measurements every 2 hours are shown in Figures 6.11 and 6.12.

The 300 Area water-level monitoring network was supplemented in July 2006 with the addition of the polyphosphate injection well (399-1-23) and well 399-1-16A to refine the well coverage from the original network. Two additional wells, 399-1-11 and 399-1-10A, were also added in October 2006 to increase the northern extent of the well coverage (see Figure 6.13). The addition of the polyphosphate injection well to this network shows significant variations in the gradient direction compared to the results from the coarser water level network (compare Figure 6.10 and 6.13). 


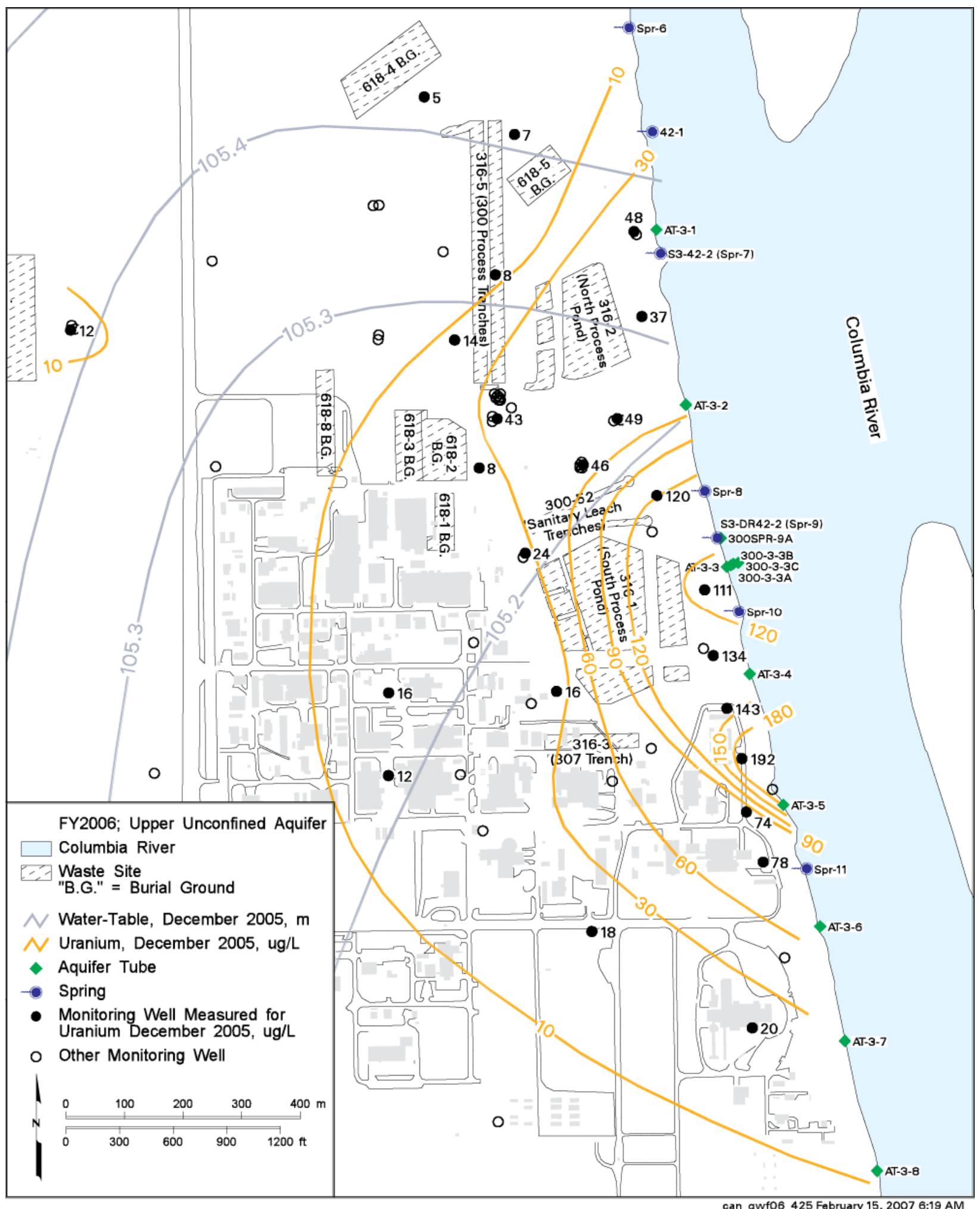

Figure 6.7. Water Table and Uranium Concentrations in Upper Part of Unconfined Aquifer Beneath 300 Area, December 2005 (from Hartman et al. 2007) 


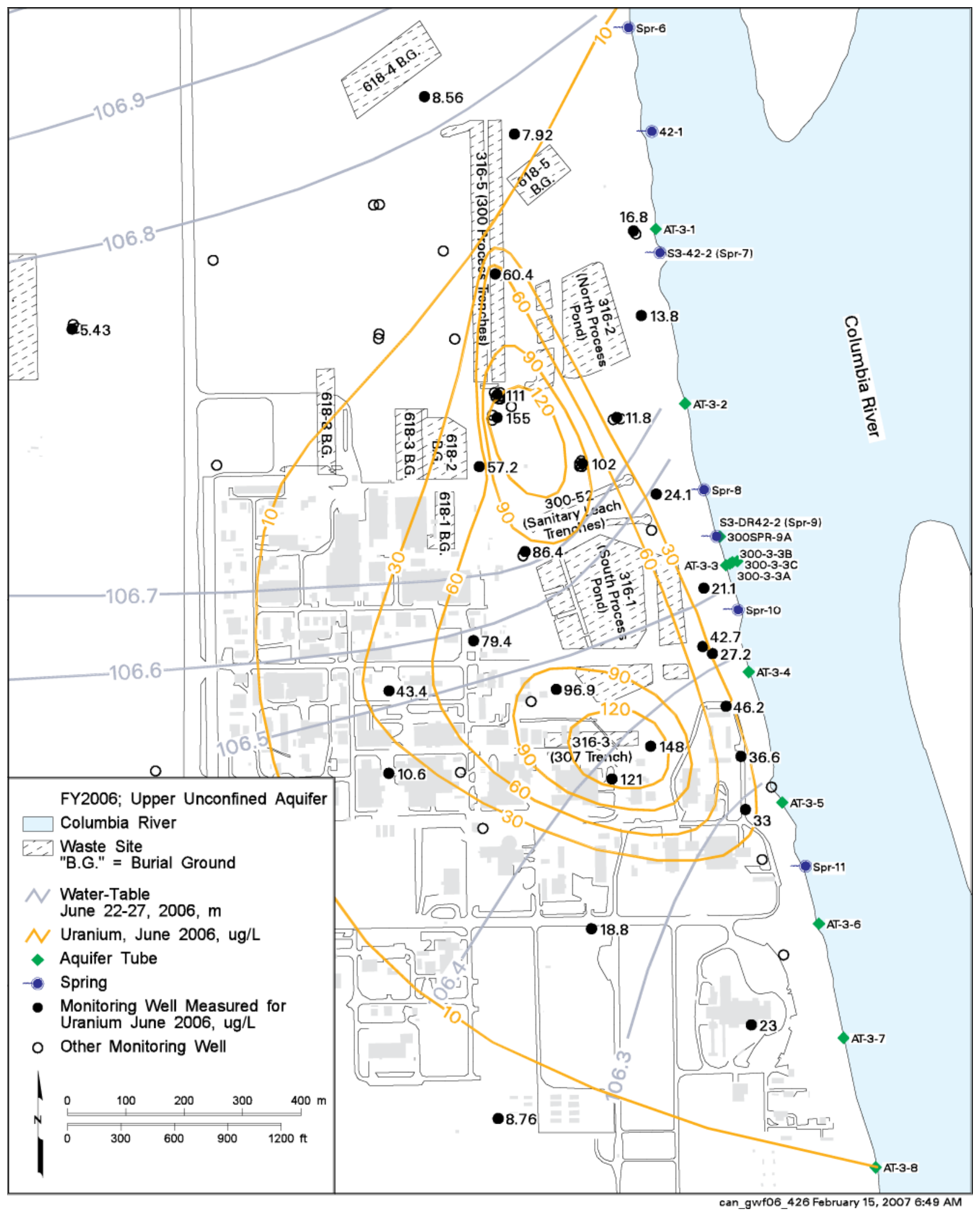

Figure 6.8. Water Table and Uranium Concentrations in Upper Part of Unconfined Aquifer Beneath 300 Area, June 2006 (from Hartman et al. 2007) 


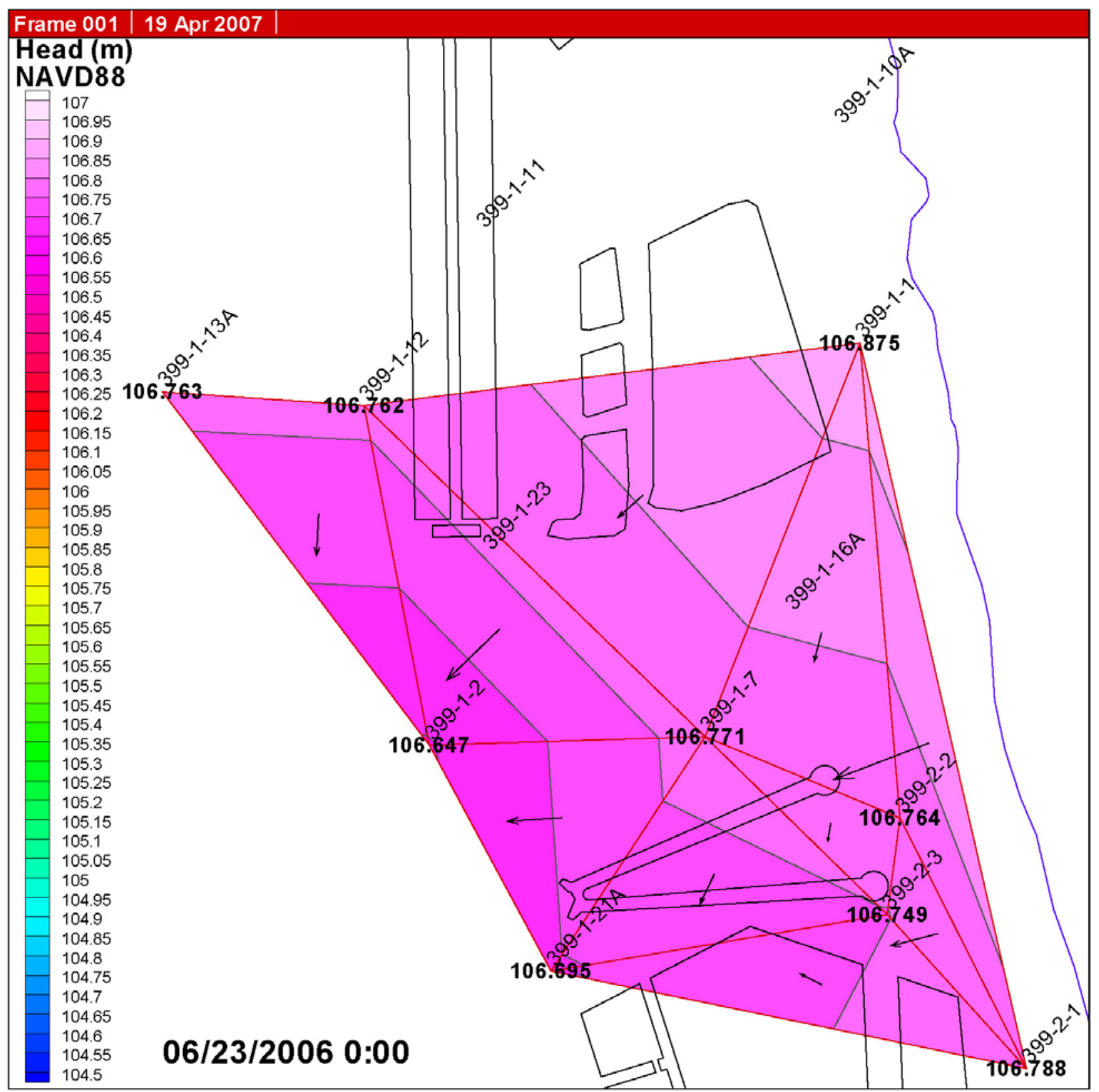

Figure 6.9. Original 300 Area Water-Level Monitoring Network - High River Stage Example 


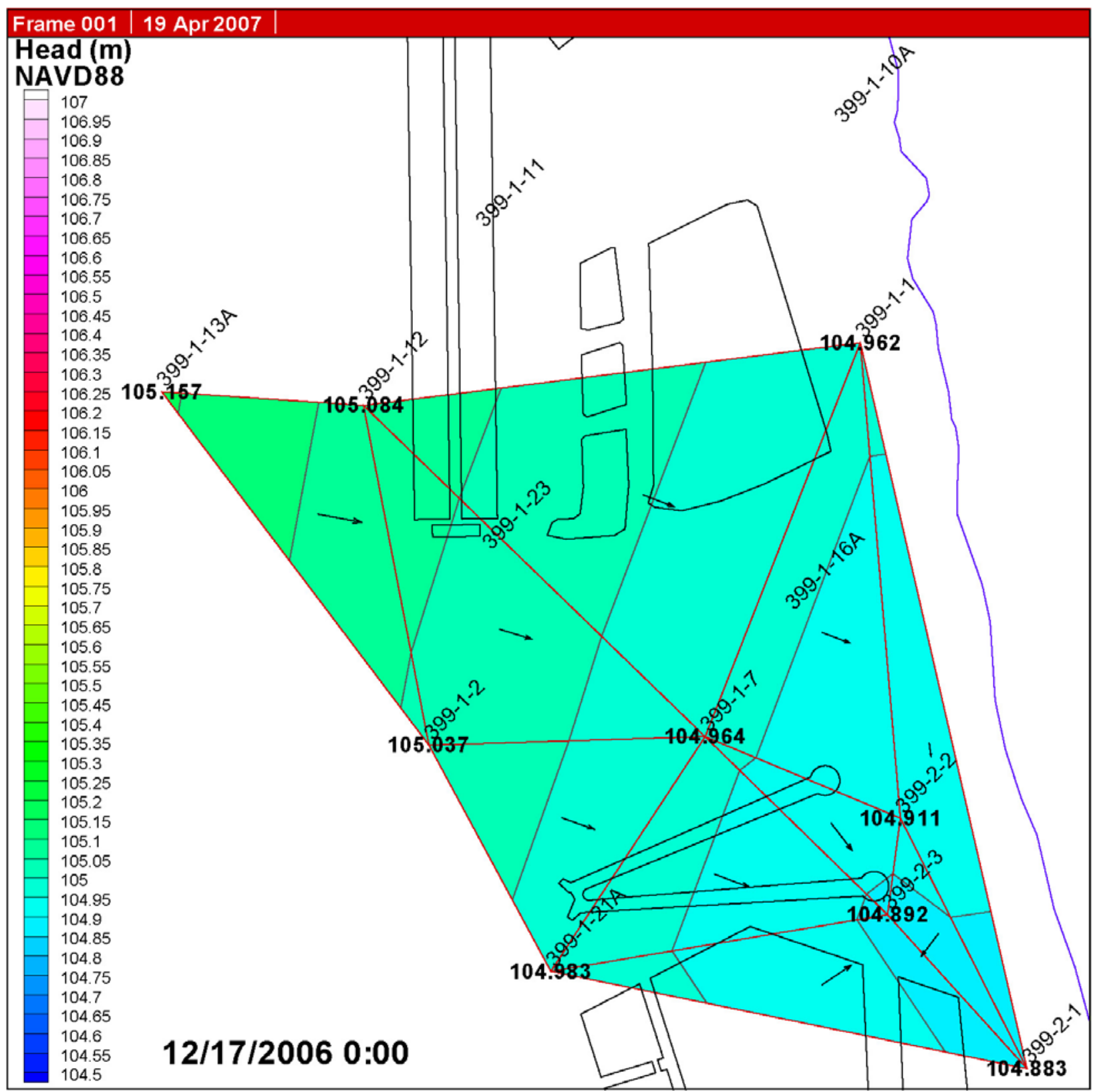

Figure 6.10. Original 300 Area Water-Level Monitoring Network - Low River Stage Example 

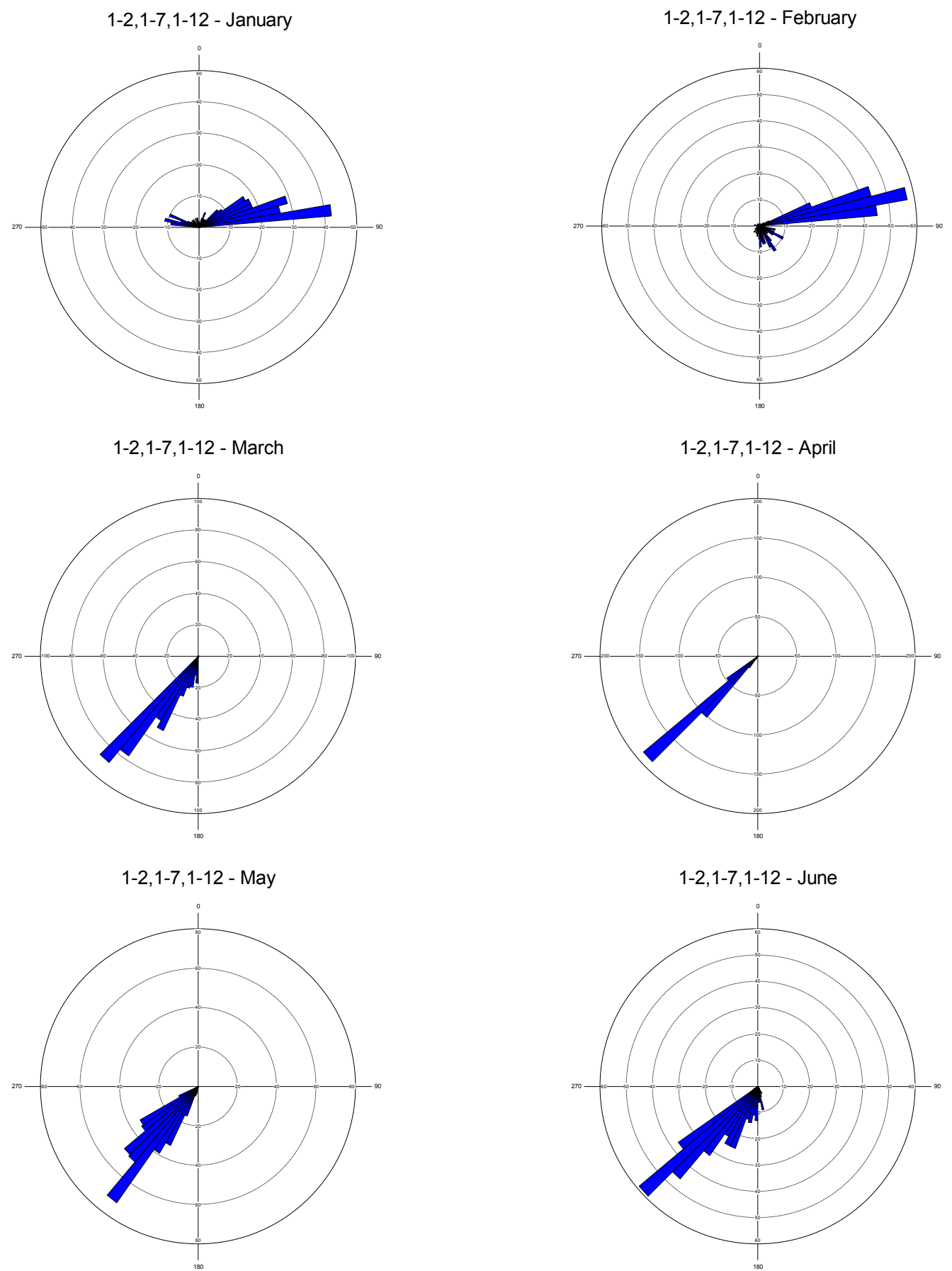

Figure 6.11. Hydraulic Gradient Directions for the First Half of 2006 Calculated from 300 Area Automated Water-Level Network (2-hour data intervals used) for Well Cluster 399-1-2, 399-1-7, and 399-1-12. Azimuth shows direction towards flow (March 16, 2007 data). 

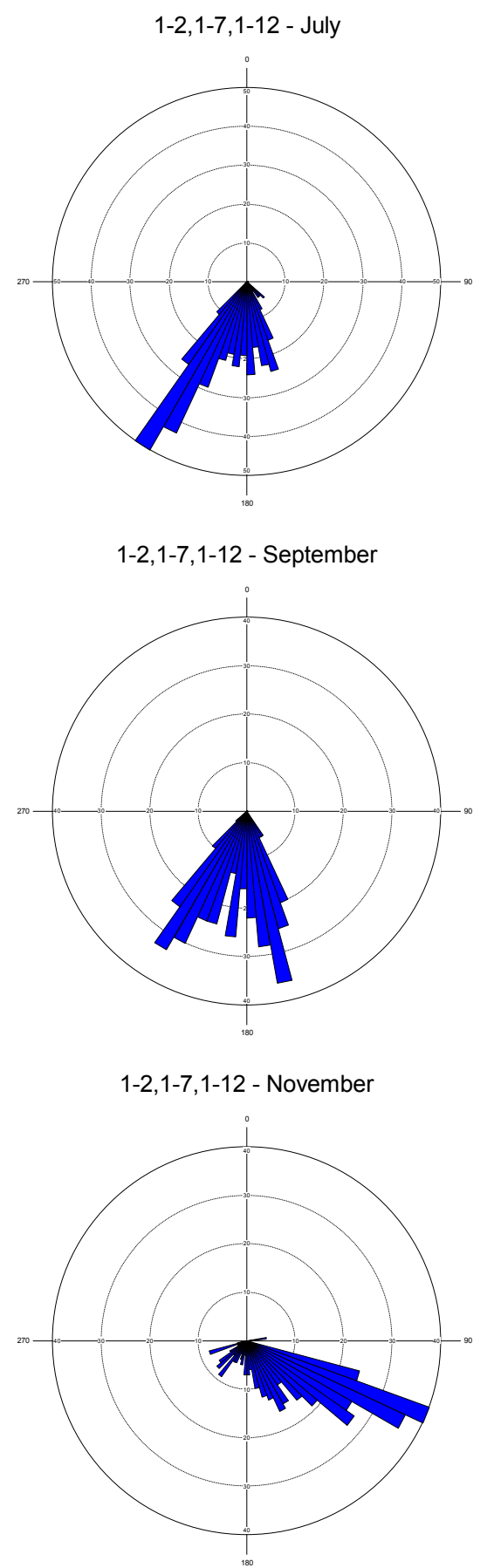

$1-2,1-7,1-12$ - August

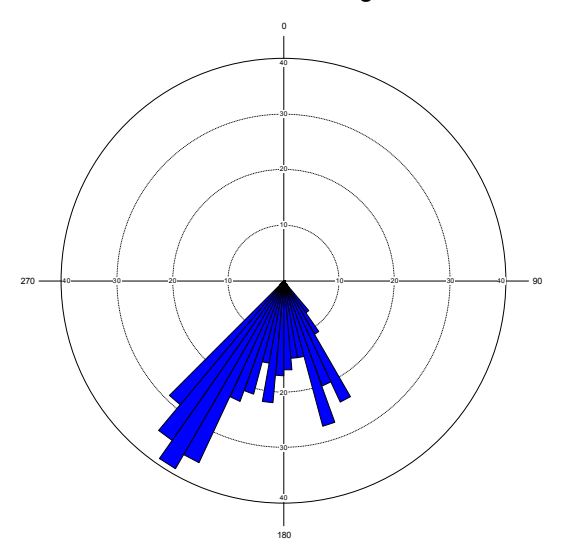

1-2,1-7,1-12 - October

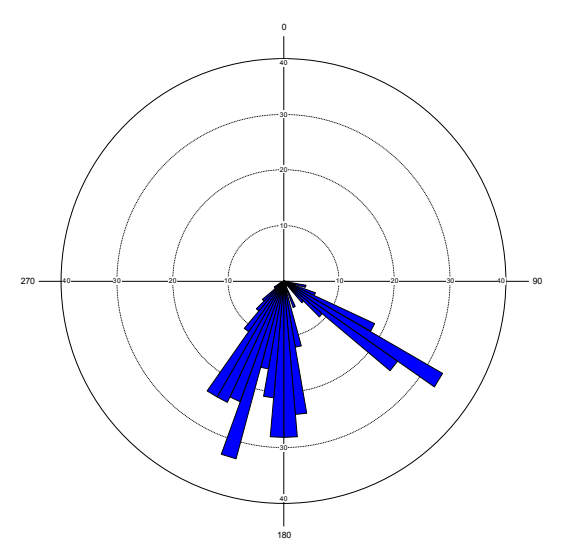

1-2,1-7,1-12 - December

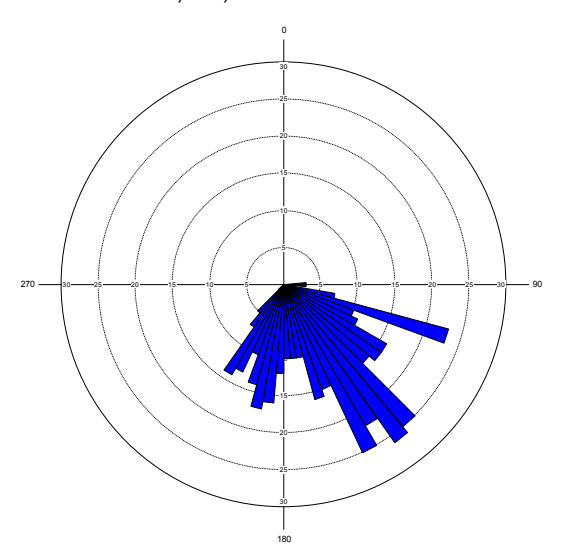

Figure 6.12. Hydraulic Gradient Directions for the Second Half of 2006 Calculated from 300 Area Automated Water-Level Network (2-hour data intervals used) for Well Cluster 399-1-2, 399-1-7, and 399-1-12. Azimuth shows direction towards flow (March 16, 2007 data). 


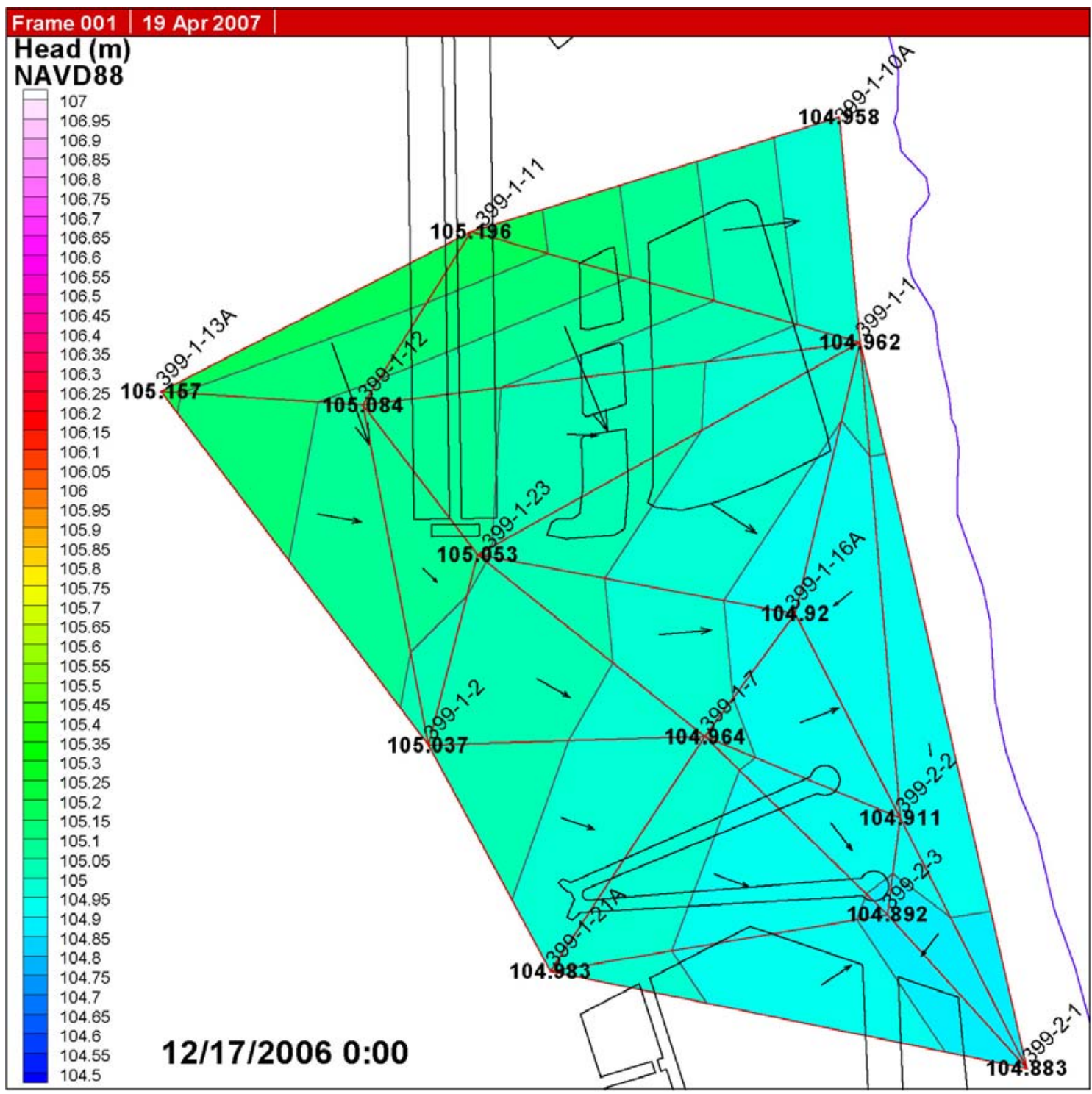

Figure 6.13. Expanded 300 Area Water-Level Monitoring Network - Low River Stage Example

Data from the automated water-level monitoring network were used to select the predominant downgradient direction for the downgradient monitoring well location (399-1-32 in Figure 1.3) for the December 2006 tracer test (predominantly SE from the treatability test site). Results of the tracer test (discussed in Section 6.3) coincided with this direction during that time based on the measured breakthrough curves. An additional set of downgradient wells are being installed at the treatability test site in April/May 2007 (Figure 6.2) and are oriented toward the south-southwest, south, and southsoutheast of the injection well based on the predominant downgradient directions during the high river stage periods (April, May, and June). The higher resolution water level monitoring network that includes the polyphosphate injection well was not operational during a high river stage period, so the coarser dataset was used to guide downgradient directions during this period. The high river stage downgradient orientation was shifted southward from the predominant southwest direction seen in these rose diagrams in consideration of finer-scale water level measurements and to also provide downgradient coverage during later parts of the year (e.g., July through October). 
Groundwater flow velocities are very high in this area given the large hydraulic conductivities. Estimated pore water velocities of $15.2 \mathrm{~m}(50 \mathrm{ft})$ per day were determined from the drift of the December 2006 tracer test (discussed in Section 6.3).

\subsection{Tracer Injection Test}

A tracer injection test was conducted at the polyphosphate treatability test site on December 13, 2006. The objective of the tracer test was to further evaluate formation heterogeneities, to assess the downgradient transport of the tracer plume (i.e., aquifer transport properties), to refine the polyphosphate injection design, and to test operational procedures. Results from the tracer test provide information on the effective porosity of the aquifer, expected arrival times at the monitoring wells, and polyphosphate solution volume required for the targeted treatment zone thickness and radial extent.

\subsubsection{Tracer Test Description}

The tracer test was conducted by injecting a solution containing a conservative, non-reactive bromide (Br) tracer into a central injection well (399-1-23, as shown in Figure 6.1). Bromide concentrations were measured in the injection stream and the surrounding monitoring wells to determine the arrival times and extent of the tracer plume. Table 6.3 summarizes the operational parameters for the tracer test. The concentrated bromide solution was prepared in a $\sim 151 \mathrm{~L}$ (40 gal) plastic drum and diluted in-line during the injection to the required concentration using withdrawn groundwater from well 399-1-7, located $\sim 188.9 \mathrm{~m}(620 \mathrm{ft})$ downgradient from injection well. The concentrated bromide solution consisted of $60.8 \mathrm{~kg}(134 \mathrm{lb}) \mathrm{NaBr}$ mixed with 99.6 L (26.3 gal) of de-ionized water, for an approximate $\mathrm{NaBr}$ concentration of $610 \mathrm{~g} / \mathrm{L}$. The injection stream was maintained at a constant rate of $757 \mathrm{~L}$ (200 gal) per minute throughout the test duration (Figure 6.14). The concentrated solution was delivered to the injection stream at an average flow rate of $0.14 \mathrm{~L} / \mathrm{min}(2.2 \mathrm{gal} / \mathrm{hr})$. This resulted in an average injection concentration of around $112 \mathrm{mg} / \mathrm{L} \mathrm{NaBr}$, or $87 \mathrm{mg} / \mathrm{L} \mathrm{Br}^{-}$; however, due to mechanical problems with the tracer metering pump head, flow rates in the metering pump for the bromide solution varied some during the test (see concentration variability in Figure 6.15). The $\mathrm{NaBr}$ solution was injected into the aquifer through the injection well (399-1-23) for 11.9 hours (714 minutes), yielding a total injection volume of $541,300 \mathrm{~L}$ (143,000 gal). Flow rates for the injection stream during the test were monitored using in-line turbine flow meters and continuously recorded on a data logger (see Figure 6.14).

Table 6.3. Summary of Polyphosphate Treatability Test Site Tracer Injection Test

\begin{tabular}{||l|l||}
\hline \multicolumn{1}{|c|}{ Test Parameter } & \multicolumn{1}{c|}{ Value } \\
\hline \hline Tracer Mass & $60.8 \mathrm{~kg}(134.0 \mathrm{lbs})$ of Sodium Bromide $(\mathrm{NaBr})$ \\
\hline Concentrated Tracer Solution Volume & $26.3 \mathrm{gal}(99.6 \mathrm{~L})$ \\
\hline Total Injection Rate & $200 \mathrm{gal} / \mathrm{min}(757 \mathrm{~L} / \mathrm{min})$ \\
\hline \multicolumn{1}{|c|}{ Conc. Tracer Injection Rate } & $2.2 \mathrm{gal} / \mathrm{hr}(0.14 \mathrm{~L} / \mathrm{min})$ \\
\hline \multicolumn{1}{|c|}{ Make-up Water from 399-1-7 Injection Rate } & $200 \mathrm{gal} / \mathrm{min}$ \\
\hline Injection Concentration & $87 \mathrm{mg} / \mathrm{L} \mathrm{Br}$ \\
\hline Injection Duration & $714 \mathrm{~min}(11.9 \mathrm{hr})$ \\
\hline Injection Volume & $142,600 \mathrm{gal}$ \\
\hline $\begin{array}{l}\text { Unit Abbreviations: } \mathrm{kg}=\text { kilogram; gal }=\text { gallon; } \mathrm{L}=\text { liter; } \mathrm{min}=\mathrm{minute} ; \mathrm{gal} / \mathrm{min}=\text { gallon per minute; } \mathrm{L} / \mathrm{min}= \\
\text { liter per minute; gal/hr = gallon per hour; mg/L = milligrams per liter }\end{array}$ \\
\hline
\end{tabular}




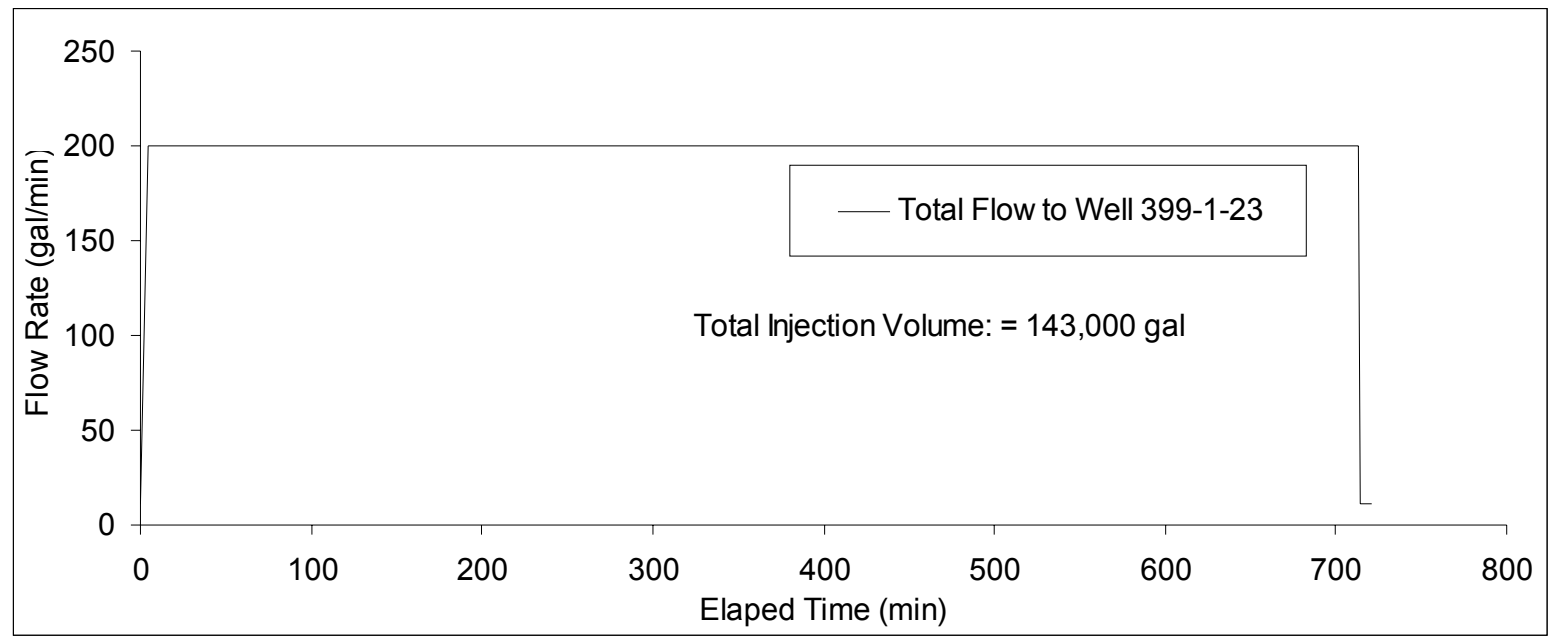

Figure 6.14. Flow Rate, Duration, and Total Injection Volume for Bromide Tracer Test at Polyphosphate Treatability Test Site on December 13, 2006

a)

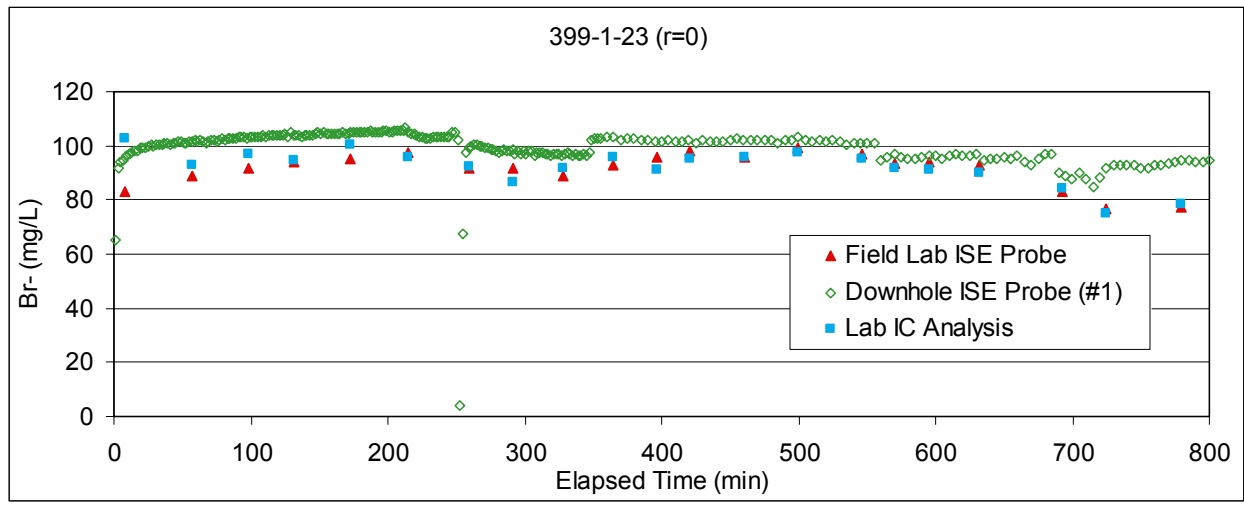

b)

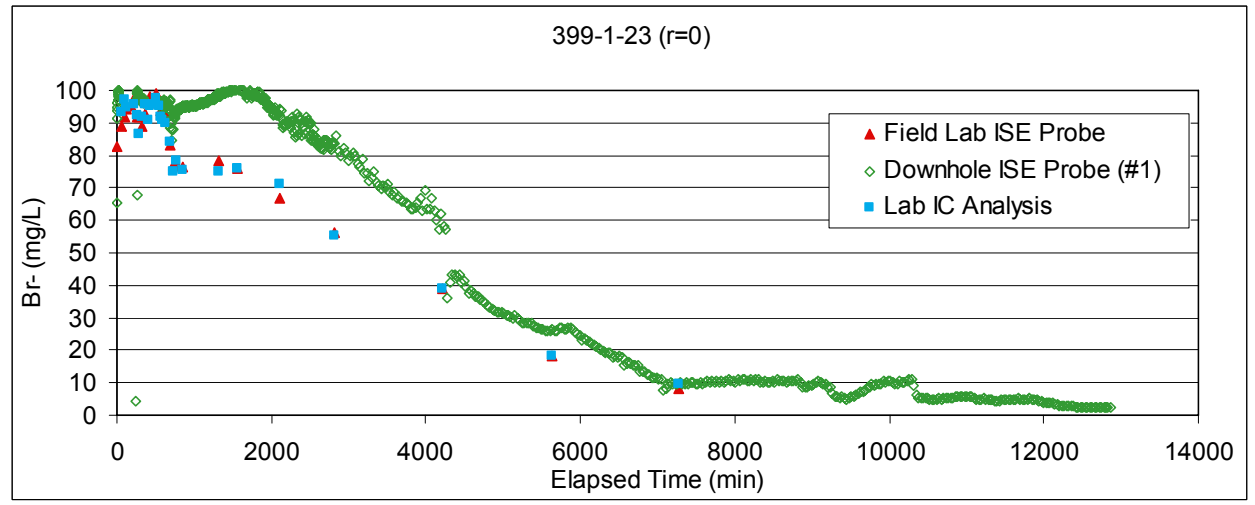

Figure 6.15. Bromide Concentrations for the Tracer Injection Stream During (a) the Injection Period of the Test ( $\mathrm{t}=0$ to $\mathrm{t}=714$ Minutes) and (b) for Several Days Following the Test, as Measured in the Injection Well. Bromide concentrations varied slightly during the test due to minor drift in the metering pump that required periodic adjustment. 
Bromide concentrations were monitored in the injection stream and monitoring wells to determine the effected radial extent of the tracer plume during the test. Downhole ISE probes continuously monitored bromide concentrations in the wells during the test. At total of 256 aqueous samples were collected from the injection stream and surrounding monitoring wells and were analyzed in the field laboratory trailer for bromide using an ISE probe. Specific conductance (SpC), dissolved oxygen (DO), pH, oxidationreduction potential (ORP), and temperature were also measured using an in-line electrode in the sampling manifold. The IC analyses were conducted on each of the 256 archive samples at an offsite laboratory as an additional method of measuring bromide concentration.

\subsubsection{Tracer Test Results and Discussion}

The tracer injection test results provide information on aquifer heterogeneities, effective porosity, expected arrival times and required solution volume for the polyphosphate injection. Bromide BTCs were constructed for all of the wells monitored during the test. The results will be discussed in two groups, wells within the targeted injection volume $(8.8 \mathrm{~m} \mathrm{[29} \mathrm{ft}]$ radial extent) and downgradient wells.

\section{Targeted Injection Volume Monitoring Wells}

Within the targeted injection volume, $50 \%$ bromide concentration arrival times $\left(\mathrm{t}_{50}\right)$ ranged from 16 to 428 minutes (Table 6.4). These results indicate a general correlation between tracer arrival time and radial distance from the injection well, with a few notable outliers. Four of the monitoring wells within the targeted injection volume are fully screened within the aquifer (Figure 6.1) and are useful for horizontal comparisons (Figure 6.16). Wells 399-1-26 (northwest of the injection well) and 399-1-31

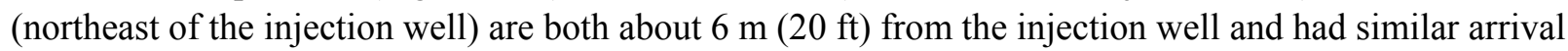
times of 111 and 90 minutes, respectively. Well 399-1-29, located on the perimeter of the targeted

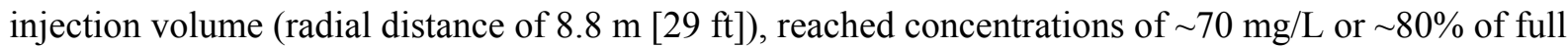
concentration, indicating that this location was near the outer extent of the injection pore volume (PV) in this radial direction.

Well 399-1-30 is an outlier among the other fully-screen wells within the targeted injection volume, showing a much quicker arrival time than the other wells ( $\mathrm{t}_{50}=16$ minutes). The observed early arrival at this location is most likely associated with formational heterogeneities resulting a preferential flow path between the injection well and this monitoring well location.

Assessment of the vertical variability in bromide tracer arrival was possible by comparing the results of adjacent wells screened in upper and lower zones of the aquifer Figure 6.17). Two upper/lower screen well pairs were installed on the downgradient side of the targeted injection volume (Figure 6.1). The 399-1-24/399-1-25 well pair exhibited a similar peak concentration for both depth intervals but the 50\% tracer arrival in 399-1-25 occurred in one-third the time, indicating preferential flow within the lower portion of the aquifer between these two locations.

The other upper/lower screen well pair, 399-1-27 and 399-1-28, showed very different arrival responses for the two intervals. The tracer arrival and peak concentration for 399-1-28, screened in the upper aquifer zone, is similar to other wells within the targeted injection volume. However, bromide arrival response in well 399-1-27, which is screened in the lower zone, showed an unexpectedly slow arrival and low overall concentration at this monitoring location. The BTC shows that the peak bromide ${ }^{-}$ concentration in this well remained below $50 \%$ of the injection stream concentration over the duration of 
the injection (Figure 6.17). Sample purge times for well 399-1-27 were increased during the test to overcome any potential local skin effects in the well; however, this did not effectively increase tracer concentration in the samples. This response, in addition to the relatively low well yields provided by this lower zone monitoring well, suggests that the lower zone of the aquifer at this location is less transmissive than the upper zone at this location or the lower zone at the other well pair location.

Table 6.4. Bromide Tracer Injection Arrival Times and Porosity Results for Targeted Injection Volume Monitoring Wells

\begin{tabular}{|c|c|c|c|c|c|}
\hline Well Name & $\begin{array}{l}\text { Well Screen } \\
\text { Zone }\end{array}$ & Radial Distance (ft) & $\begin{array}{l}50 \% \text { Tracer } \\
\text { Arrival (min) }\end{array}$ & $\begin{array}{l}\text { Average } \\
\text { Velocity } \\
\text { (ft/day) }\end{array}$ & $\begin{array}{c}\text { Estimated Effective } \\
\text { Porosity }\end{array}$ \\
\hline $399-1-23$ & Full & 0 & - & - & - \\
\hline 399-1-24 & Upper & 14.9 & 124 & 168 & 0.33 \\
\hline $399-1-25$ & Lower & 14.4 & 39 & 519 & 0.11 \\
\hline $399-1-26$ & Full & 19.9 & 111 & 260 & 0.16 \\
\hline 399-1-27 & Lower & 24.5 & 428 & 81 & N.C. \\
\hline $399-1-28$ & Upper & 24.9 & 216 & 162 & 0.21 \\
\hline 399-1-29 & Full & 29.6 & 165 & 254 & 0.11 \\
\hline 399-1-30 & Full & 14.8 & 16 & 1300 & - \\
\hline \multirow[t]{2}{*}{ 399-1-31 } & Full & 19.6 & 90 & 316 & N.C. \\
\hline & & & & & Average $=0.18$ \\
\hline
\end{tabular}

The tracer arrival times were used to estimate the effective porosity of the aquifer according to the following equation:

where $n=$ effective porosity

$$
n=\frac{t_{50} \cdot Q_{t o t}}{\pi \cdot r^{2} \cdot L \cdot 7.48}
$$

$t_{50}=50 \% \mathrm{Br}^{-}$concentration arrival time (minutes)

$Q_{t o t}=$ total injection rate $(200 \mathrm{gpm})$

$r=$ radial distance from the injection well (feet)

$L=$ aquifer thickness (15 feet)

Effective porosities were calculated for each of the 8 monitoring wells in the targeted injection volume, except for the two outlier wells (Table 6.4). Values range from 11 to $33 \%$ for the different wells, with an average effective porosity of $18 \%$. This value is consistent with porosity estimates from the LFI that were based on physical property analysis (Williams et al. 2007). 
a)

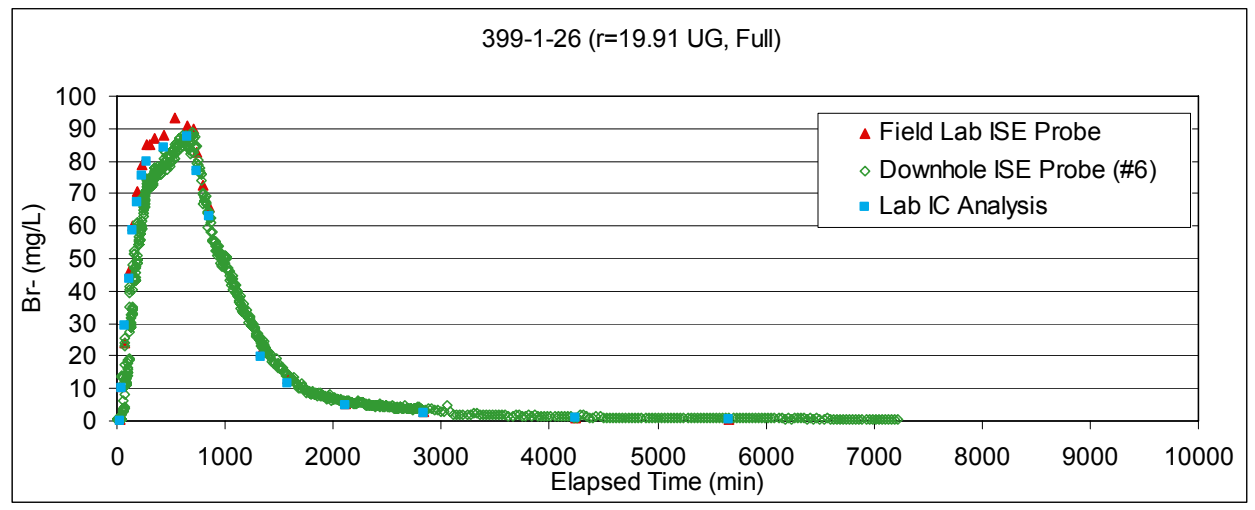

b)

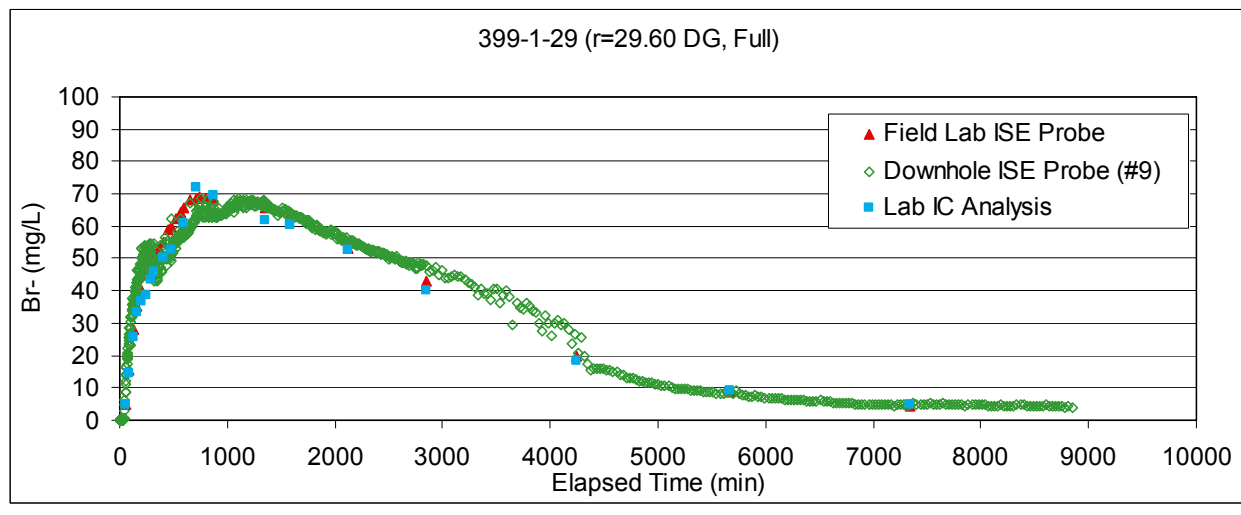

c)

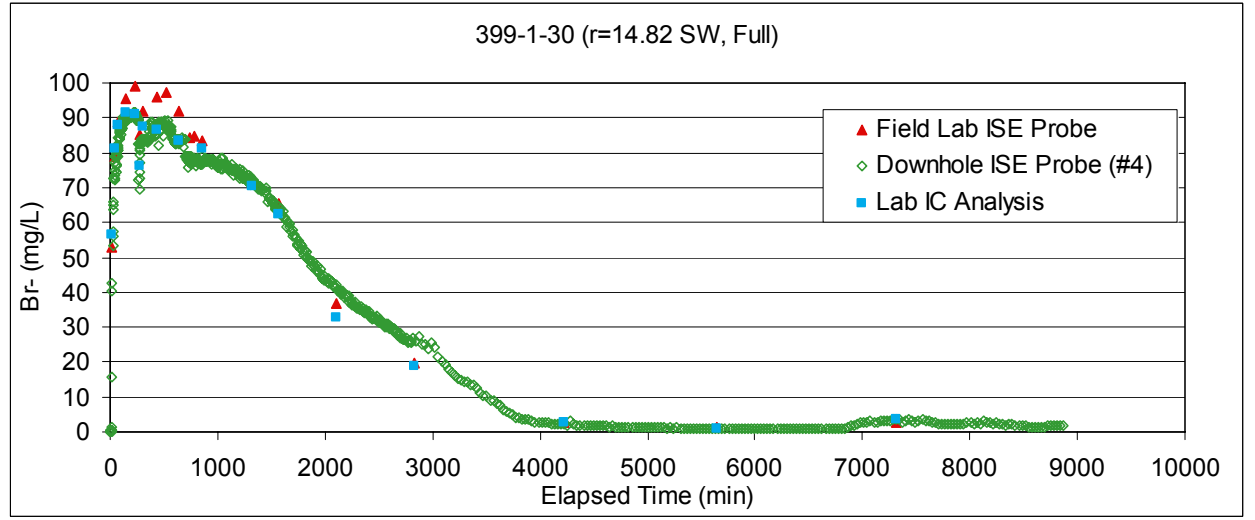

d)

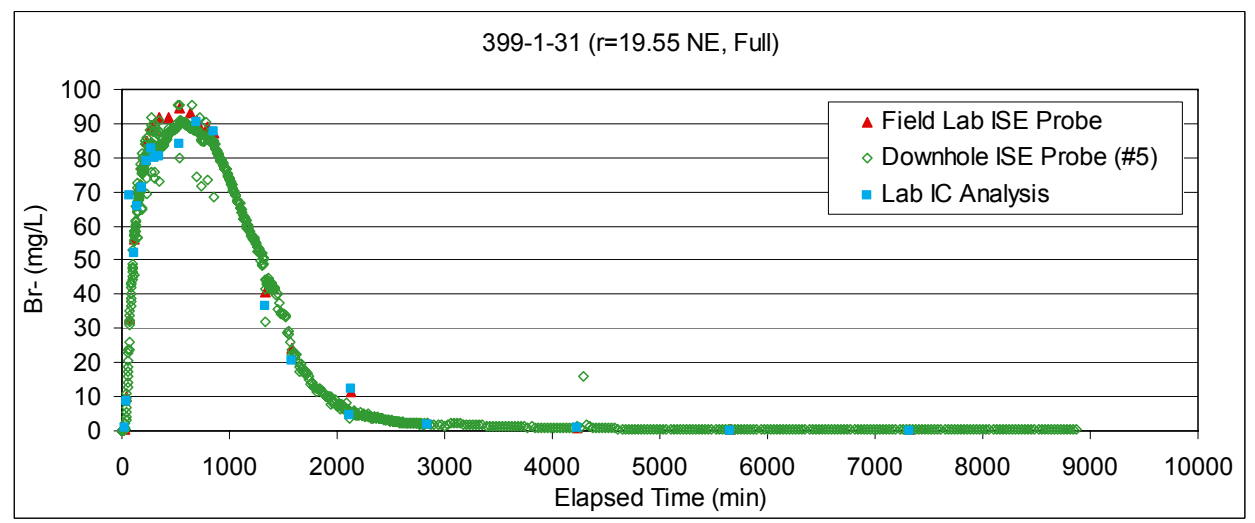

Figure 6.16. Breakthrough Curves (BTC) Showing Bromide Concentrations through Time for FullyScreened Wells Within the Targeted Injection Volume: a) 399-1-26, b) 399-1-29, c) $399-1-30$, and d) $399-1-31$ 
a)

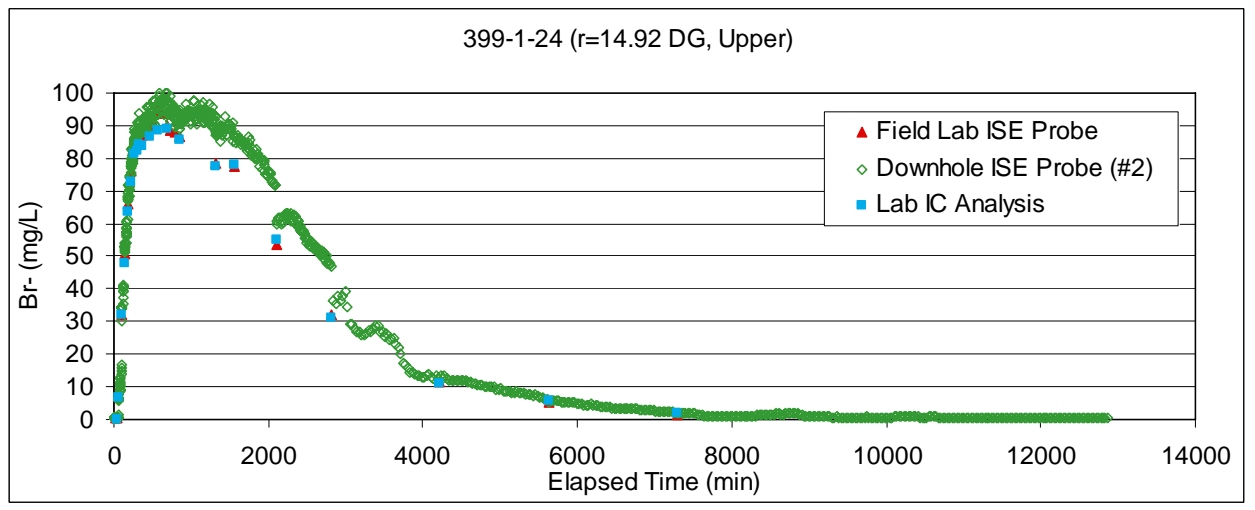

b)

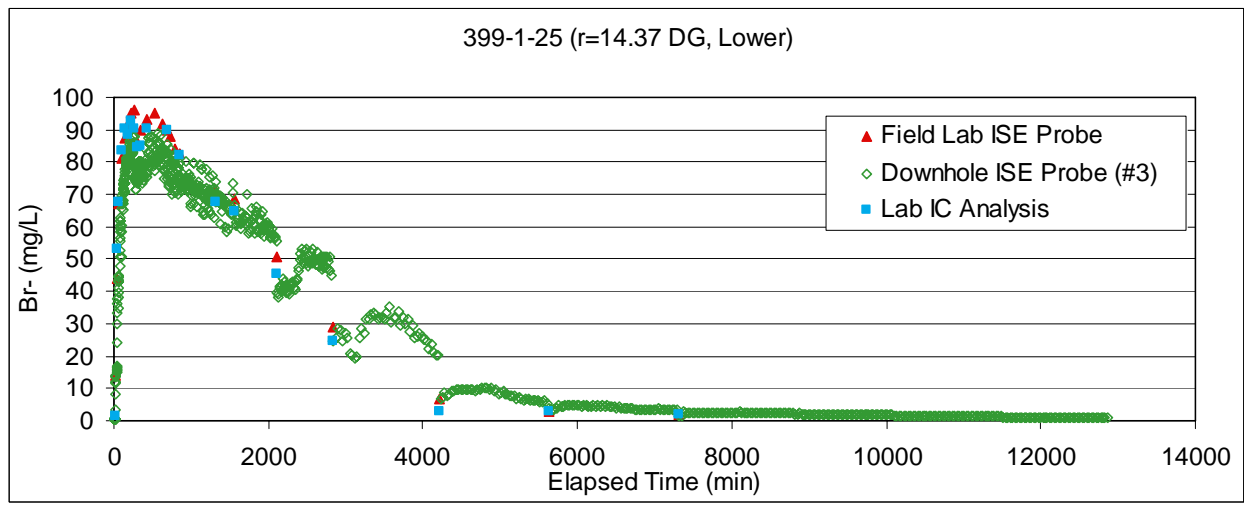

c)

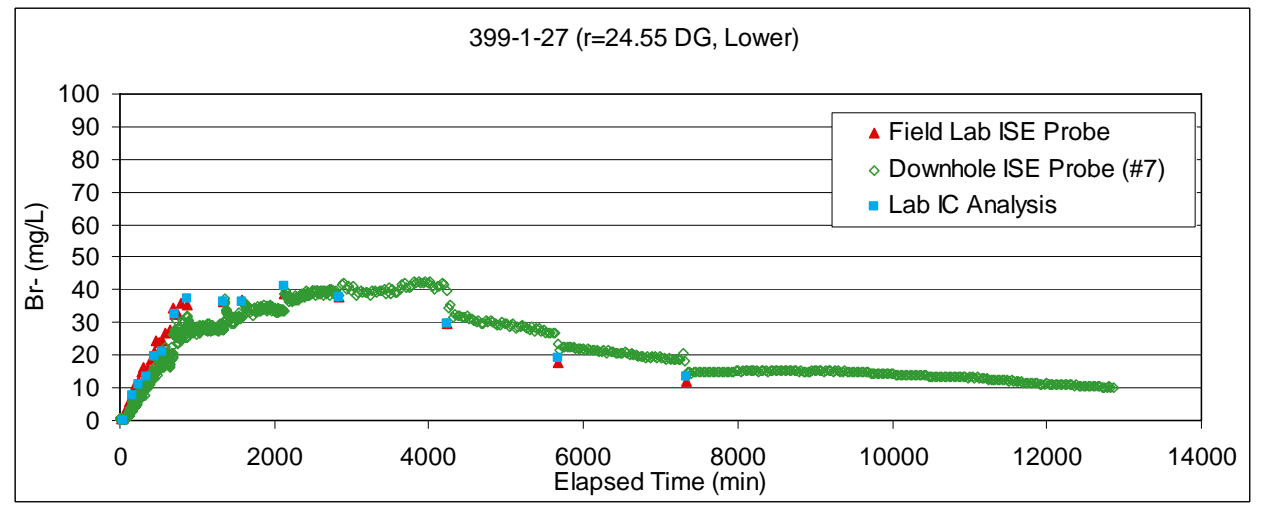

d)

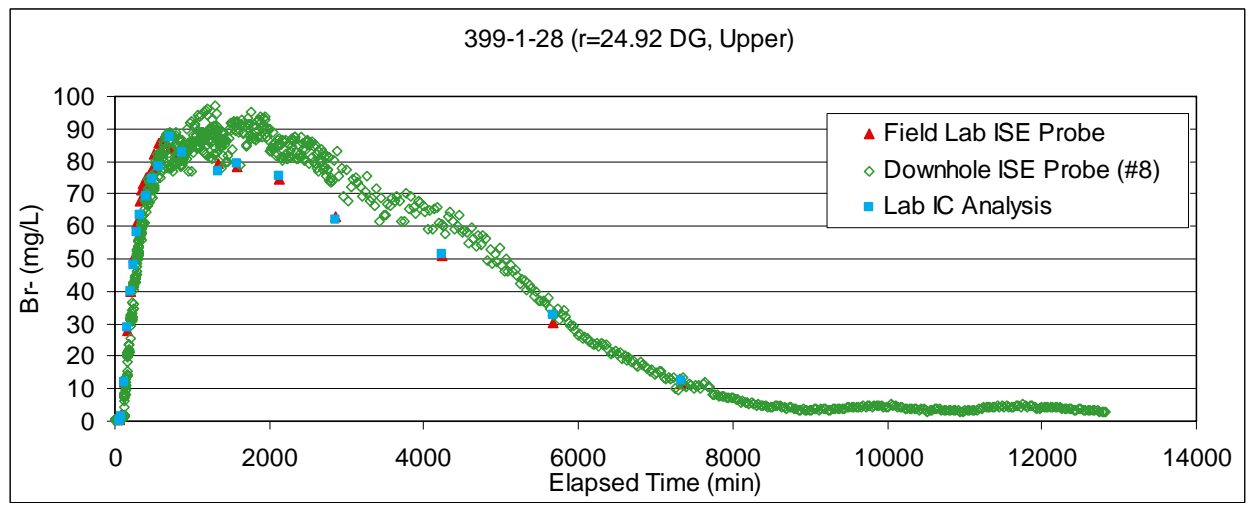

Figure 6.17. Breakthrough Curves (BTC) Showing Bromide Concentrations through Time for Wells Within the Targeted Injection Volume that are Screened in Only the Upper or Lower Zones of the Aquifer: a) $399-1-24$, b) 399-1-25, c) 399-1-27, and d) 399-1-28 


\section{Downgradient Monitoring Wells}

Several monitoring wells are located downgradient from the injection well beyond the radial extent of the targeted injection volume (Figure 6.18). These include wells 399-1-32 and 399-1-7, located 104 and 617 feet from the injection well, respectively. By combining the results from the bromide tracer drift with water level measurements, and the resulting hydraulic gradient calculations, it is possible to estimate hydraulic conductivity $(K)$ according to Darcy's Law:

$$
\begin{aligned}
& v=\frac{K}{n} \cdot \frac{d h}{d x} \\
& K=\frac{v \cdot n}{\frac{d h}{d x}}
\end{aligned}
$$

where $K=$ hydraulic conductivity (ft/day)

$v=$ groundwater velocity based on the tracer arrival time (ft/day)

$n=$ average effective porosity from the tracer arrival times (18\% from above)

$\mathrm{dh} / \mathrm{dx}=$ time-weighted average hydraulic gradient during tracer transport $(\mathrm{ft} / \mathrm{ft})$

The BTC for well 399-1-32 (Figure 6.18) shows an early arrival response in the tracer concentration data ahead of the main peak arrival, indicating the presence of formational heterogeneities that result in a faster flow path between the injection well and this location that could not be explained by transport through a homogeneous porous media. For this reason, hydraulic conductivities were estimated for both the interpreted preferential flow path resulting in an early tracer arrival and the bulk porous media attributed to transport of the main plume body.

For the main tracer plume arrival at well 399-1-32, the groundwater velocity was estimated at $\sim 15.24 \mathrm{~m}(50 \mathrm{ft})$ per day during tracer transport, based on a radial distance of $31.69 \mathrm{~m}(104 \mathrm{ft})$ and a tracer transport duration of $\sim 3,000$ minutes (Table 6.5). The tracer drift duration was defined as the time period between the end of the test when the tracer plume was centered over the injection well $(\mathrm{t}=$ 714 minutes) and the arrival time of the center of mass at 399-1-32 ( $t=\sim 3,700$ minutes). The timeweighted average gradient during tracer transport between the injection well and 399-1-32, as determined from water-level measurements, was $\sim 6.5 \mathrm{E}-4 \mathrm{ft} / \mathrm{ft}$. The estimated hydraulic conductivity using these parameters is about $4,300 \mathrm{~m}(14,000 \mathrm{ft})$ per day.

The fast-path hydraulic conductivity was calculated using the same equation used for the main tracer plume, but with some notable differences in the sources of the parameter values. For example, the timeweighted average hydraulic gradient was calculated using wells other than the injection well. The gradient observations between the injection well and well 399-1-32 would not be representative of the true spatially distributed gradient between the two wells since the gradient would likely be artificially high due to the inherent well inefficiencies in the injection well. To avoid this biasing, gradients were calculated suing head data from wells transverse to the injection well (wells 399-1-30 and 399-1-31). Since the fast-path tracer arrival at well 399-1-32 occurred during the injection phase of the test, the transport duration was defined as the time between the beginning of the injection test $(\mathrm{t}=0)$ and the $50 \%$ 
a)

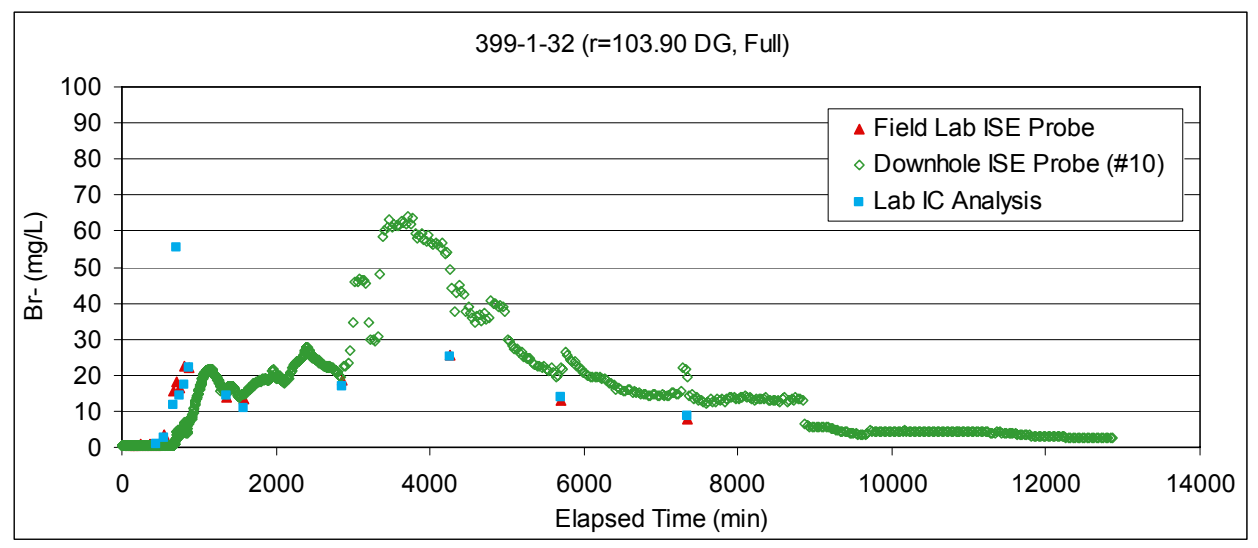

b)

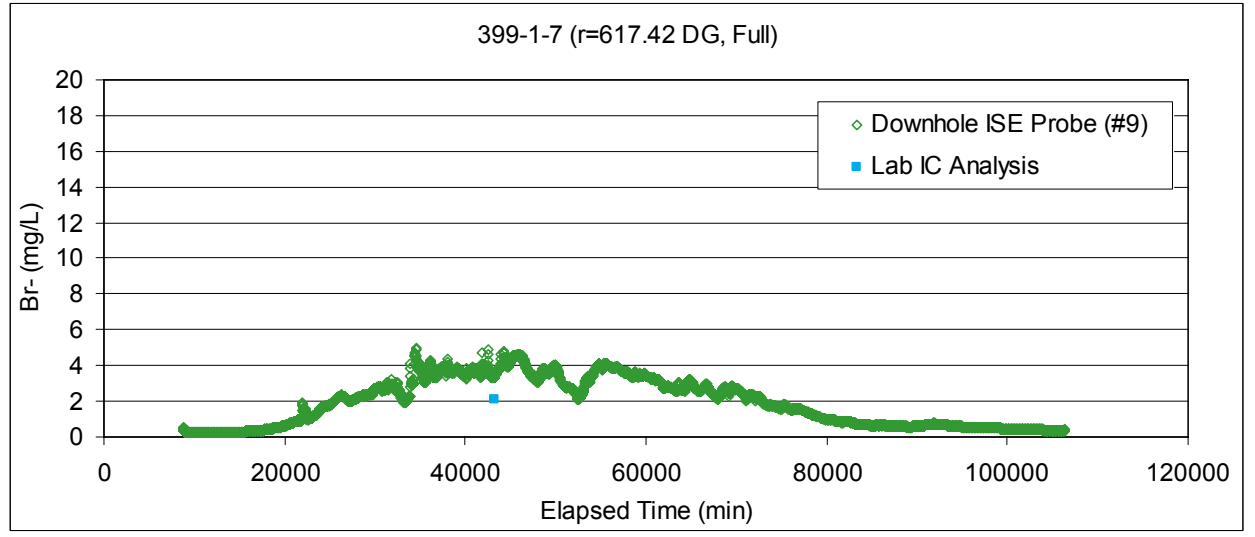

Figure 6.18. Breakthrough Curves (BTC) Showing Bromide Concentrations through Time for Downgradient Wells a) 399-1-32 and b) 399-1-7.

Table 6.5. Summary of Parameters Used to Estimate Hydraulic Conductivity Between Injection Well 399-1-23 and Downgradient Well 399-1-32 for Main Body of Tracer

\begin{tabular}{||c|c|c|c|c|c|}
\hline \hline $\begin{array}{c}T_{\text {Time }}^{\text {start }} \\
\text { (elapsed } \\
\text { minutes) }\end{array}$ & $\begin{array}{c}\text { Time }_{\text {end }}{ }^{(\mathrm{b})} \\
\text { (elapsed } \\
\text { Minutes) }\end{array}$ & $\begin{array}{c}\text { Transport } \\
\text { Duration }^{(\mathrm{c})} \\
\text { (minutes) }\end{array}$ & $\begin{array}{c}\text { Groundwater } \\
\text { Velocity (ft/day) }\end{array}$ & $\begin{array}{c}\text { Time-weighted } \\
\text { Average Hydraulic } \\
\text { Gradient (ft/ft) }\end{array}$ & $\begin{array}{c}\text { Hydraulic } \\
\text { Conductivity } \\
\text { (ft/day) }\end{array}$ \\
\hline \hline 714 & $\sim 3700$ & $\sim 3000$ & $\sim 50$ & $\sim 6.5 \mathrm{E}-4$ & $\sim 14,000$ \\
\hline
\end{tabular}

(a) Time when tracer plume was centered on injection well 399-1-23. This was the end of the test.

(b) Time when tracer plume arrives at 399-1-32.

(c) Time duration of tracer transport between injection well 399-1-23 and 399-1-32; defined as Time end - Time $_{\text {start }}$. Note: An effective porosity value of $18 \%$ was used in calculating the hydraulic conductivity estimate.

tracer concentration arrival time at well 399-1-32 $(\mathrm{t}=\sim 930)$. The calculated groundwater velocity estimate based on this arrival time and the radial distance to the injection well is $\sim 48.76 \mathrm{~m}$ (160 ft) per day. These parameters resulted in fast-path hydraulic conductivity estimates of 6,705 and $7,010 \mathrm{~m}$ (22,000 and 23,000 ft) per day based on gradients measured from wells 399-1-31 and 399-1-30, respectively. This fast path velocity if almost two times the hydraulic conductivity estimate based on transport of the bulk tracer plume. 
The breakthrough curve for well 399-1-7, the more distant downgradient monitoring well (radial distance $=188 \mathrm{~m}[617 \mathrm{ft}]$ ), shows much more dispersed tracer plume arrival (Figure 6.18). The fist arrival of the tracer occurred after $\sim 12$ days (17,280 minutes) and steadily increased in concentration to a maximum of about $5 \mathrm{mg} / \mathrm{L}$ around the 30 day mark (43,200 minutes). Although first arrival of the tracer plume at this location is generally consistent with the $15.24 \mathrm{~m}(50 \mathrm{ft})$ per day velocity calculated from the

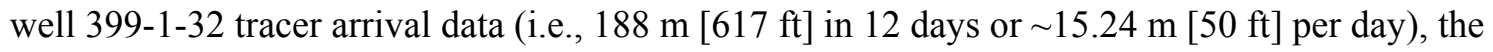
dispersed nature of this arrival response and the variability in groundwater velocity and flow direction over the relatively long travel path preclude a quantitative velocity or hydraulic conductivity estimate using these data.

Overall, the results from the bromide tracer injection test present some important information for design of the future polyphosphate treatability test. For example, the 541,313 L (143,000 gal) injected during the tracer test appears to be a suitable volume to impact the full 9-m (30-ft) radial extent of the targeted tracer injection volume. Even well 399-1-32, located $31.69 \mathrm{~m}$ (104 ft) downgradient from the injection well, received over $70 \%$ tracer concentration after a two-day drift period. The test results also suggest there are heterogeneities in the aquifer which affect groundwater transport within and downgradient of the targeted treatment zone. Results from wells 399-1-27 and 399-1-29, when viewed in comparison to results from the other wells, indicate there is a less permeable zone in the lower part of the aquifer in the vicinity of well 399-1-27. However, it is not clear from these results just how laterally extensive this zone is. The porosity estimate of $18 \%$, calculated using the arrival times in the targeted treatment zone, is consistent with other reported values (Williams et al. 2007). Lastly, the equipment and sampling methods and intervals used in the tracer test were successful and would likely be suitable for the upcoming polyphosphate injection.

The simplified approach for evaluation of tracer injection and transport data discussed in this section provides for a good estimate of treatability test-scale transport properties and forms the basis for a more technically rigorous evaluation. Additional discussion regarding evaluation of the tracer injection data using a local-scale flow and transport model is provided in Section 6.6.

\subsection{Hydraulic Test Results}

This section describes analysis of pressure buildup data collected during the bromide tracer injection test and slug withdrawal tests conducted in several of the site monitoring wells prior to the tracer test. As discussed in Section 6.3, operation of the tracer test involved injecting a large volume of water at a constant rate into well 399-1-23. Water-levels in nearby monitoring wells responded to this injection in small but discernible buildups in pressure, which were analyzed using constant-rate pumping test analysis methods. Since water levels in monitoring wells also respond to changes in river stage in similar magnitudes, pressure data were first corrected to remove this effect. The correction made to the pressure buildup data is described below, followed by a discussion of the hydraulic analysis results.

\subsubsection{River Response Correction}

Given their proximity to the river, all of the wells within the polyphosphate treatability test site monitoring network respond to changes in the elevation of the Columbia River. Data showing a typical relationship between fluctuating river stage and aquifer response is shown in Figure 6.19, which is representative of the type of response in site monitoring wells. As indicated in Figure 6.19, the impact of river stage variability at the monitoring well locations is both time-lagged and attenuated. This 
river-induced effect was characterized by analyzing several weeks of well pressure and river stage data following the tracer injection test. Distinct cycles of river stage fluctuations were identified and correlated to their resulting time-lagged and attenuated pressure responses. The peak-to-peak and trough-to-trough time lags and change in elevation magnitudes between the river and wells were compared. From this examination, it was determined that the response time lag was approximately 360 minutes (6 hrs), and attenuated to approximately 5\% of the river response.

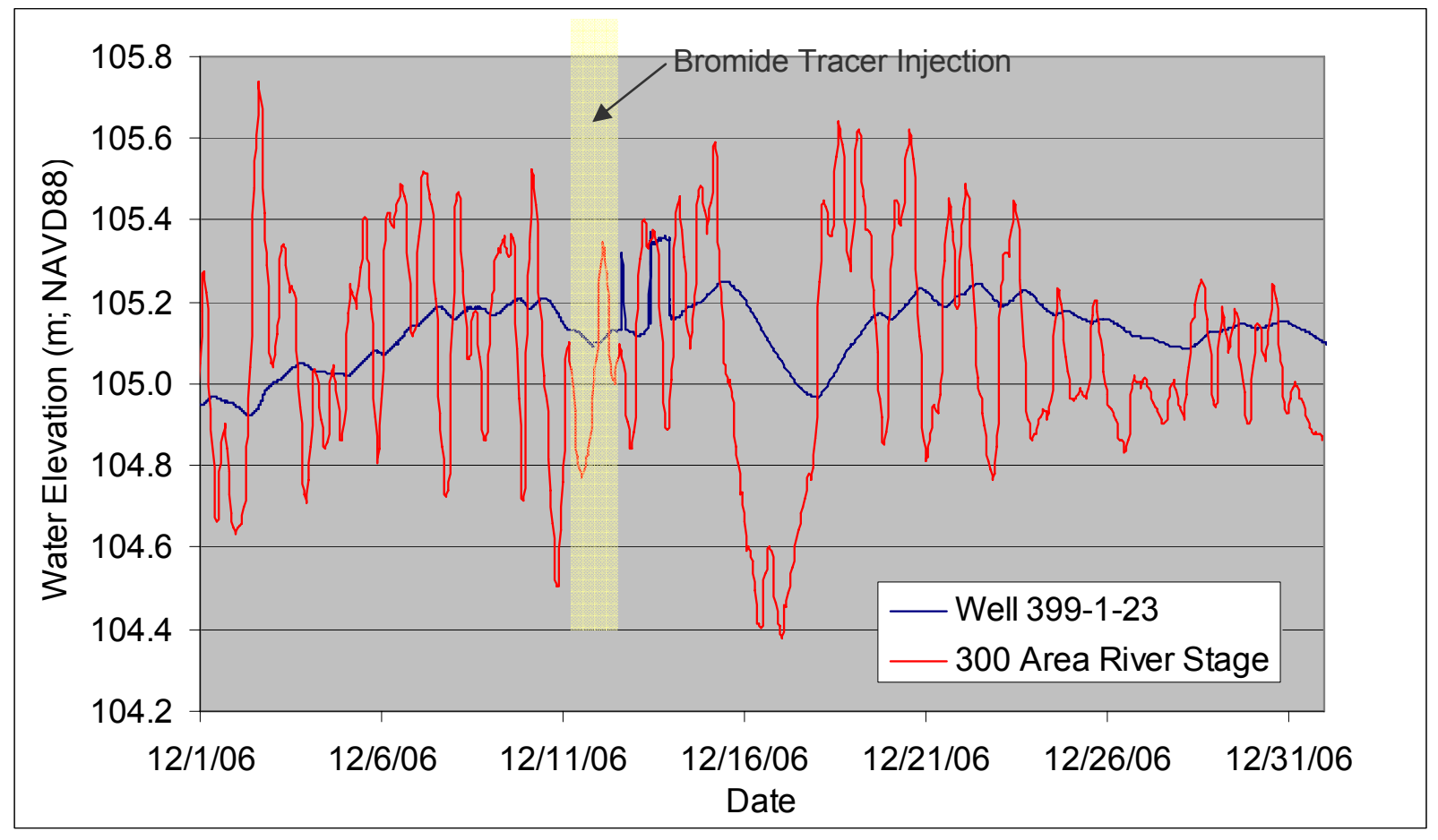

Figure 6.19. Relation Between Changing River Stage (red line) and Time-Lagged and Attenuated Response in Well 399-1-23 for Several Weeks Prior to and Following Tracer Injection Test (blue line). This response is representative for other wells in the monitoring network.

These time-lag and attenuation factors were then used to correct the pressure buildup observations according to the following equation:

$$
h_{c o r}=h_{w}\left(\Delta h_{r} \cdot \alpha\right)
$$

where $h_{c o r}=$ corrected head in the monitoring well

$h_{w}=$ uncorrected head

$\Delta h_{r}=$ change in river stage that occurred 360 minutes previously (time lag)

$\alpha=$ attenuation factor $(0.05)$

This simple correction method was first used on a period of background water levels in well 399-1-23 in order to evaluate its effectiveness (Figure 6.20). Although this simple correction method does not fully correct for river effects, particularly for the smaller short-term river fluctuations, it does effectively dampen the magnitude of river-induced water-level changes. A preliminary evaluation of the multipleregression deconvolution technique (Spane 2002; Rasmussen and Crawford 1997) was initially pursued to 
see if the trend removal effectiveness could be improved. However, because the required level of correction during the pressure buildup portion of the test was relatively small (see discussion below), this effort was not pursued further.

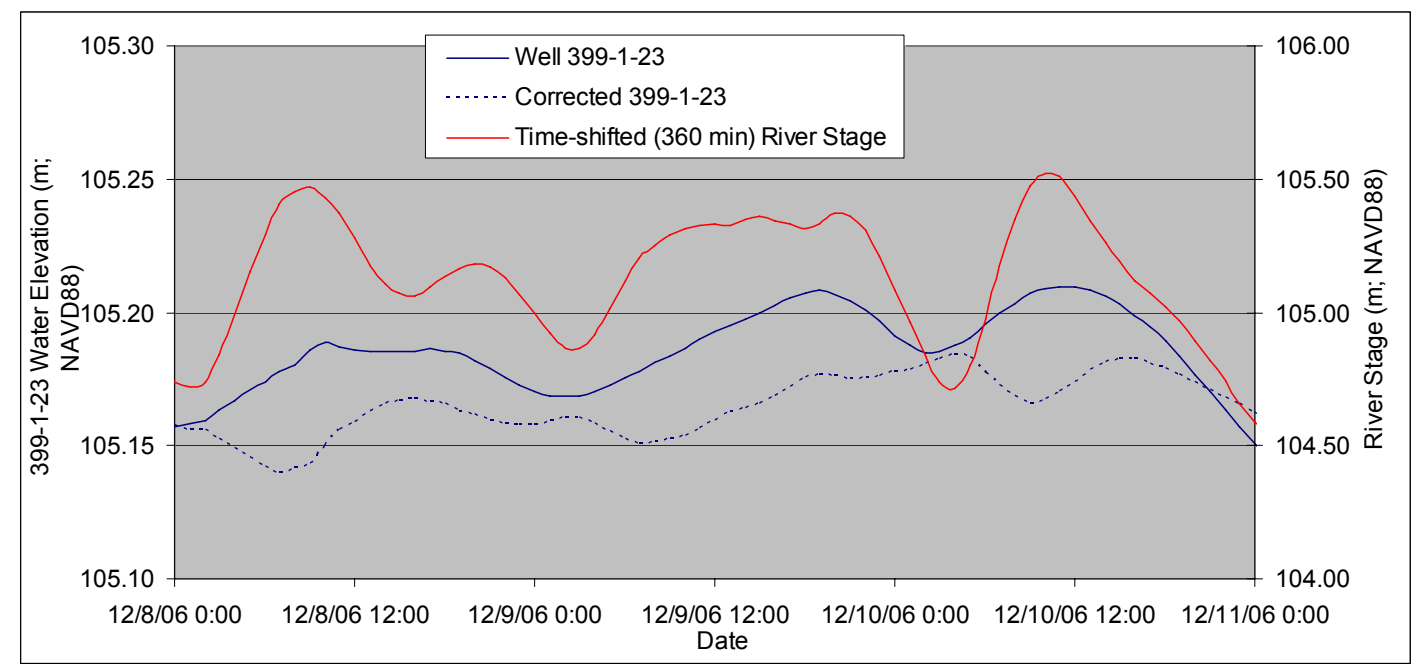

Figure 6.20. Plot Showing an Example of Water Elevations Before (solid blue line) and After Correction (dotted blue line) for River-Stage Fluctuations (red line) for Well 399-1-23 During Background Water Levels Several Days Prior to the Injection Test. A time lag of 360 minutes and an attenuation factor $(\alpha)$ of 0.05 were used in the correction.

The correction method outlined above was then performed on the pressure buildup data. In general, the corrected pressures differed very little from the uncorrected values. This is due to the fact that the river-stage conditions which would be expected to cause water-level effects during the test (i.e., time lag $=360 \mathrm{~min}$ ) were relatively stable during this time period, changing only a few centimeters in elevation (Figure 6.21). Figure 6.22 shows an example of pressure buildup data for well 399-1-26 that have been corrected for river-induced pressure effects, as well as the uncorrected data. Although these

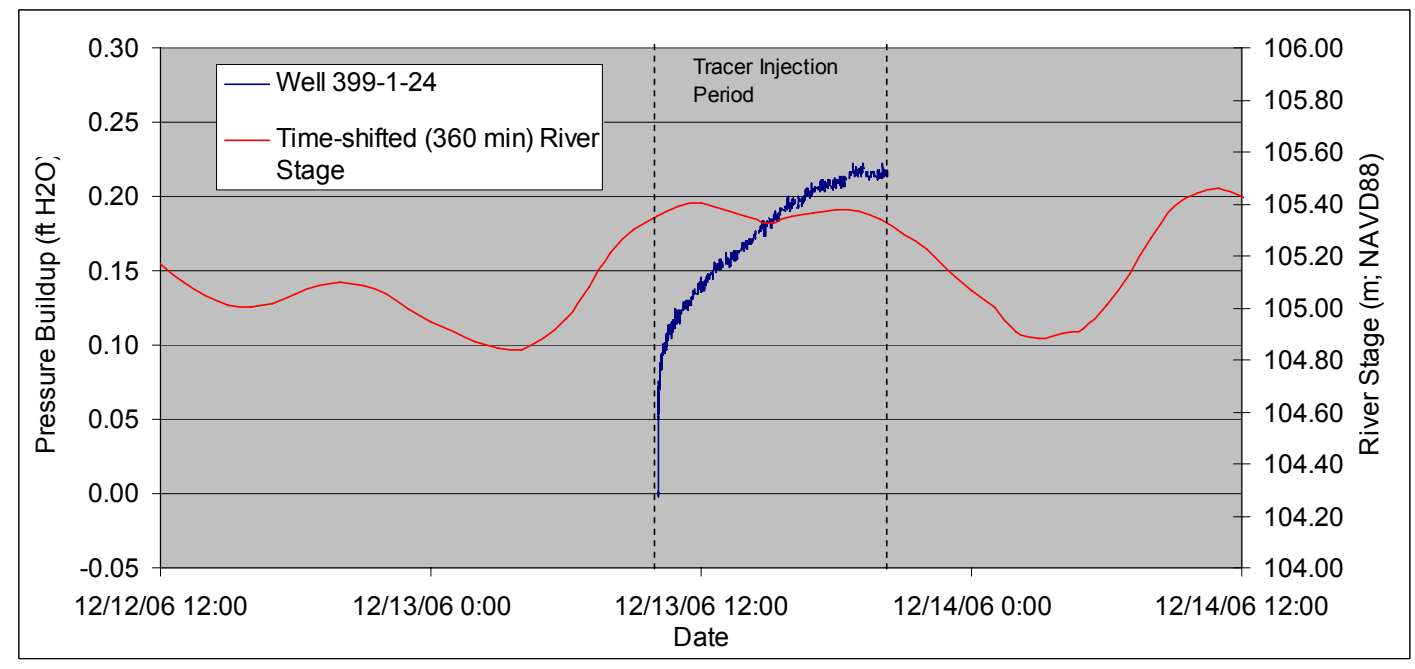

Figure 6.21. Plot Showing Changing River Conditions (time shifted 360 minutes) During the Period of Pressure Buildup During the Injection Test for the Monitoring Well 399-1-24 


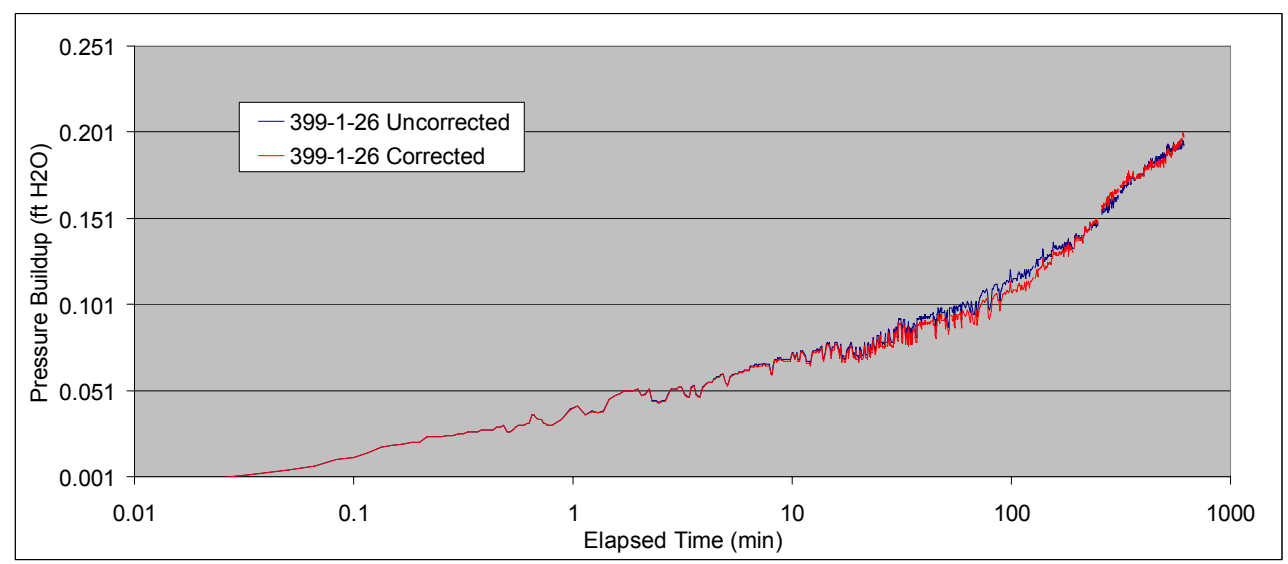

Figure 6.22. Corrected (red line) and Uncorrected (blue line) Pressure Buildup Data for the Monitoring Well 399-1-26. Gaps of missing data represent data points that were filtered out of the analysis since they were skewed due to pumping water samples from the wells at these times.

small corrections are unlikely to have a significant impact on the hydraulic analysis results discussed below, corrected data were still used in the analysis. The average pressure buildup within the monitoring wells was $\sim 0.20$ feet of water (Table 6.6).

\subsubsection{Hydraulic Test Analysis}

Pressure buildup data collected during the 11.9-hour tracer injection test, which was conducted at a constant rate and can be analyzed using the same analytical techniques for analyzing constant rate discharge tests (i.e., pumping tests), was used to provide local-scale estimates of hydraulic properties for the Hanford formation at this site. Test response data were analyzed using AquiferTest Pro, a software package developed by Waterloo Hydrogeologic, a Schlumberger Company. The analytical approach utilized is a solution developed by Neuman (1975) for pumping test response in an unconfined, anisotropic aquifer, which incorporates the "delayed yield" effect associated with unconfined aquifers. The method can be used for either fully or partially penetrating wells and assumes the aquifer is homogeneous and infinite in extent.

Table 6.6. Pressure Buildup Summary for Monitoring Wells during the 2006 Bromide Tracer Injection Test

\begin{tabular}{||c|c|c|c||}
\hline Well Name & Well Screen Zone & Radial Distance $(\mathrm{ft})$ & Total Pressure Buildup $\left(\mathrm{ft} \mathrm{H}_{2} \mathrm{O}\right)$ \\
\hline \hline $399-1-24$ & Upper & 14.9 & 0.22 \\
\hline $399-1-25$ & Lower & 14.4 & 0.22 \\
\hline $399-1-26$ & Full & 19.9 & 0.20 \\
\hline $399-1-27$ & Lower & 24.5 & 0.21 \\
\hline $399-1-28$ & Upper & 24.9 & 0.18 \\
\hline $399-1-29$ & Full & 29.6 & 0.14 \\
\hline $399-1-30$ & Full & 14.8 & 0.22 \\
\hline $399-1-31$ & Full & 19.6 & 0.18 \\
\hline & & & Average $=0.20$ \\
\hline
\end{tabular}


Although the heterogeneities observed in the tracer arrival data would indicate that the requirement for homogeneous aquifer conditions was not fully met for the Hanford unconfined aquifer beneath the polyphosphate treatability test site, this analytical technique can still be used to provide quantitative estimates of hydraulic properties and to provided insight into the spatial variability of hydraulic properties at the site.

In general, most of the monitoring wells located within the targeted treatment zone showed a similar response, examples of which are shown in Figures 6.23 through 6.25 for a fully screened well (399-1-26) and one of the upper/lower zone well pairs (399-1-24 and 399-1-25, respectively). These plots show the pressure buildup data plotted along with the Neuman type curves (storativity response in blue, delayed yield in black) and include a summary of model inputs above the plot and a summary of hydraulic property estimates below.

The Neuman type-curve analyses resulted in an estimated hydraulic conductivity of $\sim 2,800 \mathrm{~m}$ $(9,300 \mathrm{ft})$ per day. The specific yield was prescribed at 0.18 to be consistent with the effective porosity estimate obtained from the tracer arrival data (see Table 6.4) and the anisotropy ratio was prescribed at 0.1 , which is a typical values used for alluvial and glaciofluvial aquifers. It should be noted that the time versus drawdown data in these plots are displayed as dimensionless values, which is a requirement of the analysis package. For actual response times and the magnitude of pressure buildup, which were generally on the order of $0.06 \mathrm{~m}(0.2 \mathrm{ft})$, see Table 6.6 and Figure 6.22.

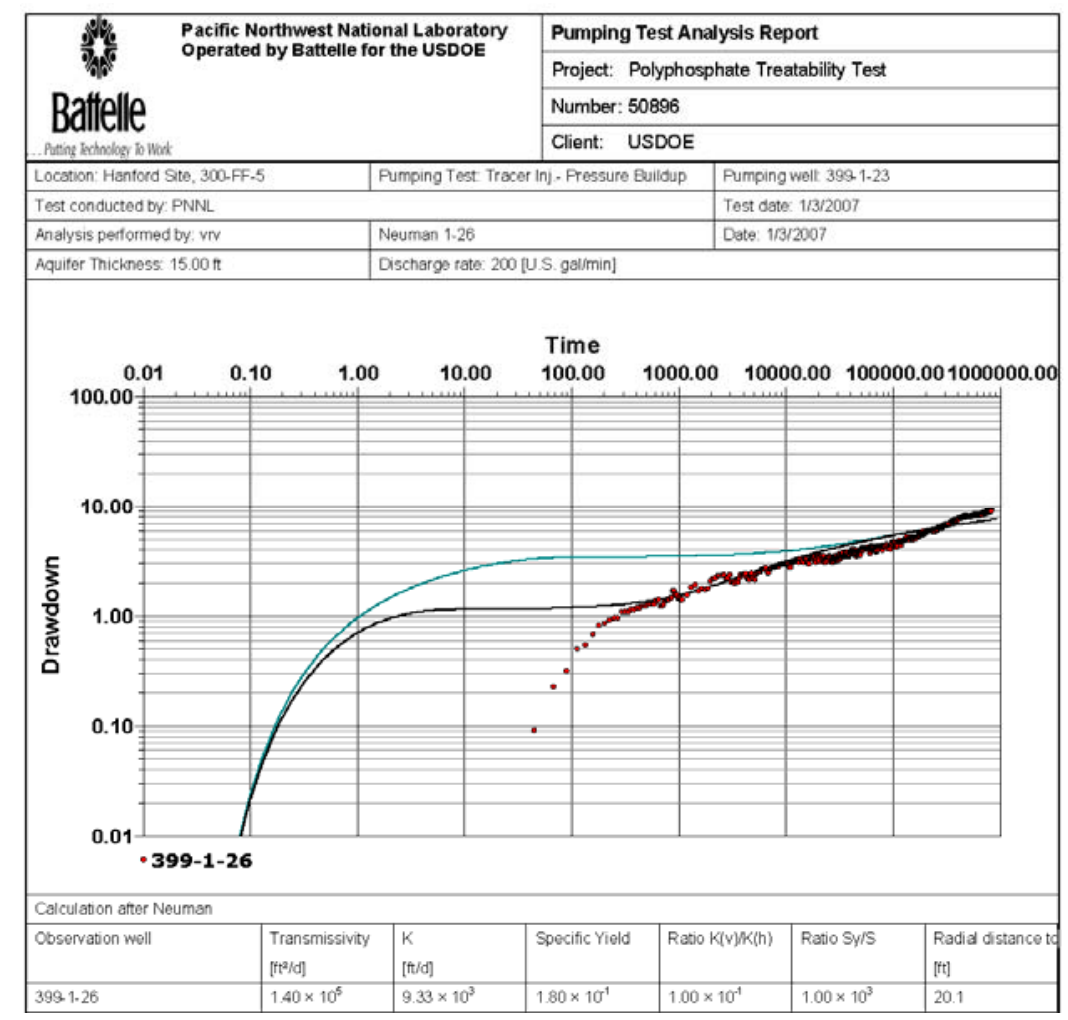

Figure 6.23. Neuman Type-Curve Analysis of Pressure Buildup Data at Well 399-1-26 


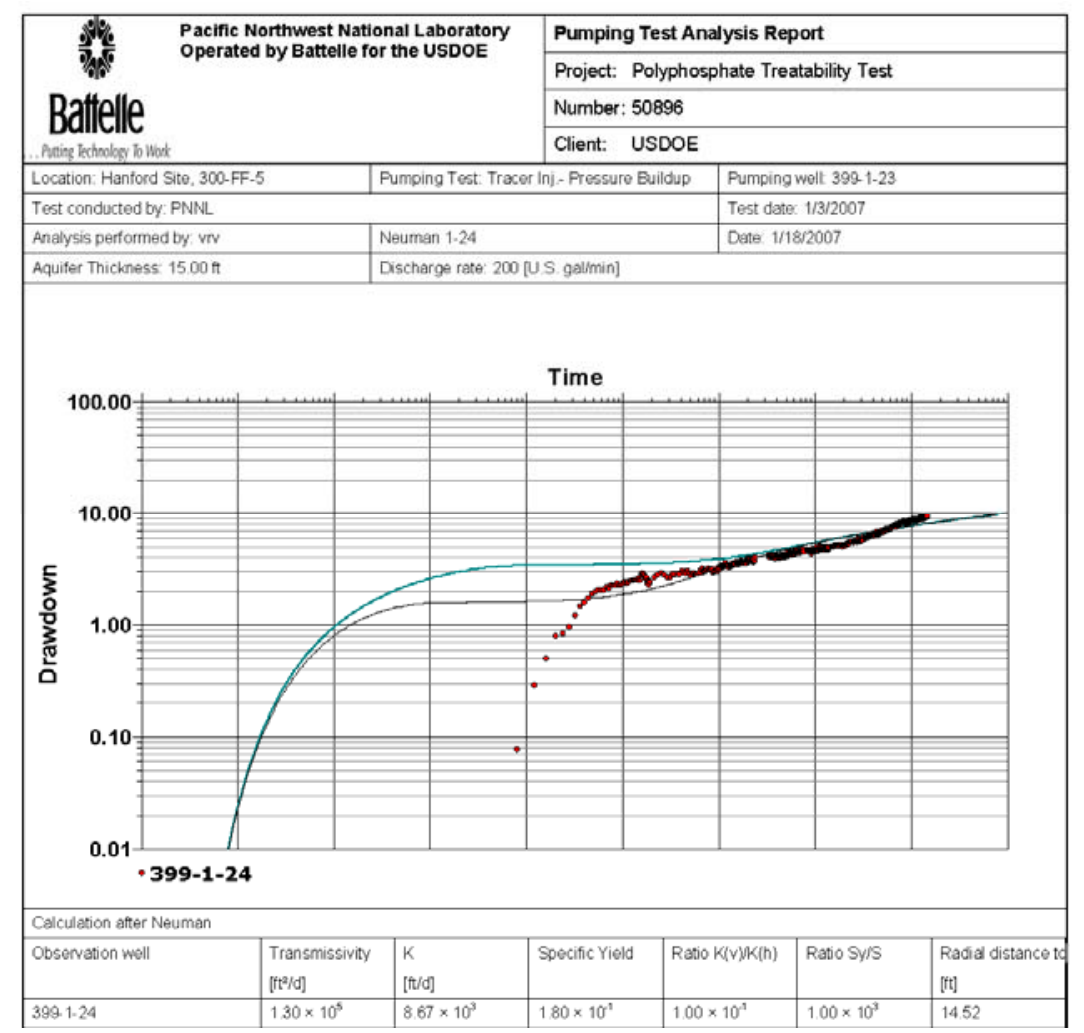

Figure 6.24. Neuman Type-Curve Analysis of Pressure Buildup Data at Well 399-1-24

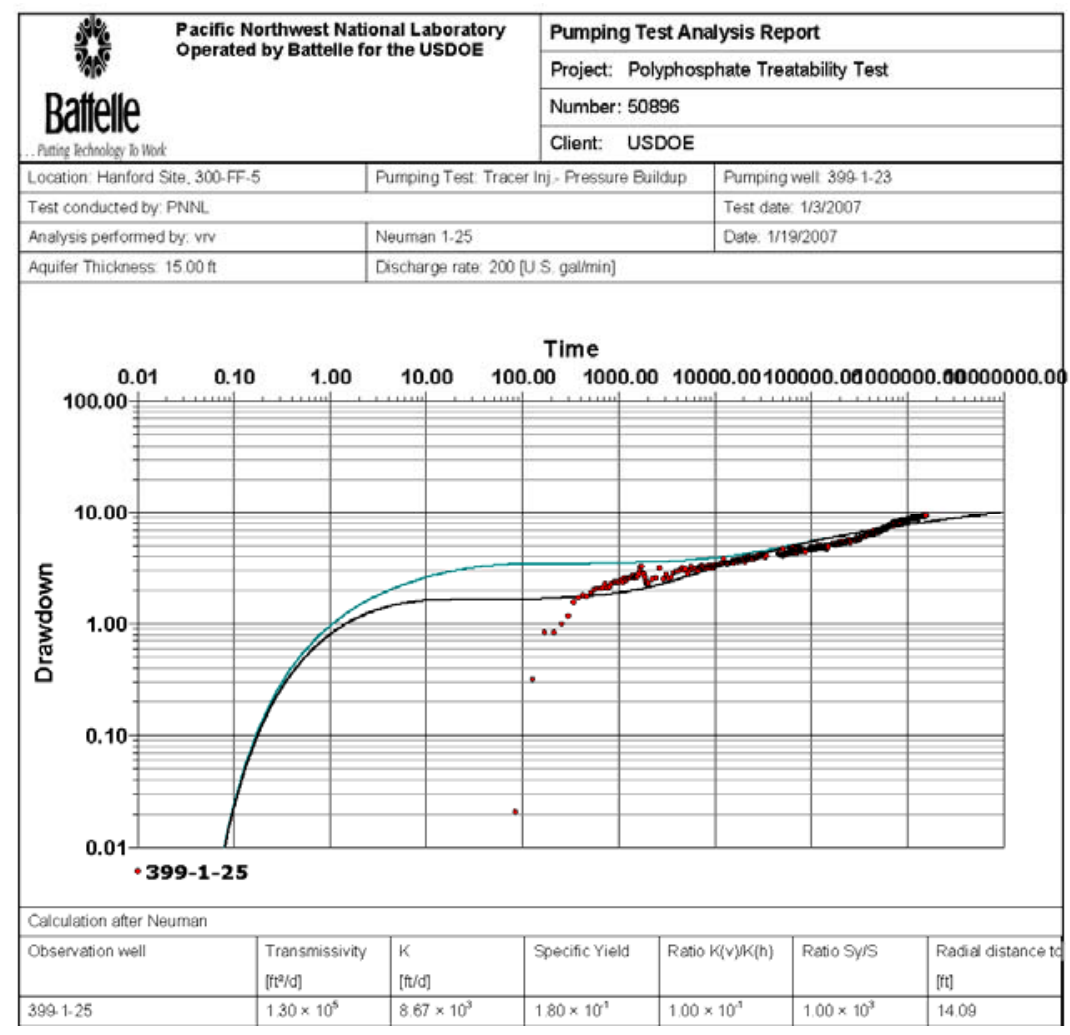

Figure 6.25. Neuman Type-Curve Analysis of Pressure Buildup Data at Well 399-1-25 
As indicated by Figures 6.23 through 6.25, early-time pressure buildup data does not follow the elastic or early delayed yield response predicted by the Neuman method. In this high permeability formation, the time over which this early response occurs is extremely small. The earliest portion of the pressure buildup data shown on these plots represents an initial elapsed time of 1 second and subsequent data collected on a 1-second-sampling interval. As can be seen from this data plotted as dimensionless time, the early-time Neuman response occurs over a fraction of a second and would not be observable except under the most controlled of test conditions. Test response data continued to deviate from the predicted response for 10 to 20 seconds into the test. This early time discrepancy is most likely associated with the non-ideal test conditions at the start of the injection (i.e., because the injection makeup waster was pumped through a $182-\mathrm{m}-\left(600^{+}-\mathrm{ft}-\right)$ long water line from well $399-1-7$, it was difficult to facilitate an instantaneous injection start), but may also be impacted by the effects of well bore storage. Another limitation in the data sets was in the duration of the constant rate injection test. Although running the test for a longer duration may have provided for a more definitive analysis, the tracer test did last long enough to get past the delayed yield portion of the curve and approach radial flow conditions.

Two other well locations within the targeted treatment zone (wells 399-1-29 and 399-1-31) showed a delayed pressure buildup response. The response and type curve match for well 399-1-31 is shown in Figure 6.26. The reason for the delayed pressure response at these locations is unknown, but it is most likely associated with formational heterogeneities not accounted for in the analytical technique used to analyze the response data.

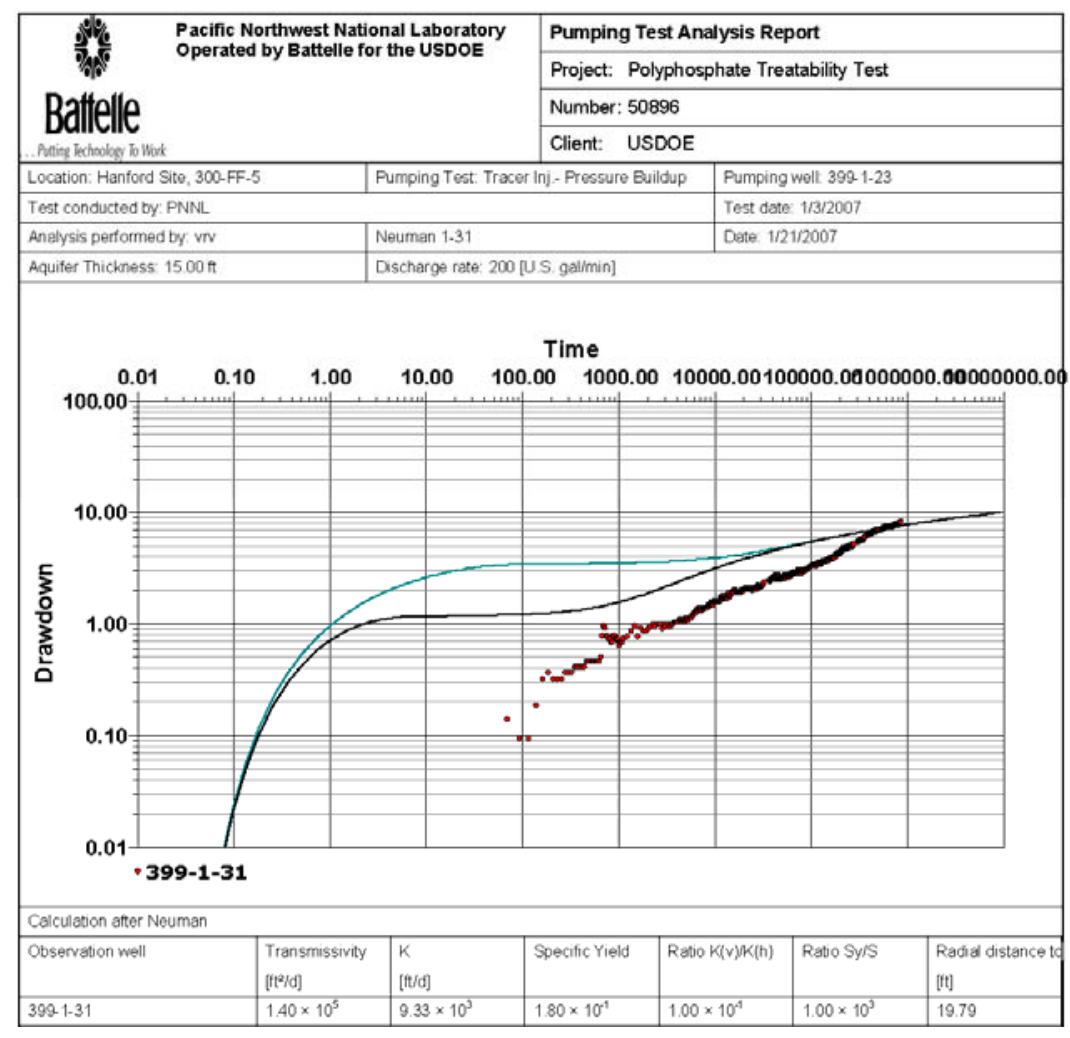

Figure 6.26. Neuman Type-Curve Analysis of Pressure Buildup Data at Well 399-1-31 
In addition to analysis of the pressure buildup data during the tracer injection test, a series of slug tests were conducted prior to the tracer injection in an attempt to obtain additional hydraulic property data. Slug tests were conducted in wells 399-1-23, 399-1-25, 399-1-26, 399-1-27, and 399-1-30 on December 8, 2006. The objective of these slug tests was to get a preliminary estimate of hydraulic conductivity and also get information on the variability of hydraulic conductivity at different wells located within a radius of 30 feet from the injection well. However, because of the high hydraulic conductivity of the aquifer and the small diameter of the wells, slug test responses were very rapid and of very small magnitude. This resulted an inability to obtain accurate estimates of $\mathrm{K}$ from the test analyses.

Slug tests were conducted by lowering a solid slugging rod into the water column within the well, allowing the water level to stabilize, and then rapidly removing the slugging rod causing a rapid reduction in the hydraulic head within the well. However, because the water level recovered so quickly, the slug test responses were affected by the small amount of time ( 1 to 2 seconds) required to remove the slugging rod. Instantaneous change of the water level in the well is one of the assumptions of slug test analysis techniques.

The slugging rod used at the larger 20.3-cm (8-in.) diameter well (399-1-23) measured 0.109-m $(0.36-\mathrm{ft})$ diameter and had a total length of $2.02 \mathrm{~m}(6.65 \mathrm{ft})$, with the ends being tapered over a length of $0.09 \mathrm{~m}(0.3 \mathrm{ft})$. The volume of the slugging rod was calculated at $0.017 \mathrm{~m}^{3}\left(0.61 \mathrm{ft}^{3}\right)$. For the remaining 10 -cm- (4-in.-) diameter wells a similar length tapered slugging rod with diameter $0.051 \mathrm{~m}(0.167 \mathrm{ft})$ and calculated volume of $0.0088 \mathrm{~m}^{3}\left(0.31 \mathrm{ft}^{3}\right)$ was employed. Slug withdrawal tests were used rather than slug injection tests because of reported better results for wells that are screened across the top of an unconfined aquifer (Bouwer 1989).

Water levels within the well were monitored by a pressure transducer placed below the lowest setting of the slugging rod. Some tests were conducted with the pressure transducer attached below the bottom of the slugging rod. For these tests, when the slugging rod was removed from the water the pressure transducer was still in the water but near the top of the water column. Having the transducer near the top of the water column provides a more accurate record of the very rapid water level changes (Zurcuchen 2002).

Three of the tested wells (399-1-23, 399-1-26 and 399-1-30) were completed over the entire Hanford formation thickness. An example of the water level response from one test in each of these wells is shown in Figure 6.27. Only about 5\% of the slugging rod induced displacement of the water level was observable in these wells after the rod was removed. The difference in observed response for well 399-1-23, which showed a transitional under-damped response (pressure oscillation), was caused by the larger casing and slugging rod volume. Attempts to quantitatively analyze the test responses were inconclusive because of the very rapid water level responses and affects of slugging rod removal. The other two tested wells (399-1-25 and 399-1-27) were completed in the lower portion of the Hanford formation and showed slower under-damped slug responses indicating qualitatively lower hydraulic conductivity in the deeper Hanford formation. However, quantitative results could not be obtained for these wells because of the effects of overlying high conductivity sediments.

\subsubsection{Hydraulic Gradient Analysis}

Another analysis approach that can provide useful information with respect to the spatial distribution of aquifer transmissivity is the evaluation of hydraulic gradients. Areas with higher hydraulic gradient are 
indicative of less permeable regions of the aquifer whereas areas with lower hydraulic gradients indicate more transmissive materials. This information, taken in concert with available hydrogeologic information (i.e., geologic structure, aquifer thickness) can be used to provide insights into the spatial distribution of horizontal hydraulic conductivity for an aquifer. Based on hydraulic gradient measurements made using polyphosphate treatability test site and surrounding monitoring wells, there is indication that aquifer transmissivity decreases as you move southeast from injection well 399-1-23 toward well 399-1-7. Water-level data collected for the injection and monitoring wells over several months following the tracer injection test indicate that the water table in the vicinity of the polyphosphate treatability test site has a relatively small gradient (Figure 6.28), as would be expected for such a high permeability formation.

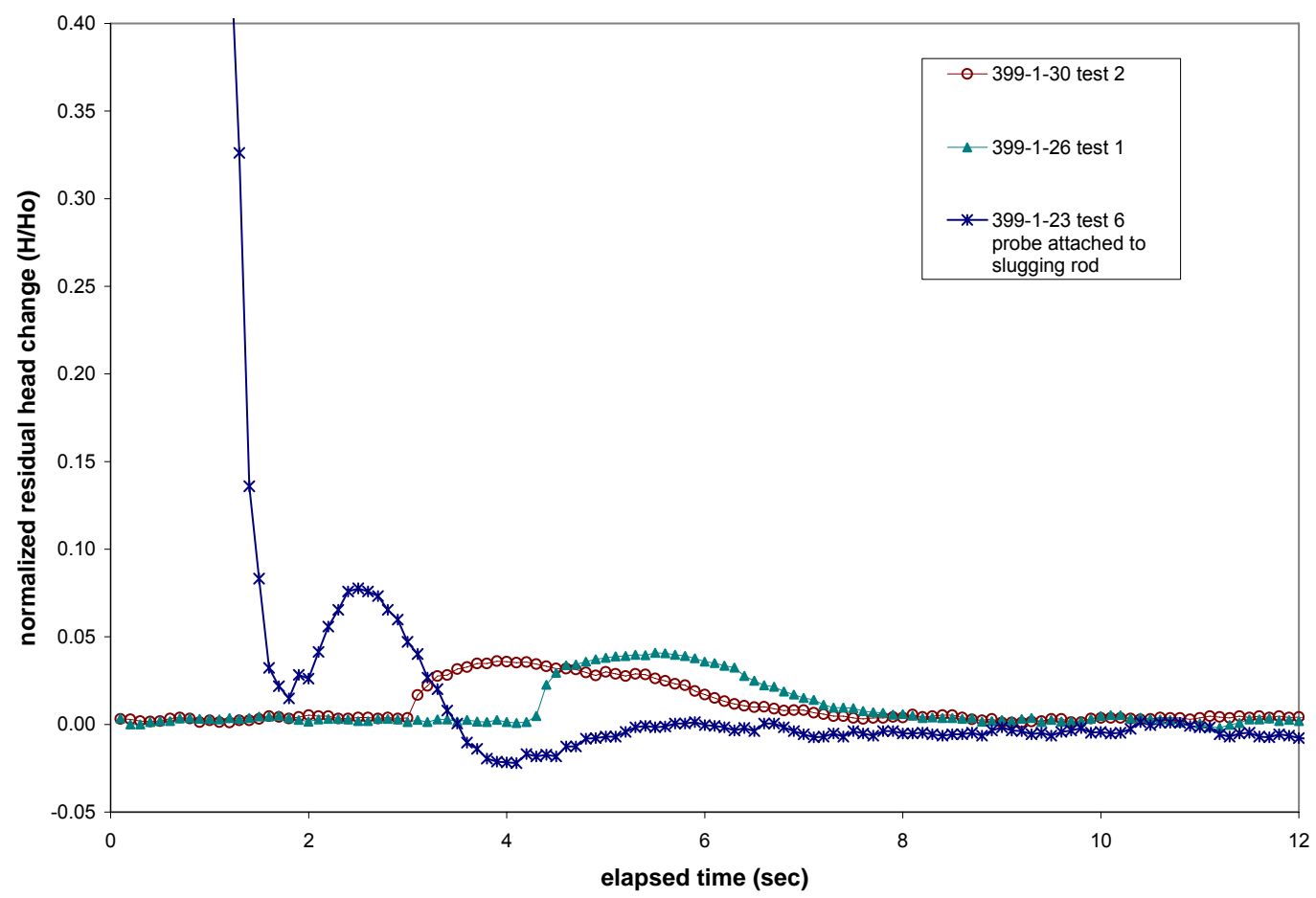

Figure 6.27. Example Slug Test Responses at Three Wells Completed Over the Entire Hanford Formation Thickness (stress level calculated from slug rod volume)

Figure 6.28 shows the calculated hydraulic gradients for three well pairs which have distinctly different gradients over this period. Inter-well gradients range from as high as 3.7E-3 near the test site injection well to as low as $1.5 \mathrm{E}-4 \mathrm{ft} / \mathrm{ft}$ over the most distal segment monitored during a period of relatively stable river stage conditions in February 2007. This observation is consistent with results from tracer injection test which suggest a more transmissive aquifer at greater distances from the injection well, as evidenced by the higher $\mathrm{K}$ estimate based on tracer drift between the injection well and downgradient monitoring well 399-1-32 ( 4,267 m [14,000 ft] per day) and the near-field K estimate of $\sim 2,743 \mathrm{~m}$ $(9,000 \mathrm{ft})$ per day based on results from the hydraulic test analysis (see discussion in Section 6.3).

\subsubsection{Additional Site Characterization Activities}

As discussed in Section 6.1, additional downgradient wells will be installed at the polyphosphate treatability test site in May 2007. During this drilling campaign, drill cuttings removed from the core 
barrel will be used to develop a geologic description of the subsurface materials. The borehole logs for these six new wells will be evaluated to determine the stratigraphic contacts and key lithologic changes where possible. In addition, if installation and development of these new wells is completed soon enough to allow for additional hydraulic testing at the site, without adversely impacting the schedule for conducting the polyphosphate injection test, electromagnetic borehole flowmeter testing will be conducted in the injection well and selected site monitoring wells. Electromagnetic borehole flowmeter testing is a method for assessing the vertical distribution of horizontal hydraulic conductivity (i.e., vertical heterogeneities) across a fully screened aquifer unit. By evaluating the spatial distribution of these data, conceptual models of site heterogeneity can be developed that incorporate the distribution, continuity, and lateral extent of high and low permeability features/intervals.

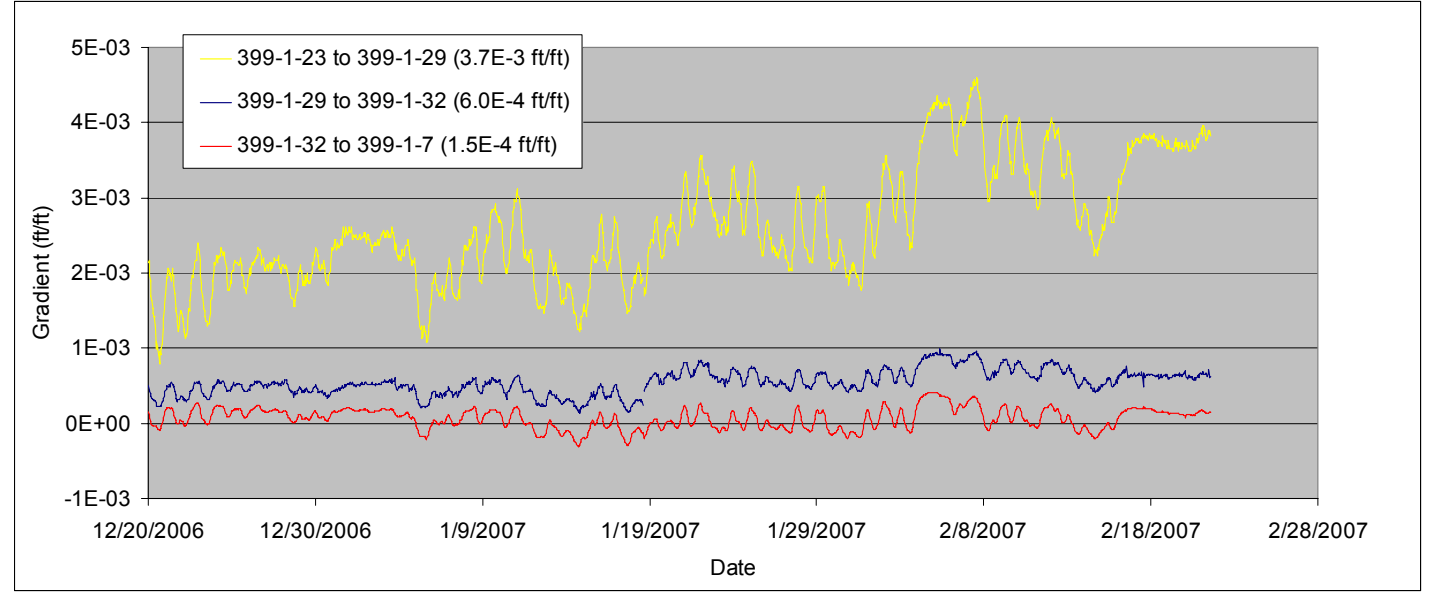

Figure 6.28. Post-Tracer Test Background Water-Level Gradients for Well-Well Combinations Stepping Progressively Down Gradient. Average gradients during a period of stable river stage in the middle part of February 2007 are shown in parentheses.

\subsection{Baseline Groundwater Monitoring}

Three baseline sampling activities are planned prior to injection. The first baseline sampling event occurred prior to the tracer injection on December 13, 2006; the second event occurred on April 23, 2007, approximately 2 months prior to injection. Analytic data from the second sampling event was not available in time for inclusion in this TTP. The third baseline sampling event will occur immediately prior to injection. Results of the first baseline sampling event (Tables 6.7 through 6.10) indicate relatively uniform analyte concentrations in the vicinity of well 399-1-23. During the first baseline sampling event, there were two wells where concentrations were not consistent with concentrations measured in other wells. Uranium concentration in 399-1-26, which is located on the upgradient side of the targeted treatment zone to the northwest of 399-1-23 (Figure 6.1), was lower relative to other wells in the network. This result is consistent with local-scale uranium plume maps (Figure 1.2) that show the test site location near the western edge of the plume. The other well of interest during the first baseline sampling event was 399-1-27. This well is thought to be completed in a low permeability zone based on this well's tracer test results and hydraulic response. The concentrations of uranium, molybdenum, fluoride and sulfate were all elevated relative to the other monitoring wells. This is consistent with the higher specific conductance and lower dissolved oxygen measured in 399-1-27 at the time of sample 
Table 6.7. Anion Concentration Results from the First Baseline Sampling Event (December 2006)

\begin{tabular}{|c|c|c|c|c|c|c|c|c|c|}
\hline Well Name & $\begin{array}{c}\text { Fluoride } \\
\mu \mathrm{g} / \mathrm{mL}\end{array}$ & $\begin{array}{c}\text { Formate } \\
\mu \mathrm{g} / \mathrm{mL}\end{array}$ & $\begin{array}{c}\text { Chloride } \\
\mu \mathrm{g} / \mathrm{mL}\end{array}$ & $\begin{array}{c}\text { Nitrite } \\
\mu \mathrm{g} / \mathrm{mL}\end{array}$ & $\begin{array}{c}\text { Bromide } \\
\mu \mathrm{g} / \mathrm{mL}\end{array}$ & $\begin{array}{c}\text { Nitrate } \\
\mu \mathrm{g} / \mathrm{mL}\end{array}$ & $\begin{array}{c}\text { Carbonate } \\
\mu \mathrm{g} / \mathrm{mL}\end{array}$ & $\begin{array}{c}\text { Sulfate } \\
\mu \mathrm{g} / \mathrm{mL}\end{array}$ & $\begin{array}{c}\text { Phosphate } \\
\mu \mathrm{g} / \mathrm{mL}\end{array}$ \\
\hline $399-1-23$ & 0.25 & $<1.00$ & 20.39 & $<1.00$ & $<1.00$ & 24.65 & 113.80 & 59.31 & $<1.50$ \\
\hline $399-1-24$ & 0.25 & $<1.00$ & 19.61 & $<1.00$ & $<1.00$ & 24.33 & 111.45 & 59.25 & $<1.50$ \\
\hline $399-1-27$ & 0.29 & $<1.00$ & 19.90 & $<1.00$ & $<1.00$ & 23.45 & 112.32 & 86.06 & $<1.50$ \\
\hline $399-1-25$ & 0.25 & $<1.00$ & 19.42 & $<1.00$ & $<1.00$ & 24.02 & 112.22 & 59.03 & $<1.50$ \\
\hline $399-1-30$ & 0.25 & $<1.00$ & 19.08 & $<1.00$ & $<1.00$ & 23.67 & 114.85 & 59.06 & $<1.50$ \\
\hline $399-1-31$ & 0.25 & $<1.00$ & 19.64 & $<1.00$ & $<1.00$ & 24.06 & 113.87 & 59.15 & $<1.50$ \\
\hline $399-1-26$ & 0.25 & $<1.00$ & 19.74 & $<1.00$ & $<1.00$ & 23.71 & 111.08 & 58.96 & $<1.50$ \\
\hline $399-1-28$ & 0.24 & $<1.00$ & 19.91 & $<1.00$ & $<1.00$ & 24.14 & 112.25 & 58.40 & $<1.50$ \\
\hline $399-1-29$ & 0.25 & $<1.00$ & 19.52 & $<1.00$ & $<1.00$ & 24.28 & 108.45 & 58.63 & $<1.50$ \\
\hline $399-1-32$ & 0.25 & $<1.00$ & 19.68 & $<1.00$ & $<1.00$ & 24.23 & 112.00 & 59.68 & $<1.50$ \\
\hline Average & 0.25 & NA & 19.69 & NA & NA & 24.05 & 112.23 & 61.75 & NA \\
\hline Standard Deviation & 0.01 & NA & 0.34 & NA & NA & 0.36 & 1.77 & 8.55 & NA \\
\hline
\end{tabular}

Table 6.8. Trace Metals Concentration Results by from the first Baseline Sampling Event (December 2006). Parentheses indicate reported result was less that quantification limit. Less than symbol indicates that result was less than detection limit.

\begin{tabular}{|c|c|c|c|c|c|c|c|c|c|c|}
\hline Well I & $\begin{array}{l}\text { Uranium } \\
\mu \mathrm{g} / \mathrm{L}\end{array}$ & $\begin{array}{l}\mathrm{Cr} 52 \\
\mu \mathrm{g} / \mathrm{L}\end{array}$ & $\begin{array}{l}\mathrm{Cr} 53 \\
\mu \mathrm{g} / \mathrm{L}\end{array}$ & $\begin{array}{c}\text { Cu } 63 \\
\mu \mathrm{g} / \mathrm{L}\end{array}$ & $\begin{array}{c}\mathrm{Cu} 65 \\
\mu \mathrm{g} / \mathrm{L}\end{array}$ & $\begin{array}{c}\text { As } 75 \\
\mu g / L\end{array}$ & $\begin{array}{c}\text { Se } 82 \\
\mu \mathrm{g} / \mathrm{L}\end{array}$ & $\begin{array}{c}\text { Mo } 95 \\
\mu \mathrm{g} / \mathrm{L}\end{array}$ & $\begin{array}{c}\text { Mo } 97 \\
\mu \mathrm{g} / \mathrm{L}\end{array}$ & $\begin{array}{c}\text { Mo } 98 \\
\mu \mathrm{g} / \mathrm{L}\end{array}$ \\
\hline $399-1-23$ & 60.60 & $(4.11 \mathrm{E}+00)$ & $4.45 \mathrm{E}+00$ & $5.28 \mathrm{E}+00$ & $5.39 \mathrm{E}+00$ & $2.88 \mathrm{E}+00$ & $4.69 \mathrm{E}+00$ & $5.00 \mathrm{E}+00$ & $5.14 \mathrm{E}+00$ & \begin{tabular}{|l|l}
$5.07 \mathrm{E}+00$ \\
\end{tabular} \\
\hline $399-1-24$ & 60.76 & $(4.01 \mathrm{E}+00)$ & $4.48 \mathrm{E}+00$ & $8.01 \mathrm{E}+00$ & $8.04 \mathrm{E}+00$ & $2.62 \mathrm{E}+00$ & $4.93 \mathrm{E}+00$ & $5.24 \mathrm{E}+00$ & $5.39 \mathrm{E}+00$ & $5.43 \mathrm{E}+00$ \\
\hline $399-1-27$ & 75.10 & $(3.03 E+00)$ & $3.36 \mathrm{E}+00$ & $6.15 \mathrm{E}+00$ & $5.98 \mathrm{E}+00$ & $2.77 \mathrm{E}+00$ & $5.42 \mathrm{E}+00$ & $1.73 \mathrm{E}+01$ & $1.76 \mathrm{E}+01$ & $1.77 \mathrm{E}+01$ \\
\hline $399-1-25$ & 3.61 & $(4.09 \mathrm{E}+00)$ & $4.47 \mathrm{E}+00$ & $(4.14 \mathrm{E}+00)$ & $(4.10 \mathrm{E}+00)$ & $2.88 \mathrm{E}+00$ & $5.06 \mathrm{E}+00$ & \begin{tabular}{|l|}
$5.66 \mathrm{E}+00$ \\
\end{tabular} & $5.69 \mathrm{E}+00$ & $5.77 \mathrm{E}+00$ \\
\hline $399-1-30$ & .61 & $(4.36 \mathrm{E}+00)$ & $4.72 \mathrm{E}+00$ & $1.02 \mathrm{E}+01$ & $1.03 \mathrm{E}+01$ & $3.15 \mathrm{E}+00$ & $5.38 \mathrm{E}+00$ & $5.17 \mathrm{E}+00$ & $5.16 \mathrm{E}+00$ & \begin{tabular}{|l|}
$5.19 \mathrm{E}+00$ \\
\end{tabular} \\
\hline $399-1-31$ & 60.46 & $(4.47 \mathrm{E}+00)$ & $5.00 \mathrm{E}+00$ & \begin{tabular}{|l|}
$7.16 \mathrm{E}+00$ \\
\end{tabular} & $7.13 \mathrm{E}+00$ & $3.31 \mathrm{E}+00$ & $4.70 \mathrm{E}+00$ & \begin{tabular}{|c|}
$5.17 \mathrm{E}+00$ \\
\end{tabular} & $5.11 \mathrm{E}+00$ & $5.16 \mathrm{E}+00$ \\
\hline $399-1-26$ & 47.49 & $(4.61 \mathrm{E}+00)$ & $5.08 \mathrm{E}+00$ & $1.57 \mathrm{E}+01$ & $1.57 \mathrm{E}+01$ & $3.34 \mathrm{E}+00$ & $5.06 \mathrm{E}+00$ & $5.18 \mathrm{E}+00$ & $5.39 \mathrm{E}+00$ & $5.33 \mathrm{E}+00$ \\
\hline $399-1-28$ & & $(3.67$ & $4.16 \mathrm{E}+00$ & $(4.37 \mathrm{E}+00)$ & $(4.39 \mathrm{E}+00)$ & $2.31 \mathrm{E}+00$ & $4.84 \mathrm{E}+00$ & $E+00$ & +00 & $E+00$ \\
\hline $399-1-29$ & 56 & $(3.93$ & $4.39 \mathrm{E}+00$ & $(4.58 \mathrm{E}+00)$ & $(4.59 \mathrm{E}+00)$ & $2.98 \mathrm{E}+00$ & $4.87 \mathrm{E}+00$ & $E+00$ & $E+00$ & $5.30 \mathrm{E}+00$ \\
\hline $399-1-32$ & 57.06 & $(3.90 \mathrm{E}+00)$ & $4.37 \mathrm{E}+00$ & $6.91 \mathrm{E}+00$ & $6.98 \mathrm{E}+00$ & $2.84 \mathrm{E}+00$ & $5.05 \mathrm{E}+00$ & \begin{tabular}{|l|l|}
$5.48 \mathrm{E}+00$ \\
\end{tabular} & $5.51 \mathrm{E}+00$ & $5.67 \mathrm{E}+00$ \\
\hline Average & 60.28 & $(4.02 E+00)$ & $4.45 \mathrm{E}+00$ & $7.25 \mathrm{E}+00$ & $7.26 \mathrm{E}+00$ & $2.91 \mathrm{E}+00$ & $5.00 \mathrm{E}+00$ & $6.43 \mathrm{E}+00$ & $6.54 \mathrm{E}+00$ & $6.56 \mathrm{E}+00$ \\
\hline Standard Deviation & .36 & 4.4 & -01 & $3.50 \mathrm{E}+00$ & +00 & $3 \mathrm{E}-01$ & -01 & $=+00$ & $E+00$ & +00 \\
\hline Well Name & $\begin{array}{c}\mathrm{Ru} 101 \\
\mu \mathrm{g} / \mathrm{L}\end{array}$ & $\begin{array}{c}\mathrm{Ru} 102 \\
\mu \mathrm{g} / \mathrm{L}\end{array}$ & $\begin{array}{c}\mathrm{Ag} 107 \\
\mu \mathrm{g} / \mathrm{L}\end{array}$ & $\begin{array}{c}\mathrm{Ag} 109 \\
\mu \mathrm{g} / \mathrm{L}\end{array}$ & $\begin{array}{c}\text { Cd } 111 \\
\mu \mathrm{g} / \mathrm{L}\end{array}$ & $\begin{array}{c}\text { Cd } 114 \\
\mu \mathrm{g} / \mathrm{L}\end{array}$ & $\begin{array}{c}\mathrm{Sb} 121 \\
\mu \mathrm{g} / \mathrm{L}\end{array}$ & $\begin{array}{c}\text { Sb } 123 \\
\mu \mathrm{g} / \mathrm{L}\end{array}$ & $\begin{array}{c}\mathrm{Pb} 206 \\
\mu \mathrm{g} / \mathrm{L}\end{array}$ & $\begin{array}{c}\mathrm{Pb} 208 \\
\mu \mathrm{g} / \mathrm{L}\end{array}$ \\
\hline $399-1-23$ & $<1.25 \mathrm{E}+00$ & \begin{tabular}{|c|c|}
$(2.45 \mathrm{E}-02)$ \\
\end{tabular} & $(3.02 \mathrm{E}-02)$ & \begin{tabular}{|l|}
$(1.05 \mathrm{E}-03)$ \\
\end{tabular} & $(5.05 \mathrm{E}-02)$ & $(5.26 \mathrm{E}-02)$ & $(2.62 \mathrm{E}-01)$ & \begin{tabular}{|l|}
$(2.46 \mathrm{E}-01)$ \\
\end{tabular} & $(1.77 \mathrm{E}-01)$ & $(1.72 \mathrm{E}-01)$ \\
\hline $399-1-24$ & $<1.25 \mathrm{E}+00$ & \begin{tabular}{|l|}
$(1.72 \mathrm{E}-02)$ \\
\end{tabular} & (1.54E-02) & $<1.25 \mathrm{E}+00$ & \begin{tabular}{|l}
$(5.26 \mathrm{E}-02)$ \\
\end{tabular} & $(5.84 \mathrm{E}-02)$ & E-01) & E-01) & $(1.50 \mathrm{E}-01)$ & (1.42E-01) \\
\hline $399-1-27$ & $1.25 \mathrm{E}+00$ & \begin{tabular}{|l|}
$(1.87 \mathrm{E}-02)$ \\
\end{tabular} & $(1.30 \mathrm{E}-02)$ & $<1.2$ & \begin{tabular}{|l|} 
(7.07E-02) \\
\end{tabular} & $(7.10 \mathrm{E}-02)$ & -01) & E-01) & $(2.95 \mathrm{E}-01)$ & \begin{tabular}{|l|}
$(2.66 \mathrm{E}-01)$ \\
\end{tabular} \\
\hline $399-1-25$ & $<1.25 \mathrm{E}+00$ & \begin{tabular}{|l|} 
(7.37E-03) \\
\end{tabular} & $(1.22 \mathrm{E}-02)$ & $<1.25 \mathrm{E}+00$ & \begin{tabular}{|l|}
$(3.81 \mathrm{E}-02)$ \\
\end{tabular} & $(4.47 \mathrm{E}-02)$ & \begin{tabular}{|l|}
$(2.62 \mathrm{E}-01)$ \\
\end{tabular} & \begin{tabular}{|l}
$(2.59 \mathrm{E}-01)$ \\
\end{tabular} & $(2.35 \mathrm{E}-01)$ & \begin{tabular}{|l}
$(2.24 \mathrm{E}-01)$ \\
\end{tabular} \\
\hline $399-1-30$ & $<1.25 \mathrm{E}+00$ & \begin{tabular}{|l|}
$(1.76 \mathrm{E}-02)$ \\
\end{tabular} & $(1.04 \mathrm{E}-02)$ & $<1.25 \mathrm{E}+00$ & \begin{tabular}{|l|}
$(1.89 \mathrm{E}-02)$ \\
\end{tabular} & $(3.27 \mathrm{E}-02)$ & $(2.22)$ & \begin{tabular}{|l}
$(1.81 \mathrm{E}-01)$ \\
\end{tabular} & $(1.17 \mathrm{E}-01)$ & \begin{tabular}{|l|}
$(1.14 \mathrm{E}-01)$ \\
\end{tabular} \\
\hline 399-1-31 & $1.25 \mathrm{E}+00$ & \begin{tabular}{|l|}
$(1.76 \mathrm{E}-02)$ \\
\end{tabular} & $(7.64 \mathrm{E}-03)$ & $<1.25 \mathrm{E}+00$ & \begin{tabular}{|l|l}
$(2.64 \mathrm{E}-02)$ \\
\end{tabular} & $(3.32 \mathrm{E}-02)$ & \begin{tabular}{|l|}
$(1.99 \mathrm{E}-01)$ \\
\end{tabular} & \begin{tabular}{|l|}
$(1.80 \mathrm{E}-01)$ \\
\end{tabular} & $(3.98 \mathrm{E}-01)$ & \begin{tabular}{|c|}
$(3.67 \mathrm{E}-01)$ \\
\end{tabular} \\
\hline $399-1-26$ & $<1.25 \mathrm{E}+00$ & \begin{tabular}{|l}
$(1.29 \mathrm{E}-02)$ \\
\end{tabular} & $(1.12 \mathrm{E}-02)$ & $<1.25 \mathrm{E}+00$ & \begin{tabular}{|l} 
(2.43E-02) \\
\end{tabular} & $(3.64 \mathrm{E}-02)$ & (1.94E-01) & \begin{tabular}{|l}
$(1.91 \mathrm{E}-01)$ \\
\end{tabular} & $(2.65 \mathrm{E}-01)$ & \begin{tabular}{|l|}
$(2.56 \mathrm{E}-01)$ \\
\end{tabular} \\
\hline $399-1-28$ & $<1.25 \mathrm{E}+00$ & \begin{tabular}{|l|}
$(1.51 \mathrm{E}-02)$ \\
\end{tabular} & $(9.65 \mathrm{E}-03)$ & $<1.25 \mathrm{E}+00$ & \begin{tabular}{|c|}
$(3.26 \mathrm{E}-02)$ \\
\end{tabular} & $(4.27 \mathrm{E}-02)$ & \begin{tabular}{|c|}
$(2.17 \mathrm{E}-01)$ \\
\end{tabular} & \begin{tabular}{|l|}
$(2.08 \mathrm{E}-01)$ \\
\end{tabular} & $(1.60 \mathrm{E}-01)$ & \begin{tabular}{|l}
$(1.41 \mathrm{E}-01)$ \\
\end{tabular} \\
\hline $399-1-29$ & $<1.25 \mathrm{E}+00$ & \begin{tabular}{|l}
$(1.27 \mathrm{E}-02)$ \\
\end{tabular} & $(6.48 \mathrm{E}-03)$ & $<1.25 \mathrm{E}+00$ & \begin{tabular}{|l}
$(2.63 \mathrm{E}-02)$ \\
\end{tabular} & $(3.68 \mathrm{E}-02)$ & $(2.0$ & E-01) & (8.37E-02) & $(7.16 \mathrm{E}-02)$ \\
\hline $399-1-32$ & $<1.25 \mathrm{E}+00$ & \begin{tabular}{|l} 
(8.54E-03) \\
\end{tabular} & (5.15E-03) & $<1.25 \mathrm{E}+00$ & (3.17E-02) & $(4.48 \mathrm{E}-02)$ & \begin{tabular}{|l|}
$(2.16 \mathrm{E}-01)$ \\
\end{tabular} & \begin{tabular}{|l|}
$(2.12 \mathrm{E}-01)$ \\
\end{tabular} & $(1.26 \mathrm{E}-01)$ & $(1.16 \mathrm{E}-01)$ \\
\hline Average & $\mathrm{NA}$ & $(1.52 \mathrm{E}-02)$ & $(1.21 \mathrm{E}-02)$ & $<1.25 \mathrm{E}+00$ & (3.72E-02) & $(4.53 \mathrm{E}-02)$ & $(2.42 \mathrm{E}-01)$ & $(2.29 \mathrm{E}-01)$ & $(2.01 \mathrm{E}-01)$ & (1.87E-01) \\
\hline Standard Deviation & NA & $5.07 \mathrm{E}-03$ & $7.05 \mathrm{E}-03$ & \begin{tabular}{|l|}
$3.95 \mathrm{E}-01$ \\
\end{tabular} & $1.61 \mathrm{E}-02$ & $1.22 \mathrm{E}-02$ & $5.25 \mathrm{E}-02$ & $5.51 \mathrm{E}-02$ & $9.67 \mathrm{E}-02$ & $9.01 \mathrm{E}-02$ \\
\hline
\end{tabular}


Table 6.9. Cation Concentration Results from the first Baseline Sampling Event (December 2006). Parentheses indicate reported result was less that quantification limit. Less than symbol indicates that result was less than detection limit.

\begin{tabular}{|c|c|c|c|c|c|c|c|c|c|c|c|}
\hline ne & $\begin{array}{c}\mathrm{Al} \\
\mu \mathrm{g} / \mathrm{L}\end{array}$ & $\begin{array}{c}\text { As } \\
\mu \mathrm{g} / \mathrm{L}\end{array}$ & $\begin{array}{c}\mathrm{B} \\
\mu \mathrm{g} / \mathrm{L}\end{array}$ & $\begin{array}{c}\mathrm{Ba} \\
\mu \mathrm{g} / \mathrm{L}\end{array}$ & $\begin{array}{c}\mathrm{Be} \\
\mu \mathrm{g} / \mathrm{L}\end{array}$ & $\begin{array}{r}\mathrm{Bi} \\
\mu \mathrm{g} / \mathrm{L}\end{array}$ & $\begin{array}{c}\mathrm{Ca} \\
\mu \mathrm{g} / \mathrm{L}\end{array}$ & $\begin{array}{c}\mathrm{Cd} \\
\mu \mathrm{g} / \mathrm{L}\end{array}$ & $\begin{array}{r}\text { Co } \\
\mu \mathrm{g} / \mathrm{L}\end{array}$ & $\begin{array}{c}\mathrm{Cr} \\
\mu \mathrm{g} / \mathrm{L}\end{array}$ & $\begin{array}{c}\mathrm{Cu} \\
\mu \mathrm{g} / \mathrm{L}\end{array}$ \\
\hline $399-1-23$ & $.25 \mathrm{E}+02$ & $(2.18 \mathrm{E}+01)$ & $.12 \mathrm{E}+01)$ & $5.83 \mathrm{E}+01)$ & $(9.12 \mathrm{E}-01)$ & $(1.65 \mathrm{E}+01)$ & $5.18 \mathrm{E}+04$ & $(9.63 \mathrm{E}-01)$ & $(1.14 \mathrm{E}+00)$ & $(3.33 \mathrm{E}+00$ & $6.52 \mathrm{E}+01)$ \\
\hline & $.25 \mathrm{E}+02$ & \begin{tabular}{|l|l}
$(6.12 \mathrm{E}-01$ \\
\end{tabular} & $<2.50 \mathrm{E}+03$ & $(5.22 \mathrm{E}+01)$ & $<2.50 \mathrm{E}+01$ & $(5.00 \mathrm{E}+01)$ & $5.02 \mathrm{E}+04$ & $<6.25 \mathrm{E}+01$ & $(1.66 \mathrm{E}+00)$ & $(2.73 \mathrm{E}+00$ & $6.35 \mathrm{E}+01)$ \\
\hline & & & & & & 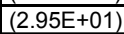 & & & & & \\
\hline & $.25 \mathrm{E}+02$ & $(9.04 E+01)$ & $<2.50 \mathrm{E}+03$ & $(5.80 \mathrm{E}+01)$ & $6.85 \mathrm{E}-0$ & $(1.14 \mathrm{E}+01)$ & $14 \mathrm{E}+04$ & $3.50 \mathrm{E}-01)$ & $<6.25 \mathrm{E}+01$ & $33 \mathrm{E}+00$ & $5.06 \mathrm{E}+01)$ \\
\hline & & & & & & 1) & & & & & \\
\hline 399 & $.25 \mathrm{E}+02$ & $<5.00 \mathrm{E}+02$ & $<2.50 \mathrm{E}+03$ & $(5.88 \mathrm{E}+01)$ & $<2.50 \mathrm{E}+01$ & $(8.14 \mathrm{E}+00)$ & $5.13 \mathrm{E}+04$ & $<6.25 \mathrm{E}+01$ & \begin{tabular}{|l|}
$(5.02 \mathrm{E}-01)$ \\
\end{tabular} & (3.34E & $(4.90 \mathrm{E}+01)$ \\
\hline & $25 \mathrm{E}+02$ & $<5.00$ & $35 \mathrm{E}+00)$ & $56 \mathrm{E}+01)$ & $.50 \mathrm{E}+01$ & $(2.79 \mathrm{E}+01)$ & $\mathrm{DE}+04$ & $2.04 \mathrm{E}+00)$ & $(4.04 \mathrm{E}$ & (3.13 & $(5.53 \mathrm{E}+01)$ \\
\hline $39 c$ & $.25 \mathrm{E}+02$ & $(3.14 \mathrm{E}+01)$ & $(2.90 \mathrm{E}+02)$ & $5.71 \mathrm{E}+01)$ & $2.50 \mathrm{E}+01$ & $(2.07 \mathrm{E}+01)$ & $5.22 E+04$ & \begin{tabular}{|l}
$(7.36 \mathrm{E}-01)$ \\
\end{tabular} & $(2.47 \mathrm{E}+00)$ & $(1.75 E+00)$ & $(5.59 \mathrm{E}+01)$ \\
\hline & $.25 \mathrm{E}+02$ & $(5.21 \mathrm{E}+01)$ & $(4.22 \mathrm{E}+02)$ & $(5.65 \mathrm{E}+01)$ & $(6.08 \mathrm{E}-03)$ & $<2.50 \mathrm{E}+03$ & $5.15 \mathrm{E}+04$ & $1.06 \mathrm{E}+00)$ & $<6.25 \mathrm{E}$ & $(2.62 \mathrm{E}+00$ & $(4.70 \mathrm{E}+01)$ \\
\hline & $.25 \mathrm{E}+02$ & $(1.86 \mathrm{E}+01)$ & $(3.93 \mathrm{E}+02)$ & $(6.06 \mathrm{E}+01)$ & $<2.50 \mathrm{E}+01$ & $(2.54 \mathrm{E}+01)$ & $5.11 \mathrm{E}+04$ & $\begin{array}{l}(4.14 \mathrm{E}-01) \\
\end{array}$ & (6.30E & & $(4.2$ \\
\hline & $\overline{\mathrm{NA}}$ & $1.30 \mathrm{E}+02$ & $1.36 \mathrm{E}+03$ & $5.73 \mathrm{E}+01$ & $1.27 \mathrm{E}+01$ & $2.71 \mathrm{E}+02$ & $5.12 E+04$ & $1.94 \mathrm{E}+01$ & $1.95 \mathrm{E}+01$ & $3.01 \mathrm{E}+0 \mathrm{C}$ & $5.37 \mathrm{E}+01$ \\
\hline t & $\mathrm{N}$ & $1.97 \mathrm{E}+02$ & $\mathrm{NA}$ & $2.30 \mathrm{E}$ & NA & $7.83 E+02$ & 6.4 & 2.98 & 2.9 & 5 & 7.13 \\
\hline Well Name & $\begin{array}{c}\mathrm{Fe} \\
\mu \mathrm{g} / \mathrm{L}\end{array}$ & $\mathrm{K}$ & $\mathrm{Li}$ & $\mathrm{Mg}$ & $\mathrm{Mn}$ & Mo & $\mathrm{Ni}$ & $\begin{array}{r}\mathrm{P} \\
\mu \mathrm{g} / \mathrm{L}\end{array}$ & $\mathrm{Pb}$ & $\begin{array}{c}\mathrm{Se} \\
\mu \mathrm{g} / \mathrm{L}\end{array}$ & $\mathrm{Sr}$ \\
\hline $399-1-23$ & $(9.91 \mathrm{E}+00)$ & $(4.45 \mathrm{E}+03)$ & $(3.15 \mathrm{E}+01)$ & $1.20 \mathrm{E}+04$ & $<2.50 \mathrm{E}+01$ & $(7.72 \mathrm{E}+00)$ & \begin{tabular}{|l}
$(1.78 \mathrm{E}+01)$ \\
\end{tabular} & $(1.66 \mathrm{E}+02)$ & $<1.25 \mathrm{E}+02$ & \begin{tabular}{|c|}
$(4.97 \mathrm{E}+02)$ \\
\end{tabular} & $2.43 \mathrm{E}+02$ \\
\hline & $93 \mathrm{E}+00)$ & $(4.56 \mathrm{E}+03)$ & $(5.24 \mathrm{E}+01)$ & $1.22 \mathrm{E}+04$ & $2.64 \mathrm{E}+01$ & $.35 \mathrm{E}+00)$ & -01) & $.45 \mathrm{E}+02)$ & $1.25 \mathrm{E}+02$ & $1.25 \mathrm{E}+02)$ & $2.37 \mathrm{E}+02$ \\
\hline & $2 \mathrm{E}+$ & $(4.71 \mathrm{E}+03)$ & $82 \mathrm{E}+01)$ & $1.16 \mathrm{E}$ & 8.6 & $.09[+01)$ & 11) & $49 \mathrm{E}+02)$ & 1.25 & $5.11 \mathrm{E}+02)$ & $2.40 \mathrm{E}+02$ \\
\hline & $\overline{\Gamma-}$ & $(4.76 \mathrm{E}+03)$ & $10 \mathrm{E}+01)$ & $1.24 \mathrm{E}$ & $7.58 \mathrm{E}+01$ & $(5.22 \mathrm{E}+00)$ & $.99 \mathrm{E}+01)$ & $.75 E+02)$ & $1.25 \mathrm{E}+02$ & $(5.87 \mathrm{E}+02)$ & $2.42 \mathrm{E}+02$ \\
\hline & $24 \mathrm{E}+0$ & $(4.63 \mathrm{E}+03)$ & $83 \mathrm{E}+01)$ & 1.22 & 2.5 & $.50 \mathrm{E}+00)$ & 1) & $.76 \mathrm{E}+02)$ & 1.2 & $43 \mathrm{E}+02)$ & $2.41 \mathrm{E}+02$ \\
\hline & $24 \mathrm{E}+0$ & $(4.92 \mathrm{E}+03)$ & $20 \mathrm{E}+01)$ & 1.23 & $<2.50 \mathrm{E}+01$ & $(1.01 \mathrm{E}+01)$ & $.66 \mathrm{E}+01)$ & $.56 \mathrm{E}+02)$ & $-1.25 \mathrm{E}+02$ & $5.81 \mathrm{E}+02)$ & $2.39 \mathrm{E}+02$ \\
\hline & +0 & $(4.62 \mathrm{E}+03)$ & $21 \mathrm{E}+0$ & 1.2 & $2.50 \mathrm{E}+01$ & $<1.25 \mathrm{E}+02$ & 01) & $47 \mathrm{E}+02)$ & $1.25 \mathrm{E}+02$ & $68 \mathrm{E}+02)$ & $2.38 \mathrm{E}+02$ \\
\hline & $8+0$ & $(3.99 E+03)$ & $(4.3$ & & $(5.52 \mathrm{E}+00)$ & $<1.25 \mathrm{E}+02$ & 1) & $E+02)$ & 02 & 02) & $2.45 \mathrm{E}+02$ \\
\hline & & (4.57E+ & 123 & & $(4.16 \mathrm{E}+00)$ & $(6.90 \mathrm{E}+00)$ & & $E+02)$ & 125 & & 2.4 \\
\hline & $36 \mathrm{E}+01$ & $(4.59$ & $(3.02$ & $1.22 \mathrm{E}$ & 4.00 & $<1.25 \mathrm{E}+02$ & $(1.62$ & (1.7 & $<1.25 \mathrm{E}+02$ & $(4.39 \mathrm{E}+02)$ & $2.41 \mathrm{E}+02$ \\
\hline & 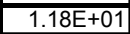 & $4.58 \mathrm{E}+03$ & $3.32 \mathrm{E}+01$ & & $\overline{E+01}$ & $4.46 \mathrm{E}+01$ & & 1. & $\overline{\mathrm{NA}}$ & $4.85 \mathrm{E}+02$ & $2.41 \mathrm{E}+02$ \\
\hline tandard Deviatic & $1.49 \mathrm{E}+01$ & $2.44 \mathrm{E}+02$ & $9.77 \mathrm{E}+00$ & $2.10 \mathrm{E}+02$ & $2.72 \mathrm{E}+01$ & $5.59 \mathrm{E}+01$ & $2.38 \mathrm{E}+00$ & $1.14 \mathrm{E}+01$ & $\mathrm{NA}$ & $8.31 \mathrm{E}+01$ & $2.29 \mathrm{E}+00$ \\
\hline ne & $\begin{array}{c}\mathrm{TI} \\
\mu \mathrm{g} / \mathrm{L}\end{array}$ & $\begin{array}{c}V \\
\mu \mathrm{g} / \mathrm{L}\end{array}$ & $\begin{array}{c}\mathrm{Zn} \\
\mu \mathrm{g} / \mathrm{L}\end{array}$ & $\mathrm{Na}$ & $\mathrm{Si}$ & $\begin{array}{c}\mathrm{S} \\
\mu \mathrm{g} / \mathrm{L}\end{array}$ & $\begin{array}{c}\mathrm{Ti} \\
\mu \mathrm{g} / \mathrm{L}\end{array}$ & $\begin{array}{c}\mathrm{Zr} \\
\mu \mathrm{g} / \mathrm{L}\end{array}$ & $\begin{array}{c}\mathrm{Ag} \\
\mu \mathrm{g} / \mathrm{L}\end{array}$ & $\begin{array}{c}\mathrm{Re} \\
\mu \mathrm{g} / \mathrm{L}\end{array}$ & $\begin{array}{c}\mathrm{Sb} \\
\mu \mathrm{g} / \mathrm{L}\end{array}$ \\
\hline & $8 \mathrm{E} \Omega$ & $<1.25 \mathrm{E}+02$ & $(8.28 \mathrm{E}+01)$ & $28 \mathrm{E}+04$ & $1.34 \mathrm{E}+04$ & $1.95 \mathrm{E}+04$ & $6.25 \mathrm{E}+01$ & $5.99 \mathrm{E}-01)$ & $1.16 \mathrm{E}+01)$ & $(2.09 \mathrm{E}+00)$ & $2.50 \mathrm{E}+02$ \\
\hline & $00 \mathrm{E}+\mathrm{C}$ & $(2.83 \mathrm{E}+00)$ & $(8.52 \mathrm{E}+01)$ & $.26 \mathrm{E}+$ & $1.35 \mathrm{E}+04$ & $1.91 \mathrm{E}+04$ & $6.25 \mathrm{E}+01$ & $1.25 \mathrm{E}+01$ & & $(3.50 \mathrm{E}+00)$ & $2.50 \mathrm{E}+02$ \\
\hline & & & & & & & & & & $E+02$ & \\
\hline & & +02 & 1) & & & & & & & & +02 \\
\hline & & & & & & & & & & $+00)$ & $E+02$ \\
\hline & & 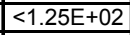 & & & & & & & & & $=250 \mathrm{~F}+0$ \\
\hline & $00 \mathrm{E}+02$ & $<1.25 \mathrm{E}+02$ & $(1.95 E+02)$ & 2.2 & +04 & -04 & $<6.25$ & -01) & $E+01)$ & $<1.25 \mathrm{E}+02$ & $<2.50 \mathrm{E}+02$ \\
\hline & & & & & & & & & & & \\
\hline & UOLTUL & $<1.25 \mathrm{E}+02$ & $(8.17 \mathrm{E}+01)$ & $2.28 \mathrm{E}+$ & +04 & +04 & 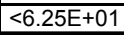 & \begin{tabular}{|l}
$(5.32 \mathrm{E}-01)$ \\
\end{tabular} & $(1.21 \mathrm{E}+01)$ & $(1.25 \mathrm{E}+01)$ & $<2.50 \mathrm{E}+02$ \\
\hline & $<5.00 \mathrm{E}+02$ & $<1.25 \mathrm{E}+02$ & $(2.33$ & 2.4 & & 2.0 & $<6.25 \mathrm{E}+01$ & $<1$. & $(1.1$ & $(4.49 \mathrm{E}+00)$ & $(8.78 \mathrm{E}+00)$ \\
\hline & $4.02 \mathrm{E}+$ & $1.13 \mathrm{E}+02$ & $1.86 \mathrm{E}+02$ & $2.47 \mathrm{E}+04$ & $1.35 \mathrm{E}+04$ & $2.06 \mathrm{E}+04$ & $\mathrm{NA}$ & $3.02 \mathrm{E}+00$ & $1.25 \mathrm{E}+01$ & $5.30 \mathrm{E}+01$ & $1.76 \mathrm{E}+02$ \\
\hline ndard D & $\overline{10}$ & & $1.17 \mathrm{E}+02$ & $5.54 \mathrm{E}+03$ & $4.36 \mathrm{E}+02$ & $2.95 \mathrm{E}+03$ & $\bar{N}$ & $5.01 \mathrm{E}+00$ & $1.42 \mathrm{E}+00$ & $6.20 \mathrm{E}+01$ & $\bar{s}$ \\
\hline
\end{tabular}

Table 6.10. Field Parameters Measured in Samples Collected During the First Baseline Sampling Event (December 2006)

\begin{tabular}{|c|c|c|c|c|c|}
\hline Well Name & $\begin{array}{c}\text { Temperature } \\
\text { deg C }\end{array}$ & $\begin{array}{c}\text { Specific Conductance } \\
\mu \mathrm{S} / \mathrm{cm}\end{array}$ & $\begin{array}{c}\text { Dissolved Oxygen } \\
\mathrm{mg} / \mathrm{L}\end{array}$ & $\mathrm{pH}$ & $\begin{array}{c}\text { ORP } \\
\mathrm{mV}\end{array}$ \\
\hline $399-1-23$ & 16.6 & 474 & 8.81 & 7.35 & 125 \\
\hline $399-1-24$ & 16.6 & 473 & 8.93 & 7.37 & 118 \\
\hline $399-1-27$ & 16.7 & 531 & 6.74 & 7.56 & 119 \\
\hline $399-1-25$ & 16.7 & 475 & 8.4 & 7.41 & 123 \\
\hline $399-1-30$ & 16.6 & 472 & 8.91 & 7.39 & 116 \\
\hline $399-1-31$ & 16.6 & 472 & 8.92 & 7.4 & 119 \\
\hline $399-1-26$ & 16.5 & 471 & 8.88 & 7.41 & 123 \\
\hline $399-1-28$ & 16.7 & 475 & 8.41 & 7.28 & 130 \\
\hline $399-1-29$ & 16.5 & 473 & 8.66 & 7.39 & 128 \\
\hline $399-1-32$ & 16.1 & 474 & 8.31 & 7.41 & 129 \\
\hline Average & 16.56 & 479 & 8.50 & 7.40 & 123 \\
\hline Standard Deviation & 0.18 & 18 & 0.66 & 0.07 & 5 \\
\hline
\end{tabular}


collection (Table 6.10). To a lesser extent, well 399-1-28 (completed next to 1-27 but at a higher elevation) showed elevated uranium concentrations also, but no other analytes were elevated. It is likely that the lower permeability zone causes less dynamic changes in concentrations measured in 399-1-27 relative to the other monitoring wells.

\subsection{Injection Design Analysis}

The objective of the injection design analysis is to determine injection volumes, rates, and sampling requirements for the treatability test. These will be based on the results of the bench-scale studies (Section 2), the tracer injection test that was conducted at the site in December 2006, and the use of analytic and numerical models. The nominal design for the treatability test is described below. Additional details and changes will be documented in field test instructions that will be prepared prior to the polyphosphate injection test. The volumes and rates for the nominal injection design are based on a conservative species (i.e., bromide) as described below along with a description of the numerical model to aid in the design and interpretation of the treatability test. The injection volumes, which are based on the observed arrival of conservative species during the tracer injection test, have been increased to account for increased aquifer thickness during spring high river stage conditions. These volumes will also be increased to account for retardation associated with the reactive species used for the polyphosphate treatability test. Injection volume specifications for the polyphosphate injection are provided in Section 6.7.

\subsubsection{Injection Volume and Rates}

The injection volume for a conservative species at the polyphosphate treatability test site was estimated based on the results of the bromide tracer test and adjusted for the higher river stage conditions expected for the test in June. The targeted treatment volume is for $90 \%$ or greater concentrations at a 7.62-m (25-ft) radial distance from the injection well.

Figures 6.29 and 6.30 show the tracer breakthrough curves during the injection period (714 minutes) of the December 13, $2006 \mathrm{Br}$ - tracer test at the polyphosphate treatability test site. As can be seen in these figures, there is a large variability in the tracer arrivals at the wells due to heterogeneities at the site. Also shown in Figures 6.29 and 6.30 is the results of an analytic solution for advection and dispersion for wells around an injection well at different radial distances at the site (Hoopes and Harleman 1967). This analytic solution assumes a homogeneous, isotropic aquifer with constant thickness. Parameters used for the analytic solution are shown in the figures. Comparisons with the analytic solution are meant to show the relative differences between the measured tracer arrivals using a standard response. This allows the wells to be categorized as fast or slow relative to this measure. Based on these comparisons, most of the wells southeast of the injection well had slower tracer arrivals than wells in other directions. Well 399-1-30, to the southwest of the injection well, had a very fast arrival indicating preferential flow in that direction. Wells to the northeast and northwest had similar arrivals to the average expected at the site. Using the comparison to the analytic solution for well 399-1-29, it appears that the tracer response at this well is influenced by multiply layers within the screened zone as seen by an initial early tracer arrival to about $50 \%$ of the tracer concentration followed by a slow increase during the rest of the injection period. 

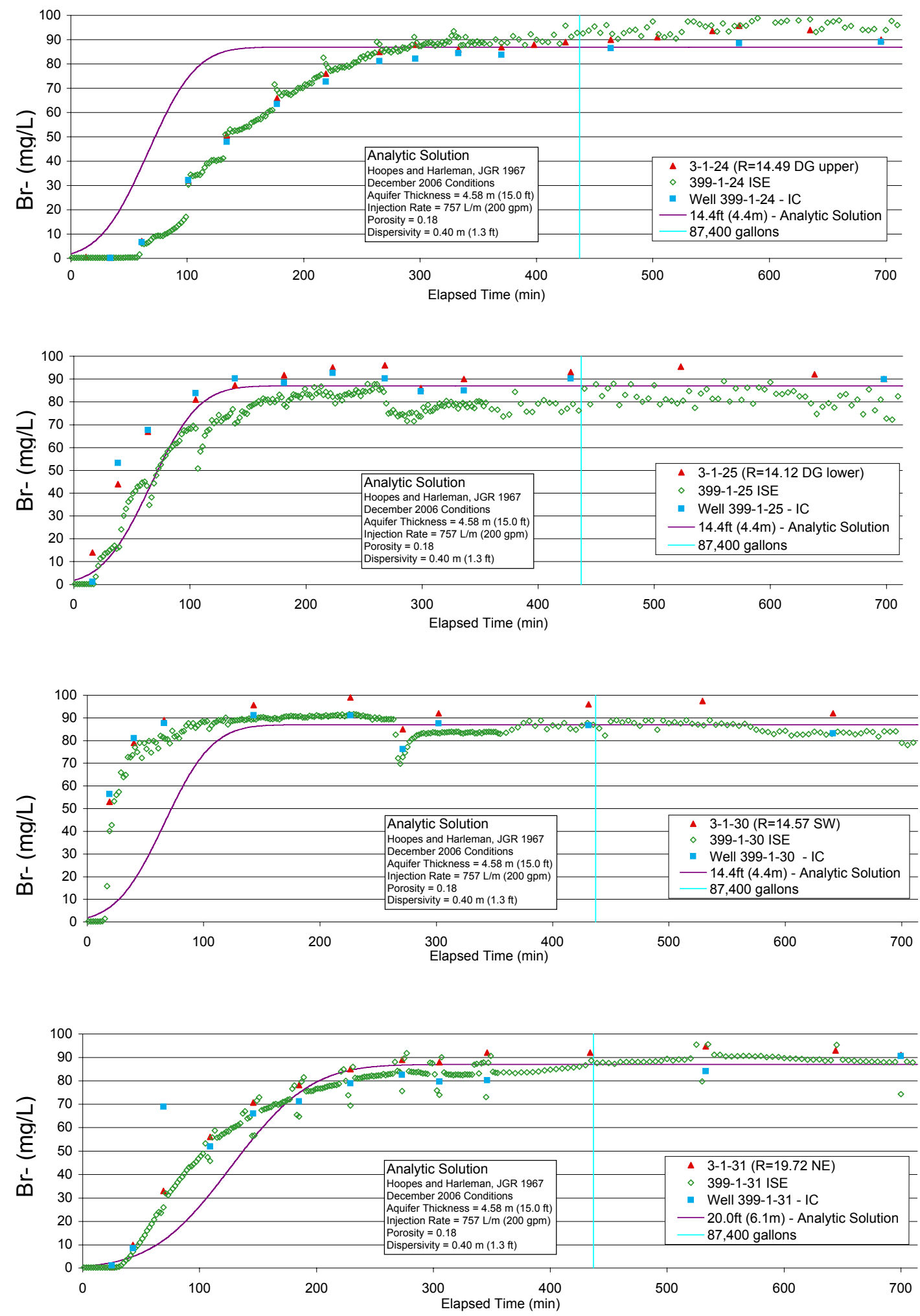

Figure 6.29. Tracer Breakthrough Curves during Injection Period of the December 13, 2006, Bromide Tracer Test 

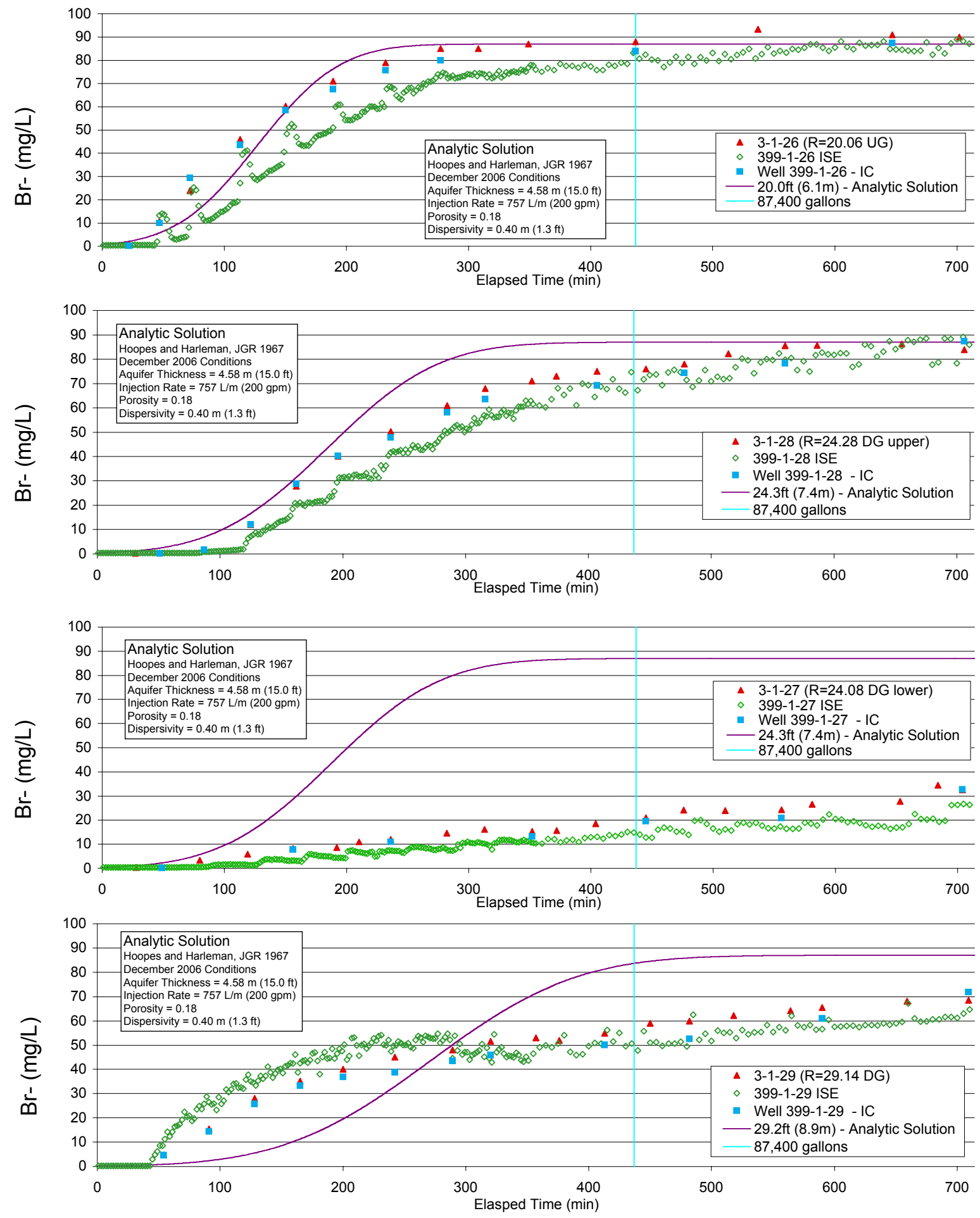

Figure 6.30. Tracer Breakthrough Curves during Injection Period of the December 13, 2006, Bromide Tracer Test 
Table 6.11 summarizes the injection volumes for percentage arrivals of tracer from the breakthrough curves at each of the wells during the December 2006 tracer test at the site. Table 6.12 scaled these percentage tracer volumes for each well with its radial distance adjusted to a 25 -ft radius based on cylindrical geometry. Using this scaling, the average volume from all the wells at the site for a $90 \%$ tracer arrival at $7.6 \mathrm{~m}$ ( $25 \mathrm{feet})$ is $\sim 330,800 \mathrm{~L}$ (87,400 gallons) during the December tracer test. The volume is shown on Figures 6.29 and 6.30 for comparison with the tracer arrivals during the injection. Adjusting for the $25 \%$ increase in aquifer thickness expected due to increased river stage in June, $4.58-\mathrm{m}-$ (15.0-ft-) thick aquifer in December 2006 and an estimated 5.73-m- (18.8-ft-) thick based on May-June 2006300 Area water-table map, results in a 413,500 L (109,200 gal) per pore volume for a 7.6-m (25-ft) radius at high river stage in June. An analytic solution of tracer arrivals in homogeneous, isotropic aquifer under these conditions is shown in Figure 6.31. This is the same method used for the comparison with the measured tracer breakthrough curves in Figures 6.29 and 6.30.

Table 6.11. Estimated Volumes for Tracer Arrivals for Bromide Tracer Test conducted in December 2006

\begin{tabular}{||c|c|c|c|c|c||}
\hline Well Name & $\begin{array}{c}\text { Distance to } \\
\text { Well 399-1-23 } \\
\text { (ft) }\end{array}$ & $\begin{array}{c}50 \% \text { Tracer } \\
\text { Arrival (gal) }\end{array}$ & $\begin{array}{c}80 \% \text { Tracer } \\
\text { Arrival (gal) }\end{array}$ & $\begin{array}{c}\text { 90\% Tracer } \\
\text { Arrival (gal) }\end{array}$ & $\begin{array}{c}\text { 100\% Tracer } \\
\text { Arrival (gal) }\end{array}$ \\
\hline \hline $399-1-23$ & 0.0 & & & & \\
\hline $399-1-24$ & 14.5 & 26,000 & 42,000 & 50,000 & 114,000 \\
\hline $399-1-25$ & 14.1 & 8,000 & 16,000 & 20,000 & 44,000 \\
\hline $399-1-26$ & 20.1 & 22,000 & 40,000 & 56,000 & 130,000 \\
\hline $399-1-27$ & 24.1 & ---- & ---- & ---- & ---- \\
\hline $399-1-28$ & 24.3 & 44,000 & 90,000 & 118,000 & 143,000 \\
\hline $399-1-29$ & 29.1 & 62,000 & 143,000 & ---- & ---- \\
\hline $399-1-30$ & 14.6 & 4,000 & 6,000 & 8,000 & 20,000 \\
\hline $399-1-31$ & 19.7 & 18,000 & 38,000 & 48,000 & 70,000 \\
\hline
\end{tabular}

Table 6.12. Scaled Tracer Arrivals for Wells at the Treatability Test Site to a 7.6-m (25-ft) Radius

\begin{tabular}{|c|c|c|c|c|c||}
\hline Well Name & $\begin{array}{c}\text { Distance to } \\
\text { Well } \\
\text { (ft) }\end{array}$ & $\begin{array}{c}50 \% \text { Tracer } \\
\text { Arrival (gal) }\end{array}$ & $\begin{array}{c}80 \% \text { Tracer } \\
\text { Arrival (gal) }\end{array}$ & $\begin{array}{c}90 \% \text { Tracer } \\
\text { Arrival (gal) }\end{array}$ & $\begin{array}{c}100 \% \text { Tracer } \\
\text { Arrival (gal) }\end{array}$ \\
\hline \hline $399-1-23$ & 0.0 & & & & \\
\hline $399-1-24$ & 14.5 & 77,425 & 125,072 & 148,895 & 339,481 \\
\hline $399-1-25$ & 14.1 & 25,093 & 50,185 & 62,731 & 138,009 \\
\hline $399-1-26$ & 20.1 & 34,175 & 62,136 & 86,990 & 201,940 \\
\hline $399-1-27$ & 24.1 & ---- & --- & --- & --- \\
\hline $399-1-28$ & 24.3 & 46,659 & 95,438 & 125,130 & 151,216 \\
\hline $399-1-29$ & 29.1 & 45,640 & 104,973 & ---- & --- \\
\hline $399-1-30$ & 14.6 & 11,785 & 17,677 & 23,569 & 58,923 \\
\hline $399-1-31$ & 19.7 & 28,941 & 61,099 & 77,177 & 112,550 \\
\hline Average & & $\mathbf{3 8 , 5 3 1}$ & $\mathbf{7 4 , 5 7 5}$ & $\mathbf{8 7 , 4 1 5}$ & $\mathbf{1 6 7 , 2 6 7}$ \\
\hline $\begin{array}{c}\text { Average @ } \\
\text { June WT }\end{array}$ & & $\mathbf{4 8 , 2 9 2}$ & $\mathbf{9 2 , 4 9 2}$ & $\mathbf{1 0 9 , 5 6 1}$ & $\mathbf{2 0 9 , 6 4 2}$ \\
\hline
\end{tabular}




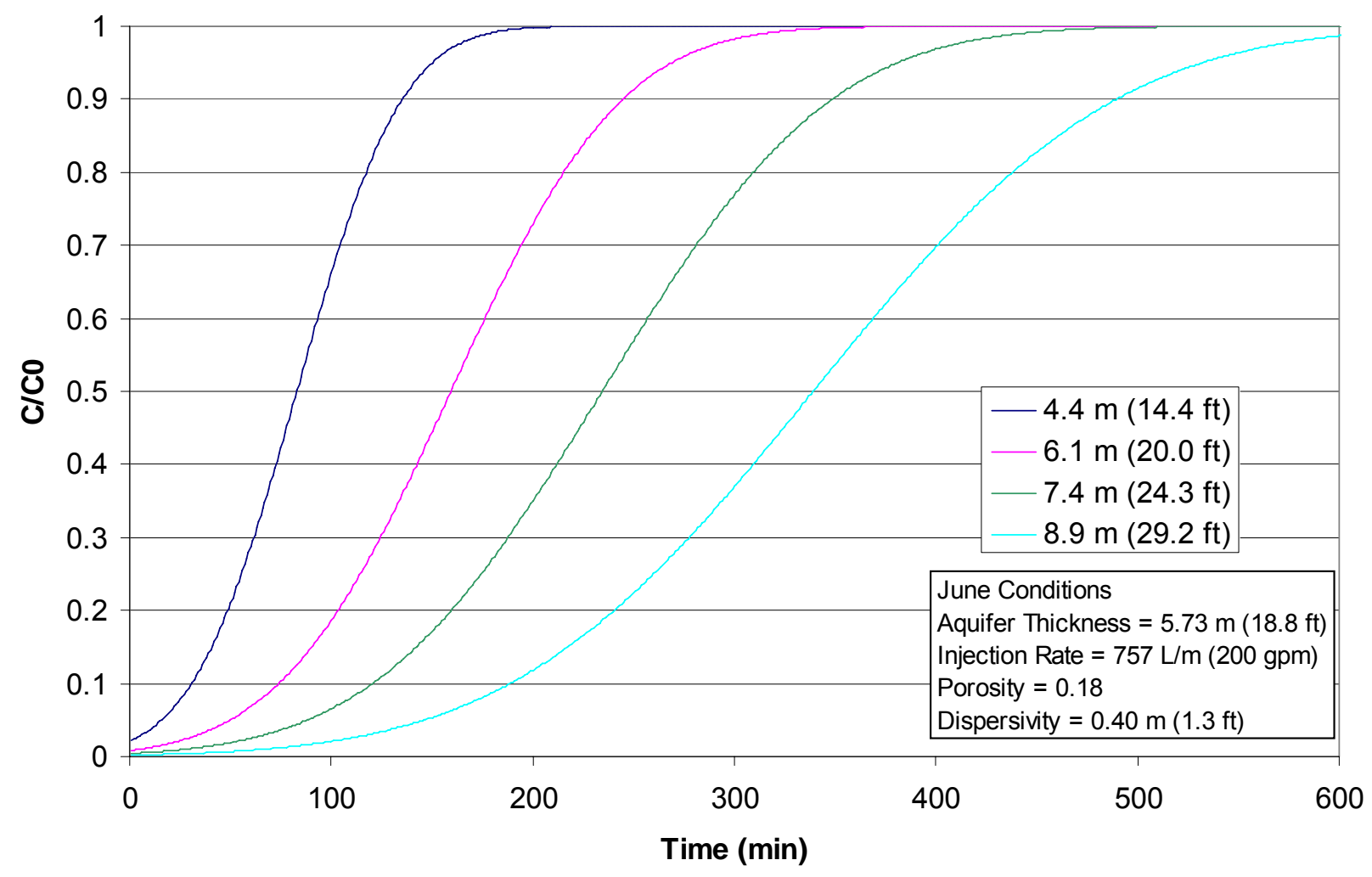

Figure 6.31. Analytic Solution (Hoopes and Harleman 1967) for Tracer Arrivals at Different Radial Distances Using Estimated June Conditions. Parameters: Injection rate is $757 \mathrm{Lpm}$ (200 gpm), $5.73 \mathrm{~m}$ thick aquifer, $18 \%$ porosity, $0.4 \mathrm{~m}$ dispersivitiy, and 454,200 L (120,000 gallons) total volume.

The injection rate of $757 \mathrm{~L}$ ( $200 \mathrm{gal})$ per minute was determined for the design of the bromide tracer test and was used for selecting pump sizes and hoses as part of the site setup. This injection rate was sustained during the tracer injection test by pumping groundwater from Well 399-1-7, mixing with the concentrated tracer solution, and injecting into well 399-1-23. An injection rate of $757 \mathrm{~L}$ (200 gal) per minute will also used for the polyphosphate amendment injection.

\subsubsection{Treatability Test Numerical Model Description}

A numerical model of the site is being developed based on the site characterization (geologic description, physical property measurement of sediment samples, aquifer tests, and tracer test) for help in the design and interpretation of the polyphosphate injection test. The model uses the Subsurface Transport Over Multiple Phases (STOMP) code that is a multi-fluid flow finite difference code that can simulate both the vadose zone and aquifer (White and Oostrom 2000, 2006). This model domain, boundary conditions, material properties, and preliminary simulation results are described in the following sections. 


\subsubsection{Model Domain and Finite Difference Grid}

A plan view of the STOMP finite difference grid for the Polyphosphate Treatability Test model is shown in Figure 6.32. The domain is bounded by wells 399-1-1 and 399-2-2 near the river and wells 399-1-12 and 399-1-2 inland. This model domain does not extend to the Columbia River (within $\sim 50 \mathrm{~m}$ [164 ft] from the shoreline). The vertical domain of the model ranges from 90-m (295-ft) elevation at the bottom to $107.5 \mathrm{~m}(352.68 \mathrm{ft})$ at the top. The bottom of the domain was set below the Hanford formation in the domain and extends a few meters into the Ringold Formation gravels and sands depending on the location (see structure contour map of the top of the Ringold Formation in Figure 6.5). The focus of the treatability study is within the Hanford formation which has hydraulic conductivities many orders of magnitude greater than the underlying Ringold Formation. The upper limit of the model domain was selected based to be above water levels measured in these wells over the past few years.

The finite difference grid is 103 by 91 nodes in the $\mathrm{x}$ and $\mathrm{y}$ directions and 24 nodes in the $\mathrm{z}$ direction (vertically). The total number of nodes in the domain is 224,952 with 190,896 active nodes. The nodes outside the polygon created by the four bounding wells listed above in the rectangular grid are inactive. As shown in Figure 6.32, grid spacing in the $\mathrm{x}-\mathrm{y}$ directions is variable and ranges from 1 to $7 \mathrm{~m} \mathrm{(3.28} \mathrm{to}$ $22.96 \mathrm{ft}$ ). The grid has the highest resolution around the treatability test site for simulating the injection and surrounding monitoring wells in the treatment zone with the grid spacing coarser away from the site. Vertical grid spacing is from 0.5 to $1.5 \mathrm{~m}$ (1.64 to $4.9 \mathrm{ft})$ with the finer resolution near the top of the aquifer.

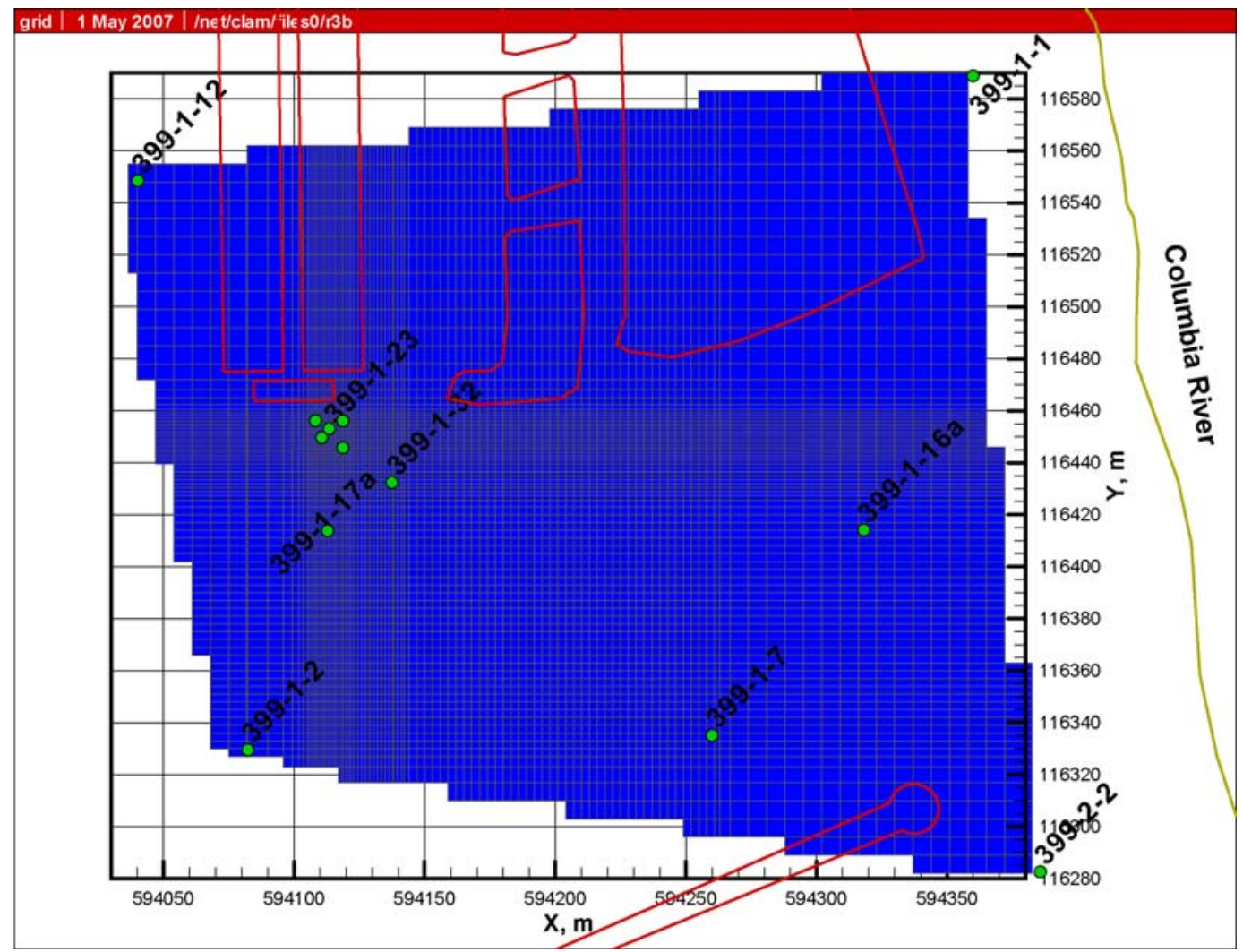

Figure 6.32. Plan View of Polyphosphate Treatability Test STOMP Model Domain and Finite Difference Grid 


\subsubsection{Boundary Conditions}

The lateral boundary conditions of the model are specified hydraulic heads from the four outermost wells shown in Figure 6.32 using data from the 300 Area automated water level monitoring network that has been in operation since 2004 (see description in Section 6.2). Water levels for some of the wells in this network have been collected at up to 15 minute intervals; however, hourly and 2-hour data are used in the model which is sufficient for resolving the daily, weekly, and seasonal fluctuations seen in these hydrographs. Specified heads along the boundaries between these four wells are interpolated in the x-y direction onto the finite difference grid.

Fayer and Walters (1995) generated a Hanford site-wide map of natural groundwater recharge rates by combining available information on land use, vegetation, soil types, lysimeter and tracer $(\mathrm{Cl})$ studies, and numerical simulation. For the 300 Area, their map indicates variable recharge rates, ranging from near zero to $\sim 100 \mathrm{~mm} / \mathrm{yr}$. The Fayer and Walters (1995) recharge map was based, in part, on data from the Buried Waste Test Facility (BWTF) lysimeter, located in the north of the 300 Area. Rockhold et al. (1995, Table 3.1) report an 8-year (1985-1993) record of drainage rates (equivalent to natural ground water recharge) from a bare (unvegetated) lysimeter at the BWTF that range from 111 to $24 \mathrm{~mm} / \mathrm{yr}$, with an average of $55 \mathrm{~mm} / \mathrm{yr}$. Average annual precipitation rates at Hanford have increased slightly since the 1985-1993 time frame, so a higher recharge rate of $60 \mathrm{~mm} / \mathrm{yr}$ was assumed for the upper surface boundary condition in the model. The bottom of the model domain, within the Ringold Formation, is a no-flow boundary.

Williams et al. (2006) used the chloride mass balance method to estimate a recharge rate of $1.8 \mathrm{~mm} / \mathrm{yr}$ for the undisturbed, vegetated area in the vicinity of well 699-S20-E10, located Northwest of the 300 Area. Based on these data, and on the lysimeter data noted above, natural groundwater recharge rates in the 300 Area can be expected to range from an annual average of $<2 \mathrm{~mm} / \mathrm{yr}$ (for undisturbed, vegetated areas) up to $60 \mathrm{~mm} / \mathrm{yr}$ or more (for disturbed, unvegetated areas). Note that this range does not include locally elevated recharge rates that might occur, for example, adjacent to relatively impermeable surfaces such as buildings, roads, and parking lots. The area around the treatability test site has also been undergoing extensive surface remediation over the past decade with the vegetation and top layer of the soil removed and backfilled. Water has also been applied to the surface via water trucks for dust control during these activities.

\subsubsection{Material Properties}

Total and effective porosity for the Hanford formation was set at $18 \%$ based on the physical property measurements from cores as part of the LFI characterization for well 399-1-23 (see Table 6.2) and estimates from the tracer test (see Section 6.3). For unsaturated zone parameters in the STOMP code, a Brooks-Corey function is used along with a Burdine porosity distribution model for aqueous relative permeability. The air-entry pressure and lambda parameters for the Hanford Formation are based on data from Rockhold et al. (1988, p. A.1), which represent the ("L-soil") sediment used in the BWTF lysimeters, located north of the 300 Area. The irreducible saturation parameter, Sr, was estimated at 0.16 based on data from well 699-S20-E10 (see Figure 8 of Williams et al. 2006).

Hydraulic conductivity values for the Hanford Site are very high and variable in the area of the polyphosphate treatability test site. Initial simulations of the tracer test using this STOMP model with uniform hydraulic properties for the Hanford formation in the area of the tracer test resulted in a good 
agreement with the overall tracer plume from the monitoring data, however conflicts between tracer arrivals in different wells required developing different zonations (i.e., need for faster arrivals in some wells and slower arrivals in other wells). Analytic models used for the tracer injection stage data with the monitoring wells within the treatment zone showed a similar need for hydraulic conductivity zonation.

A number of data sources were used for creating hydraulic conductivity zones within the Hanford formation aquifer for the model which are shown in Figure 6.33 for an elevation of $105 \mathrm{~m}(344.48 \mathrm{ft})$ and in Figure 6.34 for an elevation of $102.5 \mathrm{~m}(336.2 \mathrm{ft})$. These data include areas of higher hydraulic gradients in the northeast portion of the current water-level monitoring network (see Section 6.2), differences in tracer breakthrough curves measured in monitoring wells at different orientations and depths during the injection stage of the tracer test, differences in hydraulic gradient and tracer drift downgradient from the site (see Section 6.5), and descriptions from geologic logs during drilling of the wells at the polyphosphate treatability test site (notably a clast-supported gravel that was identified in the bottom portion of the Hanford aquifer in most of the wells except in the southeast direction). Hydraulic conductivity values for these zones are being varied to develop a best-fit case based on the tracer test and hydraulic test characterization results. The starting hydraulic conductivity values for these zones were specified from values determined from the field tests where available as discussed in the site characterization results above.

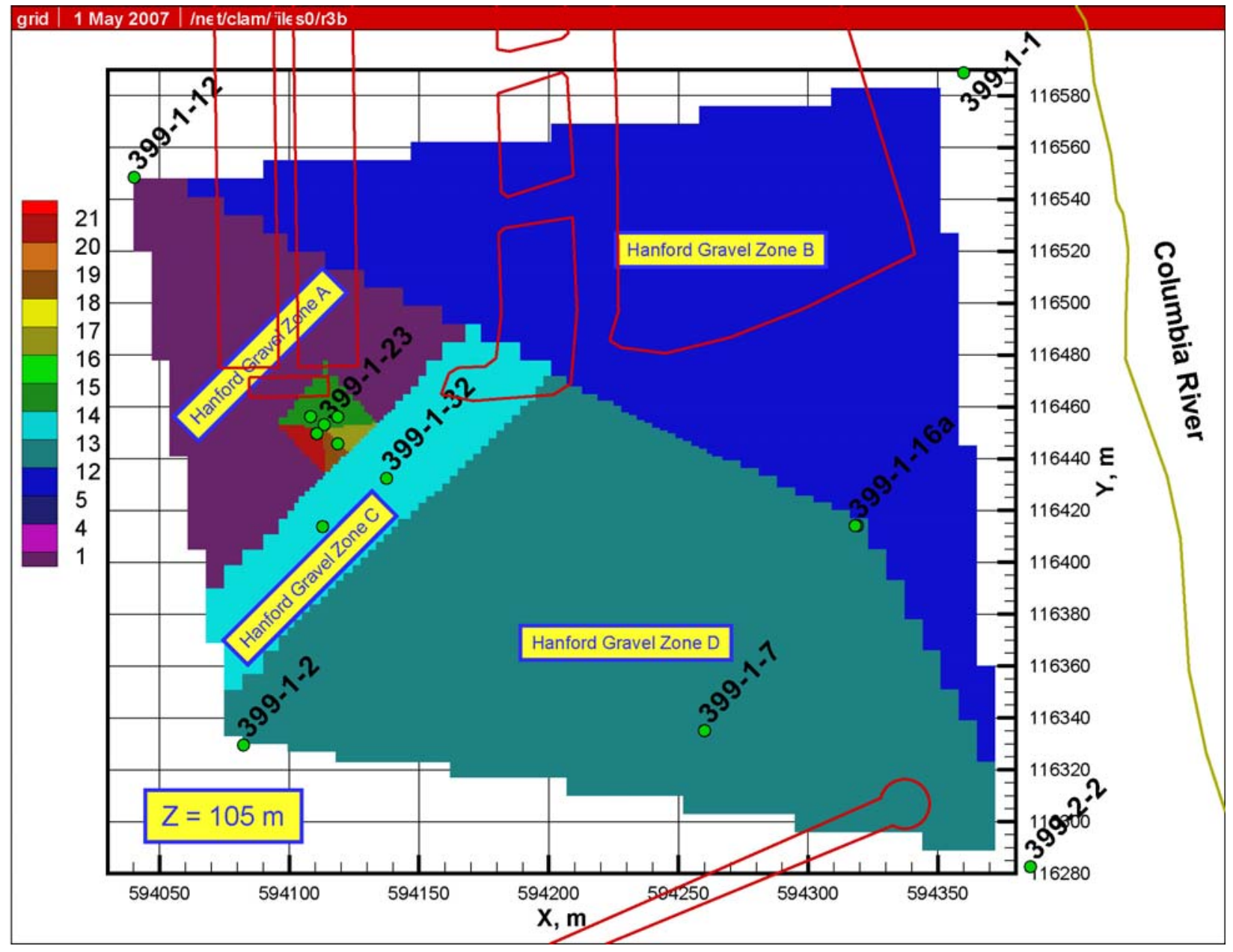

Figure 6.33. Hydrostratigraphic Zonations in Polyphosphate Site Model at $105 \mathrm{~m}$ Elevation 


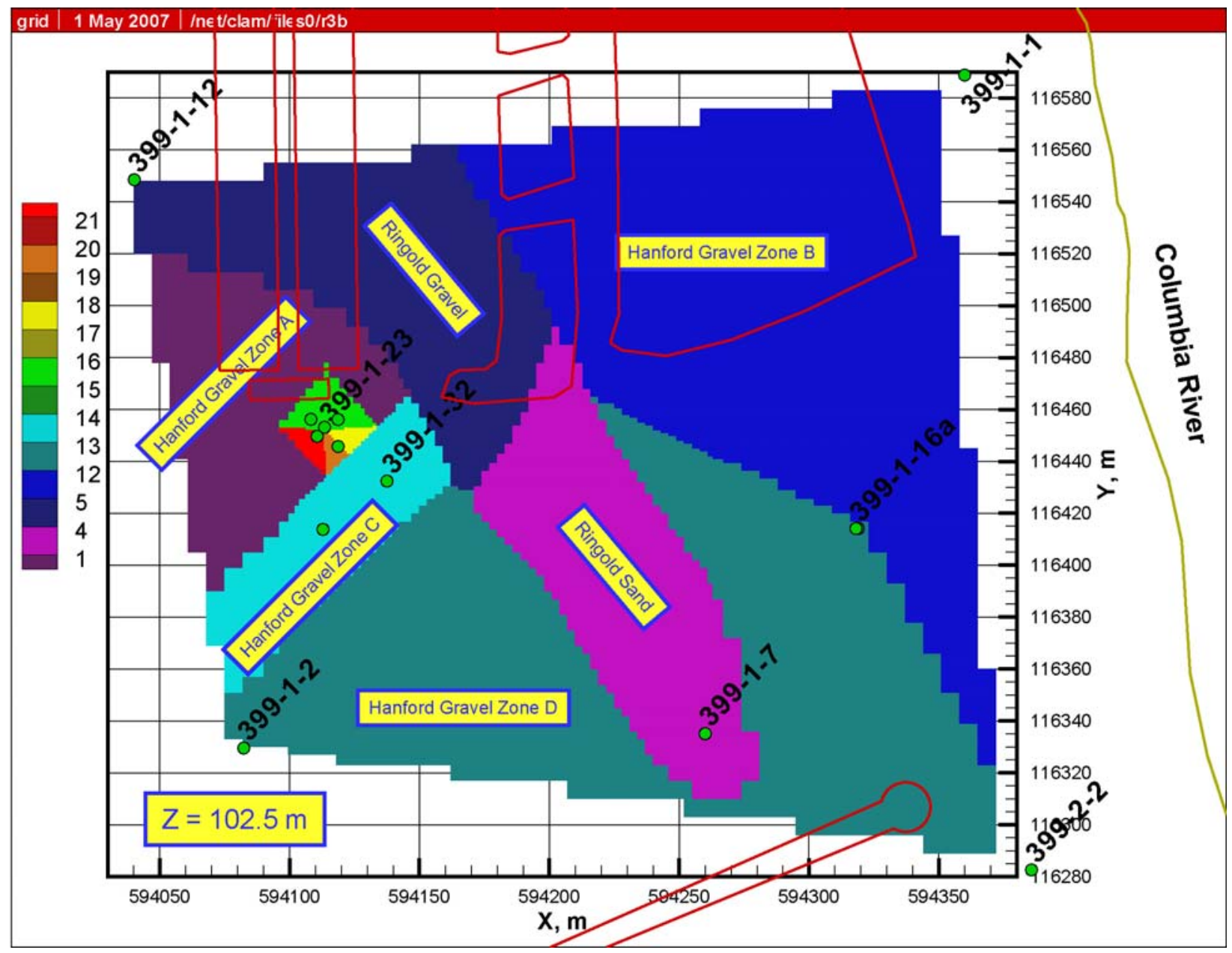

Figure 6.34. Hydrostratigraphic Zonations in Polyphosphate Site Model at $102.5 \mathrm{~m}$ Elevation

\subsubsection{Preliminary Bromide Tracer Test Simulations}

Work on parameter estimates for estimating hydraulic propertied for the zonations shown in Figures 6.33 and 6.34 is ongoing. A manual process is used for estimating these parameters, primarily hydraulic conductivities, by comparing simulated tracer and hydraulic heads with measured values during the tracer test and adjusting the properties.

Preliminary results are shown in Figures 6.35 and 6.36. Figure 6.35 shows the simulated tracer plumes at the end of the injection (12/23/06 10:00 pm) along with selected periods during the tracer drift at 3 days, 14 days, and 28 days. Figure 6.36 compares the simulated values at different node locations within the well screens (s1, s2, and s3) with the measured Br- values (both IC and in situ probe data). These preliminary results show that the simulated values have a good fit for the injection well, but are slow for the downgradient well 399-1-32. Simulated tracer arrivals at the far downgradient well (399-1-7) are within the time period of detected bromide in this well, however the simulated pulse is too short and at slightly higher concentrations. This could be due to the need for higher dispersivity or the trajectory of the simulated plume could be shifted (i.e., off the plume centerline). In addition to changing travel times, the contrast in hydraulic properties also influences the plume trajectory. 

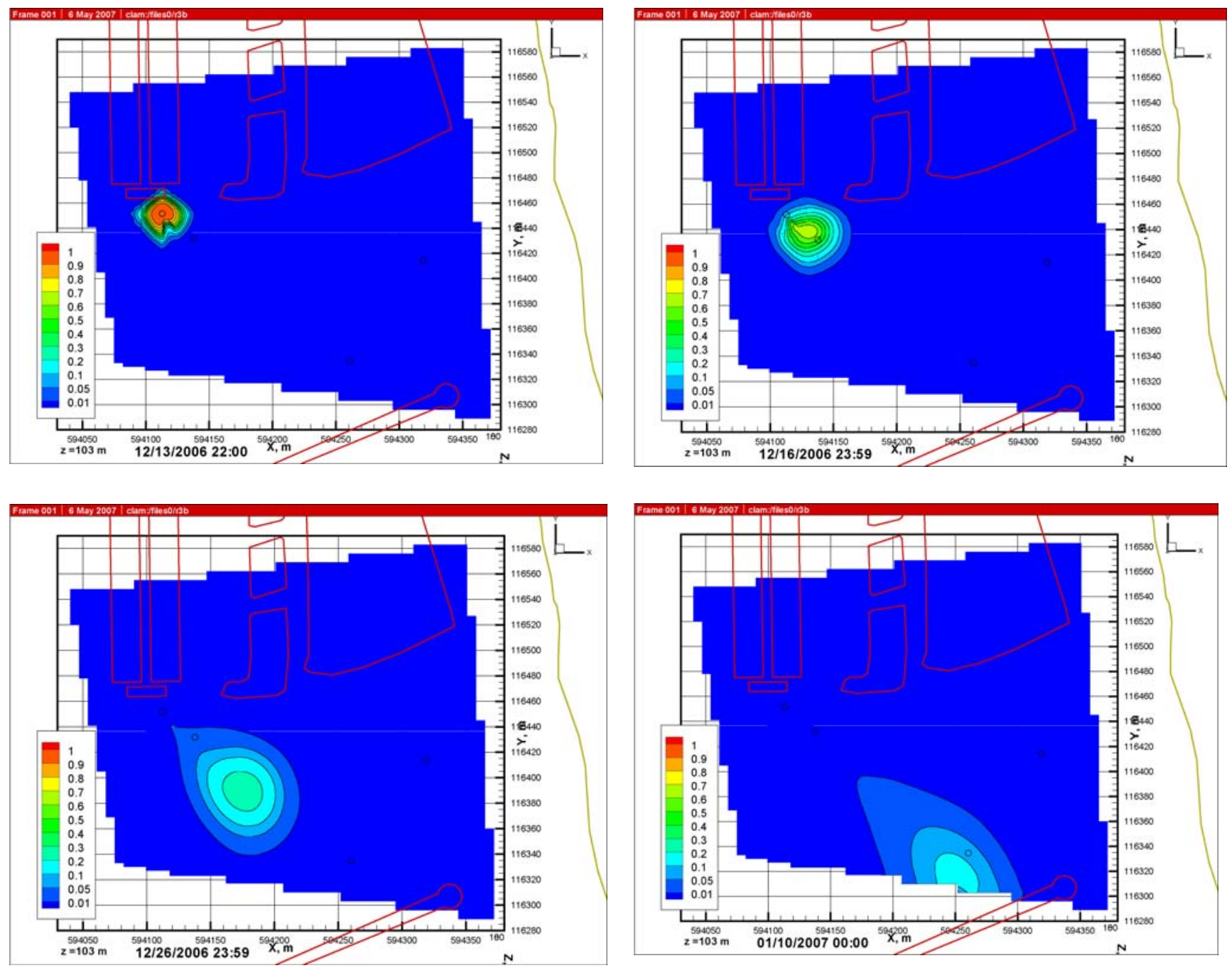

Figure 6.35. Preliminary Results of Polyphosphate Site Model of Bromide Tracer Test. Simulated tracer values at end of injection and for drift periods 3, 14, and 28 days later. Tracer concentrations are normalized $(\mathrm{C} / \mathrm{CO})$. 

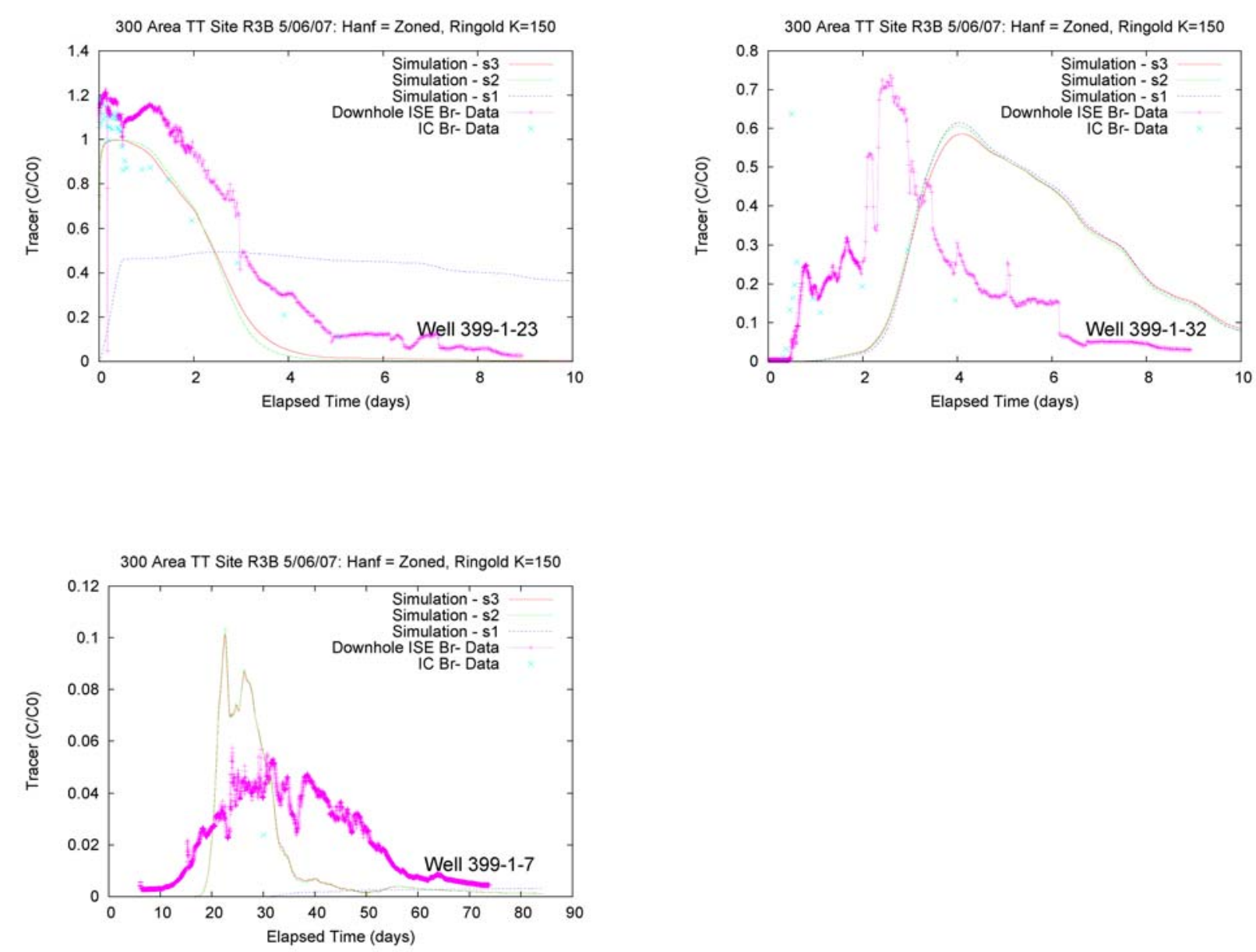

Figure 6.36. Preliminary Results of Polyphosphate Site Model of Bromide Tracer Test. Comparison of measured versus simulated tracer concentrations at wells 399-1-23, 399-1-32, and 399-1-7. s1, s2, and s3 are simulated values at different node positions in the well screen. 


\subsection{Chemical Requirements}

The chemical requirements for the polyphosphate treatability test are based on the bench-scale studies described in Section 2 (particularly Table 2.7) and the determination of the fluid volume required for treatment out to a specific radial distance from the injection well at the field site (as discussed in Section 6.6). The chemicals will be delivered to the site in a concentrated form in tanker trucks. The concentrated solutions from the tanker trucks will be mixed inline with supply water pumped from well 399-1-7 to the specified injection concentrations and injected in well 399-1-23.

Based on the bromide tracer test data and adjusting for the thicker aquifer at the site during June, a

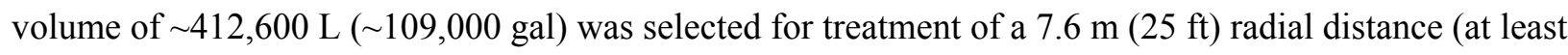
$90 \%$ concentration) from the injection well (399-1-23). This volume is for a non-reacting species; therefore, the volumes are scaled up using the retardation factors determined from the bench-scale tests for the different mixtures used in the test.

The amendment formulation and injection concentrations for the polyphosphate treatability study are shown in Table 2.7. As described in Section 2, the polyphosphate treatability test is composed of three separate injections. The first injection is a polyphosphate amendment for sequestration of the uranium in phosphate mineral phases (i.e., autunite), the second injection is a calcium chloride solution for supplementing the existing calcium in the aquifer for apatite formation, and the third injection is another polyphosphate amendment (same composition as the first injection) for providing phosphate for apatite formation. The injection volumes for the first and third injections are scaled up from $412,600 \mathrm{~L}$ to $990,300 \mathrm{~L}$ (109,000 to 262,000 gal) based on the retardation factor of $\sim 2.4$ for the polyphosphate amendment with sediments from the site. The injection volume for the calcium chloride solution in the second injection was scaled up to $1,980,000 \mathrm{~L}$ (523,000 gallons) based on a retardation factor of 4.8 determined in laboratory experiments for sediments from the site.

Sodium bromide is added to the polyphosphate amendment to provide a conservative tracer for the test (Br-). Using bromide as the tracer for both the first and third injection phases should not cause overlap problems within the injection zone given the large injection volume planned for the second phase of the treatment $(\mathrm{CaCl})$. The chloride that is a component of the second injection solution will be used as a conservative tracer during this phase of the experiment. 


\subsection{Sampling and Analysis}

This section contains the Sampling and Analysis Plan for the polyphosphate treatability test. As indicated in Section 5.2, both aqueous and sediment samples will be collected from the site to assess treatment performance. Specific field sampling protocols will be described in a project-specific Field Test Instruction, to be developed prior to the polyphosphate injection test, once the test design has been finalized. The equipment used to conduct the sampling is described in Section 5.3. The work will comply with applicable subject areas of PNNL's Standards-Based Management System (SBMS) located at https://sbms.pnl.gov and PNL-MA 567, Procedures for Groundwater Investigations. SBMS is a webbased system for communicating PNNL's management systems and procedures through subject areas. Investigation derived waste will be handled in accordance with Hanford Site requirements.

\subsection{Groundwater Sampling and Analysis}

During all groundwater sampling, field parameters $(\mathrm{pH}$, specific conductance, dissolved oxygen, oxidation reduction potential and temperature) will be measured and recorded manually on data sheets which will be copied for distribution. In addition, bromide (and possibly chloride) may be measured as a field parameter during injection monitoring if it can be determined that interference from the polyphosphate amendment will not preclude their use. Calibration of field probes will follow the manufacturer's instructions using standard calibration solutions. Detailed sampling instructions, including which wells to sample and at what frequency, will be posted in the field site trailer prior to initiation of the test.

Groundwater sample collection requirements and location and frequency of sampling are provided in Table 7.1 and Table 7.2, respectively. All analyses will be performed in accordance analytical requirements listed in Table 7.3.

\subsection{Sediment Core Sample Collection}

Following the polyphosphate injection test, sediment core samples will be collected and analyzed in the laboratory to assess treatment effectiveness. Split-spoon (0.6-m [2-ft] long by 10-cm [4-in.] diameter) core samples will be collected from three to five boreholes drilled at different radial distances from the injection wells. The core locations and depths for the spit-spoon samples will be based on amendment arrival responses observed during the injection test and will be specified prior to commencement of drilling.

To maintain the integrity of the sediment core samples, which are being collected for geochemical and/or physical property analysis, samples shall be collected using the following procedure. To facilitate the collection and laboratory handling of the core samples and improve the lithologic description, the Lexan $^{\mathrm{TM}}$ liners shall be 15.24-cm- (6-in.-) long sections. A clean work table shall be available on site for processing the core and cleaning the sampling equipment/materials. The table shall be covered with clean plastic sheeting and protected from wind and blowing dust particles. 
Table 7.1. Groundwater Chemistry Sampling Requirements

\begin{tabular}{|c|c|c|c|c|c|}
\hline Parameter & $\begin{array}{l}\text { Media/ } \\
\text { Matrix }\end{array}$ & Monitoring Phase & $\begin{array}{l}\text { Volume/ } \\
\text { Container }\end{array}$ & Preservation & $\begin{array}{l}\text { Holding } \\
\text { Time }\end{array}$ \\
\hline \multicolumn{6}{|c|}{ "Water Quality Parameters } \\
\hline $\begin{array}{l}\text { Major Cations: } \\
\mathrm{Al}, \mathrm{As}, \mathrm{B}, \mathrm{Ba}, \mathrm{Bi}, \mathrm{Ca}, \\
\mathrm{Co}, \mathrm{Fe}, \mathrm{K}, \mathrm{Mg}, \mathrm{Mn}, \mathrm{Ni} \\
\mathrm{Zn}, \mathrm{Zr}, \mathrm{P}, \mathrm{Sr}, \mathrm{Na}, \mathrm{Si}, \mathrm{S}, \\
\mathrm{Sb}\end{array}$ & Water & $\begin{array}{l}\text { Pre-Test Monitoring } \\
\text { Injection Monitoring } \\
\text { Performance Monitoring }\end{array}$ & $\begin{array}{l}20-\mathrm{ml} \text { plastic } \\
\text { vial }\end{array}$ & \begin{tabular}{|l} 
Filtered \\
$(0.45 \mu \mathrm{m})$, \\
unfiltered dup. \\
at $20 \%$ level \\
$\mathrm{HNO}_{3}$ to $\mathrm{pH}<2$ \\
\end{tabular} & 60 Days \\
\hline $\begin{array}{l}\text { RCRA/Trace Metals: } \\
\mathrm{Cr}, \mathrm{Cu}, \mathrm{As}, \mathrm{Se}, \mathrm{Mo}, \mathrm{Ag}, \\
\mathrm{Cd}, \mathrm{Pb}, \mathrm{U}\end{array}$ & Water & $\begin{array}{l}\text { Pre-Test Monitoring } \\
\text { Performance Monitoring }\end{array}$ & $\begin{array}{l}20-\mathrm{ml} \text { plastic } \\
\text { vial }\end{array}$ & $\begin{array}{l}\text { Filtered } \\
(0.45 \mu \mathrm{m}), \\
\mathrm{HNO}_{3} \text { to } \mathrm{pH}<2\end{array}$ & 60 Days \\
\hline $\begin{array}{l}\text { Anions: } \mathrm{Cl}^{-}, \mathrm{Br}^{-}, \mathrm{SO}_{4}{ }^{2-} \text {, } \\
\mathrm{PO}_{4}{ }^{3-}, \mathrm{NO}_{2}{ }^{-}, \mathrm{NO}_{3}{ }^{-}\end{array}$ & Water & $\begin{array}{l}\text { Pre-Test Monitoring } \\
\text { Injection Monitoring } \\
\text { Performance Monitoring }\end{array}$ & $\begin{array}{l}20-\mathrm{ml} \text { plastic } \\
\text { vial }\end{array}$ & $\mathrm{Cool} 4^{\circ} \mathrm{C}$ & 45 Days \\
\hline \multicolumn{6}{|c|}{ Parameters measured with Field Probes } \\
\hline Bromide or chloride & Water & $\begin{array}{l}\text { Monitored during each } \\
\text { sampling event }\end{array}$ & $\begin{array}{l}\text { Field } \\
\text { Measurement }\end{array}$ & None & N/A \\
\hline $\mathrm{pH}$ & Water & $\begin{array}{l}\text { Monitored during each } \\
\text { sampling event }\end{array}$ & $\begin{array}{l}\text { Field } \\
\text { Measurement }\end{array}$ & None & $\mathrm{N} / \mathrm{A}$ \\
\hline Specific Conductance & Water & $\begin{array}{l}\text { Monitored during each } \\
\text { sampling event }\end{array}$ & $\begin{array}{l}\text { Field } \\
\text { Measurement }\end{array}$ & None & N/A \\
\hline Dissolved Oxygen & Water & $\begin{array}{l}\text { Monitored during each } \\
\text { sampling event }\end{array}$ & $\begin{array}{l}\text { Field } \\
\text { Measurement }\end{array}$ & None & N/A \\
\hline $\begin{array}{l}\text { Oxidation-Reduction } \\
\text { Potential }\end{array}$ & Water & $\begin{array}{l}\text { Monitored during each } \\
\text { sampling event }\end{array}$ & $\begin{array}{l}\text { Field } \\
\text { Measurement }\end{array}$ & None & N/A \\
\hline Temperature & Water & $\begin{array}{l}\text { Monitored during each } \\
\text { sampling event }\end{array}$ & $\begin{array}{l}\text { Field } \\
\text { Measurement }\end{array}$ & None & N/A \\
\hline
\end{tabular}


Table 7.2. Sampling Frequency and Location

\begin{tabular}{|c|c|c|c|}
\hline Parameter & Monitoring Phase & Sampling Location & Sampling Frequency \\
\hline \multirow{3}{*}{$\begin{array}{l}\text { Major Cations: } \\
\mathrm{Al}, \mathrm{As}, \mathrm{B}, \mathrm{Ba}, \mathrm{Bi} \text {, } \\
\mathrm{Ca}, \mathrm{Co}, \mathrm{Fe}, \mathrm{K}, \mathrm{Mg} \text {, } \\
\mathrm{Mn}, \mathrm{Ni}, \mathrm{Zn}, \mathrm{Zr}, \mathrm{P} \text {, } \\
\mathrm{Sr}, \mathrm{Na}, \mathrm{Si}, \mathrm{S}, \mathrm{Sb}\end{array}$} & $\begin{array}{l}\text { Pre-Test } \\
\text { Monitoring }\end{array}$ & $\begin{array}{l}\text { All wells }(399-23,-24, \\
-25,-26,-27,-28,-29,-30 \\
-31,-32,-33,-34,-35,-36 \\
-37, \text { and }-38)\end{array}$ & 3 times prior to injection \\
\hline & $\begin{array}{l}\text { Injection } \\
\text { Monitoring }\end{array}$ & All wells (see above list) & $\begin{array}{l}\text { Sufficient frequency to adequately describe } \\
\text { amendment arrival and transport response }\end{array}$ \\
\hline & $\begin{array}{l}\text { Performance } \\
\text { Monitoring }\end{array}$ & $\begin{array}{l}\text { Selected wells (see above } \\
\text { list) }\end{array}$ & $\begin{array}{l}\text { A minimum of } 3 \text { post-injection sampling } \\
\text { events }\end{array}$ \\
\hline \multirow{2}{*}{$\begin{array}{l}\text { RCRA/Trace } \\
\text { Metals: } \\
\mathrm{Cr}, \mathrm{Cu}, \mathrm{As}, \mathrm{Se}, \\
\mathrm{Mo}, \mathrm{Ag}, \mathrm{Cd}, \mathrm{Pb}, \mathrm{U}\end{array}$} & $\begin{array}{l}\text { Pre-Test } \\
\text { Monitoring } \\
\end{array}$ & All wells (see above list) & 3 times prior to injection \\
\hline & $\begin{array}{l}\text { Performance } \\
\text { Monitoring }\end{array}$ & $\begin{array}{l}\text { Selected wells (see above } \\
\text { list) }\end{array}$ & $\begin{array}{l}\text { A minimum of } 3 \text { post-injection sampling } \\
\text { events }\end{array}$ \\
\hline \multirow[t]{3}{*}{$\begin{array}{l}\text { Anions: } \mathrm{Cl}^{-}, \mathrm{Br}^{-} \\
\mathrm{SO}_{4}{ }^{2-}, \mathrm{PO}_{4}{ }^{3-}, \mathrm{NO}_{2}^{-}\end{array}$} & $\begin{array}{l}\text { Pre-Test } \\
\text { Monitoring }\end{array}$ & All wells (see above list) & 3 times prior to injection \\
\hline & $\begin{array}{l}\text { Injection } \\
\text { Monitoring }\end{array}$ & All wells (see above list) & $\begin{array}{l}\text { Sufficient frequency to adequately describe } \\
\text { amendment arrival and transport response }\end{array}$ \\
\hline & $\begin{array}{l}\text { Performance } \\
\text { Monitoring }\end{array}$ & $\begin{array}{l}\text { Selected wells (see above } \\
\text { list) }\end{array}$ & $\begin{array}{l}\text { A minimum of } 3 \text { post-injection sampling } \\
\text { events }\end{array}$ \\
\hline Field Parameters & $\begin{array}{l}\text { Each Sampling } \\
\text { Event }\end{array}$ & All wells (see above list) & $\begin{array}{l}\text { Collected for each sample, and more } \\
\text { frequently if necessary to characterize arrival } \\
\text { curves and monitor injection performance }\end{array}$ \\
\hline
\end{tabular}


Table 7.3. Analytical Requirements

\begin{tabular}{|c|c|c|c|c|}
\hline Parameter & Analysis Method & $\begin{array}{l}\text { Detection Limit } \\
\text { or (Range) }\end{array}$ & $\begin{array}{l}\text { Typical } \\
\text { Precision/ } \\
\text { Accuracy }\end{array}$ & QC Requirements \\
\hline $\begin{array}{l}\text { Major Cations/Metals: } \\
\mathrm{Ca}, \mathrm{Fe}, \mathrm{K}, \mathrm{Mg}, \mathrm{P}, \mathrm{Na} \\
\mathrm{Si}, \mathrm{S}, \mathrm{Al}, \mathrm{B}, \mathrm{Ba}, \mathrm{Bi}, \mathrm{Ni} \text {, } \\
\mathrm{Zn}, \mathrm{Zr}, \mathrm{Sr}\end{array}$ & $\begin{array}{l}\text { ICP-OES, PNNL- } \\
\text { AGG-ICP-AES } \\
\text { (similar to EPA } \\
\text { Method 6010B) }\end{array}$ & $\begin{array}{l}1 \mathrm{mg} / \mathrm{L} \\
0.1 \mathrm{mg} / \mathrm{L}\end{array}$ & $\pm 10 \%$ & $\begin{array}{l}\text { Daily calibration; blanks } \\
\text { and duplicates and matrix } \\
\text { spikes at } 10 \% \text { level per } \\
\text { batch of } 20 .\end{array}$ \\
\hline $\begin{array}{l}\text { RCRA / Trace Metals: } \\
\mathrm{Cr}, \mathrm{Cu}, \mathrm{As}, \mathrm{Se}, \mathrm{Mo}, \mathrm{Ag}, \\
\mathrm{Cd}, \mathrm{Pb}, \mathrm{U}\end{array}$ & $\begin{array}{l}\text { ICP-MS, PNNL-AGG- } \\
415 \text { (similar to EPA } \\
\text { Method 6020) }\end{array}$ & $\begin{array}{c}1 \mu \mathrm{g} / \mathrm{L} \text { for trace } \\
\text { elements }\end{array}$ & $\pm 10 \%$ & $\begin{array}{l}\text { Daily calibration; blanks } \\
\text { and duplicates and matrix } \\
\text { spikes at } 10 \% \text { level per } \\
\text { batch of } 20 .\end{array}$ \\
\hline $\begin{array}{l}\text { Anions: } \mathrm{Cl}^{-}, \mathrm{Br}^{-}, \mathrm{SO}_{4}{ }^{2-} \\
\mathrm{PO}_{4}{ }^{3-}, \mathrm{NO}_{2}{ }^{-}, \mathrm{NO}_{3}{ }^{-}\end{array}$ & $\begin{array}{l}\text { Ion Chromatography, } \\
\text { AGG-IC-001 (based } \\
\text { on EPA Method } \\
\text { 300.0A) }\end{array}$ & $1 \mathrm{mg} / \mathrm{L}$ & $\pm 15 \%$ & $\begin{array}{l}\text { Daily calibration; blanks } \\
\text { and duplicates at } 10 \% \\
\text { level per batch of } 20 .\end{array}$ \\
\hline Bromide and chloride & Ion selective electrode & $\begin{array}{c}0.4 \text { to } 79,900 \\
\mathrm{mg} / \mathrm{L}\end{array}$ & $\begin{array}{l} \pm 5 \% \\
\text { For indication } \\
\text { only }\end{array}$ & $\begin{array}{l}\text { Follow manufacturer } \\
\text { recommendations }\end{array}$ \\
\hline $\mathrm{pH}$ & $\mathrm{pH}$ electrode & 2 to $12 \mathrm{pH}$ units & $\begin{array}{l} \pm 0.2 \mathrm{pH} \text { unit } \\
\text { For indication } \\
\quad \text { only }\end{array}$ & $\begin{array}{l}\text { User calibrate, follow } \\
\text { manufacturer } \\
\text { recommendations }\end{array}$ \\
\hline Specific conductance & Electrode & 0 to $100 \mathrm{mS} / \mathrm{cm}$ & $\begin{array}{l} \pm 1 \% \text { of reading } \\
\text { For indication } \\
\text { only }\end{array}$ & $\begin{array}{l}\text { User calibrate, follow } \\
\text { manufacturer } \\
\text { recommendations }\end{array}$ \\
\hline Dissolved oxygen & Membrane electrode & 0 to $20 \mathrm{mg} / \mathrm{L}$ & $\begin{array}{l} \pm 0.2 \mathrm{mg} / \mathrm{L} \\
\text { For indication } \\
\quad \text { only }\end{array}$ & $\begin{array}{l}\text { User calibrate, follow } \\
\text { manufacturer } \\
\text { recommendations }\end{array}$ \\
\hline $\begin{array}{l}\text { Oxidation-Reduction } \\
\text { Potential }\end{array}$ & Electrode & -999 to $999 \mathrm{mV}$ & $\begin{array}{l} \pm 25 \mathrm{mV} \\
\text { For indication } \\
\quad \text { only }\end{array}$ & $\begin{array}{l}\text { User calibrate, follow } \\
\text { manufacturer } \\
\text { recommendations }\end{array}$ \\
\hline Temperature & Thermocouple & 5 to $50^{\circ} \mathrm{C}$ & $\begin{array}{l} \pm 0.2^{\circ} \mathrm{C} \\
\text { For indication } \\
\quad \text { only }\end{array}$ & Factory calibration \\
\hline \multicolumn{5}{|c|}{$\begin{array}{l}\text { ICP }=\text { Inductively coupled plasma. } \\
\text { MS }=\text { Mass spectrometry. } \\
\text { OES }=\text { Optical emission spectrometry. }\end{array}$} \\
\hline
\end{tabular}


Sediment core samples collected using the split-spoon sampler will be processed by PNNL field personnel or designee prior to initial sampling and immediately following retrieval of the sampler, as follows:

- All sampling equipment/materials that come in contact with the collected sediment sample, including the Lexan ${ }^{\mathrm{TM}}$ liner material, end caps, and the sampler shoe, should be clean prior to use. If required, sampling equipment and materials should be cleaned in Alconox (or equivalent) and water prior to use. The split-spoon, head, shoe, spacer, core-catcher and liners will be assembled by personnel wearing disposable gloves.

- The drilling contractor will retrieve, disassemble, and place the lower half of the split-spoon sampler containing the Lexan ${ }^{\mathrm{TM}}$ lined sediment samples onto the work table. Disposable gloves should be worn while handling the sampler.

- Immediately cap both ends of the Lexan ${ }^{\mathrm{TM}}$ liner with vinyl end caps.

- Use clean paper towels to wipe the outside of the capped liners free of silt and sand and use duct tape to seal the end caps. Write the date and time the sample was collected, the well number, and the sampler's initials on the Lexan ${ }^{\mathrm{TM}}$ liner. Note the total drive depth provided by the driller, calculate the approximate depth associated with the top and bottom ends of each core section, and record these depths on the liner.

- Also record on each liner section: (1) Sample ID number (if different than the well number) and (2) an arrow pointing in the up direction.

- Samples should be placed in an iced cooler as soon as possible after collection and shipped to the laboratory

If representative samples cannot be collected (for example, if large particles do not fit in the container), notes describing the condition of the sample will be put in the geologist's log. All recovered core samples shall be radiation released (if required), labeled, and delivered to the PNNL point-of-contact for transfer to the PNNL onsite laboratory.

Continuous geologic descriptions of drill cuttings or core shall be recorded as a continuous borehole $\log$. The log will include descriptions of the following:

- Drilling conditions and changes in drilling conditions (e.g., drilling method, drill rate, addition of fluids, heaving sand)

- Depths and types of all collected samples

- Lithologic descriptions of sediments, including relative moisture

- Results of radiation and chemical monitoring of sediments

- Water level and changes in water level with drill depth.

\subsection{Post Treatment Sediment Analysis}

Following the polyphosphate injection test, sediment core samples, collected as outlined above, will be analyzed in the laboratory to assess treatment effectiveness. The core samples will be initially screened using fluorescence spectroscopy to evaluate the formation and location of uranium solid phases 
within the sedimentary matrix. Based on initial fluorescence pre-screening, the bulk core sediment samples will be subsectioned following ASTM method D3976-92 to provide representative samples for solid phase identification, selective extraction, and column testing.

Solid phase identification of the sediment samples will be conducted to characterize the basic chemical characteristics of the sediments as well as the solid phases of uranium present. Major elements in the sediments, including total uranium will be measured by x-ray fluorescence (XRF). X-ray diffraction (XRD) and scanning electron microscopy-energy dispersive spectroscopy (SEM-EDS) will be utilized to identify precipitated uranium phases. The semi-selective chemical extraction technique (Tessier et al. 1979, with modifications) will be used to determine the percentage of uranium present in the extractable phases of water soluble, cation-exchangeable, carbonate solid bearing compounds; amorphous oxides; organic matter; crystalline Fe[III] oxides; and strong acid leachable compounds (Table 7.4). The residual uranium content in the remaining bulk sediment will be measured by XRF.

Column studies will be conducted on sediment cores extracted from the remediation area following treatment to quantify the efficacy of the polyphosphate amendment for the immobilization of uranium. Representative sediment samples will be packed into polyvinyl chloride (PVC) columns (length, $L=$ $30.48 \mathrm{~cm}$; radius, $r=2.54 \mathrm{~cm}$; and bulk volume, $V_{b}=194.04-202.20 \mathrm{~cm}^{3}$ ), uncontaminated Hanford groundwater will be utilized to leach the columns. ICP-MS, ICP-OES, IC will be used for quantifiable aqueous cation and anion analyses.

Based on the types of uranium phases identified in this study, appropriate stability criteria will be incorporated into a site specific reactive transport model (see Section 6.6.2) enabling long-term prediction of the fate of uranium under conditions relevant to the 300-Area aquifer. 
Table 7.4. Semi-Selective Chemical Extraction Procedure

\begin{tabular}{|c|c|c|c|}
\hline Solid to Solution & Reagent & Phases Dissolved & Details \\
\hline $\begin{array}{l}5 \mathrm{~g} \text { of sediment to } \\
40 \mathrm{mLs} \text { of solution }\end{array}$ & DI water & Soluble & Shake 1 hour at room temperature \\
\hline \multicolumn{4}{|c|}{ No need to wash between steps } \\
\hline $5 \mathrm{~g}$ to $40 \mathrm{mLs}$ & $\begin{array}{c}0.1 \mathrm{M} \mathrm{Mg}\left(\mathrm{NO}_{3}\right)_{2} \text { at } \\
\text { pH between } 7.5 \text { and } \\
8.5\end{array}$ & Adsorbed & Shake 1 hour at room temperature \\
\hline \multicolumn{4}{|c|}{ Wash 15 minutes with 20 mLs DI water, centrifuge and add to Mg nitrate extract } \\
\hline $5 \mathrm{~g}$ to $40 \mathrm{mLs}$ & $\begin{array}{c}\text { 1 M NaOAC@ } \\
\text { pH=5 with acetic } \\
\text { acid }\end{array}$ & $\begin{array}{l}\text { Carbonate } \\
\text { Minerals }\end{array}$ & Shake 1 hour at room temperature \\
\hline \multicolumn{4}{|c|}{ Wash 15 minutes with 20 mLs DI water, centrifuge and add to Sodium Acetate } \\
\hline $5 \mathrm{~g}$ to $200 \mathrm{mLs}$ & $\begin{array}{l}10.9 \mathrm{~g} / \mathrm{L} \text { oxalic acid } \\
(0.12 \mathrm{M})+16.1 \mathrm{~g} / \mathrm{L} \\
\text { Amm. Oxalate }(0.11 \\
\mathrm{M}) ; \mathrm{pH} \sim 3\end{array}$ & $\begin{array}{l}\text { Amp. Fe, } \mathrm{Al}, \mathrm{Mn}, \\
\text { Si oxides }\end{array}$ & Shake in dark for $4 \mathrm{hrs}$ at room temperature \\
\hline \multicolumn{4}{|c|}{ Wash 15 minutes with 30 mL DI water, centrifuge and add to Oxalate. } \\
\hline $5 \mathrm{~g}$ to $40 \mathrm{mLs}$ & $\begin{array}{c}\text { Mix } 15 \mathrm{~mL} \text { of } 0.02 \\
\mathrm{M} \text { nitric acid and } 25 \\
\mathrm{ml} \text { of } 30 \% \mathrm{H}_{2} \mathrm{O}_{2} \\
\text { Later add } \\
\text { ammonium } \\
\text { acetate/nitric acid }\end{array}$ & Organics & $\begin{array}{l}\text { Heat to } 85 \mathrm{C} \text { for two hours; add additional } \\
25 \mathrm{ml} \text { of } 30 \% \mathrm{H}_{2} \mathrm{O}_{2} \text { and heat to } 85 \mathrm{C} \text { for three } \\
\text { hours, add } 40 \mathrm{mls} \text { of } 1 \mathrm{M} \text { ammonium acetate/ } \\
\text { nitric acid to } \mathrm{pH}=2 \text {, shake } 30 \text { minutes and } \\
\text { extract }\end{array}$ \\
\hline \multicolumn{4}{|c|}{ Wash 15 minutes with $30 \mathrm{~mL}$ DI, centrifuge and add to Am acetate } \\
\hline $5 \mathrm{~g}$ to $200 \mathrm{mLs}$ & $\begin{array}{c}0.3 \mathrm{M} \text { trisodium } \\
\text { citrate, } 0.2 \mathrm{M} \\
\mathrm{NaHCO}_{3}, 1 \mathrm{~g} / \mathrm{g} \\
\text { sample sodium } \\
\text { dithionite; } \mathrm{pH} \sim 8.3\end{array}$ & $\begin{array}{l}\text { Crystalline Fe } \\
\text { oxides, } \\
\text { hydroxides, } \\
\text { oxyhydroxides }\end{array}$ & $\begin{array}{l}\text { Stir for } 30 \text { minutes at } 85^{\circ} \mathrm{C} \text {; repeat extraction } \\
\text { (total } 2 \text { times, combine leachate) }\end{array}$ \\
\hline \multicolumn{4}{|c|}{ Wash 15 minutes with $60 \mathrm{~mL}$ DI water, centrifuge and add to citrate extract } \\
\hline $\begin{array}{l}5 \mathrm{~g} \text { to } \sim 50 \mathrm{mLs} \text { at } \\
\text { start; then cook until } \\
\text { there is just enough } \\
\text { extract to pull off for } \\
\text { ICP/ICP-MS }\end{array}$ & $8 \mathrm{M} \mathrm{HNO}_{3}$ & Clays, U oxides & $\begin{array}{l}\text { Add } 50 \mathrm{~mL} \text { of } 8 \mathrm{M} \mathrm{HNO}_{3} \text {, mix the slurry and } \\
\text { cover with a watch glass. Heat the sample to } \\
95^{\circ} \mathrm{C} \text { and reflux for } 10 \text { to } 15 \text { minutes without } \\
\text { boiling. Allow the sample to cool, add } 5 \mathrm{~mL} \text { of } \\
\text { concentrated } \mathrm{HNO}_{3} \text {, replace the cover and } \\
\text { reflux for } 30 \text { minutes. If brown fumes are } \\
\text { generated, indicating oxidation of the sample } \\
\text { by } \mathrm{HNO}_{3} \text {, repeat this step (addition of } 5 \mathrm{~mL} \text { of } \\
\text { conc. } \mathrm{HNO}_{3} \text { ) until no brown fumes are given } \\
\text { off by the sample, indicating the complete } \\
\text { reaction. Allow the solution to evaporate to } \\
\text { approximately } 25 \text { mL without boiling or heat at } \\
95^{\circ} \mathrm{C} \pm 5^{\circ} \mathrm{C} \text { without boiling for two hours. } \\
\text { Remove the acid extract after solids settle. }\end{array}$ \\
\hline \multicolumn{4}{|c|}{ Wash 15 minutes with $15 \mathrm{~mL}$ DI and add to nitric acid } \\
\hline Bulk Powder & $\mathrm{XRF}$ & $\begin{array}{l}\text { Residuals (quartz, } \\
\text { etc.) }\end{array}$ & Oven dry to get weight left; crush for XRF \\
\hline
\end{tabular}




\subsection{Data Management}

A project-specific database will be developed and maintained to collect, organize, store, verify/validate, and manage analytical laboratory data and/or field measurements for environmental samples. The data will be stored electronically in Microsoft Excel spreadsheets and paper copies will be maintained in the project files. A project data custodian will be designated to control and maintain the data. The following data will be contained, at a minimum, as part of the database:

- Sample identifier.

- Sample location.

- Sample medium type.

- Sampling date.

- Analysis date.

- Laboratory name.

- Analyte name.

- Concentration value.

- Measurement unit.

Data will be managed in accordance with the EM-20 project QA plan (PNNL 2007). 


\subsection{Health and Safety}

Safety and health issues relating to the treatability test are addressed in site-specific safety documents that identify both radiological and industrial safety and health hazards as well as control measures for those hazards. Safety documents include specific training requirements for all site workers as well as visitors. Job-specific health and safety plans covering drilling activities will be prepared by Fluor Hanford, Inc. personnel. PNNL will develop a project specific health and safety plan(s) covering field testing activities associated with the Uranium Stabilization through Polyphosphate Injection Treatability Study. 


\subsection{Quality Assurance}

The work will comply with applicable subject areas of the PNNL SBMS. SBMS is a web-based system for communicating PNNL's management systems and procedures through subject areas. PNNL's Quality Assurance Program is based on the requirements of DOE Order 414.1C, Quality Assurance, and 10 CFR 830, Subpart A, Quality Assurance Requirements. Additional specific QA requirements are provided in the EM-20 project QA plan (PNNL 2007). 


\subsection{Waste Management}

All investigation-derived waste (IDW) will be handled in accordance with PNNL waste management procedures and applicable Hanford Site requirements. Expected waste streams may include the following:

- Miscellaneous solid waste such as filters, wipes, gloves and other personal protective equipment, cloth, sampling and measuring equipment, pumps, pipe, wire, or plastic sheeting.

- Purge water generated during groundwater sampling and hydraulic testing.

- Decontamination solutions.

Miscellaneous solid waste that has contacted potentially contaminated groundwater will be segregated from other materials and will be transported to PNNL facilities for disposal based on a waste designation per internal PNNL waste management procedures. Waste will be designated in accordance with WAC 173-303 using a combination of process knowledge, historical analytical data, and analyses of samples collected from the site.

Based on historical data from nearby monitoring well 399-1-17 and baseline data from site monitoring wells, the hazardous waste designation for total uranium $(0.2 \mu \mathrm{g} / \mathrm{L})$, which is the only constituent identified in local groundwater plumes likely to trigger a hazardous waste designation, is likely to be exceeded and thus, all investigation derived sampling waste will be disposed of in accordance with PNNL procedures for disposal of such waste. All generated purge water and decontamination water will be handled in accordance with Hanford Site requirements.

Spill Containment/Control. The polyphosphate amendment solution (see Table 2.7) will arrive on site via tanker trucks. A walk down of the truck will be initiated prior to acceptance of the tank for any leak points. After the tanker is accepted, the tanker will be positioned in the designated locations. An inventory of spill cleanup equipment and materials shall be maintained on site. These will include shovels, absorbents, containers, plastic bags, wipes, and large plastic sheets or tarps. Should a leak occur after acceptance of the tanker, the PNNL field lead engineer or PNNL technical representative shall be notified and measures shall be taken to remedy the leak and minimize the spill as practical.

Spill Control and Containment Supplies. Table 11.1 lists spill kits and spill control equipment that will be maintained at the field test site.

Table 11.1. Spill Kits and Spill Control Equipment

\begin{tabular}{||c|c|c||}
\hline Type & Location & Capability \\
\hline \hline Absorbent & Inside spill-control drum & Absorb small quantity spills \\
\hline Plastic bags and tape & Inside spill control drum & Collection of material \\
\hline Plastic sheet or tarp & PNNL laboratory trailer & Used for containment \\
\hline
\end{tabular}




\subsection{NEPA Values}

In accordance with DOE Order 451.1 and the National Environmental Policy Act (NEPA), DOE CERCLA documents are to incorporate NEPA values to the extent practicable. NEPA values, such as analysis of cumulative offsite ecological and socioeconomic impacts; description of the affected environment (including meteorology, hydrology, geology, cultural and ecological resources, and land use); short-term and long-term impacts on human health and the environment; emissions to air and water; and cost are typically included in CERCLA feasibility study. Compliance with ARARs for this treatability test is discussed in Section 4.

NEPA values specific to the polyphosphate treatability test include the following:

- Cultural and ecological resources reviews were performed in the area where the in situ test is to occur. Because this area has been previously disturbed, no cultural resources are reported or anticipated with the project area.

- Particulate releases to the atmosphere would be limited to fugitive dust emissions that might occur as a result of the proposed activities (e.g., movement of vehicles and equipment). The Columbia River is located approximately $350 \mathrm{~m}(1,148 \mathrm{ft})$ from the proposed the test area; reasonable care in activities will minimize the chance of the river becoming a consequential pathway for particulates.

- Droplet releases might result from the use of uncontaminated water, which would be applied as necessary to mitigate dust during the well installations and construction of the polyphosphate test.

- Removal, storage, and disposal of waste would be in accordance with applicable federal and state regulations and guidelines and would not impact employees or the environment.

- The proposed activity will be conducted within the upper unconfined aquifer beneath the Hanford 300 Area. The targeted subsurface interval consists of unconsolidated gravel-dominated sediments of the Hanford formation unit 1 and is contaminated with uranium at levels above drinking water standards $(30 \mu \mathrm{g} / \mathrm{L})$.

- The proposed activity is less than $0.4 \mathrm{~km}$ from the Columbia River. The Hanford Reach Study Act requires notification of the National Park Service of the U.S. Department of the Interior if the project is to be conducted within $0.4 \mathrm{~km}(2.48 \mathrm{~m})$ of the Columbia River. However, because this site is located well south of the Hanford Reach National Monument boundary, this regulation will not apply and notification or approval from the U.S. Fish and Wildlife Service will not be required.

- The polyphosphate project represents a small fraction of the total Hanford Site budget. Therefore, the project is not expected to impact socioeconomics of the Tri-Cities or other parts of Benton and Franklin Counties.

- The project staff and materials associated with the polyphosphate project would not significantly impact transportation in the area. 


\subsection{Reports}

A test report summarizing the results of the treatability test will be prepared. The format of the report will be based on the suggested outline for treatability test reports provided in the Guide for Conducting Treatability Studies Under CERCLA (EPA 1992). This report will be provided to DOE and the regulatory agencies at the completion of the project. Following is a general outline of the treatability test report.

\subsection{Introduction}

1.1 Site Description

1.2 Background

1.3 Treatment Technology Description

2.0 Treatability Study Approach

2.1 Treatability Test Objectives

2.2 Conceptual Design

2.3 Equipment and Material

2.4 Sampling and Analysis

2.5 Data Management

3.0 Treatability Study Activities

3.1 Bench-Scale Testing

3.2 Site Specific Characterization

3.3 Injection Design Analysis

3.4 Polyphosphate Injection Test

4.0 Results and Discussion

4.1 Data Analysis and Interpretation

4.2 Treatment Effectiveness and Longevity

4.3 Implementation challenges

4.4 Comparison with Test Objectives

4.5 Cost/Schedule for Performing Treatability Study

5.0 Conclusions and Recommendations 


\subsection{Schedule}

The schedule of project activities associated with the field test is shown in Figure 14.1.

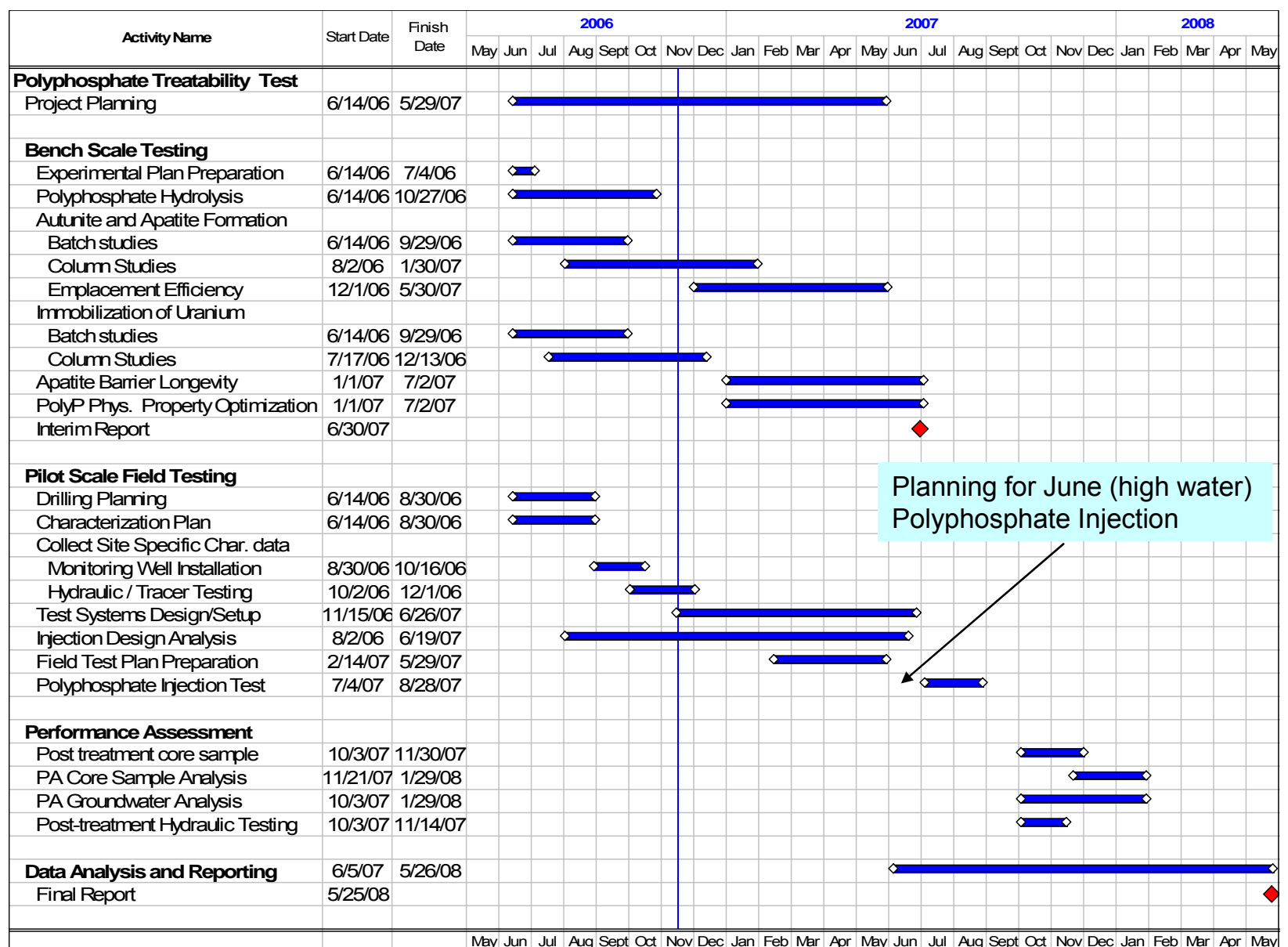

Figure 14.1. Schedule of Field Test Activities 


\subsection{References}

10 CFR 830, Subpart A. “Quality Assurance Requirements.” Code of Federal Regulations, U.S. Department of Energy.

40 CFR 122. "EPA Administered Permit Programs: The National Pollutant Discharge Elimination System." Code of Federal Regulations, U.S. Environmental Protection Agency.

40 CFR 131.36. "Water Quality Standards; Toxics Criteria for those States not Complying with Clean Water Act Section 303(c)(2)(B)." Code of Federal Regulations, U.S. Environmental Protection Agency.

40 CFR 300.400. "National Oil and Hazardous Substances Pollution Contingency Plan; General." Code of Federal Regulations, U.S. Environmental Protection Agency.

Amjad Z, PG Koutsoukos, and GH Nancollas. 1981. "Crystallization of Fluoroapatite. A Constant Composition Study.” Journal of Colloid and Interface Science 82(2), 394-400.

Arey JS, JC Seaman, and PM Bertsch. 1999. "Immobilization of Uranium in Contaminated Sediments by Hydroxyapatite Addition.” Environmental Science and Technology 33:337-342.

ASME. 1989. NQA-1 - 1989 Quality Assurance Program Requirements for Nuclear Facilities. American Society of Mechanical Engineers, New York, New York.

Avrami M. 1939. "Kinetics of Phase Change, I." Journal of Chemistry and Physics 7:1103-1112.

Avrami M. 1940. “Kinetics of Phase Change, II.” Journal of Chemistry and Physics 8:212-224.

Bald and Golden Eagle Protection Act. 1992. Public Law 87-884, as amended, 76 Stat. 1246, 16 USC 688 et seq.

Boskey AL and AS Posner. 1973. "Conversion of Amorphous Calcium Phosphate to Microcrystalline Hydroxyapatite. A pH-Dependent, Solution-Mediated, Solid-Solid Conversion." Journal of Physics and Chemistry 77:2313-2317.

Boskey AL and AS Posner. 1976. "Formation of Hydroxyapatite at Low Supersaturation." Journal of Physics and Chemistry 80:40-45.

Bouwer H. 1989. “The Bouwer and Rice Slug Test - An Update.” Ground Water 27(3):304-309.

Brown JL. 1980. "Calcium Phosphate Precipitation in Aqueous Calcite Limestone Suspensions." Journal of Environmental Quality 9(4):641-644.

Brown JL. 1981a. "Calcium Phosphate Precipitation: Effect of Common and Foreign Ions on Hydroxyapatite Crystal Growth.” Soil Science Society of America Journal 45:482-486.

Brown JL. 1981b. "Calcium Phosphate Precipitation: Identification of Kinetic Parameters in Aqueous Limestone Suspensions.” Soil Science Society of America Journal 45:475-477. 
Brown WE, JP Smith, JR Lehr, and AW Frazier. 1962. "Crystallographic and Chemical Relations between Octacalcium Phosphate and Hydroxyapatite.” Nature 196(4859):1050.

Christoffersen J and MR Christoffersen. 1982. "Kinetics of Dissolution of Calcium Hydroxyapatite: V. The Acidity Constant for the Hydrogen Phosphate Surface Complex." Journal of Crystal Growth $57: 21-26$.

Comprehensive Environmental Response, Compensation, and Liability Act. 1980. Public Law 96-510, as amended, 94 Stat. 2767, 42 USC 9601 et seq.

Conca JL. 1996. "Phosphate-Induced Metal Stabilization.” In S.t.A.R.S. Program, National Center for Environmental Research, Office of Research and Development, U.S. Environmental Protection Agency, Washington, D.C.

Diaz OA, KR Reddy, and PA Moore, Jr. 1994. "Solubility of Inorganic Phosphorous in Stream Water as Influenced by $\mathrm{pH}$ and Calcium Concentration.” Water Resources 28(8):1755-1763.

DOE. 1995. Remedial Investigation/Feasibility Study Report for the 300-FF-5 Operable Unit.

DOE/RL-94-85, U.S. Department of Energy, Richland, Washington.

DOE. 2005. Work Plan for Phase III Feasibility Study, 300-FF-5 Operable Unit. DOE/RL-2005-41, Rev. 0, March 2005. Prepared by Pacific Northwest National Laboratory for the U.S. Department of Energy, Richland, Washington.

DOE. 2006. 300-FF-5 Operable Unit Limited Field Investigation Plan. DOE/RL-2005-47, Rev. 1, U.S. Department of Energy, Richland, Washington.

DOE Order 414.1C. "Quality Assurance."

DOE Order 451.1. "National Environmental Policy Act Compliance Program."

Eanes ED and JL Meyer. 1977. Maturation of Crystalline Calcium Phosphates in Aqueous Suspensions at Physiologic Ph." Calcareous Tissue Research 23(3):259.

Eanes ED and AS Posner. 1965. "Kinetics and Mechanism of Conversion of Noncrystalline Calcium Phosphate to Crystalline Hydroxyapatite." Transactions New York Academy of Sciences, p. 233-240, New York.

Eanes ED and AS Posner. 1970. "A Note on the Crystal Growth of Hydroxyapatite Precipitated from Aqueous Solutions." Materials Research Bulletin 5(6):377-384.

Eanes ED, IH Gillessen, and AS Posner. 1965. "Intermediate States in the Precipitation of Hydroxyapatite." Nature 208:365-367.

Ecology, EPA, and DOE. 1989, as revised. Hanford Federal Facility Agreement and Consent Order. Washington State Department of Ecology, U.S. Environmental Protection Agency, and U.S. Department of Energy, Olympia, Washington. 
Endangered Species Act. 1973. Public Laws 93-205 through 100-707, as amended, 87 Stat. 884, 16 USC 1531 et seq.

EPA. 1991. "Method 300.0. The Determination of Inorganic Anions in Water by Ion Chromatography. U.S. Environmental Protection Agency, Washington, D.C.

EPA. 1992. Guide for Conducting Treatability Studies Under CERCLA. Final Rule, EPA/540/R92/071a, U.S. Environmental Protection Agency, Washington, D.C.

EPA. 1996a. Record of Decision for USDOE Hanford 300-FF-1 and 300-FF-5 Operable Units Remedial Actions. EPA/ROD/R10-96/143, U.S. Environmental Protection Agency, Region 10, Seattle, Washington.

EPA. 1996b. "Method 6010B. Inductively Coupled Plasma-Atomic Emission Spectrometry." In Test Methods for Evaluating Solid Waste, Physical/Chemical Methods. Publication SW-846, U.S. Environmental Protection Agency, Washington, D.C. Available at http://www.epa.gov/epaoswer/hazwaste/test/sw846.htm

EPA. 2000. "Method 6020. Inductively Coupled Plasma-Mass Spectrometry." In Test Methods for Evaluating Solid Waste, Physical/Chemical Methods. Publication SW-846, U.S. Environmental Protection Agency, Washington, D.C. Available at http://www.epa.gov/epaoswer/hazwaste/test/sw846.htm

Fayer MJ and TB Walters. 1995. Estimated Recharge Rates at the Hanford Site. PNL-10285, Pacific Northwest Laboratory, Richland, Washington.

Feenstra TP and PL de Bruyn. 1979. "Formation of Calcium Phosphates in Moderately Supersaturated Solutions." Journal of Physical Chemistry 83(4):475-479.

Ferguson JF, D Jenkins, and J Eastman. 1973. "Calcium Phosphate Precipitation at Slightly Alkaline $\mathrm{pH}$ Values." Water Pollution Control Federation 45(4):620-631.

Ferguson JF, D Jenkins, and W Stumm. 1970. "Calcium Phosphate Precipitation in Wastewater Treatment." Chemical Engineering Progress Symposium Series 107(67):279-287.

Fuller CC, JR Bargar, JA Davis, and MJ Piana. 2002a. "Mechanisms of Uranium Interactions with Hydroxyapatite: Implication for Groundwater Remediation." Environmental Science and Technology 36:158-165.

Fuller CC, MJ Piana, JR Bargar, JA Davis, and M Kohler. 2002b. "Evaluation of Apatite Materials for Use in Permeable Reactive Barriers for the Remediation of Uranium-Contaminated Groundwater." In Handbook of Groundwater Remediation Using Permeable Reactive Barriers: Applications to Radionuclides, Trace Metals, and Nutrients. DL Naftz, SJ Morrison, JA Davis and CC Fuller (eds.), Academic Press, San Diego, California.

Fuller CC, JR Bargar, and JA Davis. 2003. "Molecular-Scale Characterization of Uranium Sorption by Bone Apatite Materials for a Permeable Reactive Barrier Demonstration." Environmental Science and Technology 37:4642-4649. 
Gamerdinger AP, DI Kaplan, DM Wellman, and RJ Serne. 2001a. "Two-Region Flow and Decreased Sorption of Uranium (VI) during Transport in Hanford Groundwater and Unsaturated Sands." Water Resources Research 37(12):3155-3162.

Gamerdinger AP, DI Kaplan, DM Wellman, and RJ Serne. 2001b. Two-Region Flow and Decreased Sorption of Uranium (VI) during Transport in an Unsaturated Silt Loam." Water Resources Research 37(12):3147-3153.

Gamerdinger AP, K van Rees, PSC Rao, and RE Jessup. 1994. "Evaluation of In Situ Columns for Characterizing Organic Contaminant Sorption during Transport." Environmental Science and Technology 28:376-382.

Garten VA and RB Head. 1966. "Homogeneous Nucleation and the Phenomenon of Crystalloluminescence." Philosophical. Magazine 14(132):1243.

Gauglitz R and M Holterdorf. 1992. "Immobilization of Heavy Metals by Hydroxyapatite." Radiochimica Acta 58(59):253-257.

Gee GW and D Orr. 2002. "Particle-Size Analysis." In Methods of Soil Analysis, Part 4-Physical Methods. JH Dane and GC Topp (eds.), Soil Sci. Am. Book Series: 5.

Griffith EJ, A Beeton, JM Spencer, and DT Mitchell. 1973. Environmental Phosphorus Handbook. John Wiley \& Sons, New York.

Hanford Reach Study Act. 1988. Public Law 100-605, 102 Stat. 3043.

HAPO. 1953. Process Specifications, Reactor Cooling Water Treatment. HW-28505, July 15, 1953, Hanford Atomic Products Operation, General Electric Company, Richland, Washington.

Hartman MJ, LF Morasch, and WD Webber (eds.). 2007. Hanford Site Groundwater Monitoring for Fiscal Year 2006. PNNL-16346, Pacific Northwest National Laboratory, Richland, Washington.

Hoopes JA and DRF Harleman. 1967. "Dispersion in Radial Flow from a Recharge Well." Journal of Geophysical Research 72:3595-3607.

Inskeep WP and JC Silvertooth. 1988. "Kinetics of Hydroxyapatite Precipitation at pH 7.4 to 8.4." Geochimica et Cosmochimica Acta 52:1883-1893.

Jenkins D, JF Ferguson, and AB Menar. 1971. "Chemical Processes for Phosphate Removal." Water Research 5:369-389.

Jensen MP, K Nash, JW Morse, EH Appelman, and MA Schmidt. 1996. Immobilization of Actinides in Geomedia by Phosphate Precipitation. ACS Symposium Series \#651, p. 272-285.

Lee SY, CW Francis, ME Timpson, and MP Elless. 1995. Radionuclide Containment in Soil by Phosphate Treatment. Oak Ridge National Laboratory, Oak Ridge, Tennessee. 
Lindberg JW and FW Bond. 1979. Geohydrology and Ground-Water Quality Beneath the 300 Area, Hanford Site, Washington. PNL-2949, Pacific Northwest Laboratory, Richland, Washington.

Lindsay WL. 1979. "Phosphates.” In Chemical Equilibria in Soils, JW Sons (ed.), p. 163-209. The Blackburn Press, Caldwell, New Jersey.

Lindsay WL and EC Moreno. 1960. "Phosphate Phase Equilibria in Soils." Soil Science Society of America Proceedings 24:177-182.

Migratory Bird Treaty Act. 1918. Chapter 128, as amended, 40 Stat. 755, 16 USC 703-712.

Moore RC, C Sanchez, J Schelling, J Jones, DR Anderson, F Salas, D Lucero, and K Holt. 2001. BenchScale Testing of In-Situ Formation of Apatite in Hanford Soils for Sorption of Uranium and Technetium. Sandia National Laboratories, Albuquerque, New Mexico.

Murakami T, H Isobe, T Sato, and T Ohnuki. 1996. "Weathering of Chlorite in a Quartz-Chlorite Schist I. Mineralogical and Chemical Changes." Clays and Clay Minerals 44(2):244-256.

Nancollas GH and MS Mohan. 1970. "The Growth of Hydroxyapatite Crystals." Archieves of Oral Biology 15:731-745.

Nancollas GH and BB Tomazic. 1974. "Growth of Calcium Phosphate on Hydroxyapatite Crystals. Effect of Supersaturation and Ionic Medium.” Journal of Physics and Chemistry 78:2218-2225.

Nash K. 2000. Organophosphorous Reagents in Actinide Separations: Unique Tools for Production, Cleanup and Disposal. Argonne National Laboratory, Argonne, Illinois.

Nash K, MP Jensen, and MA Schmidt. 1997. "Actinide Immobilization in the Subsurface Environment by In-Situ Treatment with a Hydrolytically Unstable Organophosphorous Complexant: Uranyl Uptake by Calcium Phytate.” International Conference on Actinides, Baden-Baden, Germany.

Nash K, EJ Jensen, and MA Schmidt. 1998a. "In-Situ Actinide Immobilization of Actinides for Groundwater Cleanup: Laboratory Demonstration with Soil from the Fernald Environmental Management Project." In Science and Technology for Disposal of Radioactive Tank Wastes, WW Schultz, and NJ Lombardo (eds.), p. 507-518. Plenum Press, New York.

Nash K, MP Jensen, and MA Schmidt. 1998b. Actinide Immobilization in the Subsurface Environment by In-Situ Treatment with a Hydrolytically Unstable Organophosphorous Complexant: Uranyl Uptake by Calcium Phytate." Journal of Alloys and Compounds 271-273:257-261.

Nash K, LR Morse, MP Jensen, EH Appelman, MA Schmidt, S Friedrich, M Redko, and JJ Hines. 1999. Water-Soluble Organophosphorous Reagents for Mineralization of Heavy Metals. Argonne National Laboratory, Argonne, Illinois.

National Archeological and Historical Preservation Act. 1974. 16 USC 461, et seq.

National Historic Preservation Act. 1966. Public Law 89-665, as amended, 16 USC 470 et seq. 
Nriagu JO and PB Moore. 1984. Phosphate Minerals. Spinger-Verlag, Berlin, Germany.

Patton GP, BL Tiller, EJ Antonio, TM Poston, and SP Van Verst. 2003. Survey of Radiological and Chemical Contaminants in the Near-Shore Environment at the Hanford Site 300 Area. PNNL-13692, Rev. 1, Pacific Northwest National Laboratory, Richland, Washington.

Peterson RE (ed.), EJ Freeman, CJ Murray, RE Peterson, PD Thorne, MJ Truex, VR Vermeul, MD Williams, SB Yabusaki, JM Zachara, JL Lindberg, and JP McDonald. 2005. Contaminants of Potential Concern in the 300-FF-5 Operable Unit: Expanded Annual Groundwater Report for FY 2004. PNNL-15127, Pacific Northwest National Laboratory, Richland, Washington.

PNNL. 1994, as revised. Procedures for Ground-Water Investigations. PNL-MA-567, Pacific Northwest National Laboratory, Richland, Washington.

PNNL. 2007. The Columbia River Protection Supplemental Technologies Quality Assurance Project Plan. PNNL-16340, Pacific Northwest National Laboratory, Richland, Washington.

Rasmussen TC and LA Crawford. 1997. "Identifying and Removing Barometric Pressure Effects in Confined and Unconfined Aquifers." Ground Water 35(3):502-511.

Reidel SP, KA Lindsey, and KR Fecht. 1992. Field Trip Guide to the Hanford Site. WHC-MR-0391, Westinghouse Hanford Company, Richland, Washington.

Resource Conservation and Recovery Act. 1976. Public Law 94-580, as amended, 90 Stat. 2795, 42 USC 6901 et seq.

Rockhold ML, MJ Fayer, and GW Gee. 1988. Characterization of Unsaturated Hydraulic Conductivity at the Hanford Site. PNL-6488, Pacific Northwest Laboratory, Richland, Washington.

Rockhold ML MJ Fayer, CT Kincaid, and GW Gee. 1995. Estimation of Natural Ground Water Recharge for the Performance Assessment of a Low-Level Waste Disposal Facility at the Hanford Site. PNL-10508, Pacific Northwest National Laboratory, Richland, Washington

Schalla R, RW Wallace, RL Aaberg, SP Airhart, DJ Bates, JVM Carlile, CS Cline, DI Dennison, MD Freshley, PR Heller, EJ Jensen, KB Olsen, RG Parkhurst, JT Rieger, and EJ Westergard. 1988. Interim Characterization Report for the 300 Area Process Trenches. PNL-6716, Pacific Northwest Laboratory, Richland, Washington.

Schmid LA and RR McKinney. 1968. Phosphate Removal by a Lime-Biological Treatment Scheme. Water Pollution Control Federation, Chicago, Illinois.

Seaman JC, JS Arey, and PM Bertsch. 2001. "Immobilization of Nickel and Other Metals in Contaminated Sediments by Hydroxyapatite Addition." Journal of Environmental Quality 30:460-469.

Serne RJ, CF Brown, HT Schaef, EM Pierce, MJ Lindberg, Z Wang, P Gassman, and J Catalano. 2002. 300 Area Uranium Leach and Adsorption Project. PNNL-14022, Pacific Northwest National Laboratory, Richland, Washington. 
Shen CY and FW Morgan. 1973. "Hydrolysis of Phosphorous Compounds." In Environmental Phosphorous Handbook, EJ Griffith, A Beeton, JM Spencer, and DT Mitchell (eds.), p. 241. John Wiley \& Sons, New York.

Spane FA. 2002. "Barometric Pressure in Groundwater Flow Investigations." Water Resources Research 38(6)14:1-18.

Sparks DL and S Hunger. 2002. Mechanisms of Phosphorus Stabilization in the Soil Environment: A Molecular Scale Evaluation, p. 1-20. University of Delaware, Newark, New Jersey.

Swanson LC, GG Kelty, KA Lindsey, KR Simpson, RK Price, and SD Consort. 1992. Phase 1 Hydrogeologic Summary of the 300-FF-5 Operable Unit, 300 Area. WHC-SD-EN-TI-052, Rev. 0, Westinghouse Hanford Company, Richland, Washington.

Termine JD, RA Peckauskas, and AS Posner. 1970. "Calcium Phosphate Formation In Vitro II. Effects of Environment on Amorphous-Crystalline Transformation." Archieves of Biochemistry and Biophysics 140:318-325.

Termine JD and AS Posner. 1970. "Calcium Phosphate Formation In Vitro I. Factors Affecting Initial Phase Separation.” Archieves of Biochemistry and Biophysics 140:307-317.

Tessier A, PGC Campbell, and M Blsson. 1979. "Sequential Extraction Procedure for the Speciation of Particulate Trace Metals.” Analytical Chemistry 51(7):844-851.

van Cappellen P and RA Berner. 1991. "Fluorapatite Crystal Growth from Modified Seawater Solutions." Geochimica et Cosmochimica Acta 55:1219-1234.

Vermeul VR, JS Fruchter, DM Wellman, BA Williams, and MD Williams. 2006. Site Characterization Plan: Uranium Stabilization through Polyphosphate Injection. PNNL-16008, Pacific Northwest National Laboratory, Richland, Washington.

WAC 173-160. "Minimum Standards for Construction and Maintenance of Wells." Washington Administrative Code, Olympia, Washington.

WAC 173-200. "Water Quality Standards for Ground Waters of the State of Washington." Washington Administrative Code, Olympia, Washington.

WAC 173-201A. "Water Quality Standards for Surface Water of the State of Washington." Washington Administrative Code, Olympia, Washington.

WAC 173-218. "Underground Injection Control Program.” Washington Administrative Code, Olympia, Washington.

WAC 173-303. "Dangerous Waste Regulations.” Washington Administrative Code, Olympia, Washington.

WAC 173-304. "Minimum Functional Standards for Solid Waste Handling." Washington Administrative Code, Olympia, Washington. 
WAC 232-12-292. "Bald Eagle Protection Rules.” Washington Administrative Code, Olympia, Washington.

Wellman DM, JP Icenhower, and AT Owen. 2006. "Comparative Analysis of Soluble Phosphate Amendments for the Remediation of Heavy Metal Contaminants: Effect on Sediment Hydraulic Conductivity." Environmental Chemistry 3:219-224.

Wellman DM, JI Icenhower, EM Pierce, BK McNamara, SD Burton, KN Geiszler, SR Baum, and BC Butler. 2005. "Polyphosphate Amendments for In Situ Immobilization of Uranium Plumes." In Third International Conference on Remediation of Contaminated Sediments, RF Olfenbuttel and PJ White (eds.), Battelle Press, New Orleans, Louisiana.

White MD and M Oostrom. 2000. STOMP Subsurface Transport Over Multiple Phase: Theory Guide. PNNL-11216, Pacific Northwest National Laboratory, Richland, Washington.

White MD and M Oostrom. 2006. STOMP Subsurface Transport Over Multiple Phases, Version 4.0, User's Guide. PNNL-15782, Pacific Northwest National Laboratory, Richland, Washington.

Williams BA. 2007. Borehole Data Package for Nine CY 2006 Polyphosphate Treatability Testing Wells, 300-FF-5 Operable Unit, Hanford Site, Washington. PNNL-16522, Pacific Northwest National Laboratory, Richland, Washington.

Williams BA, BN Bjornstad, DC Lanigan, JM Keller, and ML Rockhold. 2006. Borehole Data Package for One CY2005 CERCLA Well 699-S20-E10, 300-FF-5 Operable Unit, Hanford Site, Washington. PNNL-15417, Pacific Northwest National Laboratory, Richland, Washington.

Williams BA, CF Brown, W Um, MJ Nimmons, RE Peterson, BN Bjornstad, RJ Serne, FA Spane, and ML Rockhold. 2007. Limited Field Investigation Report for Uranium Contamination in the 300 Area, 300-FF-5 Operable Unit, Hanford Site, Washington. PNNL-16435, Pacific Northwest National Laboratory, Richland, Washington.

Wright J, LM Peurrung, TE Moody, JL Conca, X Chen, PP Didzerekis, and E Wyse. 1995. In Situ Immobilization of Heavy Metals in Apatite Mineral Formulations. Pacific Northwest Laboratory, Richland, Washington.

Zachara JM, JA Davis, C Liu, JP McKinley, N Qafoku, DM Wellman, and SB Yabusaki. 2005. Uranium Geochemistry in Vadose Zone and Aquifer Sediments from the 300 Area Uranium Plume. PNNL-15121, Pacific Northwest National Laboratory, Richland, Washington.

Zurbuchen BR, VA Zlotnik, and JJ Butler, Jr. 2002. "Dynamic Interpretation of Slug Tests in Highly Permeable Aquifers." Water Resources Research 38(3) 7:1-18. 


\section{Distribution}

No. of

Copies

2 DOE Richland Operations Office

DOE Public Reading Room (2) H2-53

Fluor Hanford, Inc.

5 Pacific Northwest National Laboratory

JS Fruchter K6-96

VR Vermeul K6-96

DA Wellman K3-62

Hanford Technical Library (2) P8-55 